$$
\text { cesore }
$$




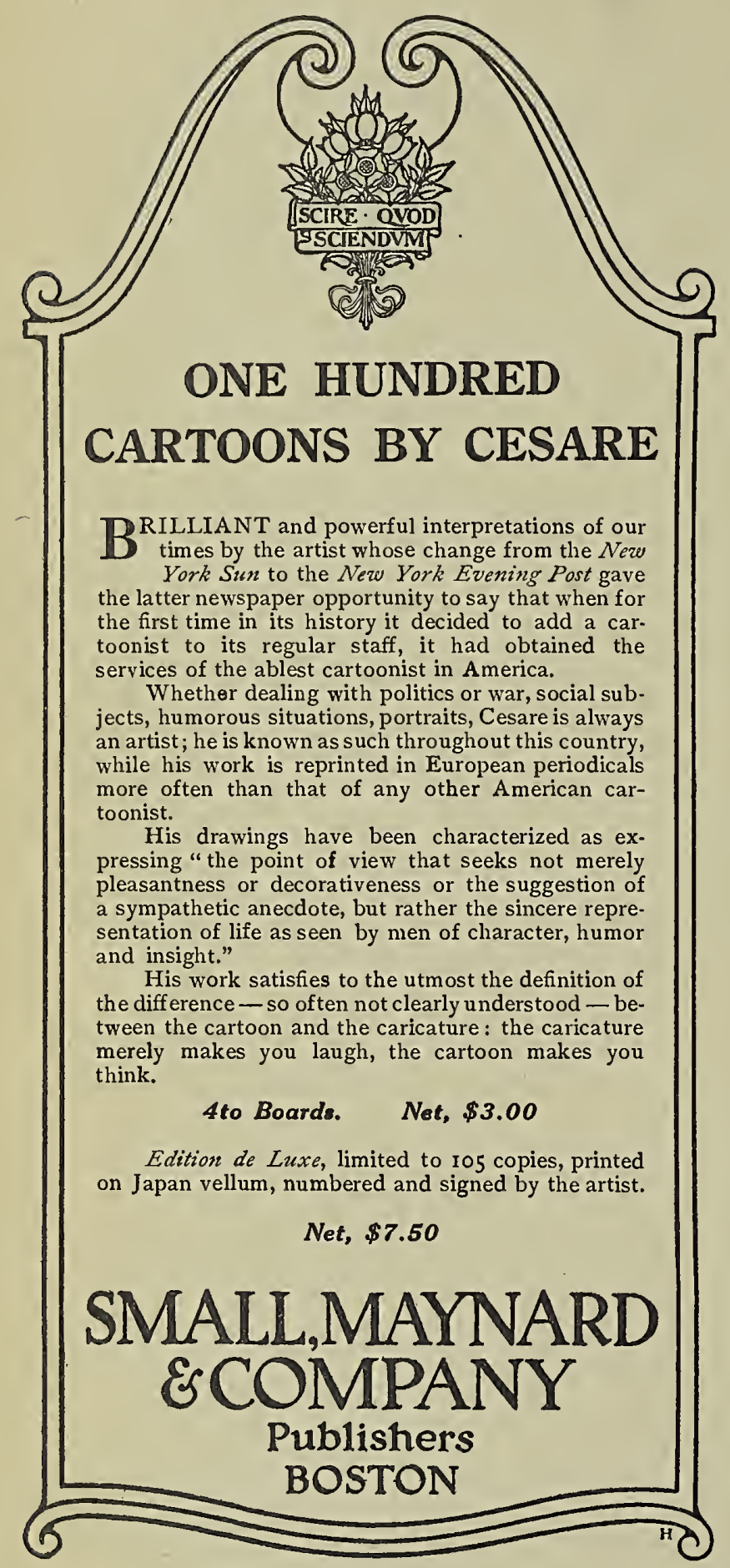








\section{ONE HUNDRED}

CARTOONS BY CESARE 




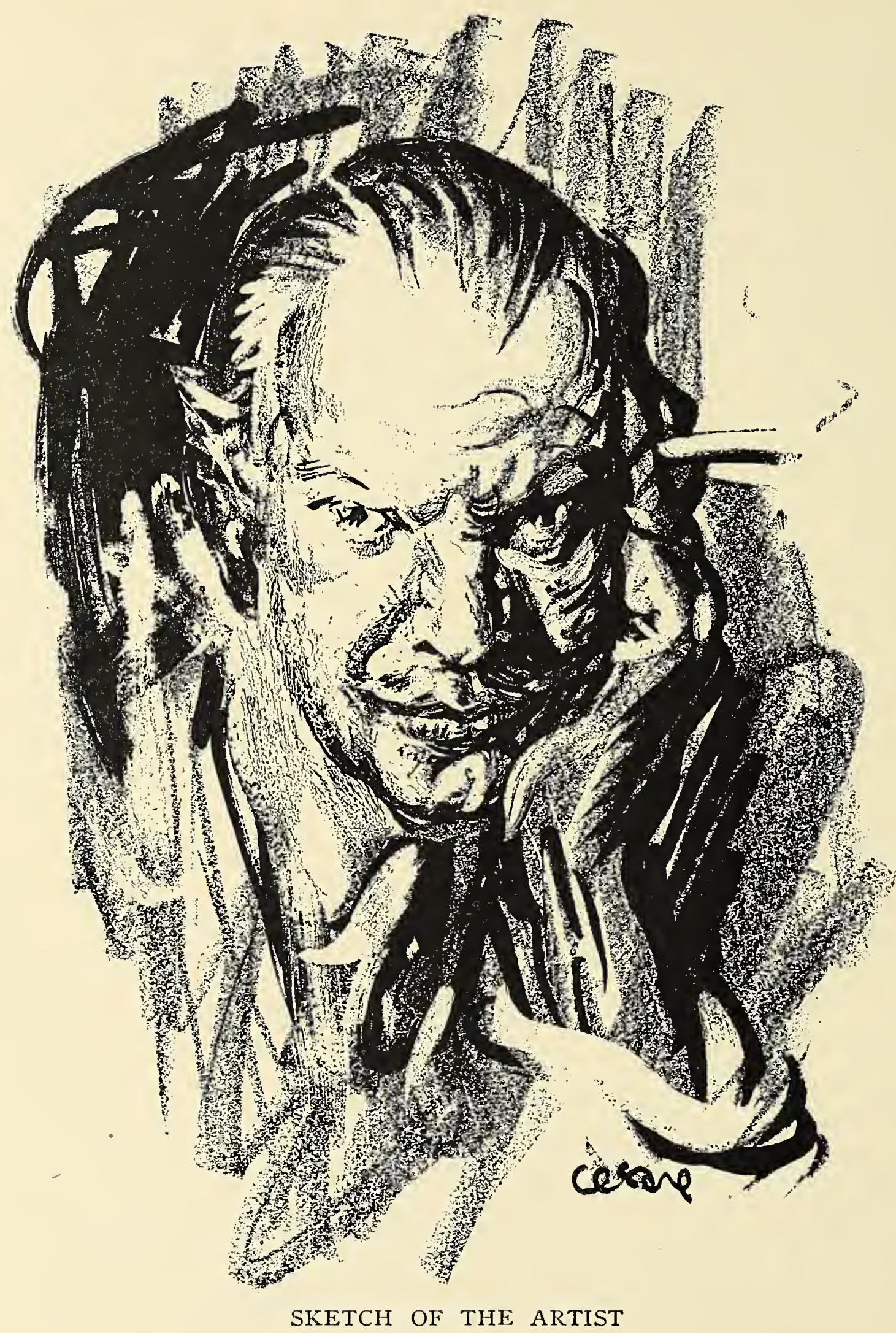

BX HIMSELF 


\section{ONE HUNDRED}

\section{GARTOONS BY CESARE}

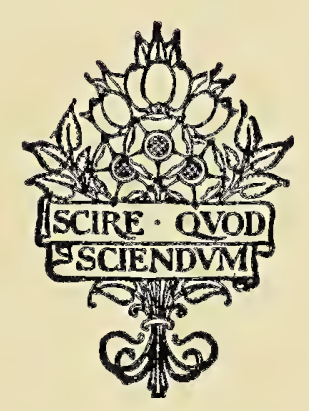

BOSTON

Small, Maynard \& Company

MCMXVI 
Copyright, 1916

By SMALL, MAYNARD \& COMPANY

(Incorporated)

积riutern

S. J. Parkhill \& Co., Boston, U.S.A. 
M. P. C. 
GRATEFUL ACKNOWLEDGMENT IS MADE TO THE EDITORS OF THE NEW YORK SUN AND OF HARPER'S WEEKLY FOR PERMISSION TO REPRINT HERE DRAWINGS THAT FIRST APPEARED IN THOSE PUBLICATIONS 


\section{LIST OF ILLUSTRATIONS}

SKETCH OF THE ARTIST, BY HIMSELF

PAGE

THEY ARE ALL RED TO HIM

"What have you done With your brother Abel?" . . . . . . . . 3

The Kaiser: “My heart bleeds For Antwerp, too" . . . . . . 5

THE HONORABle Ally

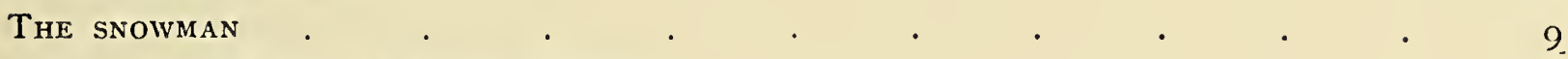

A great disaster. A great Victory - . . . . . . . . . . . i i

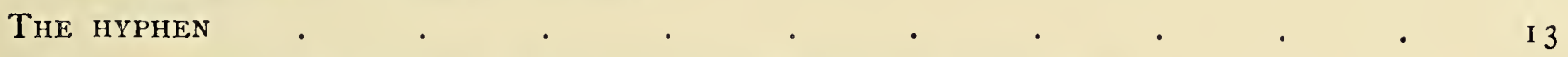

Lloyd Geokge, Minister of Munitions : "England expects - " . . . 15

To-morRow's GUide: “These are the RUins of William the Second” . . . I7

WAR'S EDICT

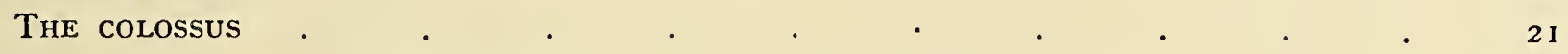

ChRISTMAS MORNING

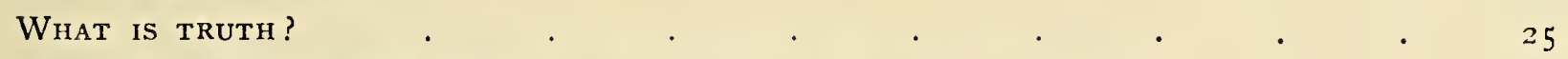

"By the beard of the Prophet, our future lies in the Eastl" . . 27

Playful . $\quad$. $\quad$. $\quad$.

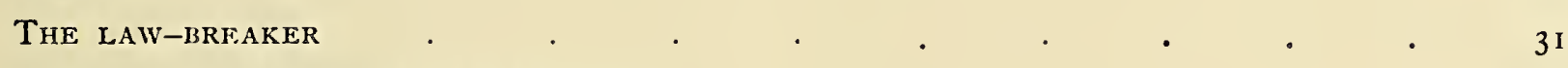

WASHington's BirthDAY: I732-1915 . . . . . . . . . . . 33

Tirpitz: "Dreadful! Too ban!" . . . . . . . . . . . . . . . 35

THE WASH

Peace .

ResURRETED .

THE GREAT ALLY

WHO SAID SICK?

"How happy COUld I be With Neither - . . . . . . . . . . . . 47

THE FURROW

The Sublime Port

THE STORM

HALTED . . . . . . . . . . . . . . . . 55

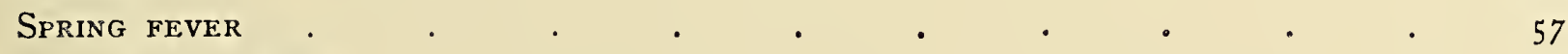

OUT OF THE DEPTHS

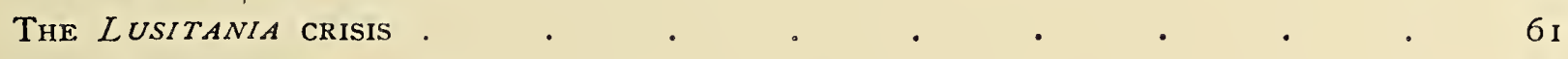

Cold AS THE ICEBERG .

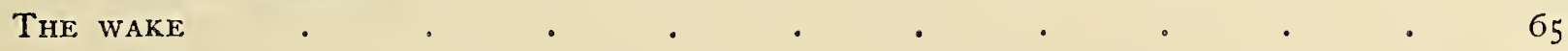


The fifth Circle of Hell . . . . . . . . . . . . . . . . 67

War staggered: “What crimes are Committed in my name!” . . . . 69

The octopus .

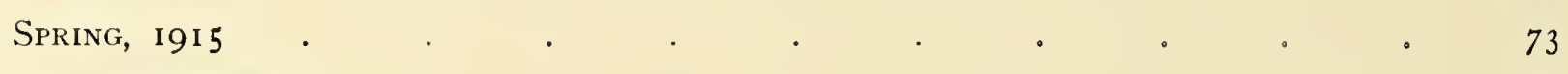

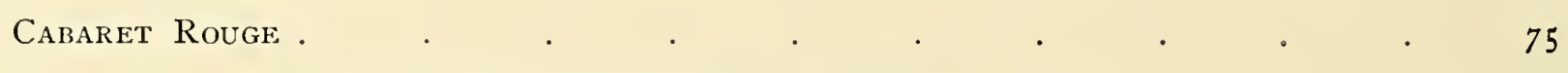

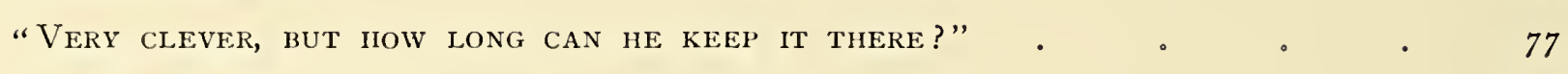

Cease firing!

THE SPIRIT OF ' 48 .

NO MERCY

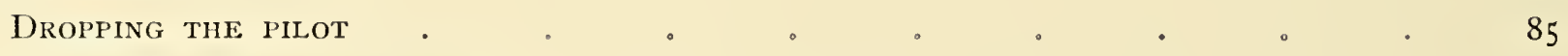

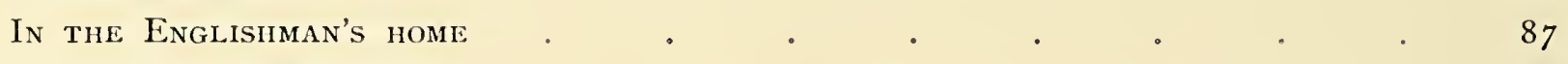

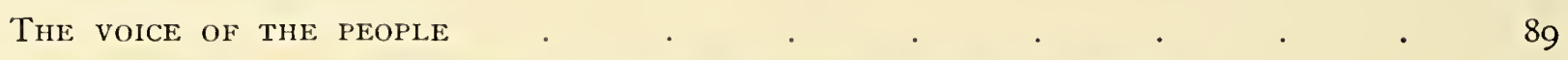

"The glory that was Greece, and the grandeur that was Rome" . . 9I

"Inasmuch as ye have done it unto one of the least of these, ye have DONE IT UNTO ME"

“Et TU, Brute?”

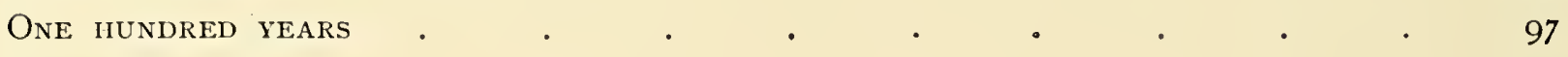

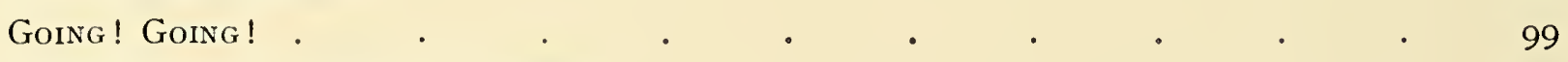

Dividends ON "A SCRAP OF PAPER" .

BelgiUm RESTORED

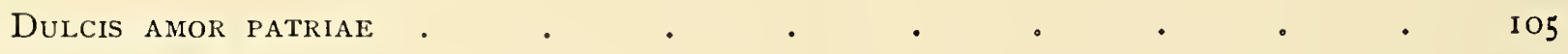

HONEY

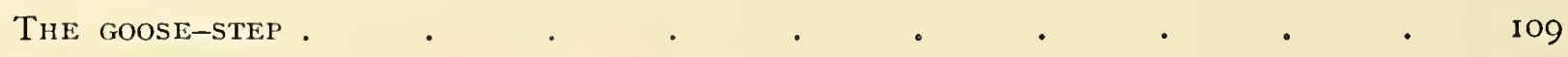

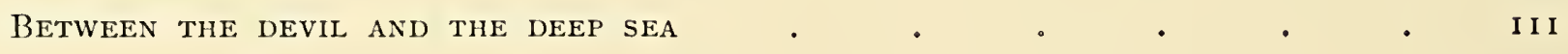

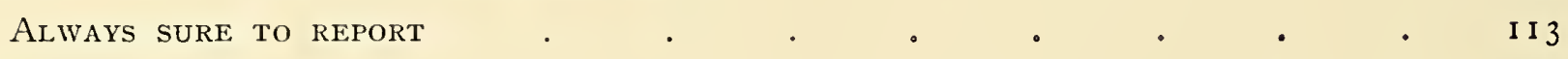

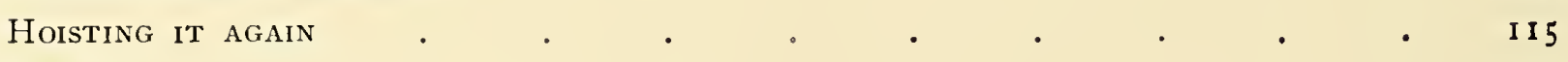

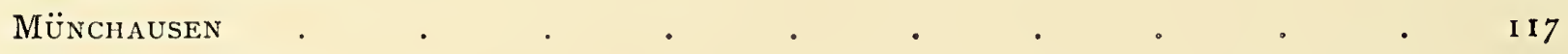

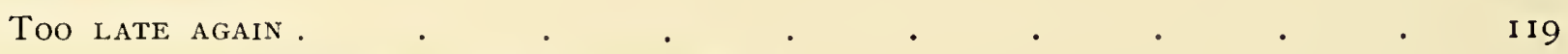

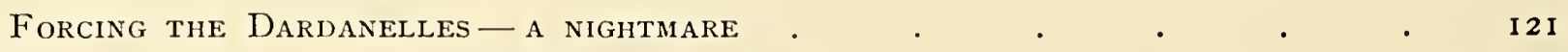

"Close up these factories! Sherman was right. Be neutral!" • • I 23

They agree on ONe Thing: "Guilty!" . . . . . . . . . . . . . 125

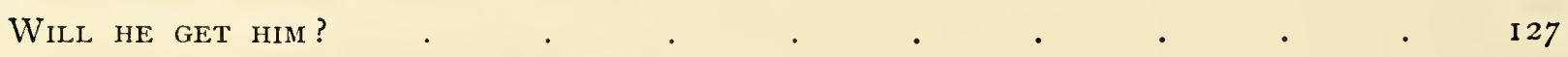

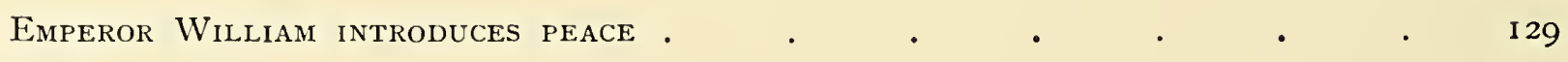

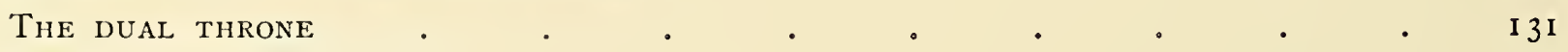

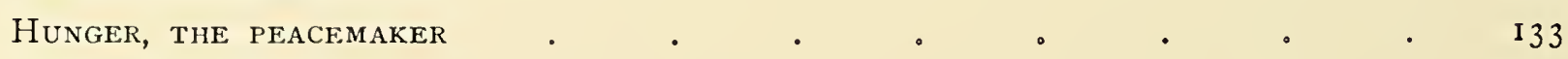

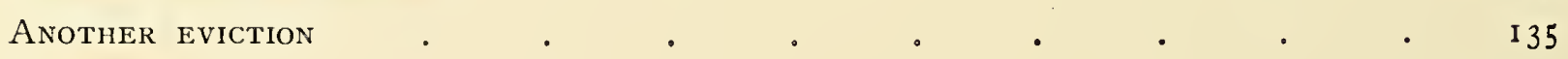

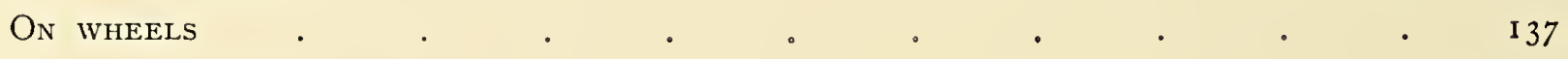

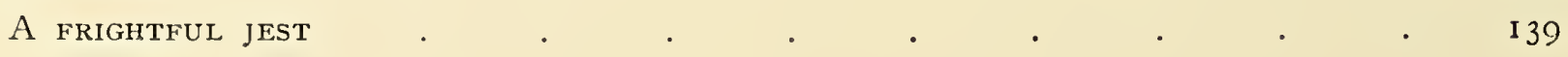




\section{LIST OF ILLUSTRATIONS - Continued}

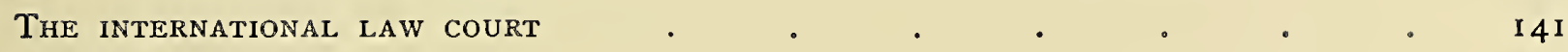

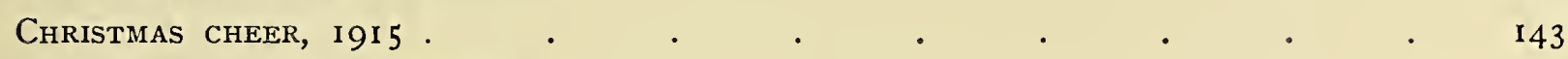

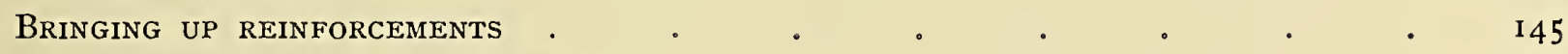

EсCE номо!

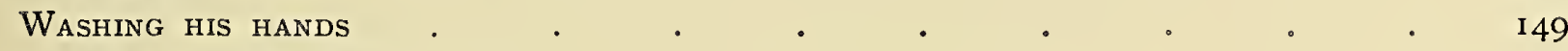

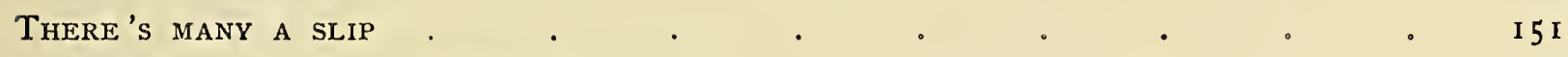

These died that THESE might live (?) . . . . . . . . . 153

The Phantom CONVOY

The MAN WITH THE SWORD . . . . . . . . . . . 157

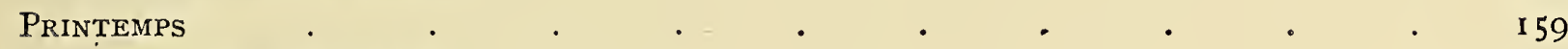

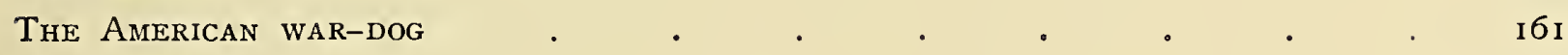

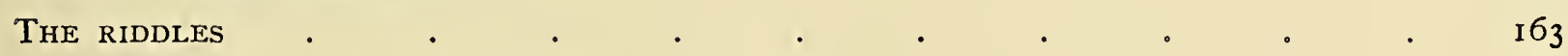

“LE JOUR DE GLOIRE EST ARRIVE" . . . . . . . . . . . . . . . 165

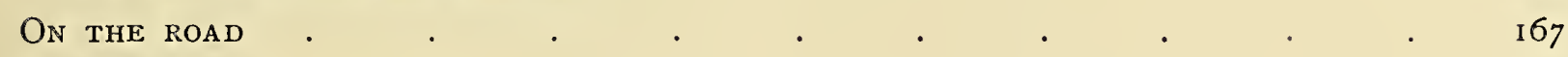

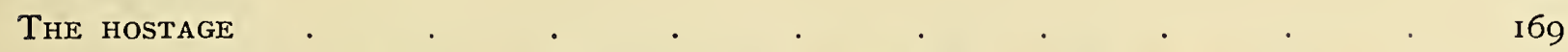

“Why continue the struggle? Can't you See we've won on sea and land?" i7 I

"Now Remember what I told you" . . . . . . . . . . . . . I73

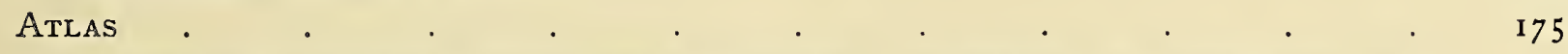

The German submarine commander's accurate conception of the boat he BLEW UP .

"I CAN Not tell a lie: he did it with his little submarine" . . . I79

AWAITING ORDERS - WHICH FLAG ? . . . . . . . . . . . . . . I8I

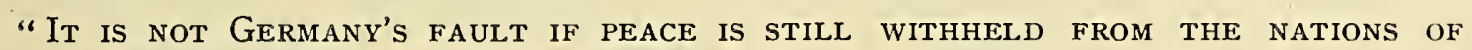
EUROPE" . $\quad . \quad$.

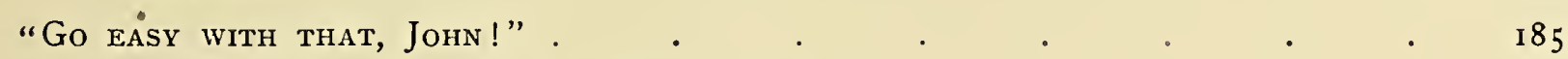

"Unceasing was the Play of Wretched hand" . . . . . . . . I 187

Thirsty

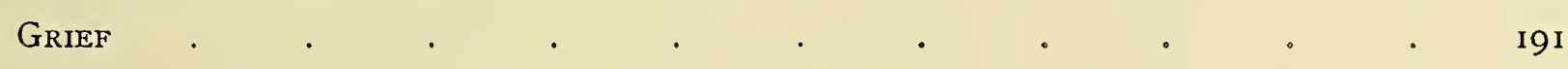

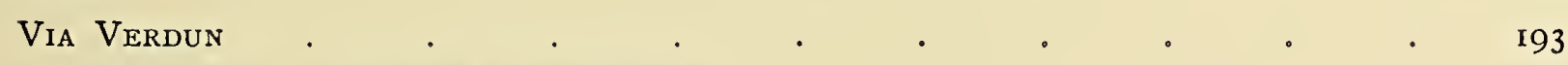

"The Situation CONTINUES SATisfactory" . . . . . . . . . . . . 195

MAY THE SPARKS NeVer REACH IT . . . . . . . . . . . . . . . . 197

“Let The Bugles SOUnd the TRUCE of God to THE whole world Forever!" 199 



\section{ONE HUNDRED}

CARTOONS BY CESARE 


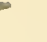




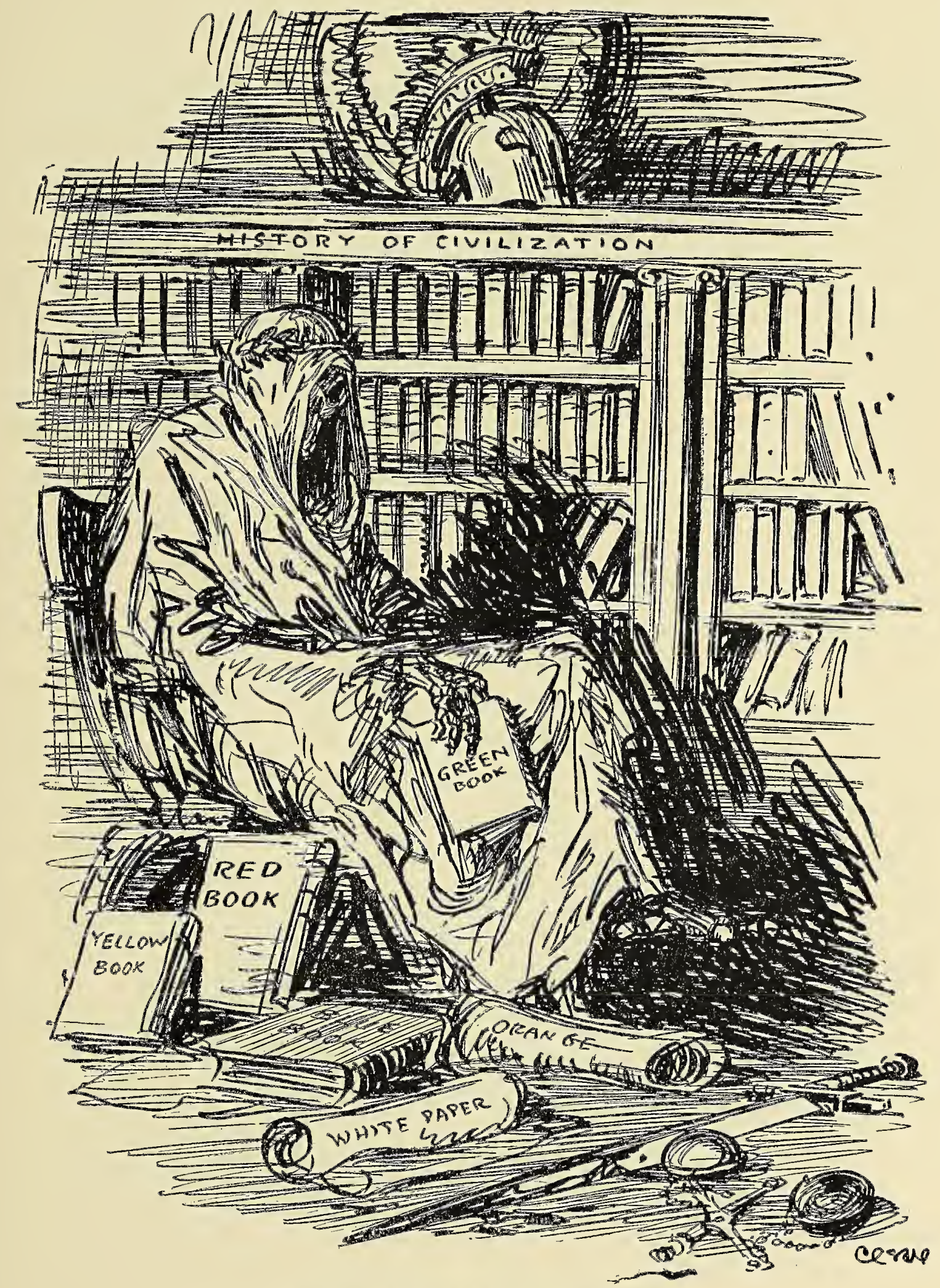

THEY ARE ALL RED TO HIM 



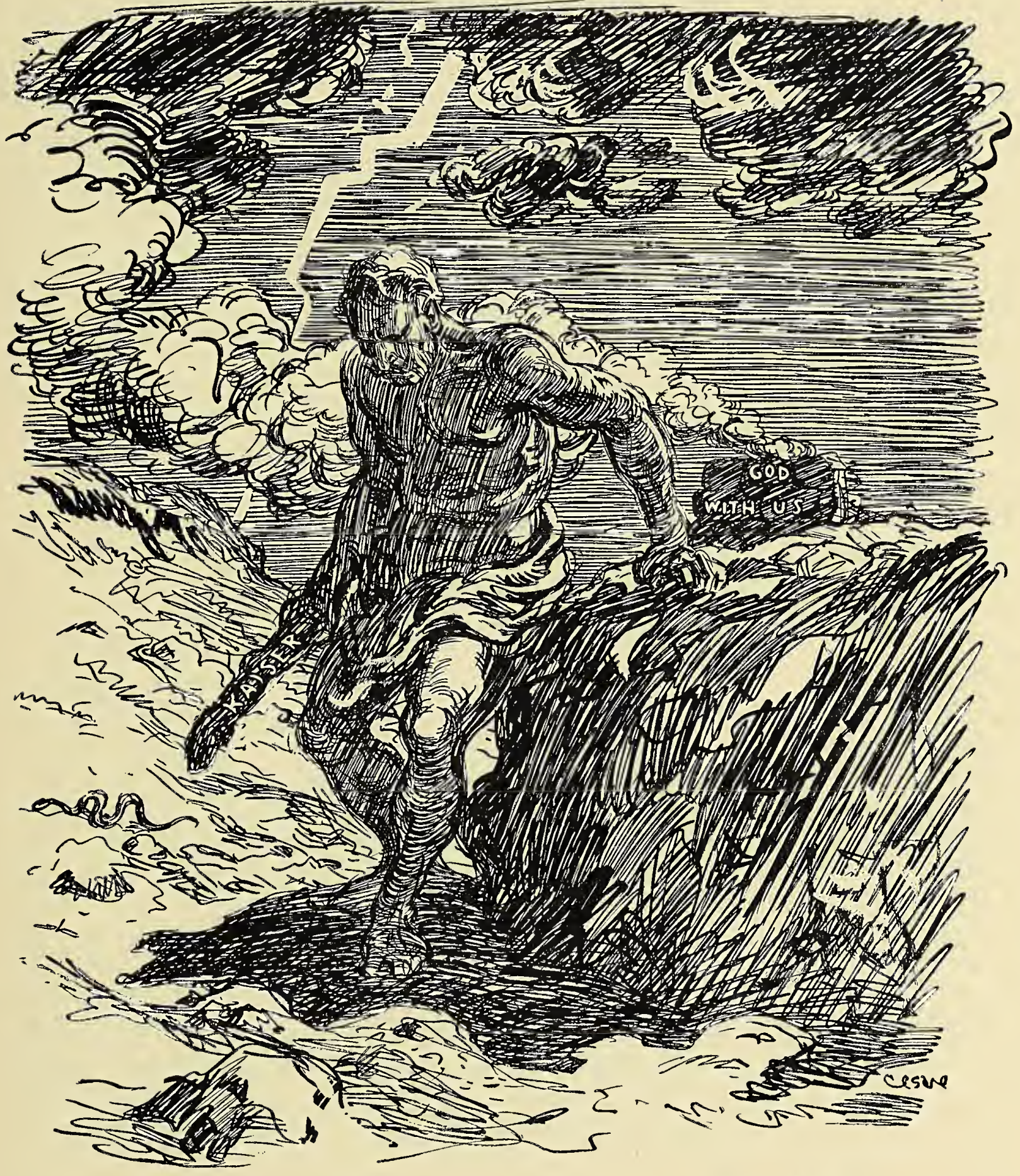

Suggested by Dorè's picture

"WHAT HAVE YOU DONE WITH YOUR BROTHER ABEL?" 



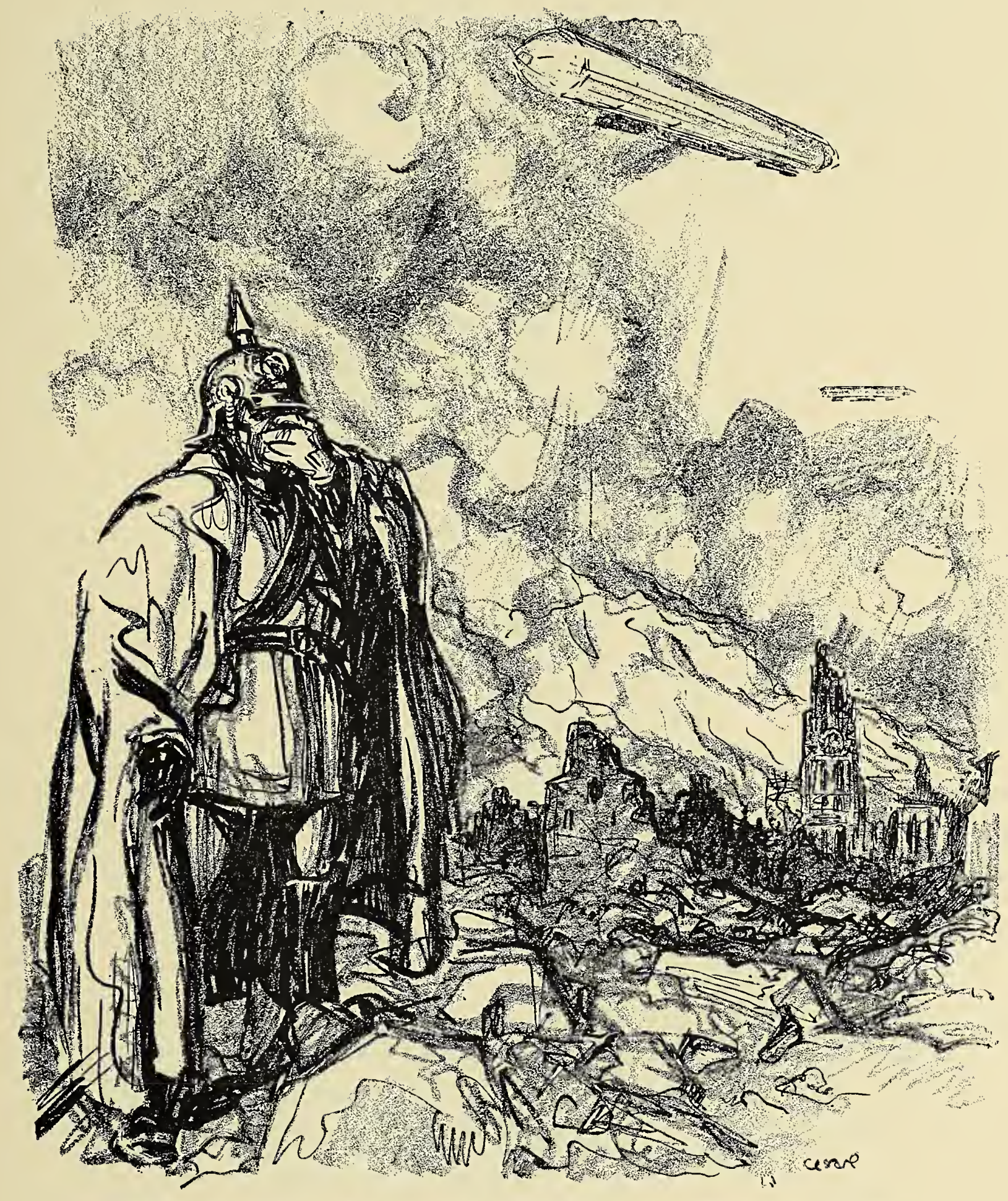

THE KAISER : "MY HEART BLEEDS FOR ANTWERP, TOO" 



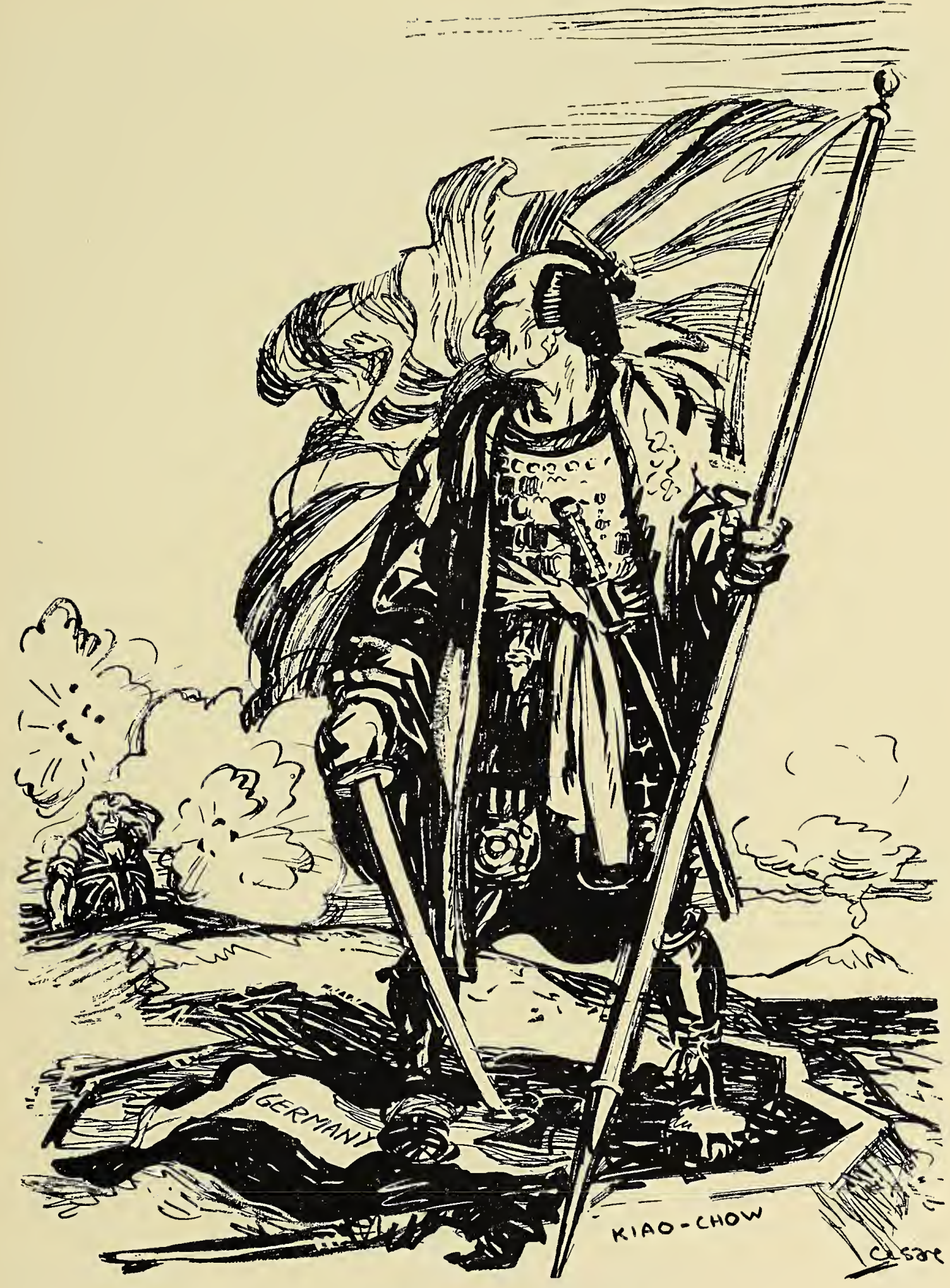

THE HONORABLE ALLY 



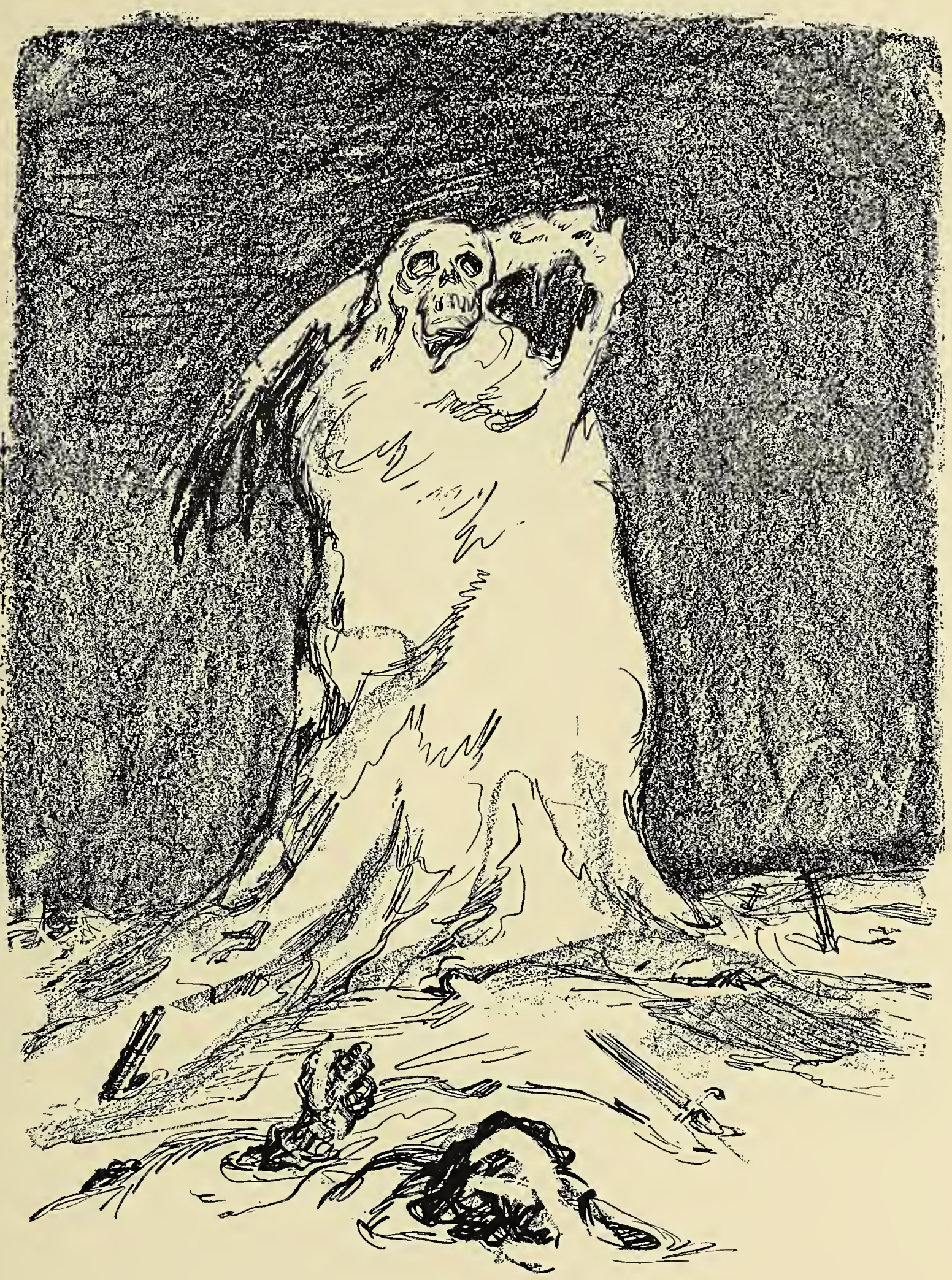

THE SNOWMAN 



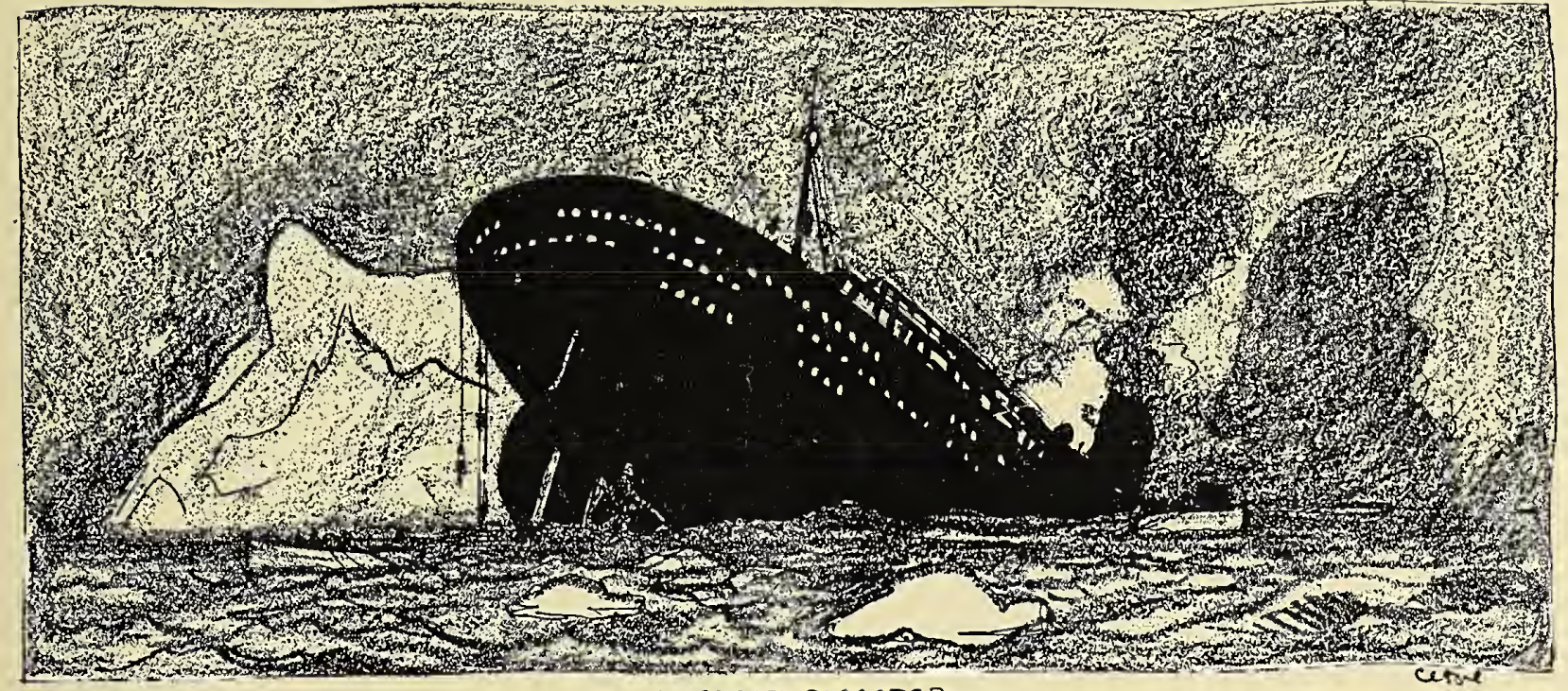

A GREAT DISASTER

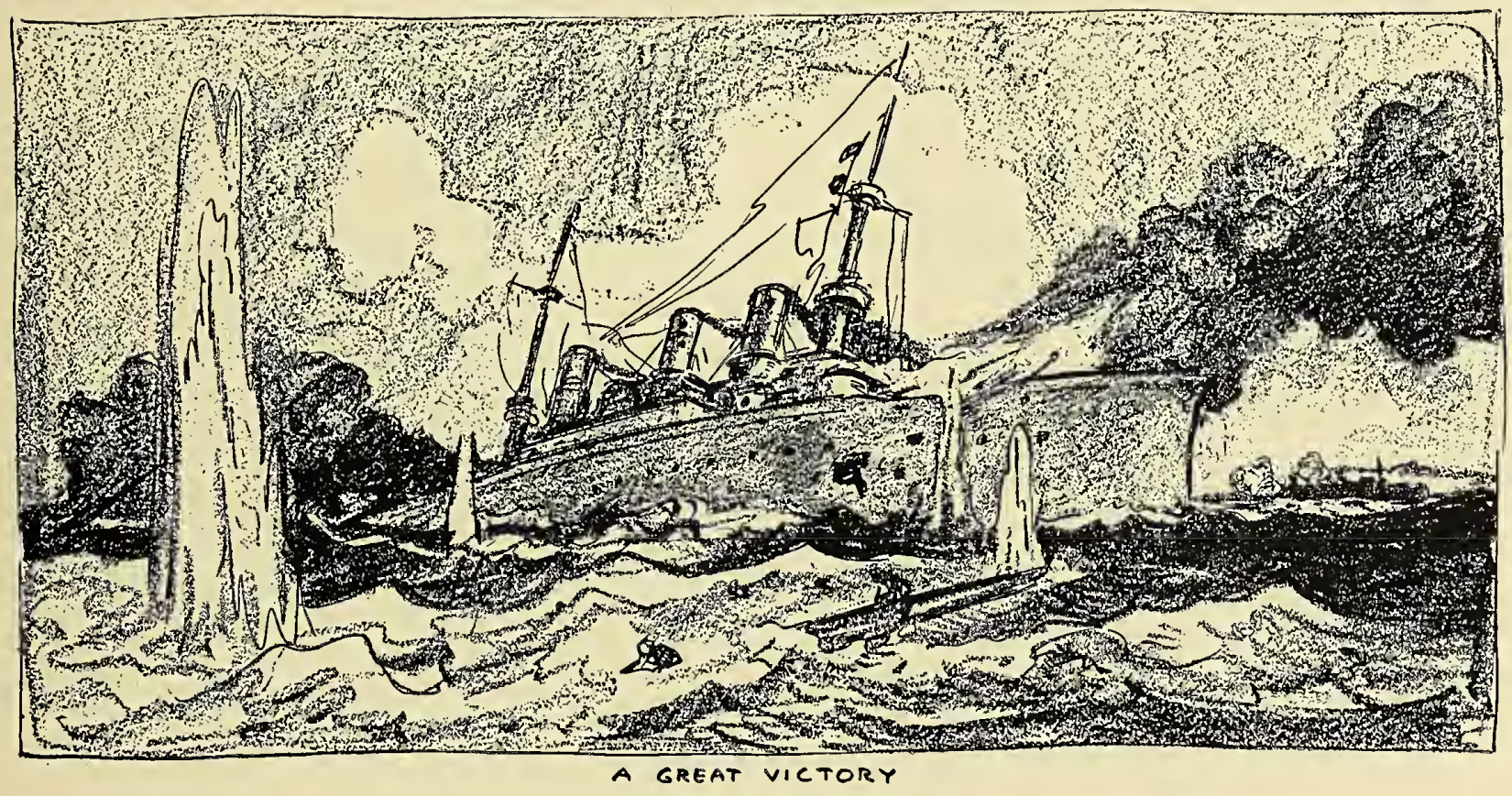

[1 11$]$ 



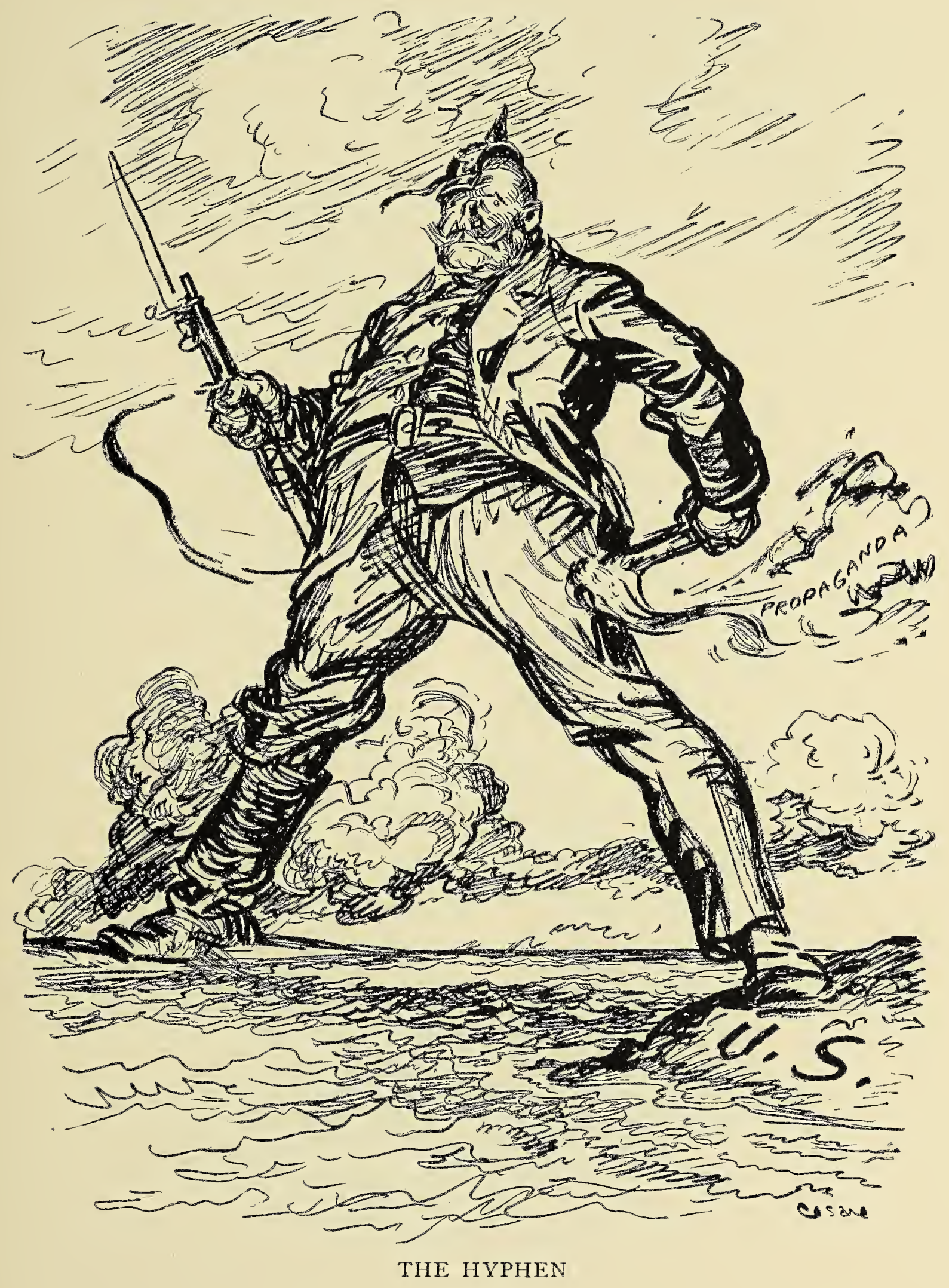





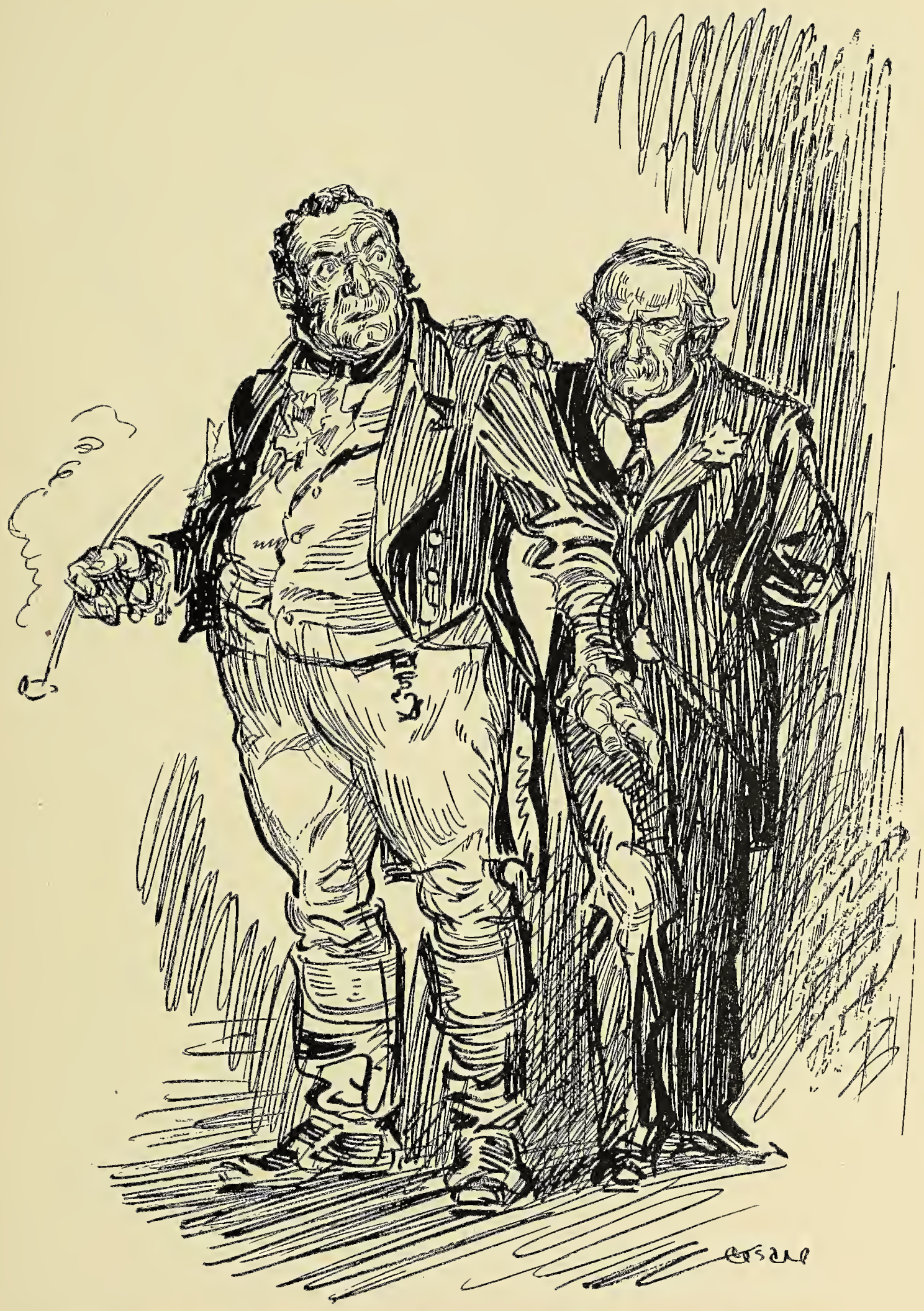

LLOYD GEORGE, MINISTER OF MUNITIONS : "ENGLAND EXPECTS - " 



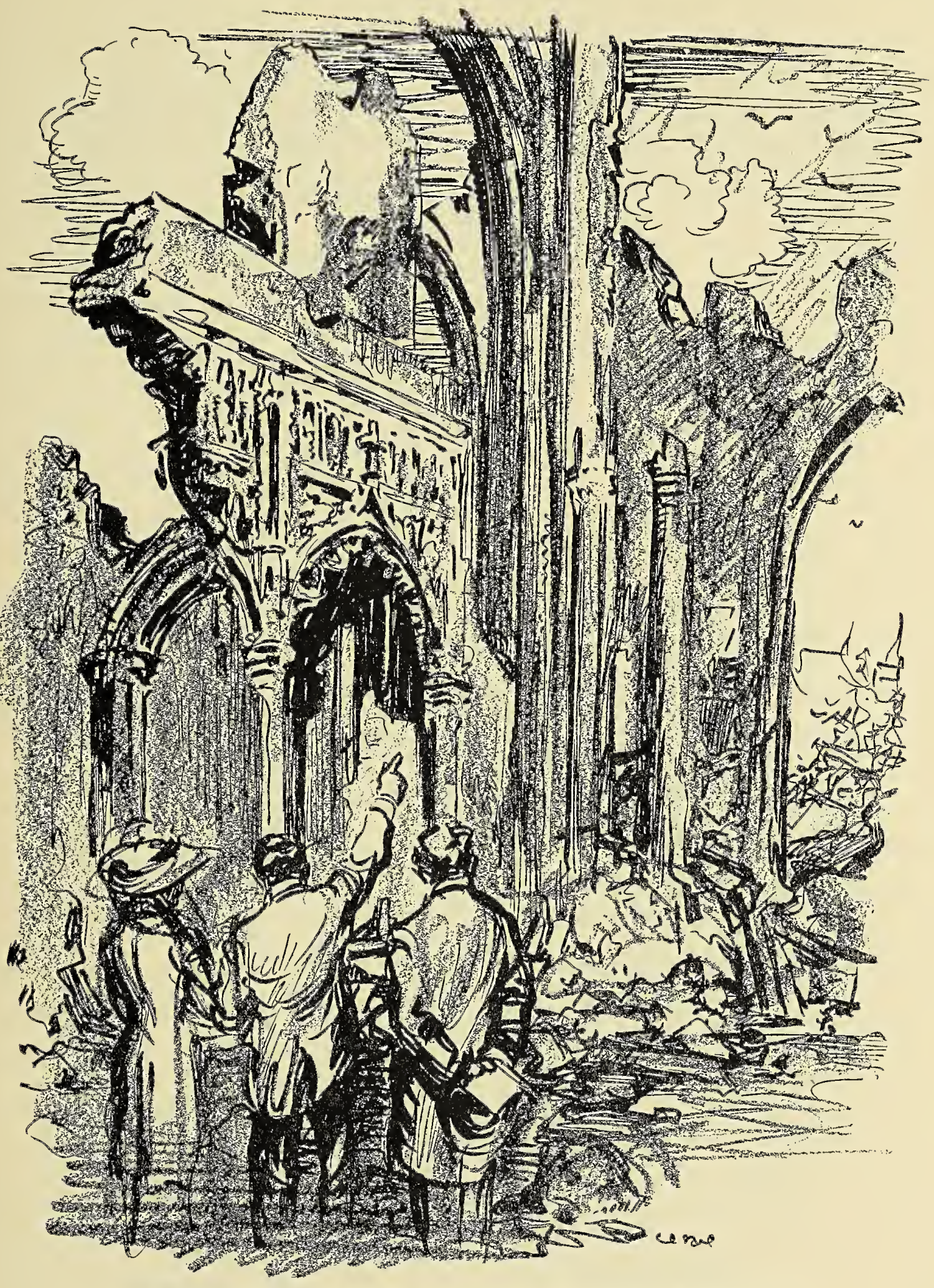

TO-MORROW'S GUIDE: “THESE ARE THE RUINS OF WILLIAM THE SECOND" 



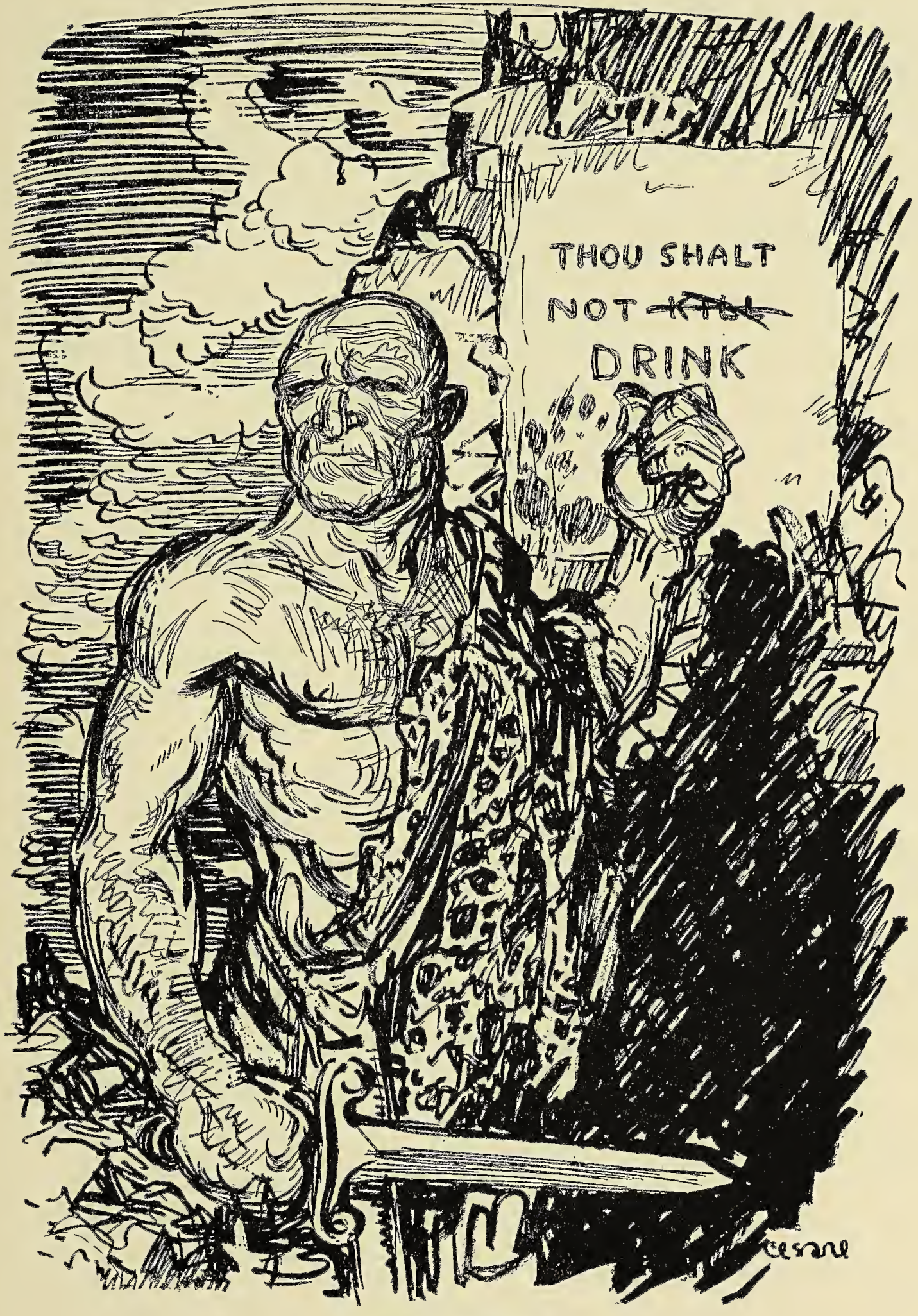

WAR'S EDICT 


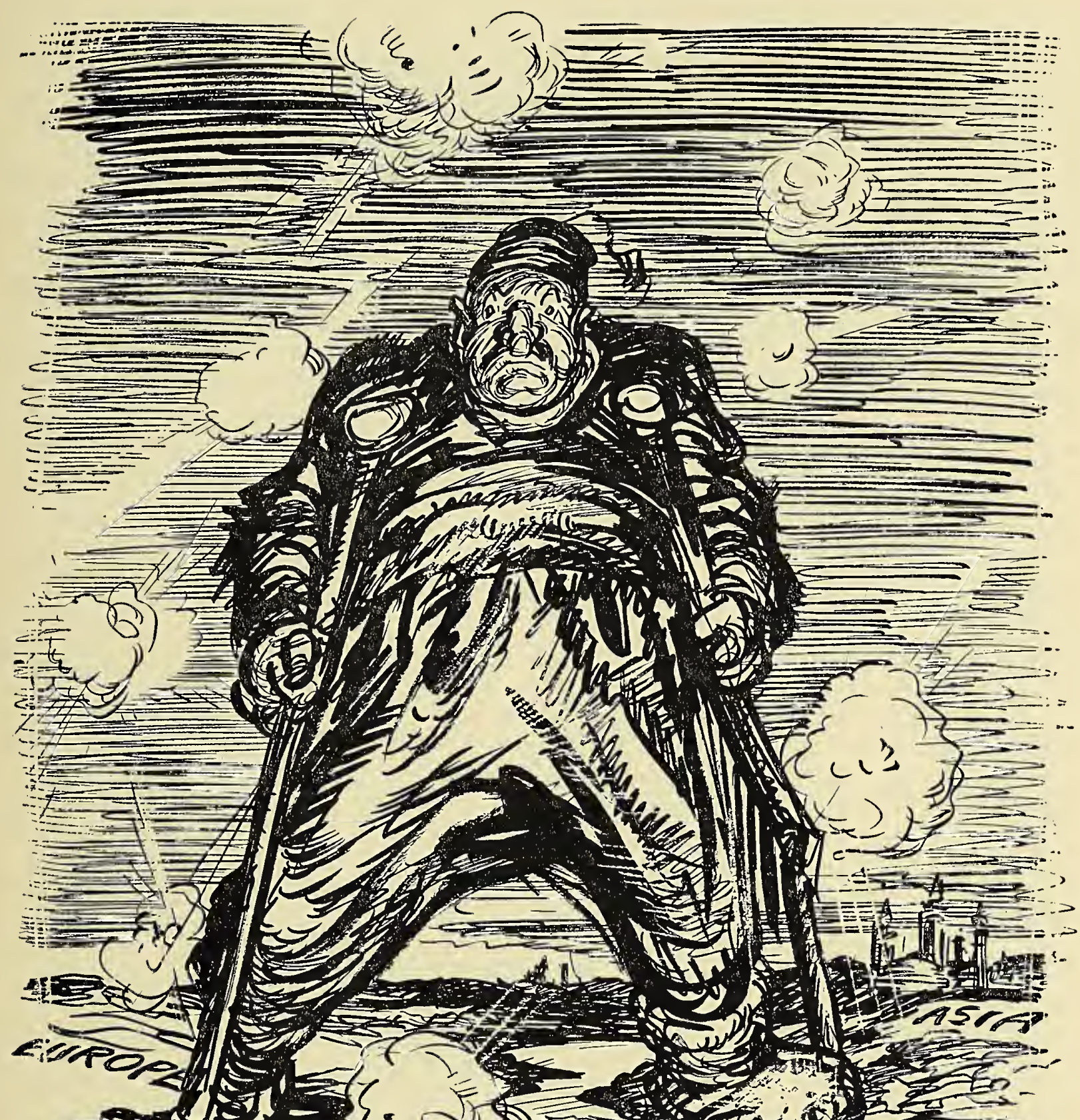

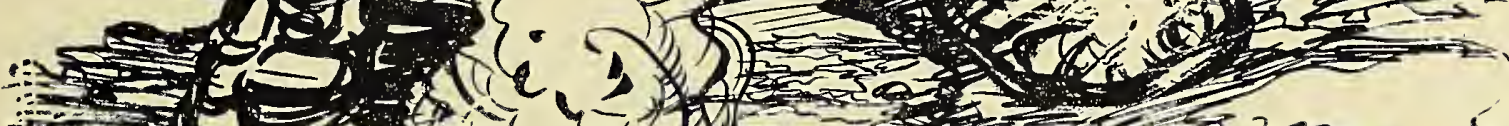

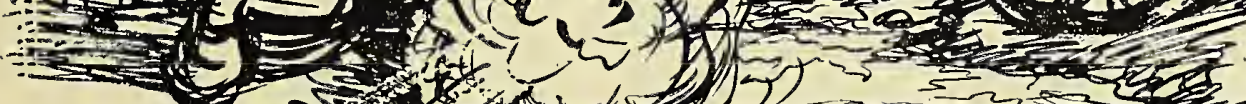

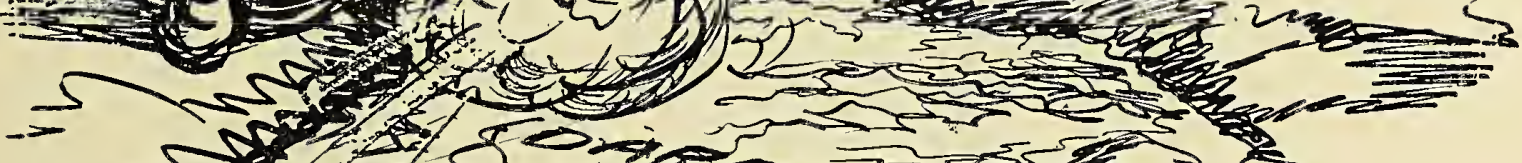

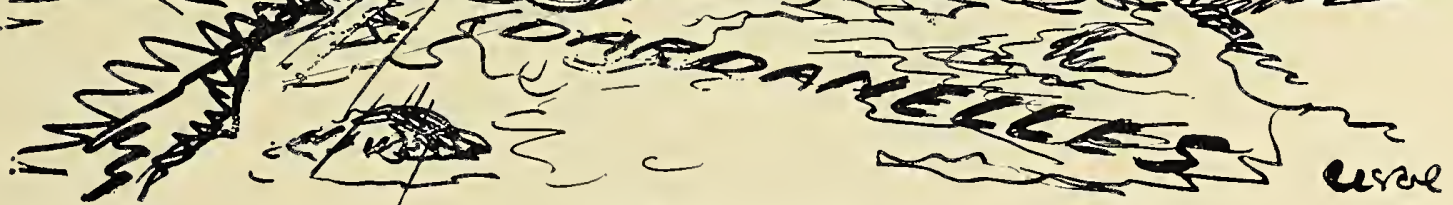

THE COLOSSUS 



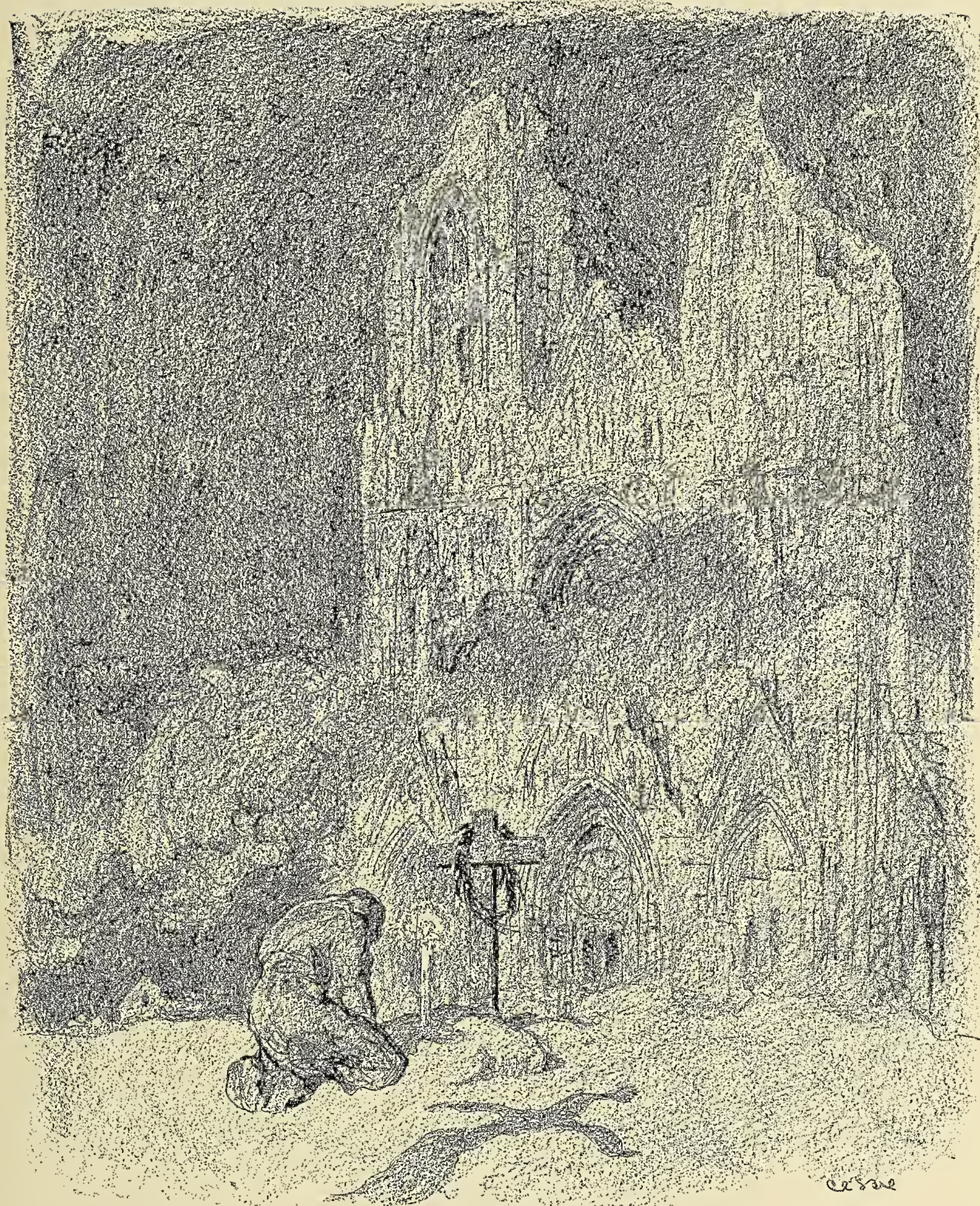

CHRISTMAS MORNING

[23] 
. 


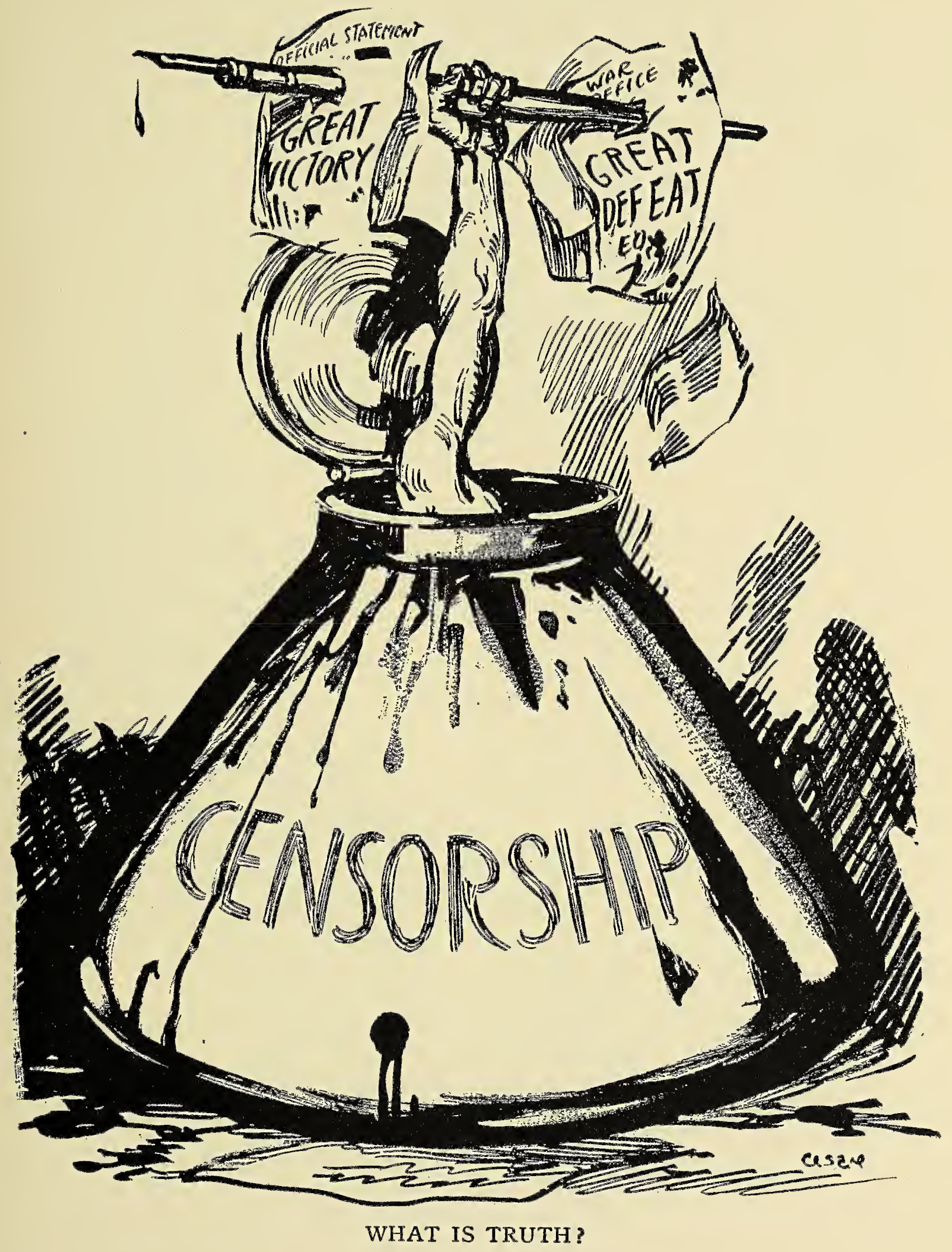





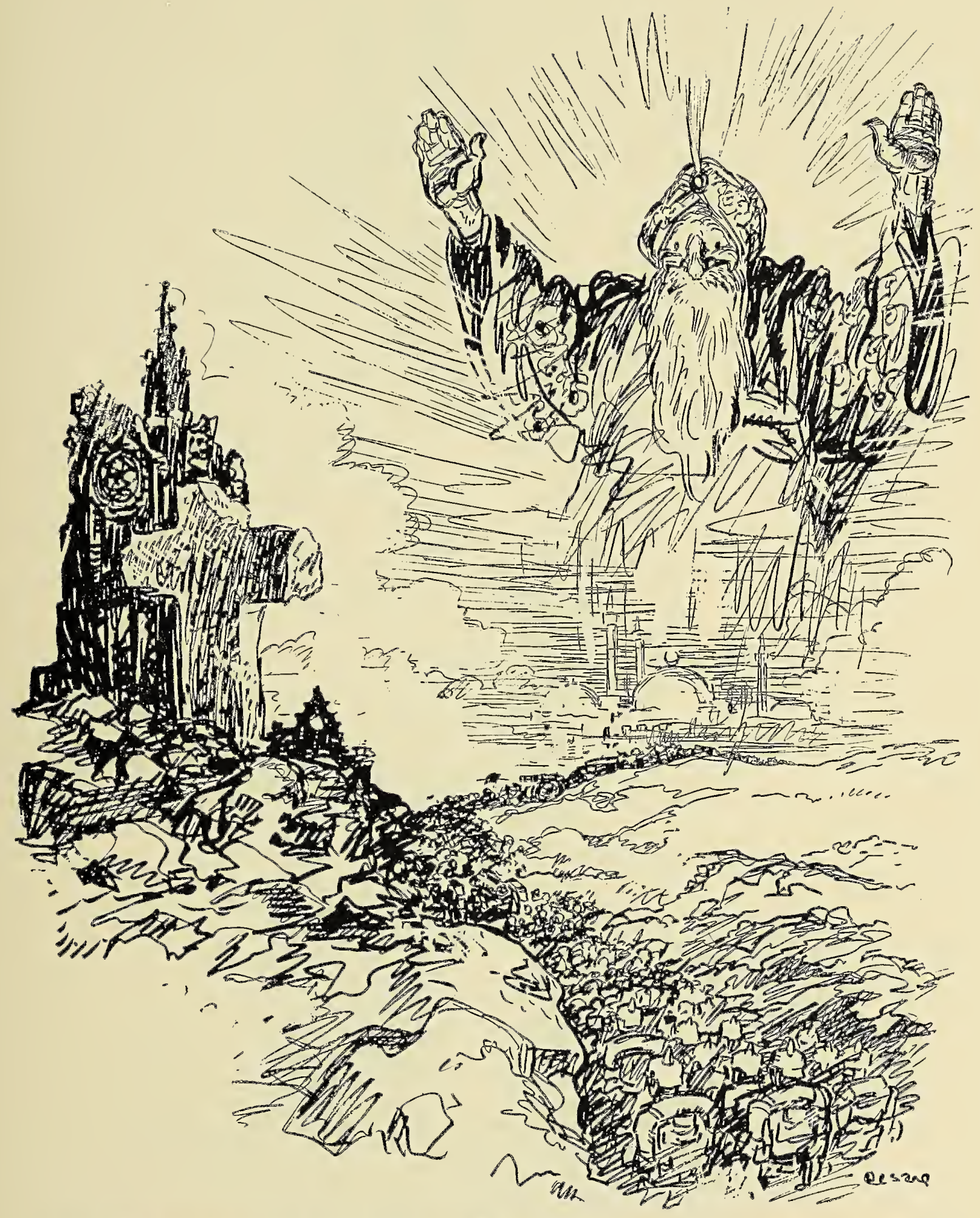

"BY THE BEARD OF THE PROPHET, OUR FUTURE LIES IN THE EAST!" 


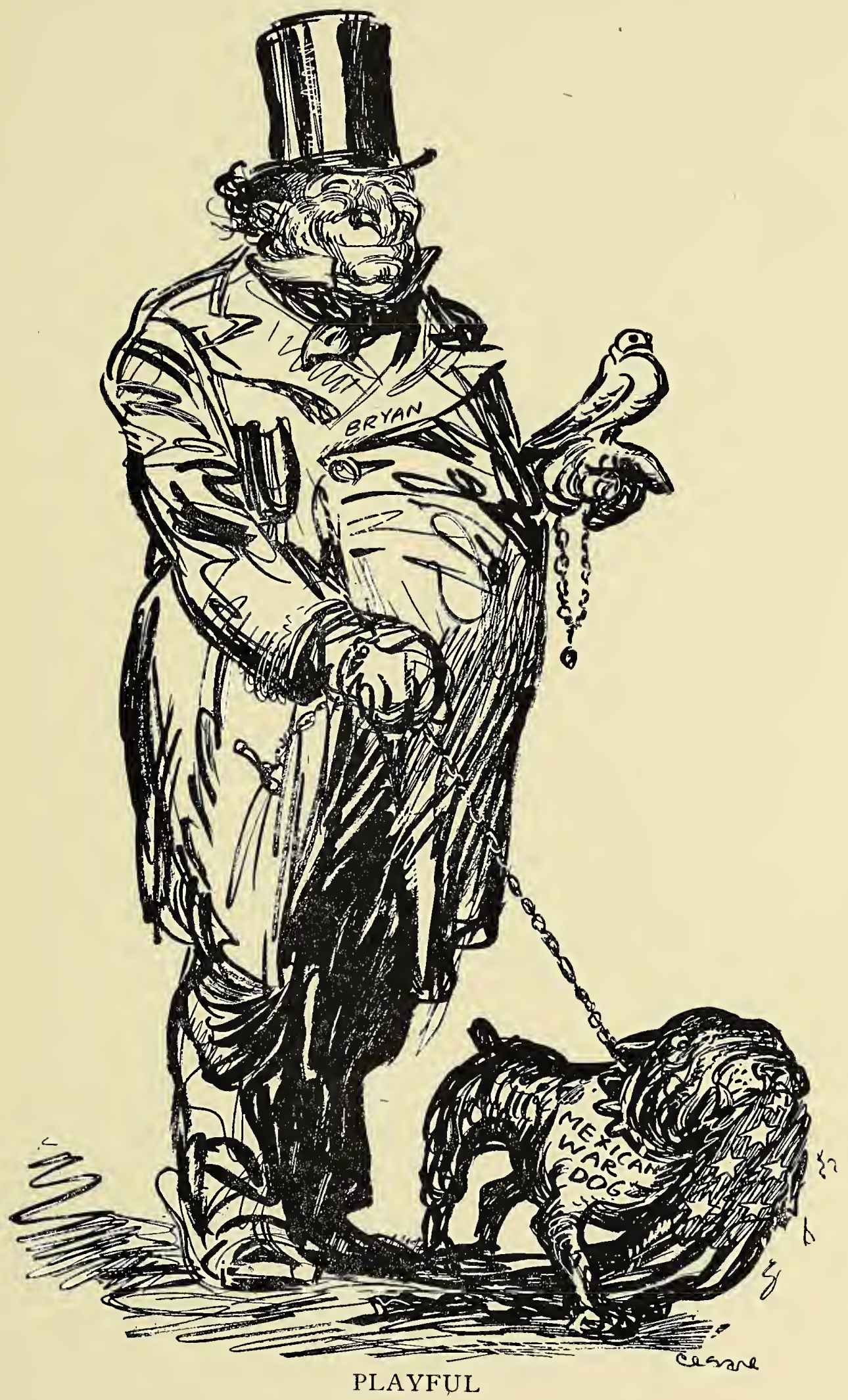

[29] 



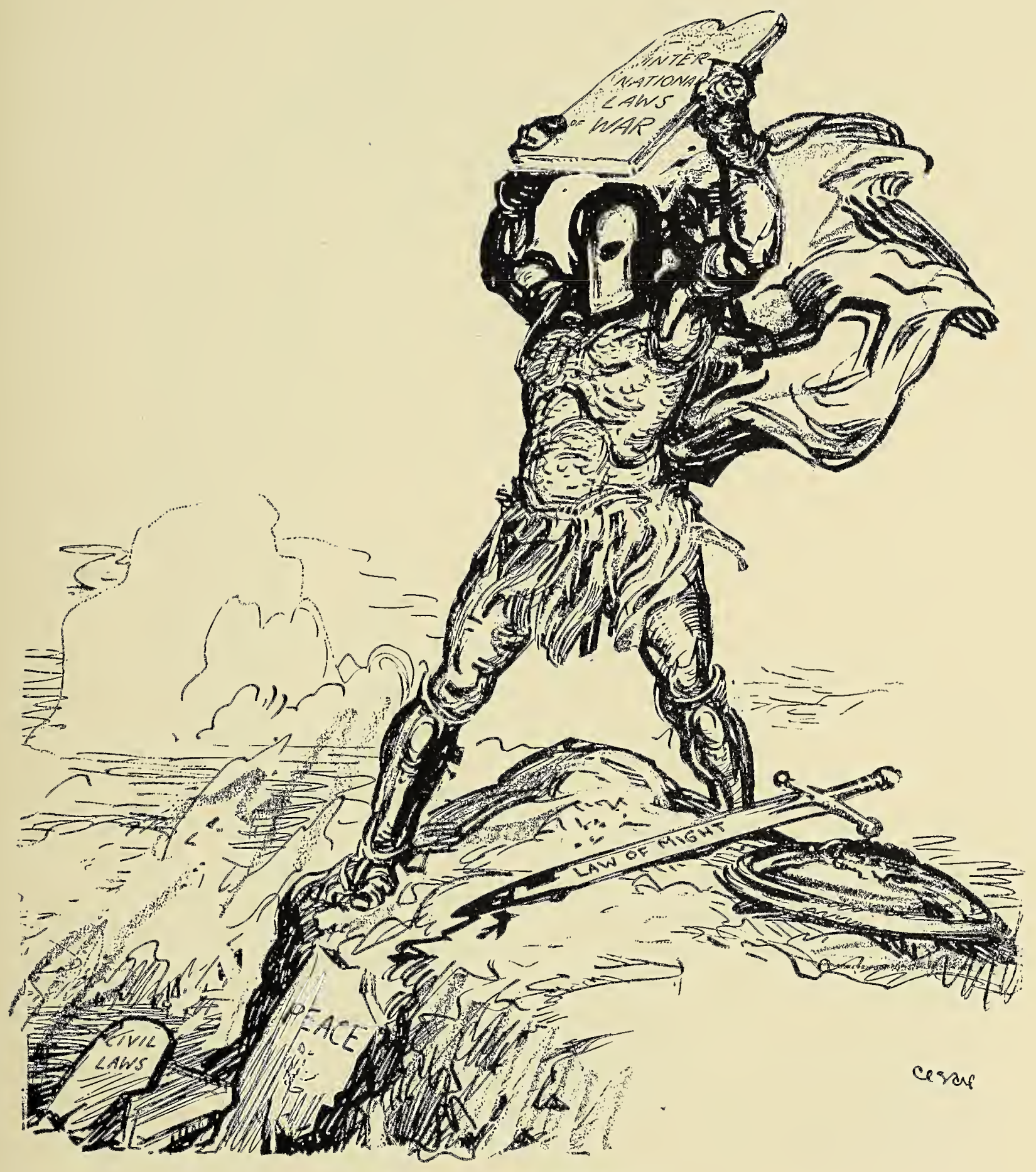

THE LAW-BREAKER 



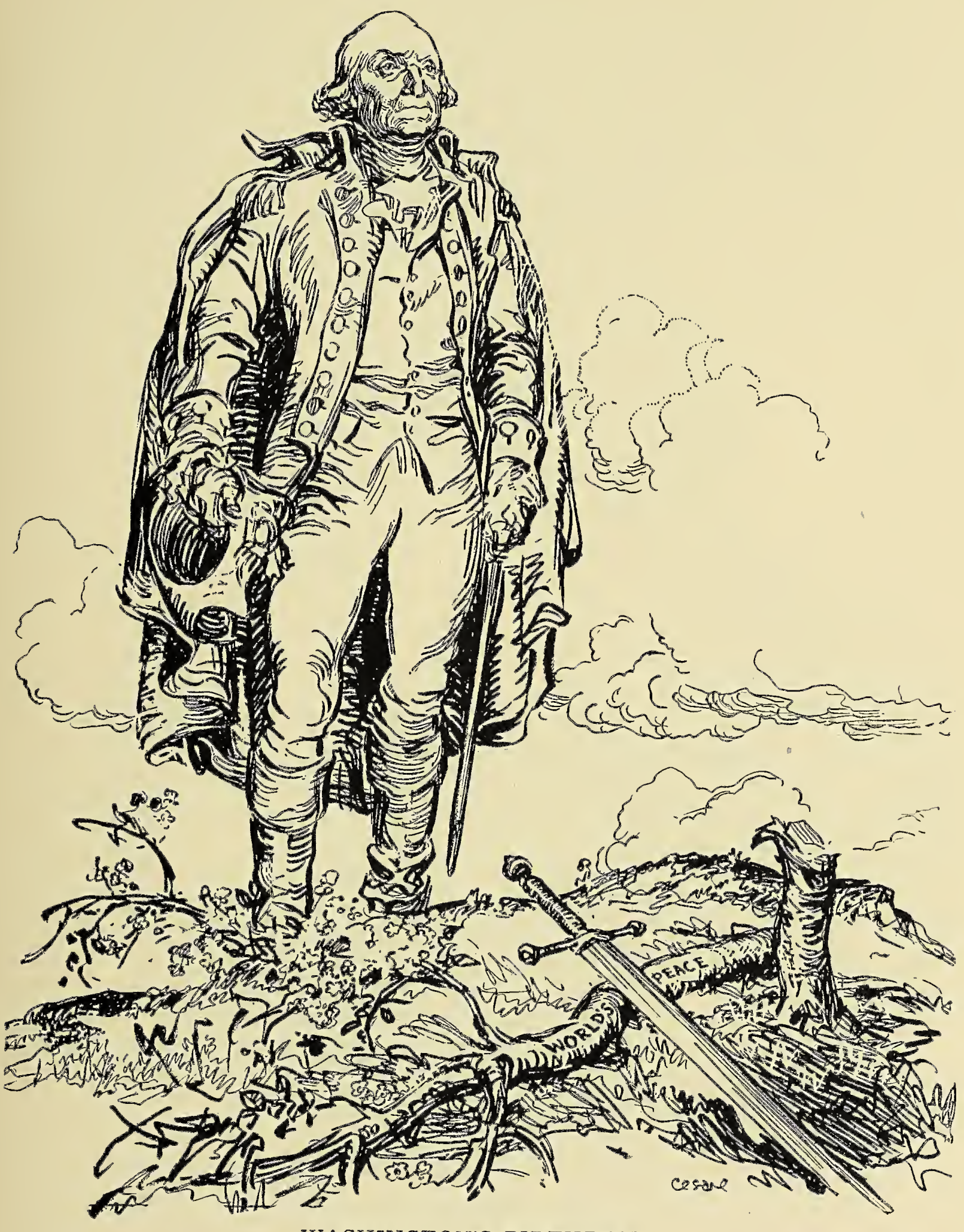

WASHINGTON'S BIRTHDAY

1732-1915 



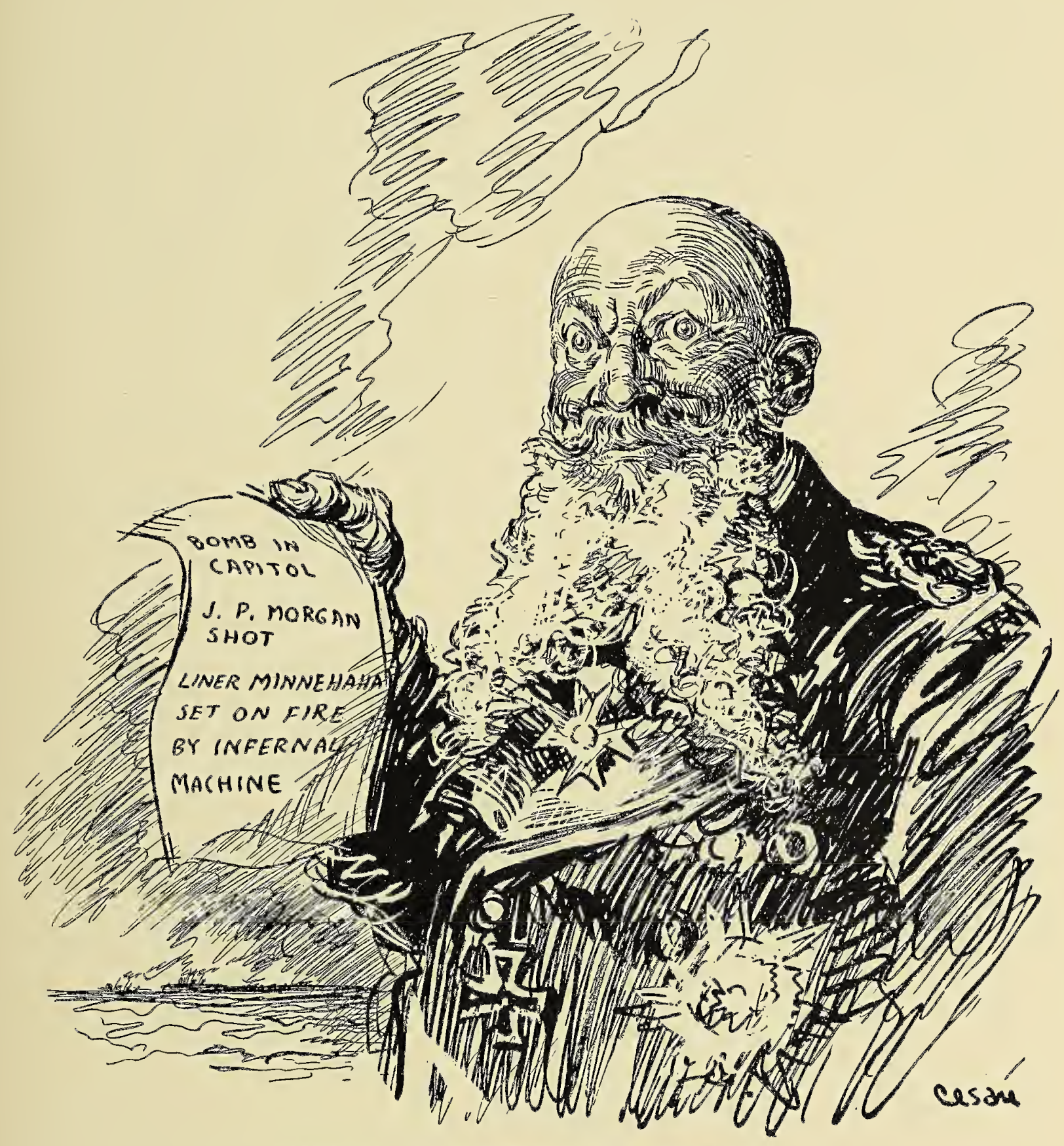

TIRPITZ: "DREADFUL! TOO BAD!" 


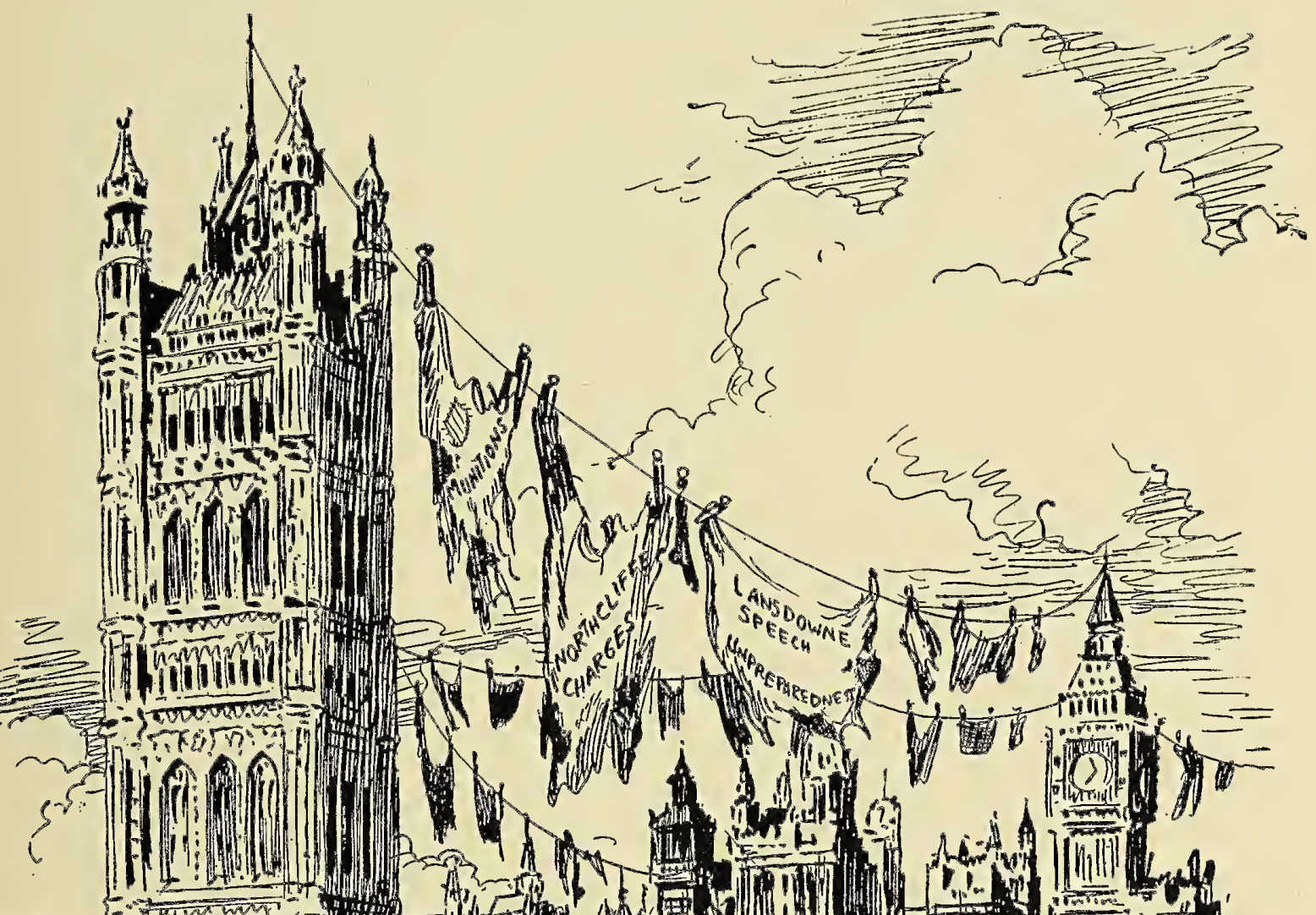

sin

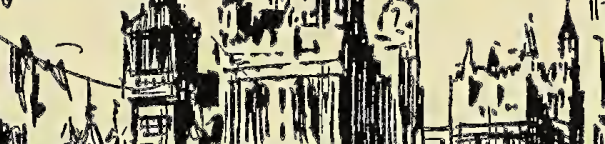

7 . (

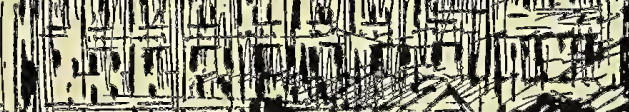

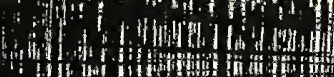

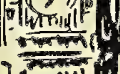





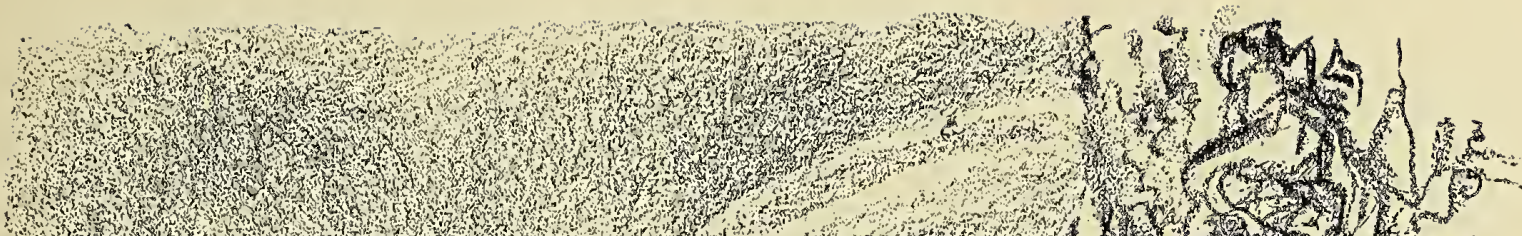
1.7.

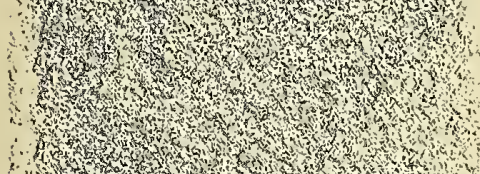

19:-2:

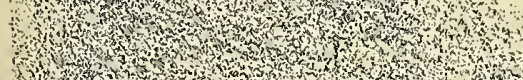

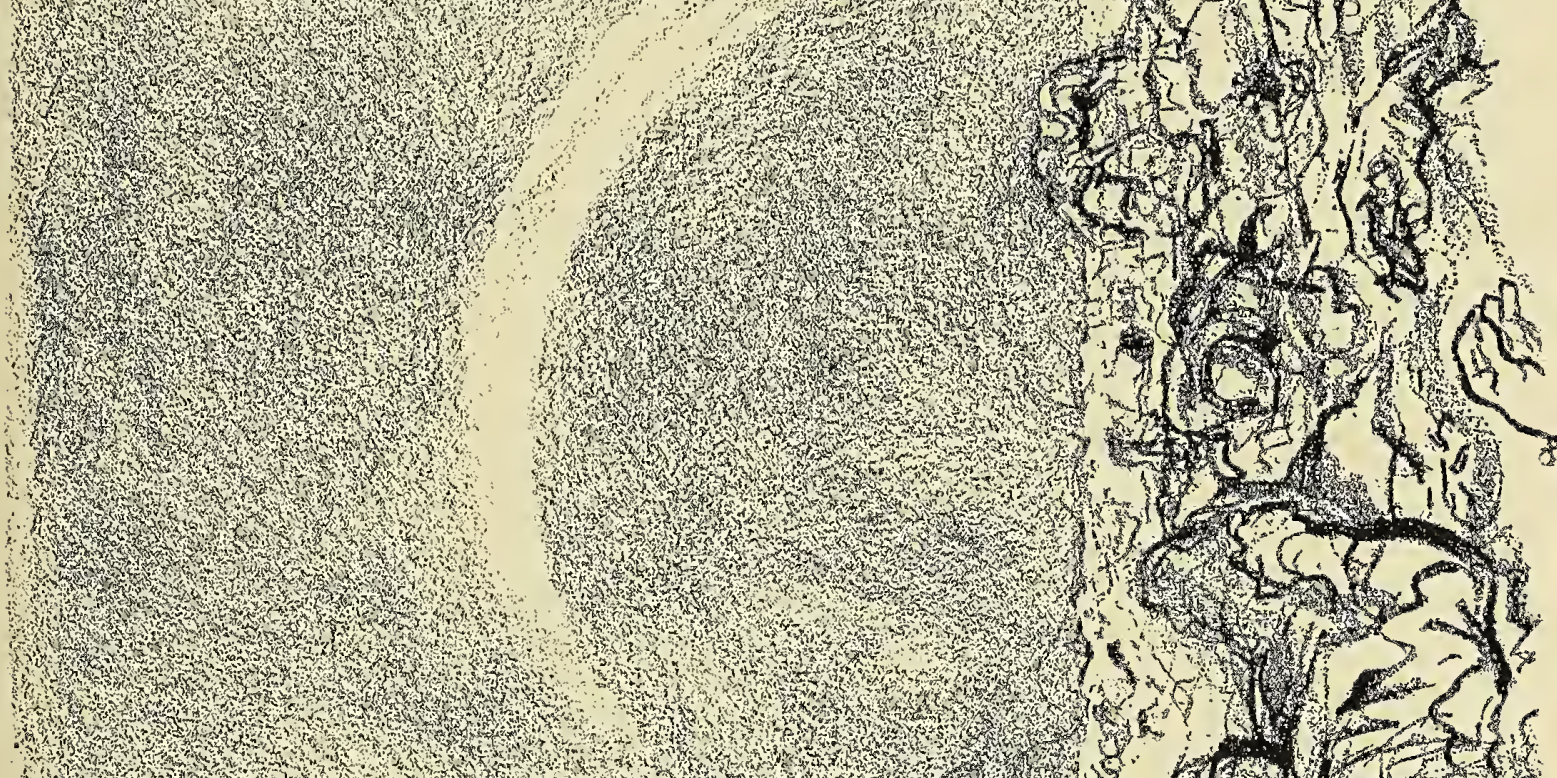

1.

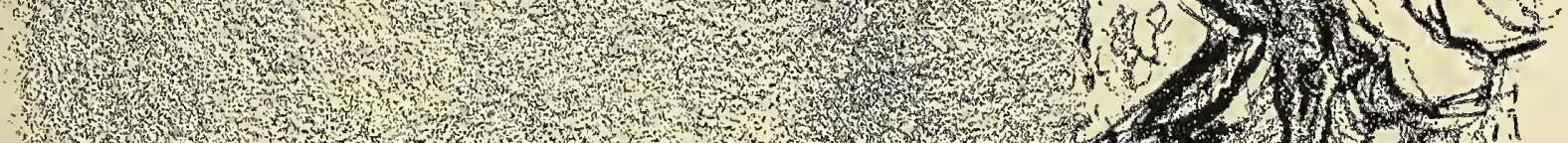

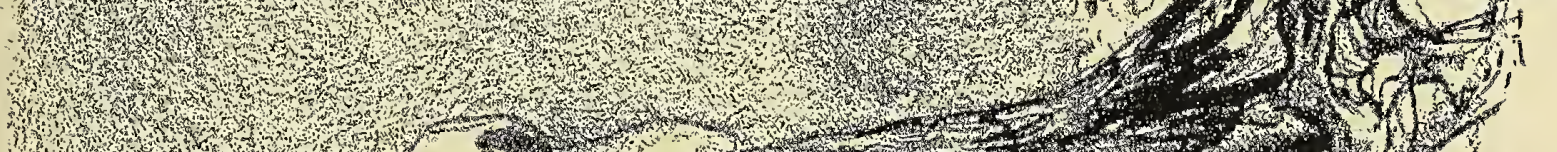

Mrot

Hoth

H.t.

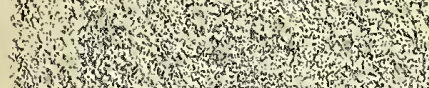

Tht

16.t.

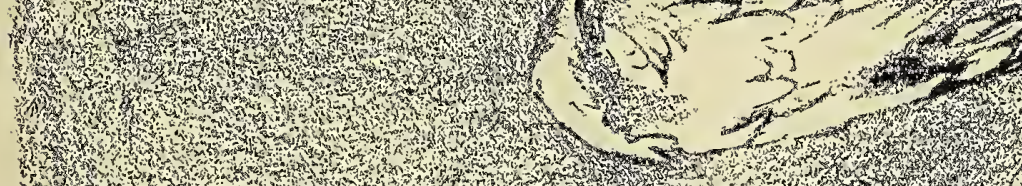

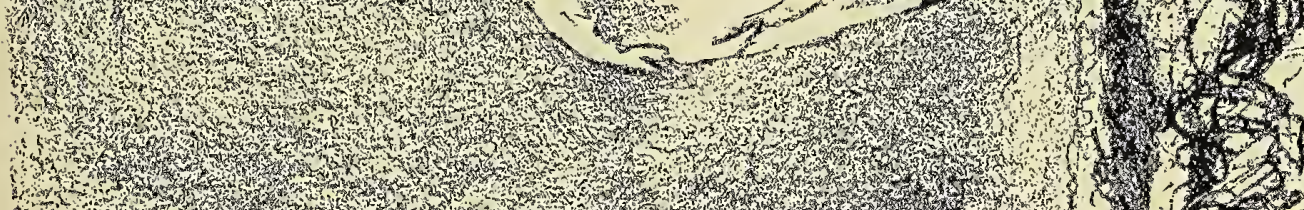

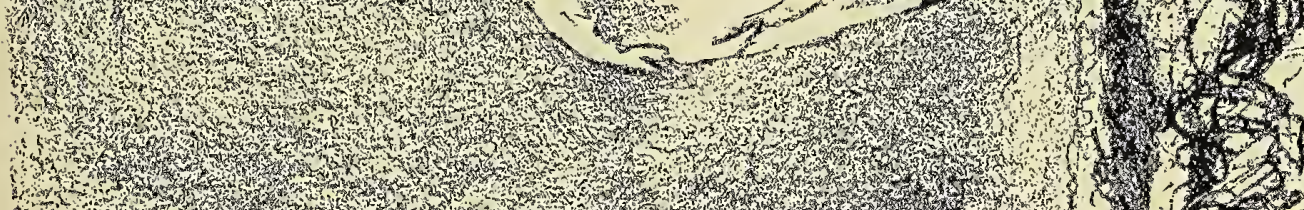

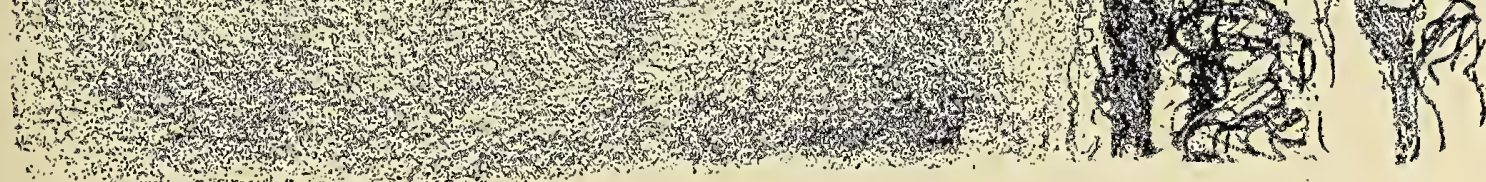





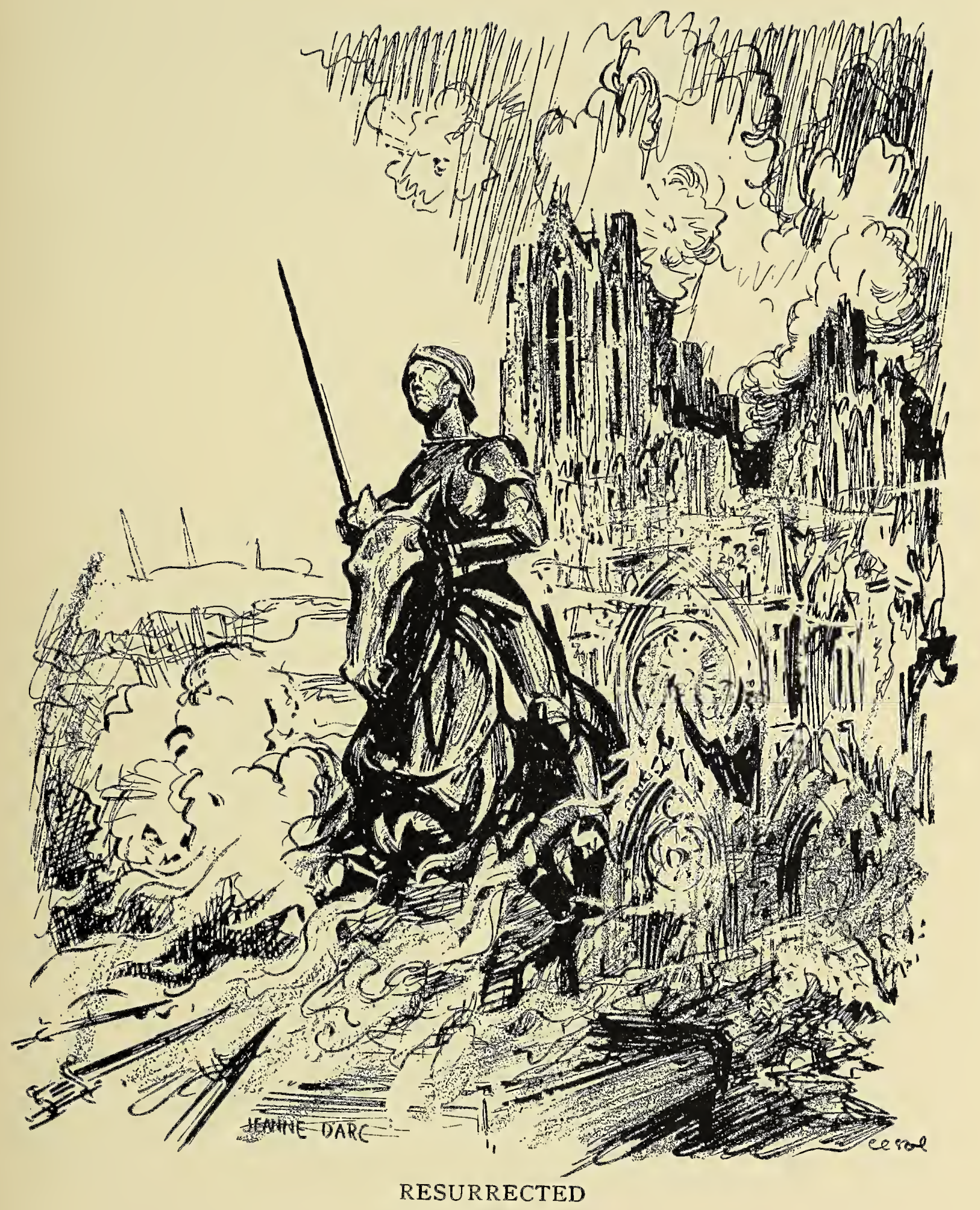





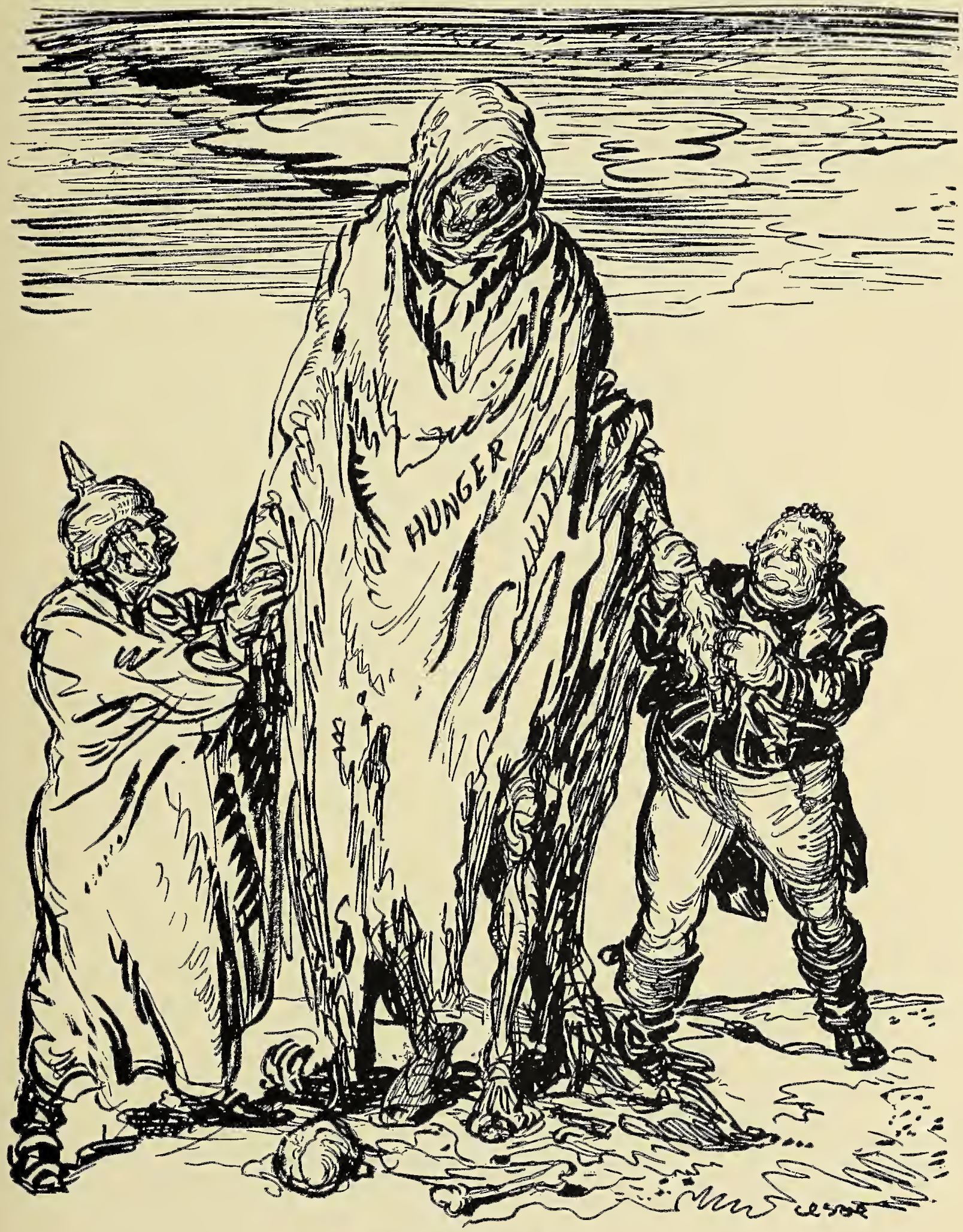

THE GREAT ALLY 


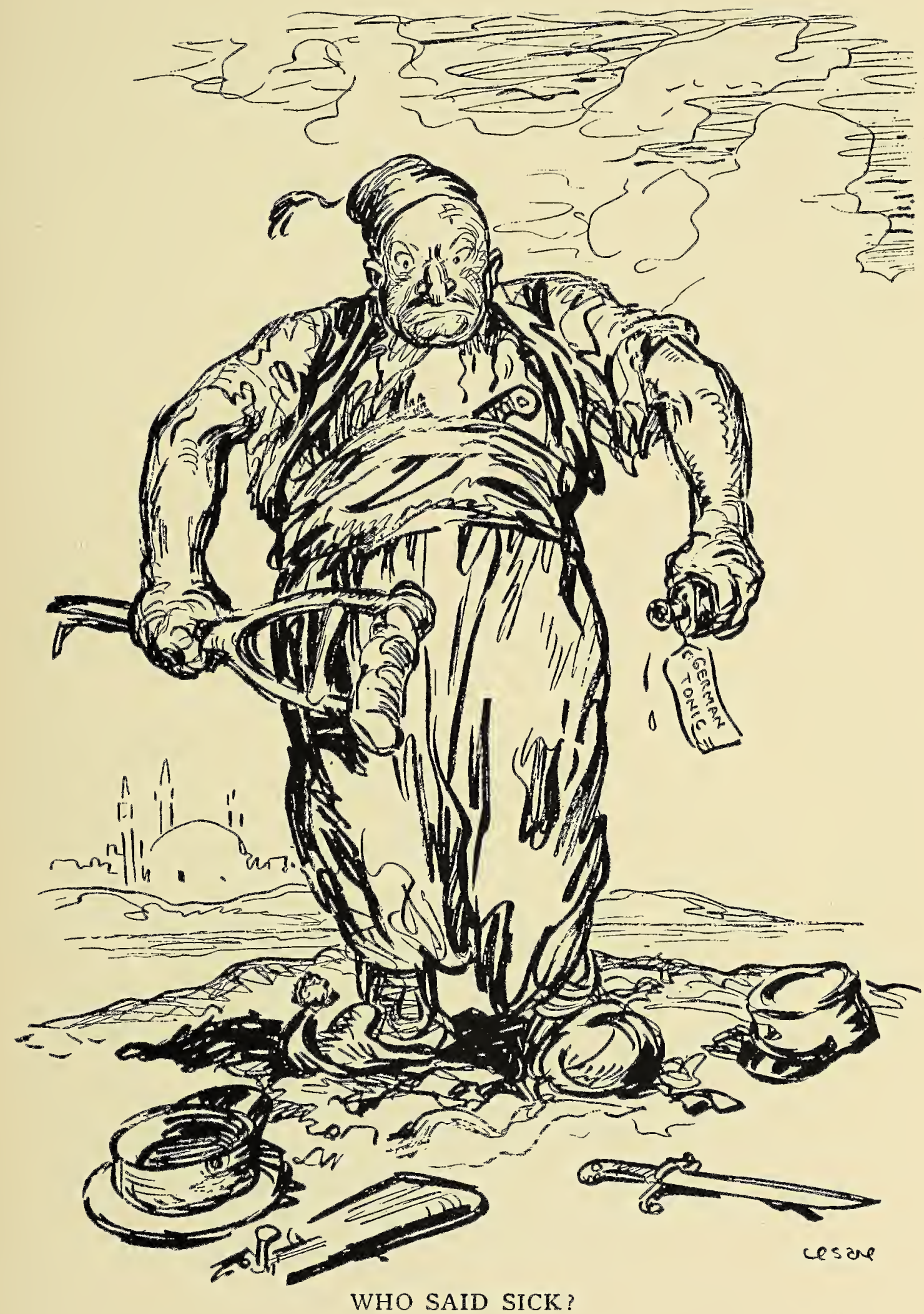





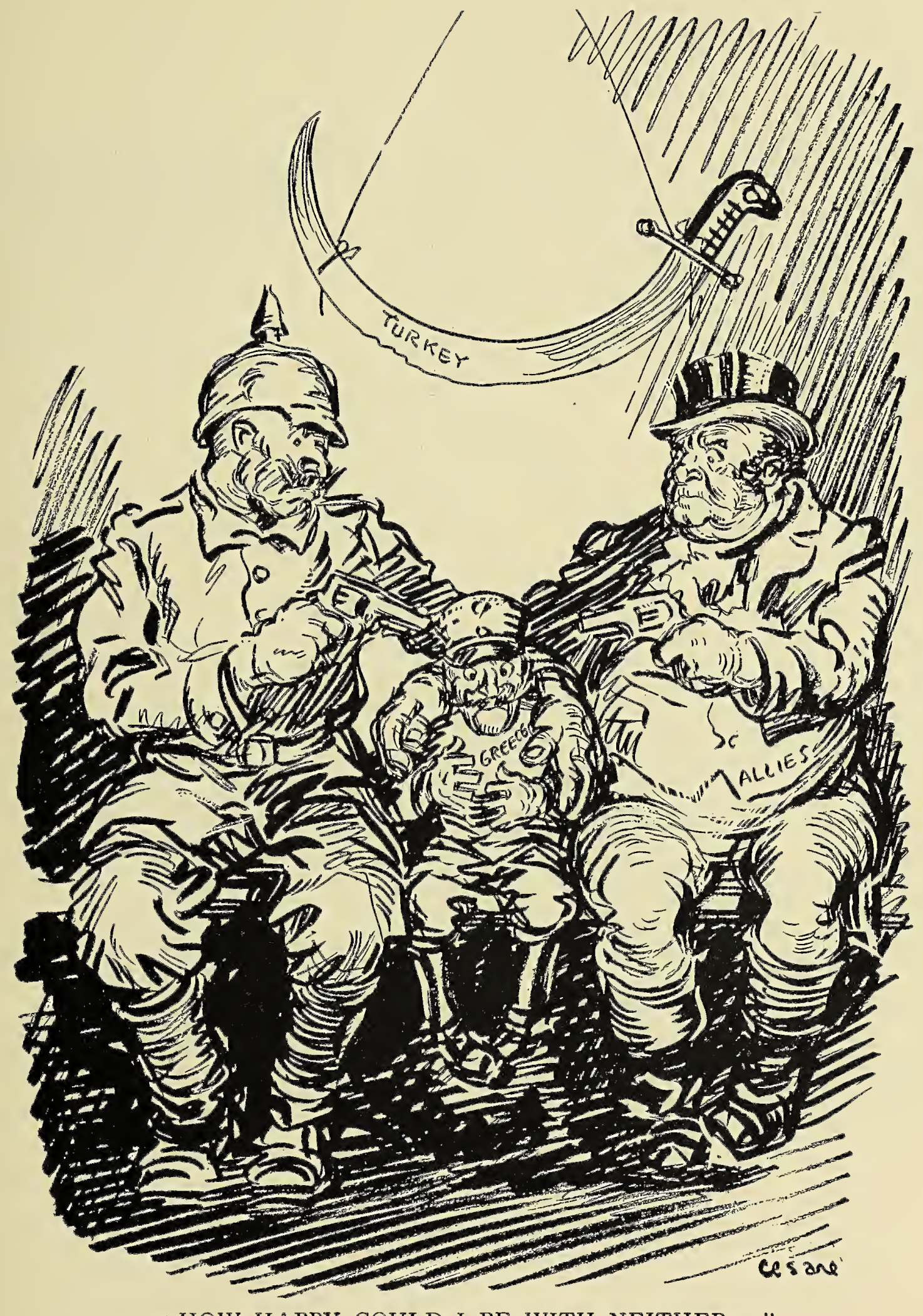

"HOW HAPPY COULD I BE WITH NEITHER - " 



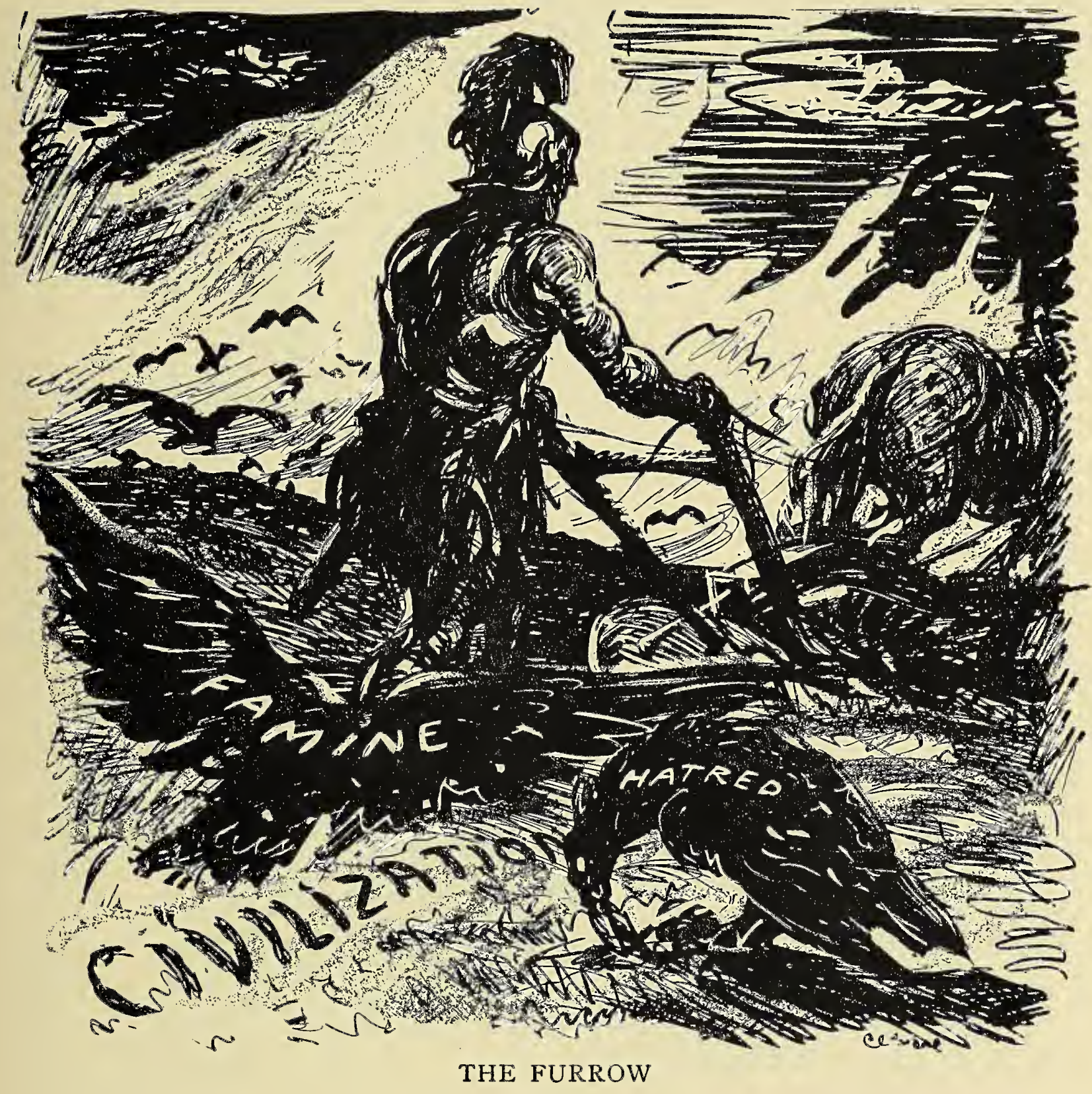





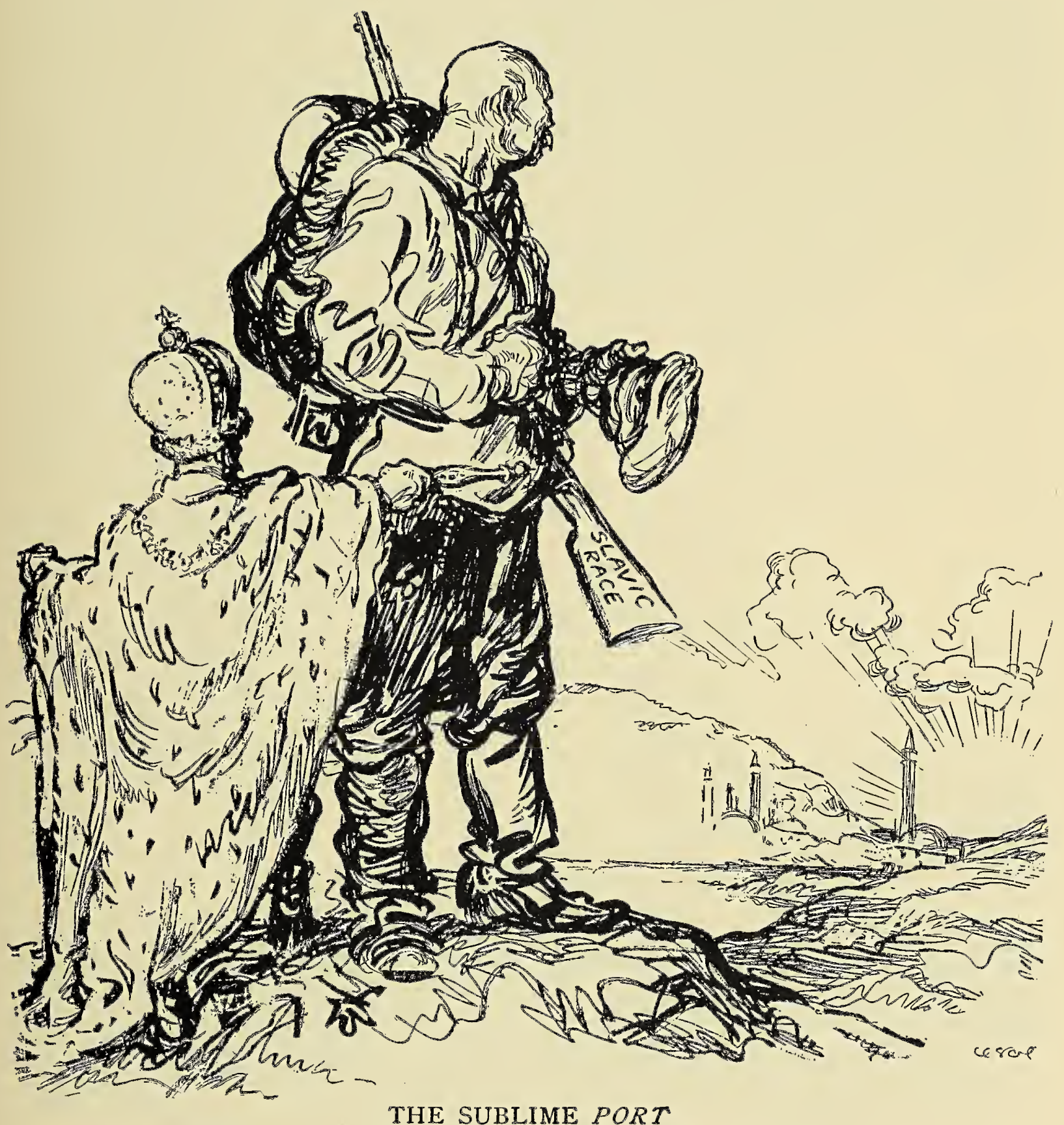





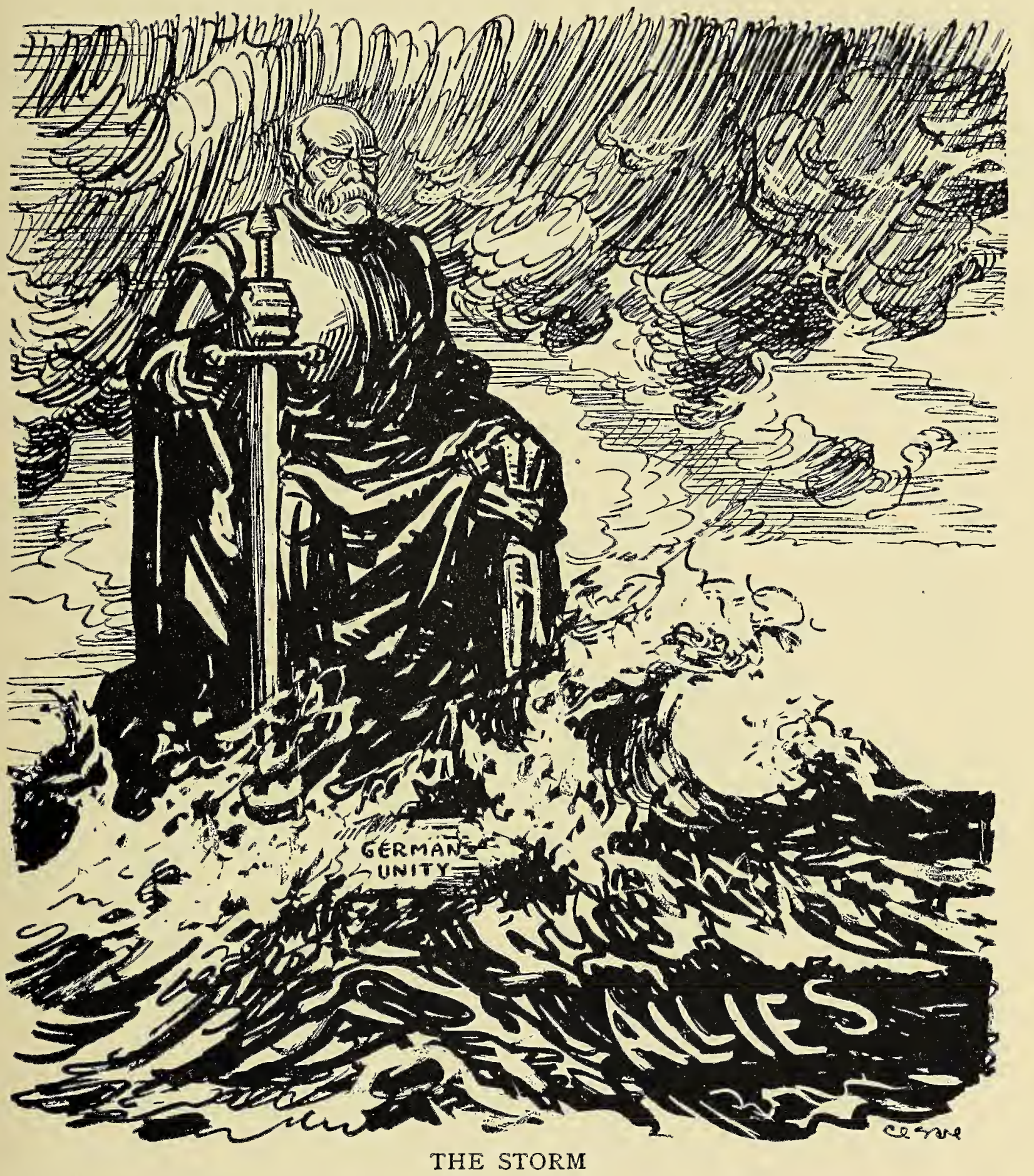

[53] 



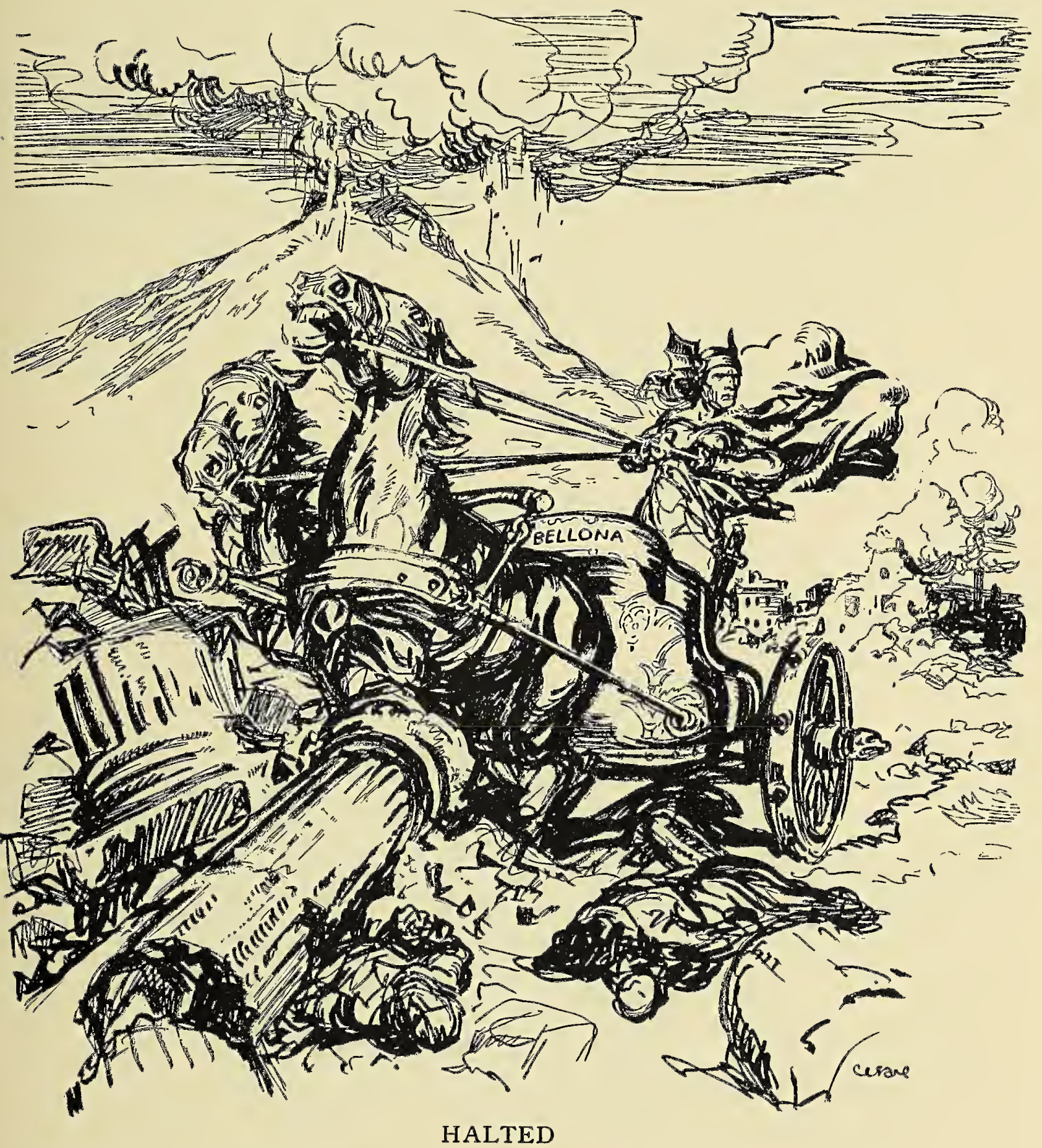

(The earthquake, January 15, 1915)

[55] 



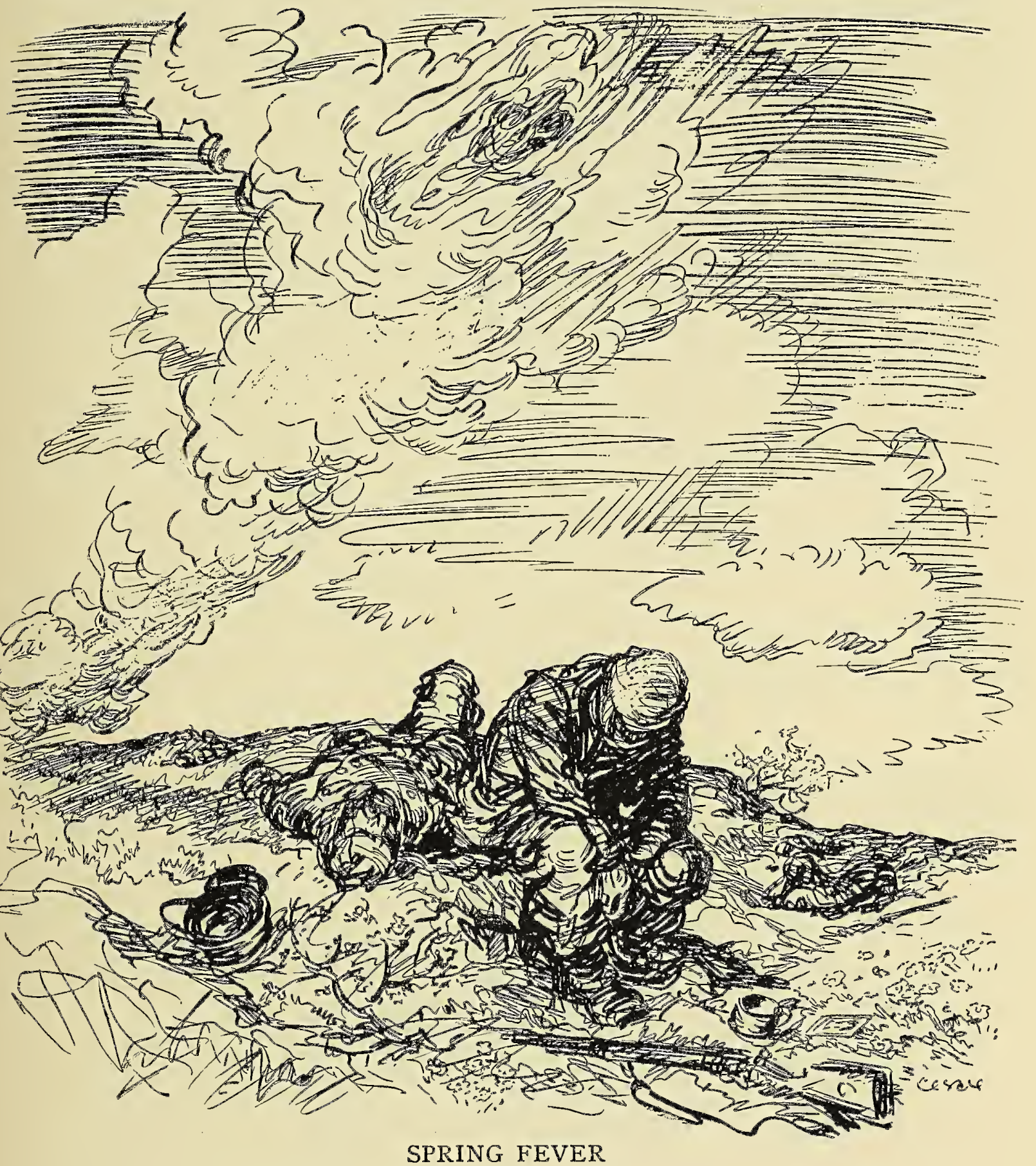

[57] 


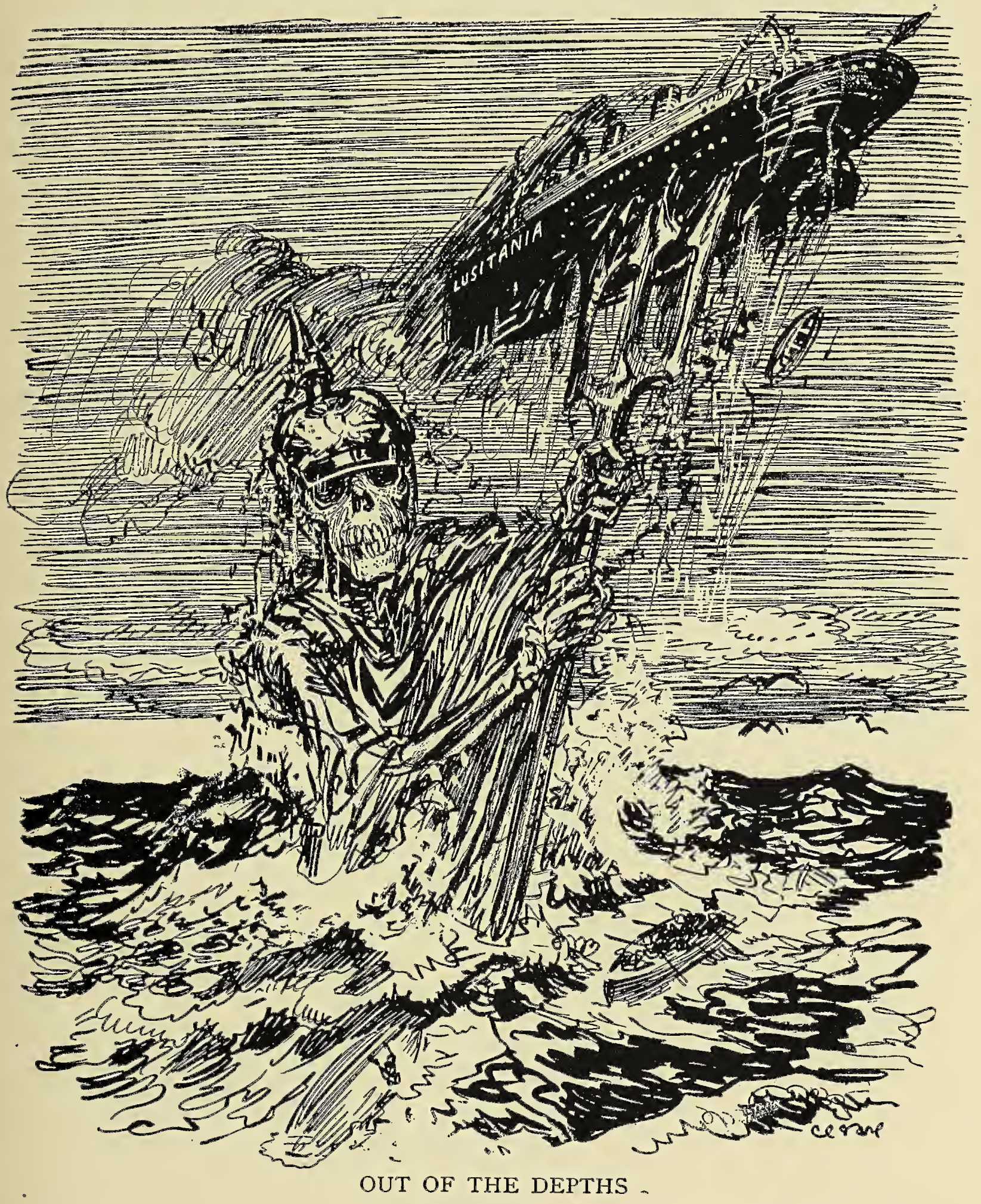

[59] 



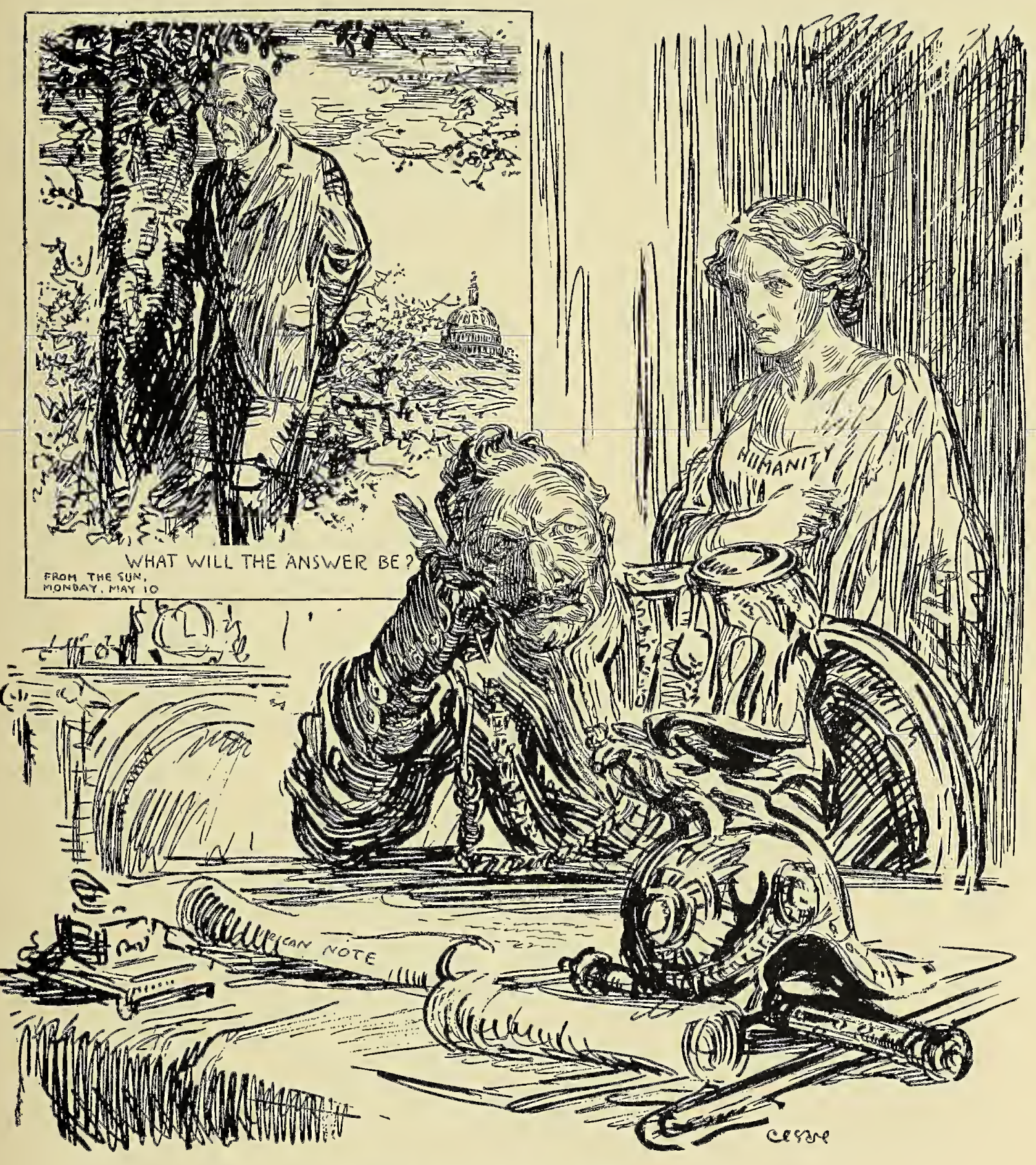

THE LUSITANIA CRISIS 

$\Rightarrow 2+2=2-2=0$

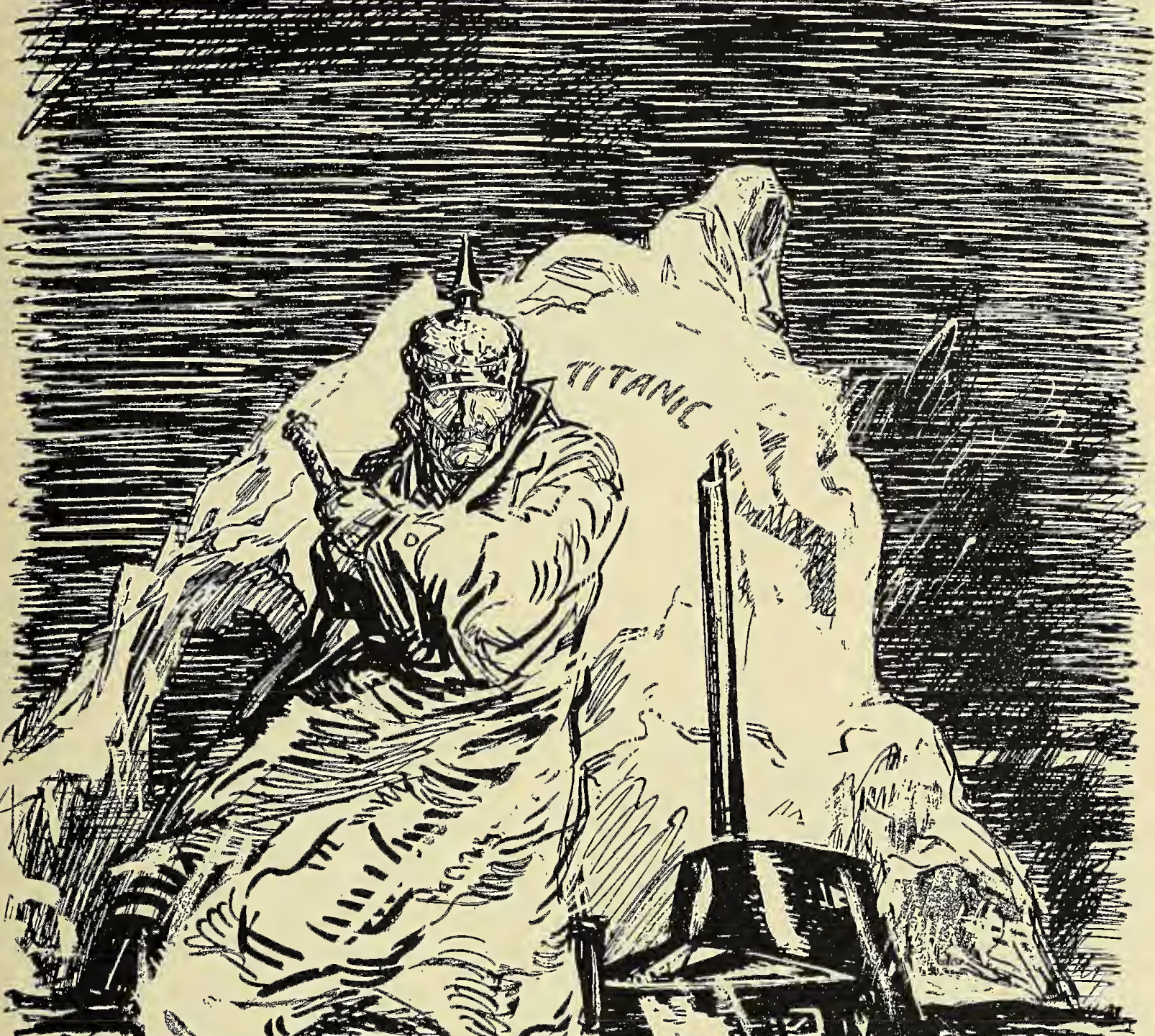

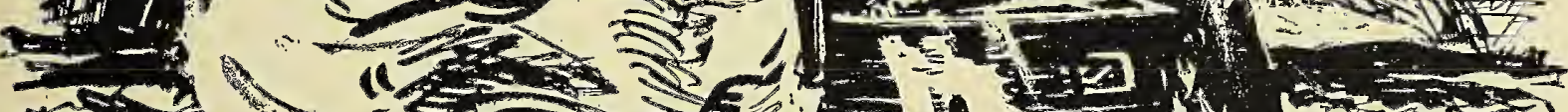

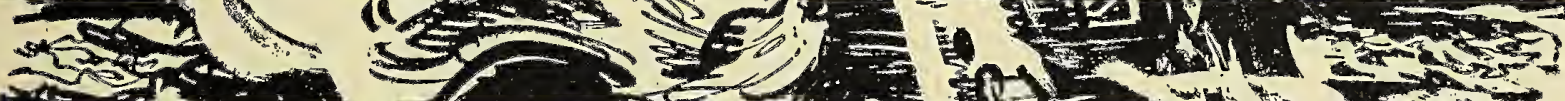

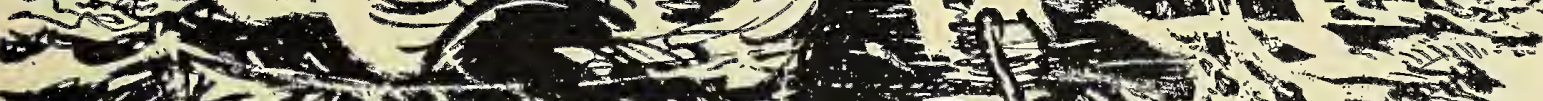

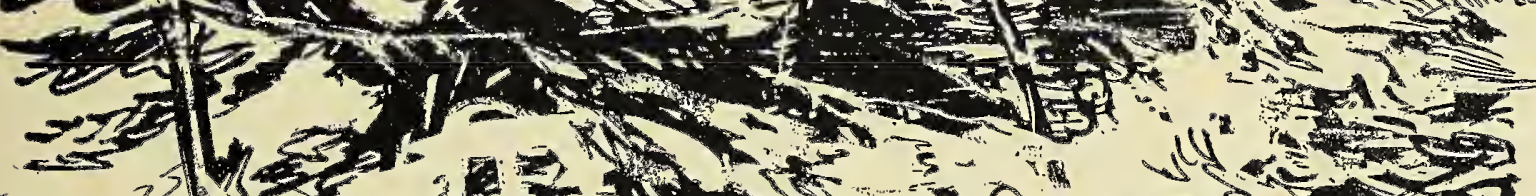
-2)

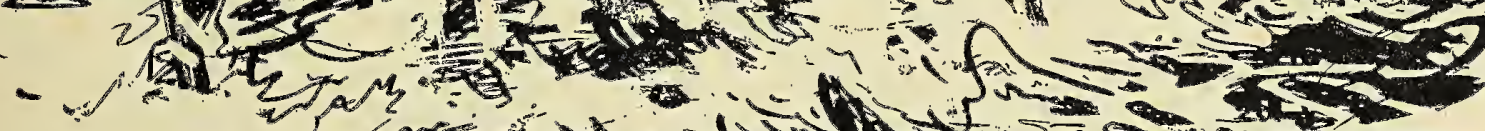

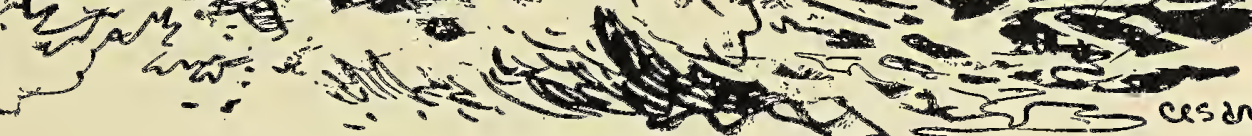

COLD AS THE ICEBERG

(After the siuking of the Lusitania, 1915)

[63] 


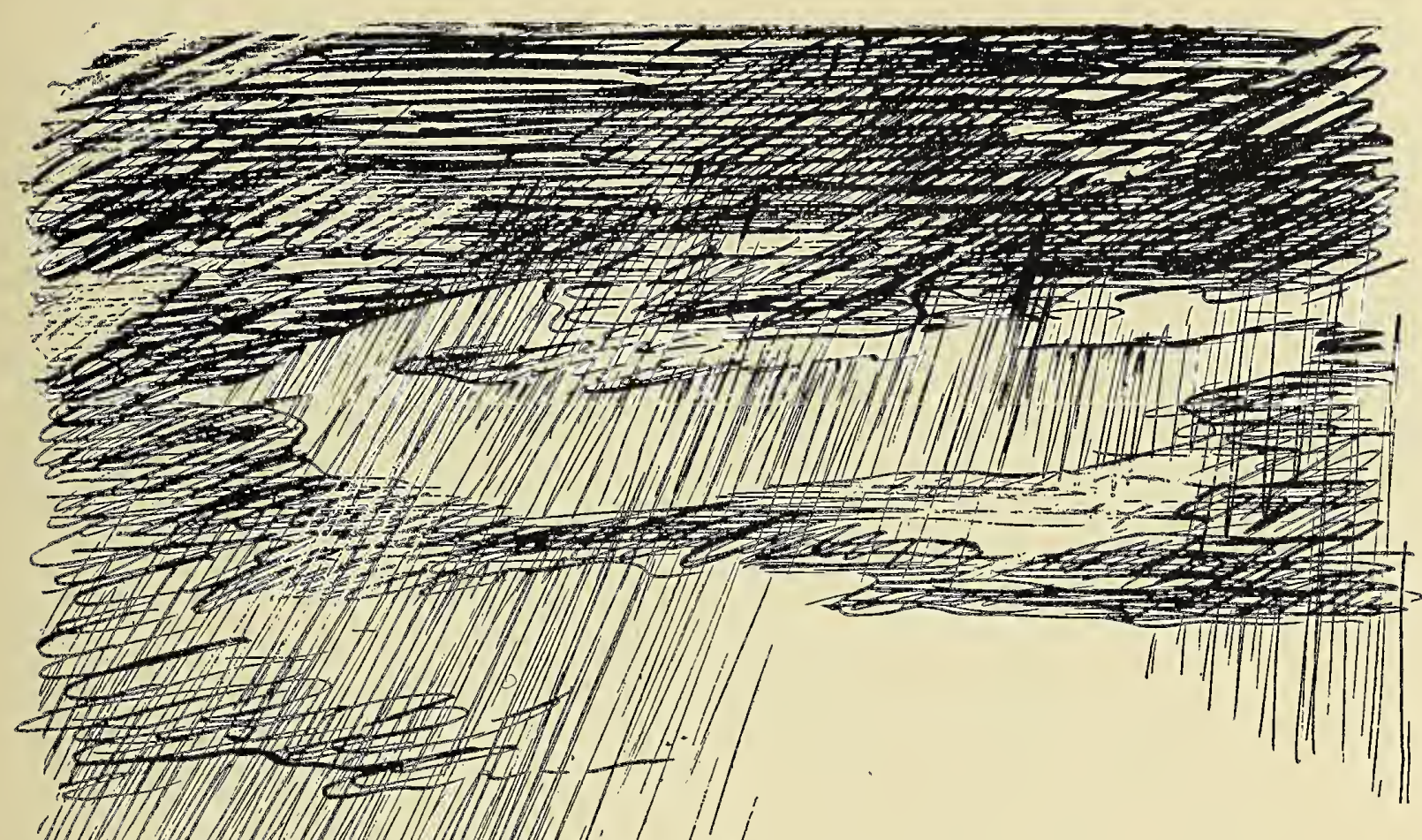





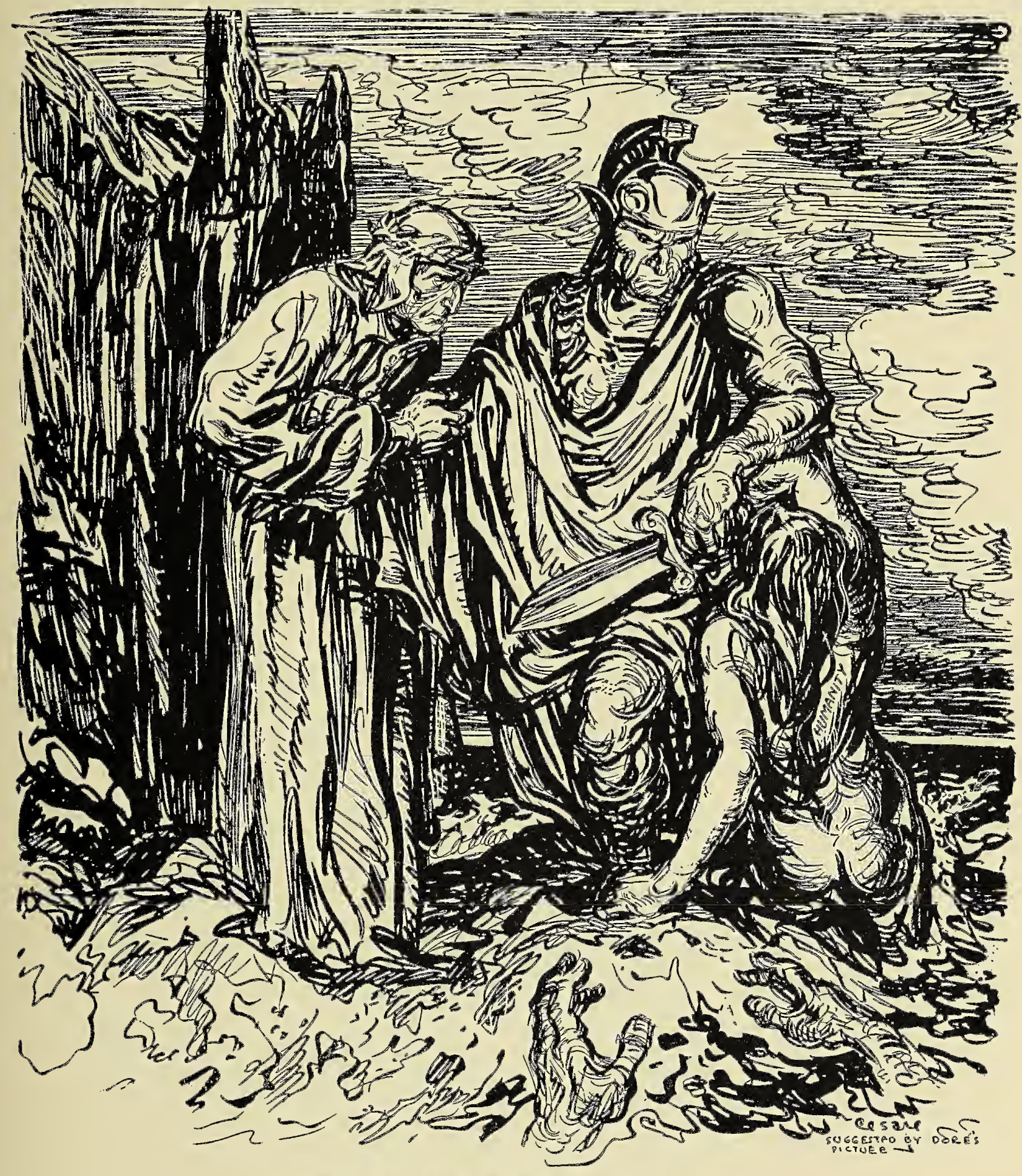

THE FIFTH CIRCLE OF HELL

"Away ! Down there to the other dogs!" 



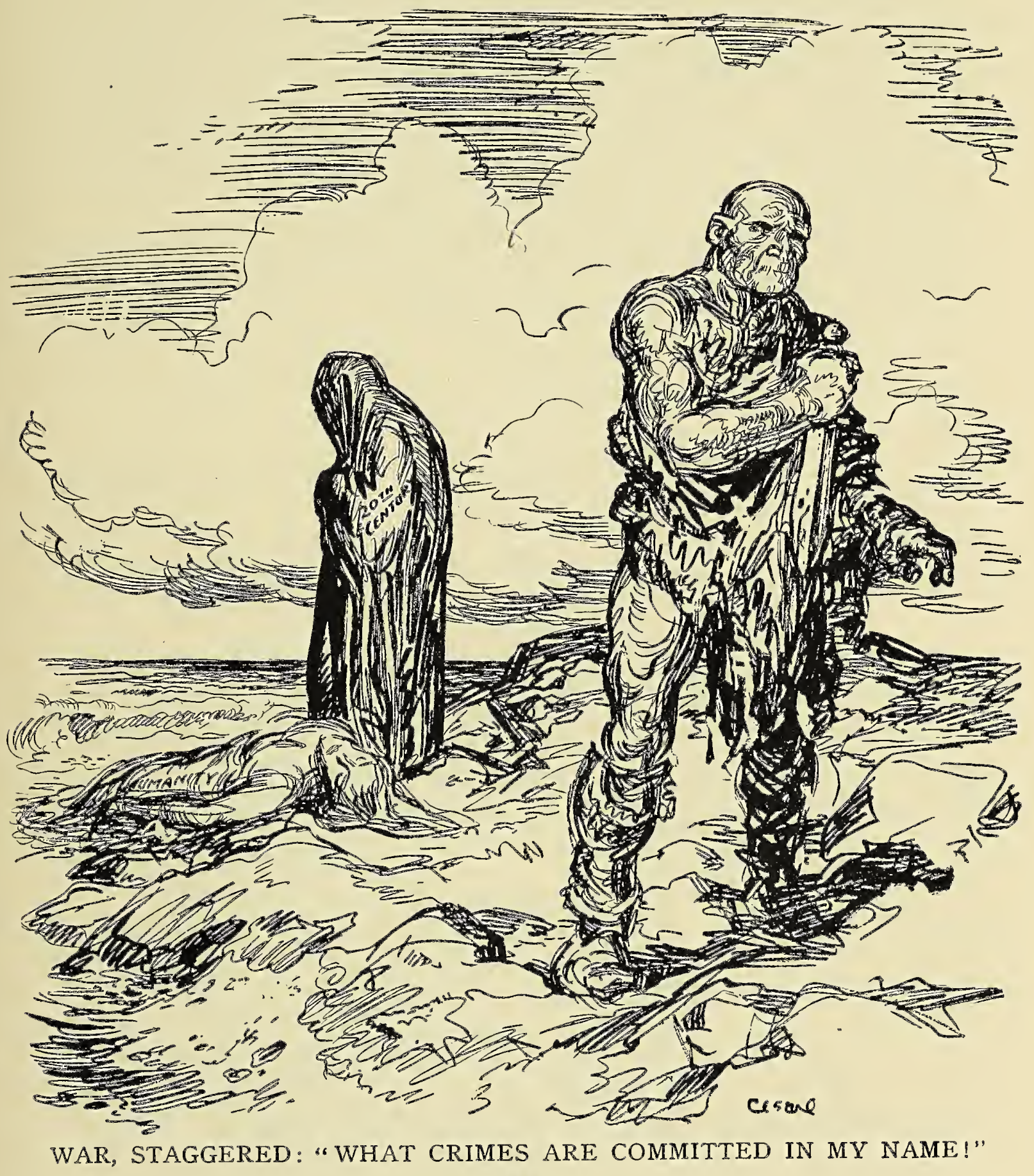





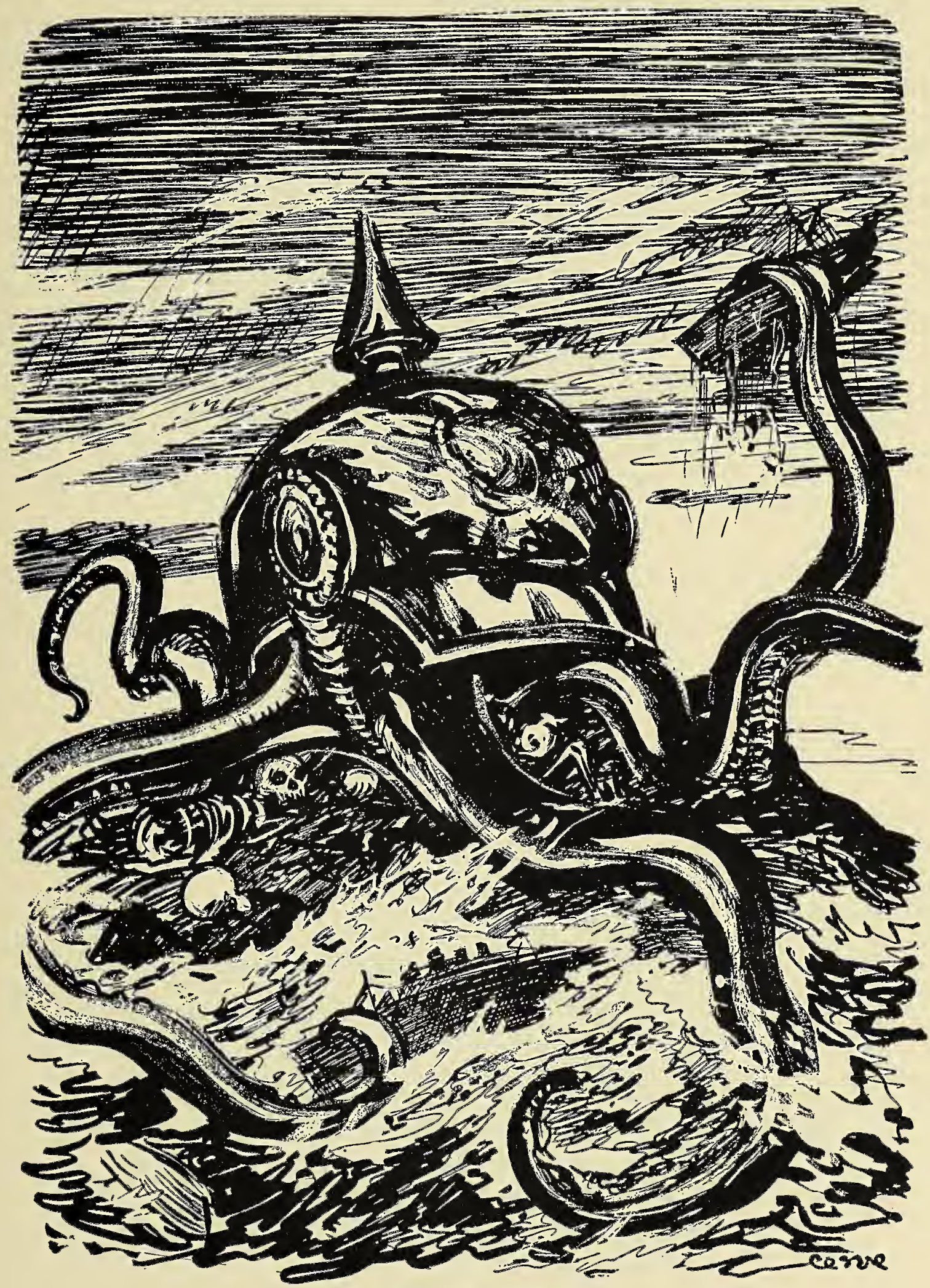

THE OCTOPUS 
. 


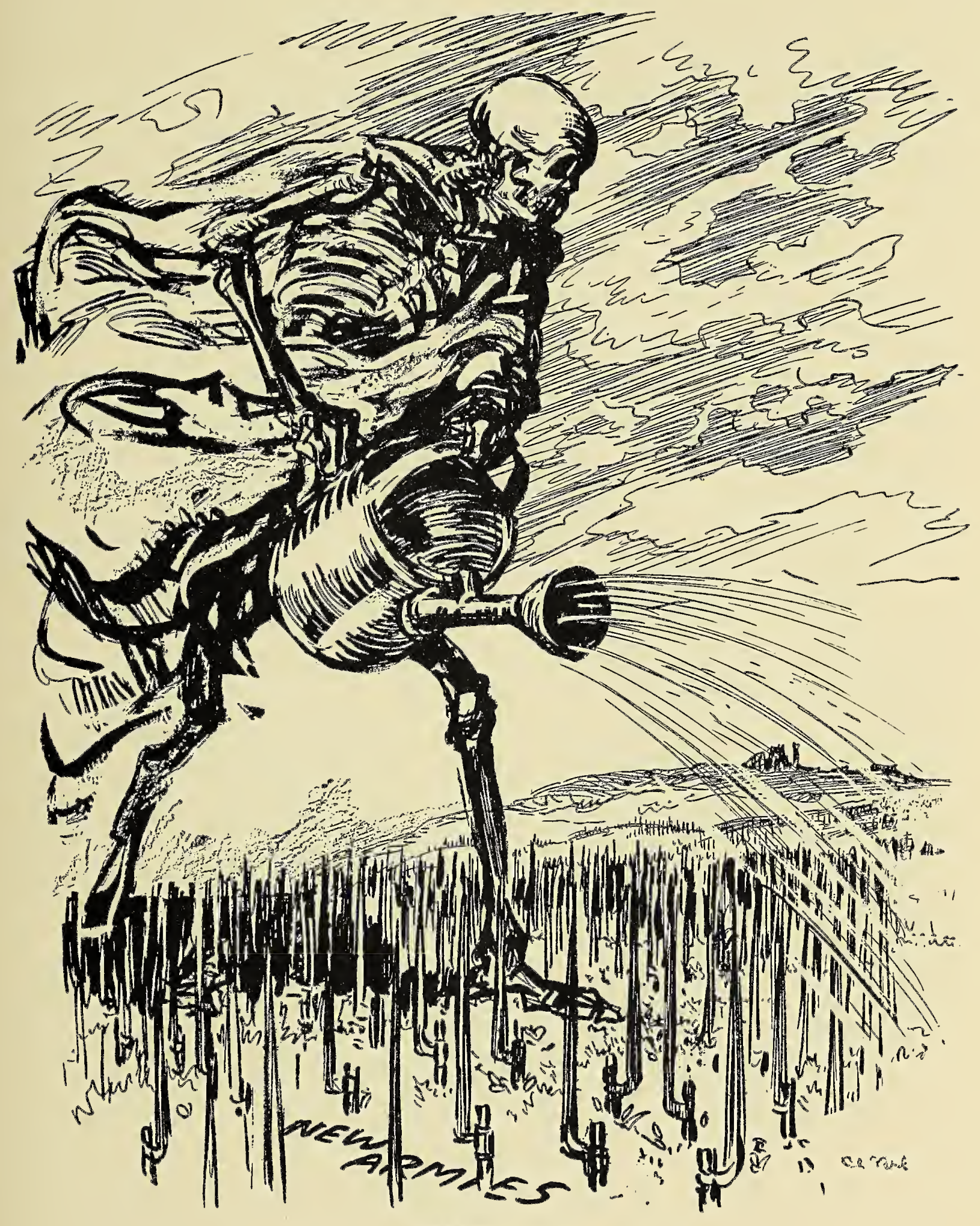

SPRING, I9I5 



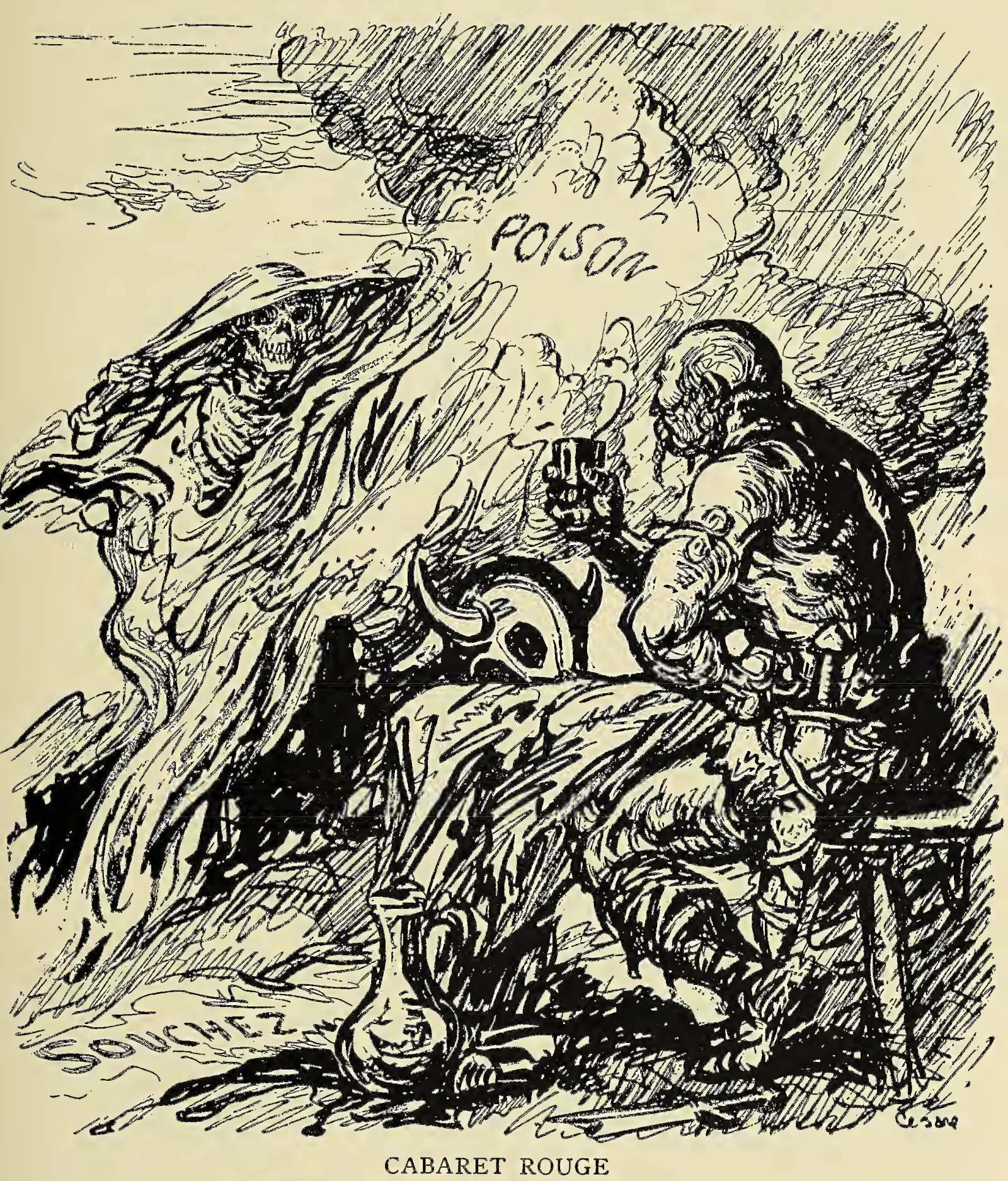

(The Germans capture Cabaret Rouge, June 12, 1915) 


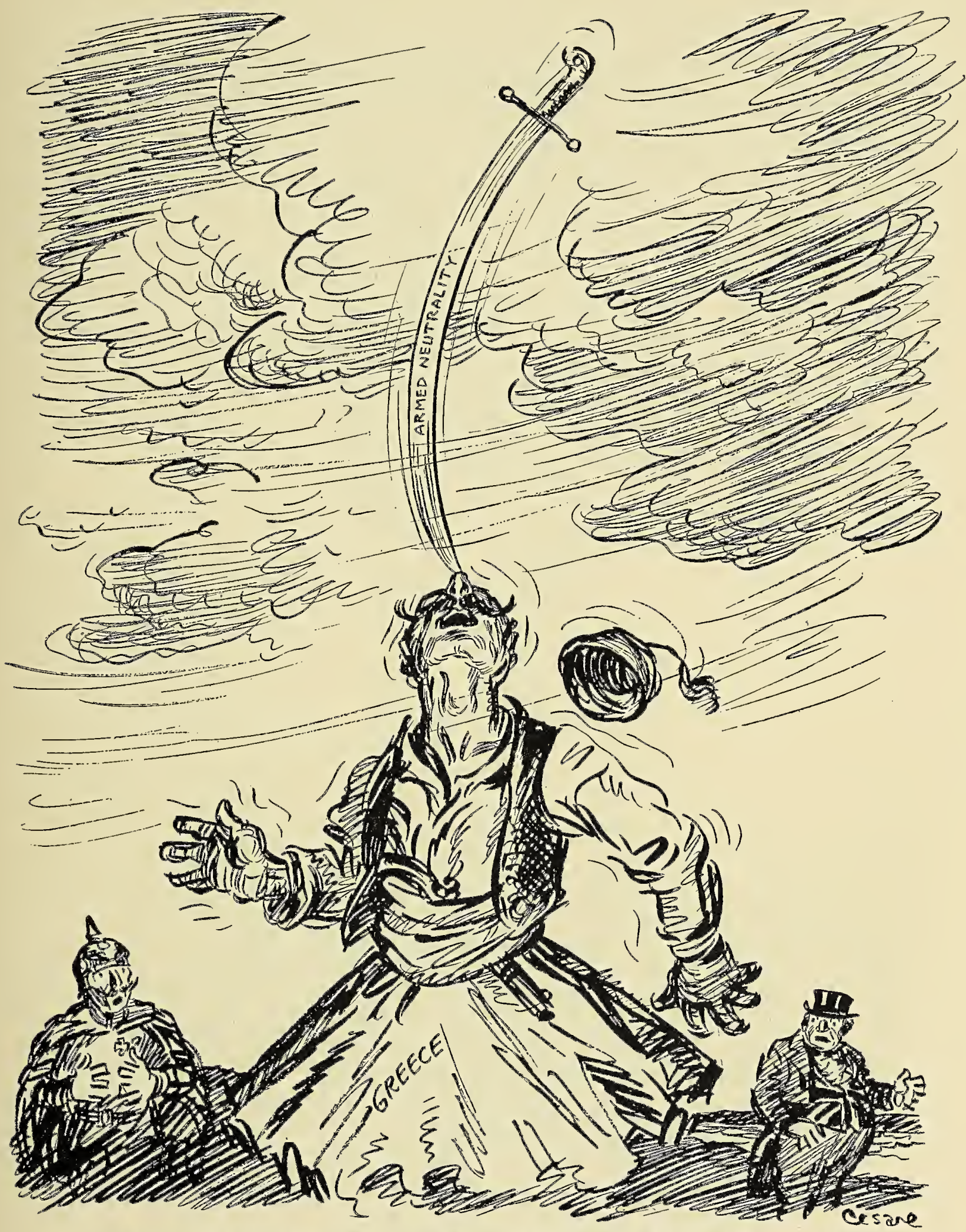

"VERY CLEVER, BUT HOW LONG CAN HE KEEP IT THERE?" 



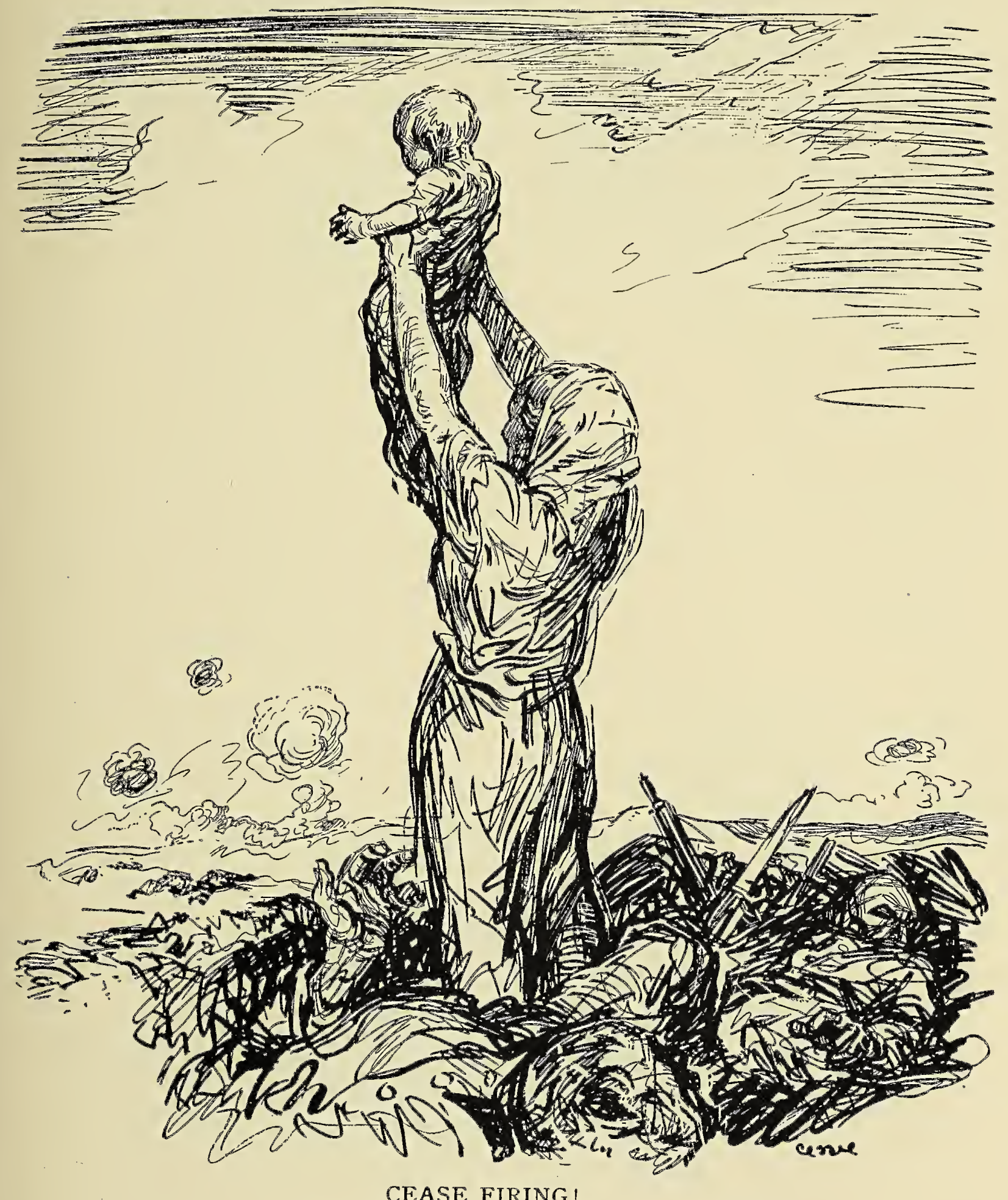

CEASE FIRING! 


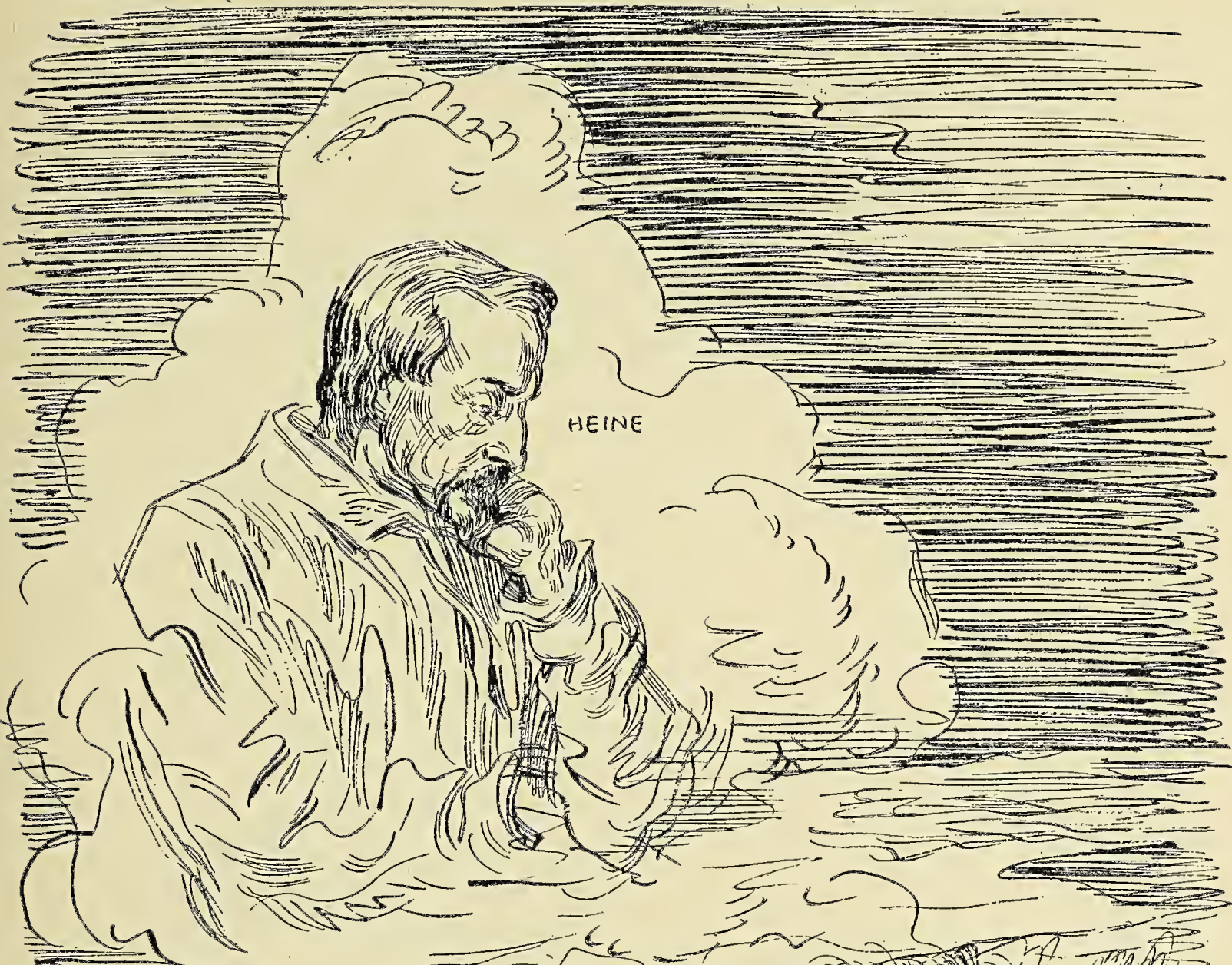
दे $\rightarrow 3$ ?

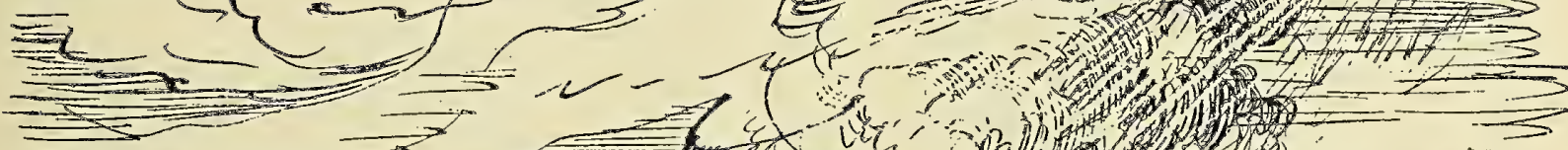

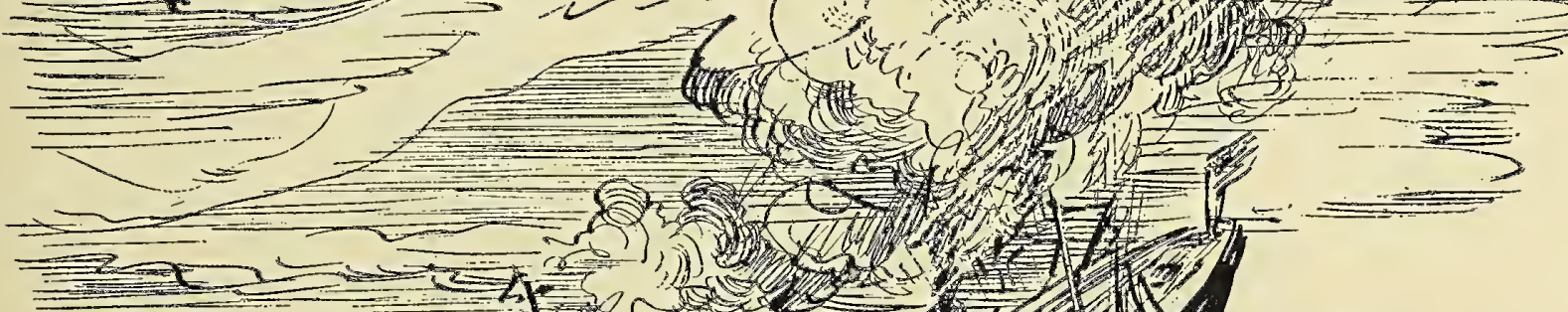

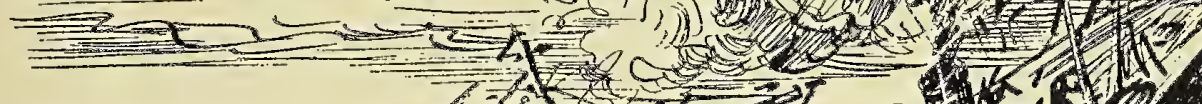

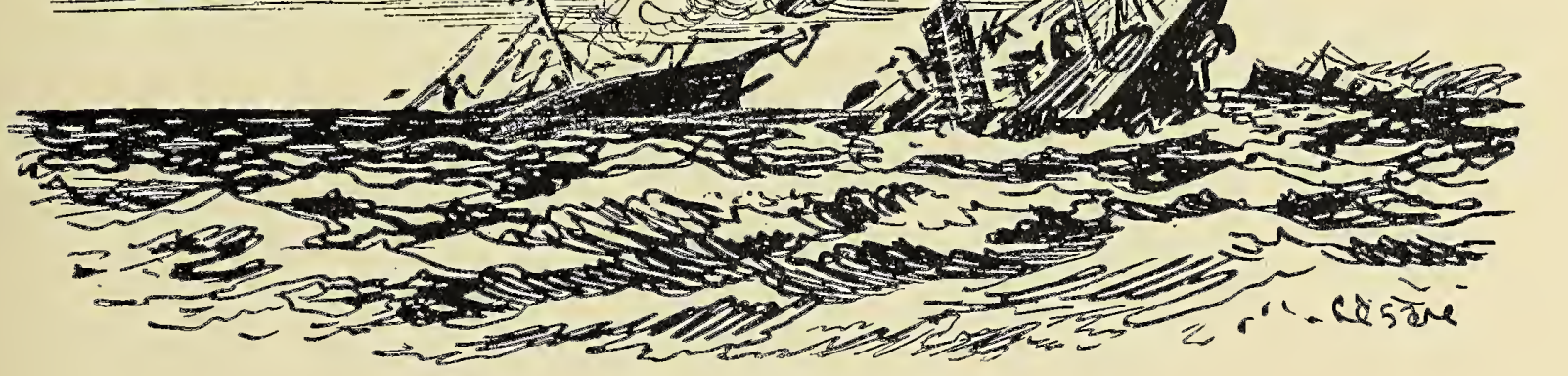

THE SPIRIT OF ' 48

"Ich weiss nicht was soll es bedeuten"

[ 8 1 1 ] 



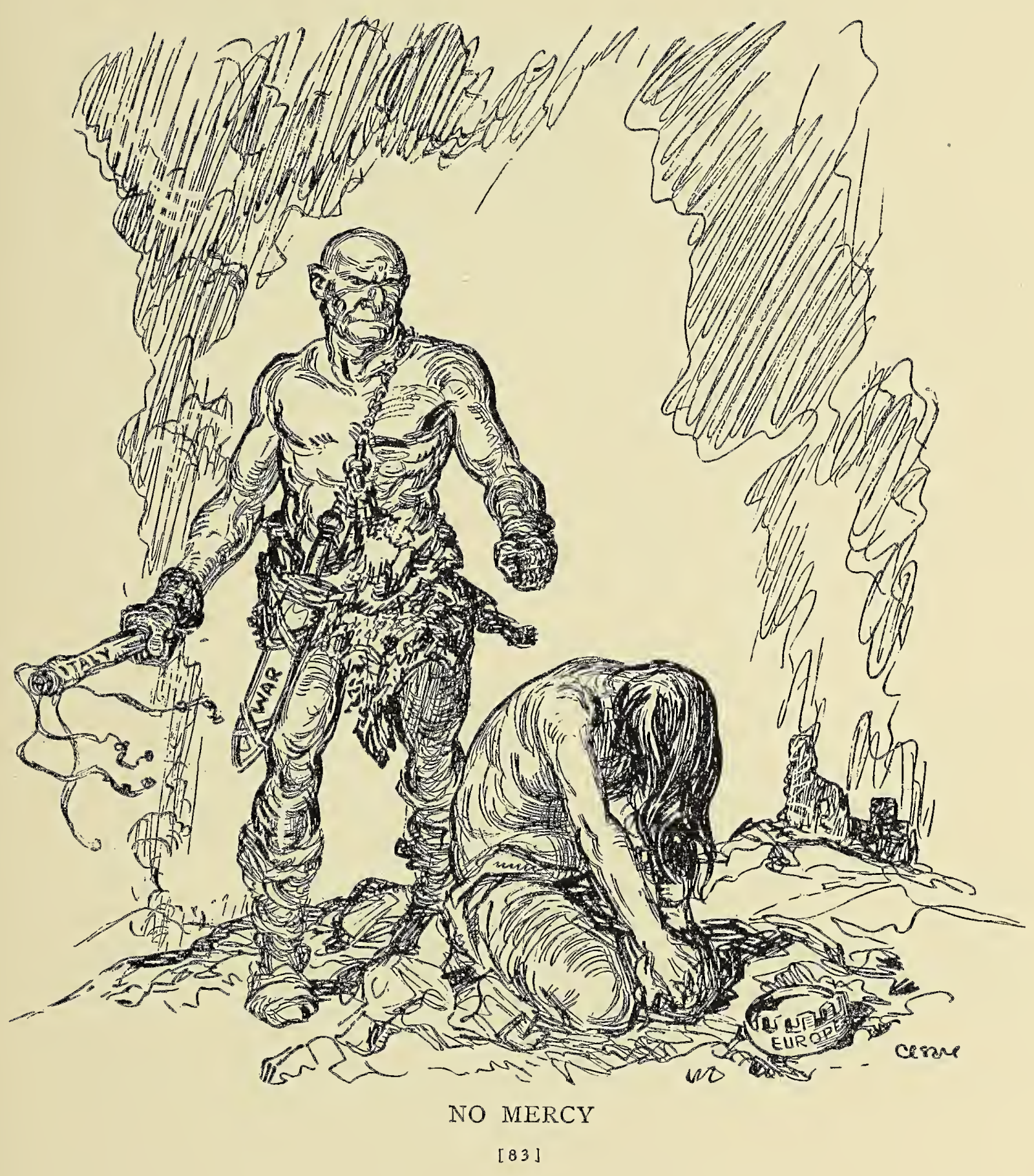




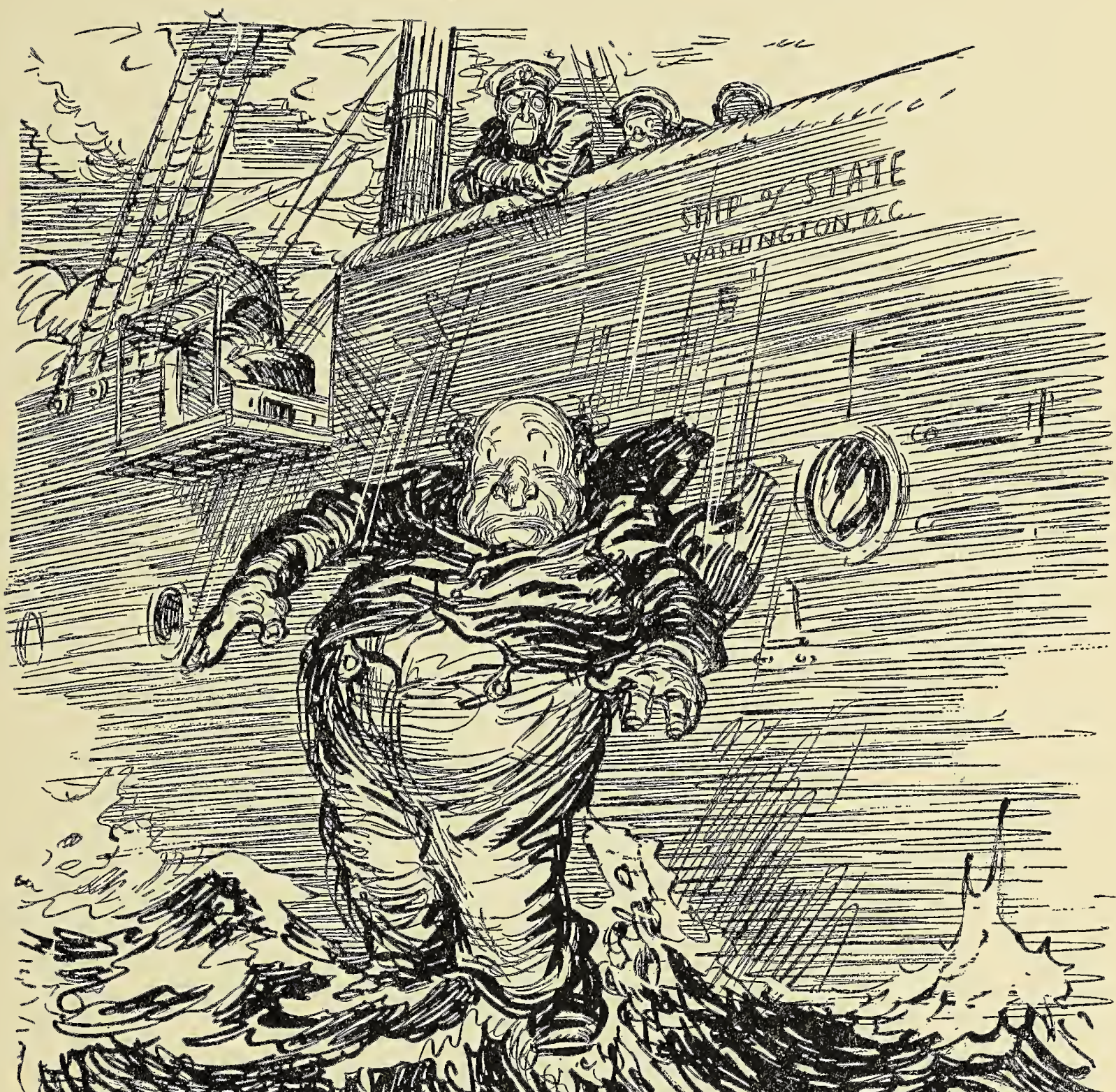

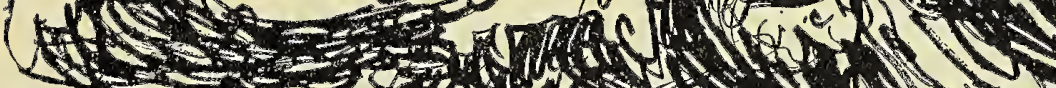

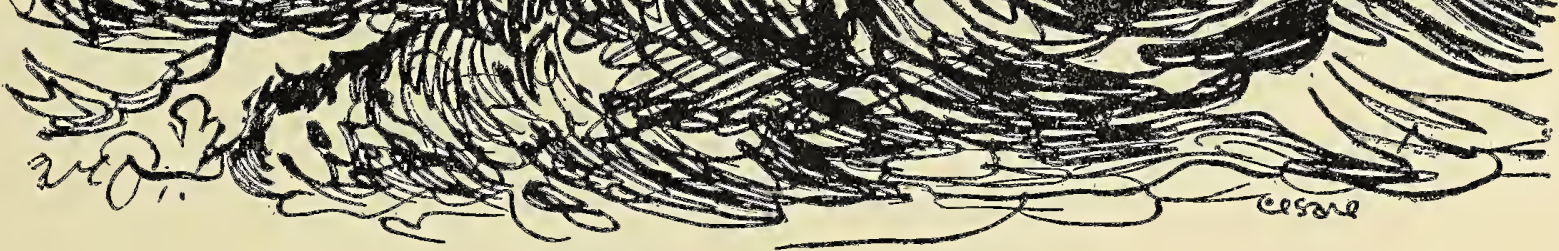

DROPPING THE PILOT 



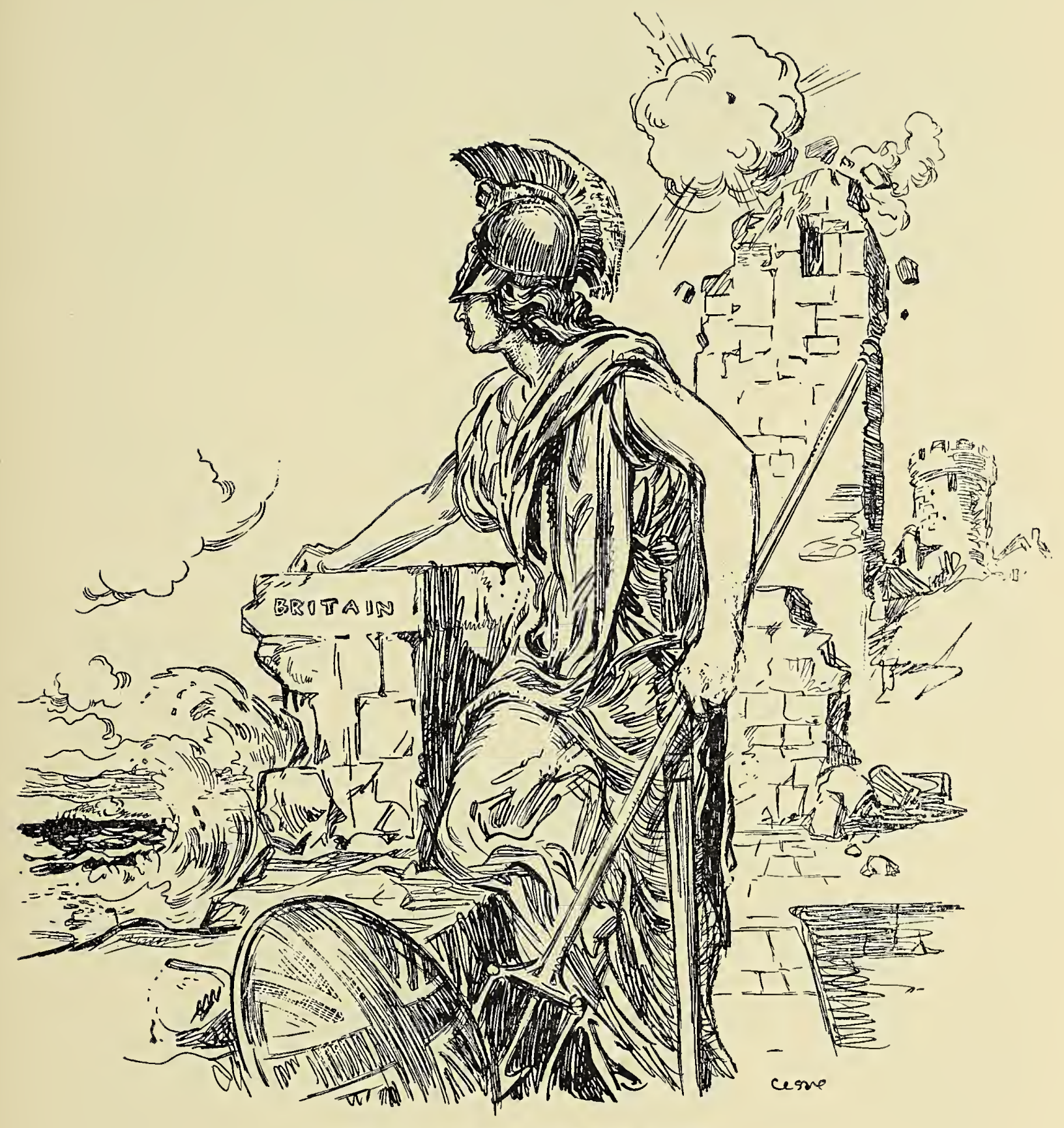

IN THE ENGLISHMAN'S HOME

(The British Isles are bombarded. - Cable dispatch)

[ 87 7] 



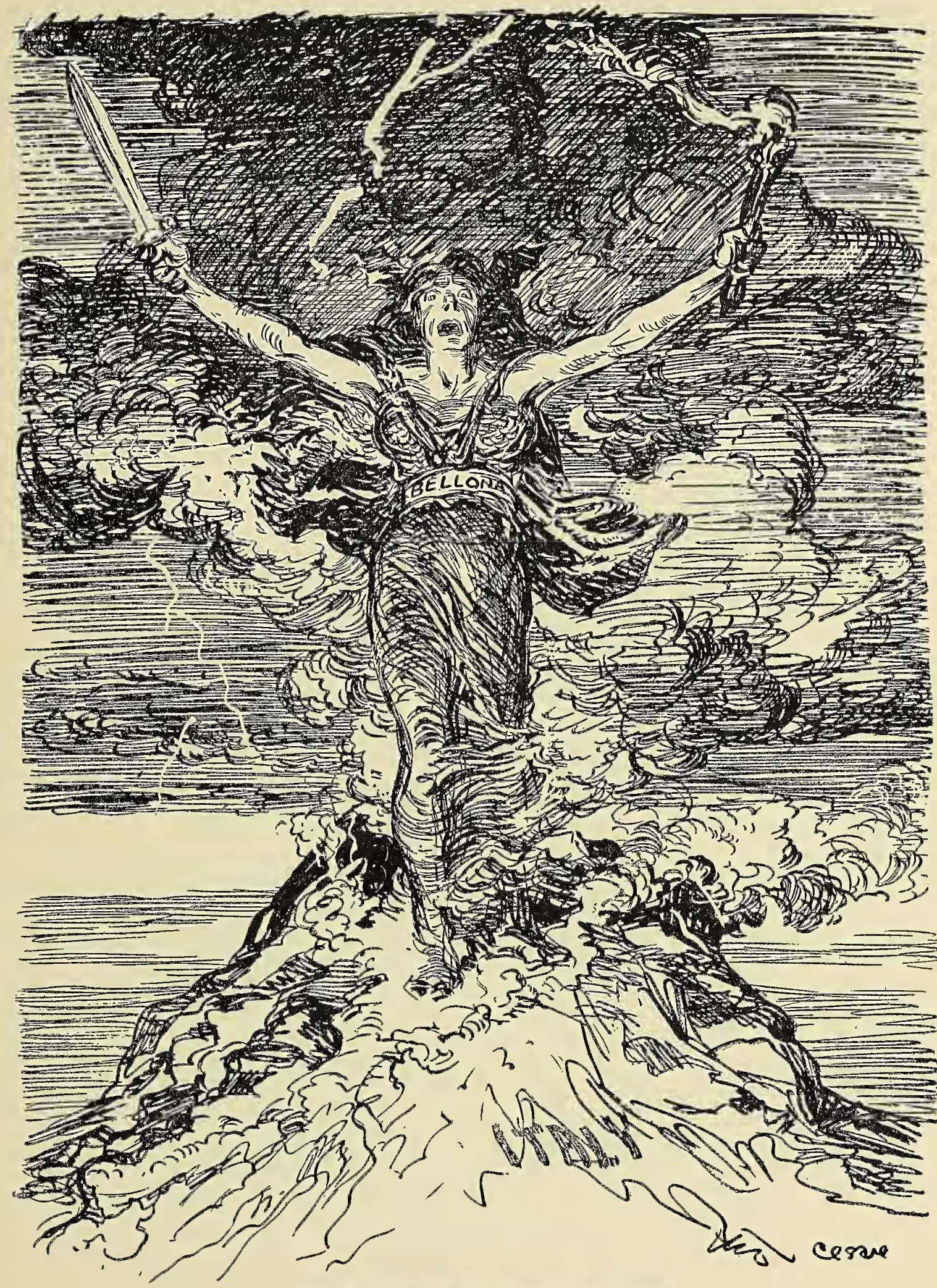

THE VOICE OF THE PEOPLE

(The Italian people clamor for war. - Cable dispatch) 



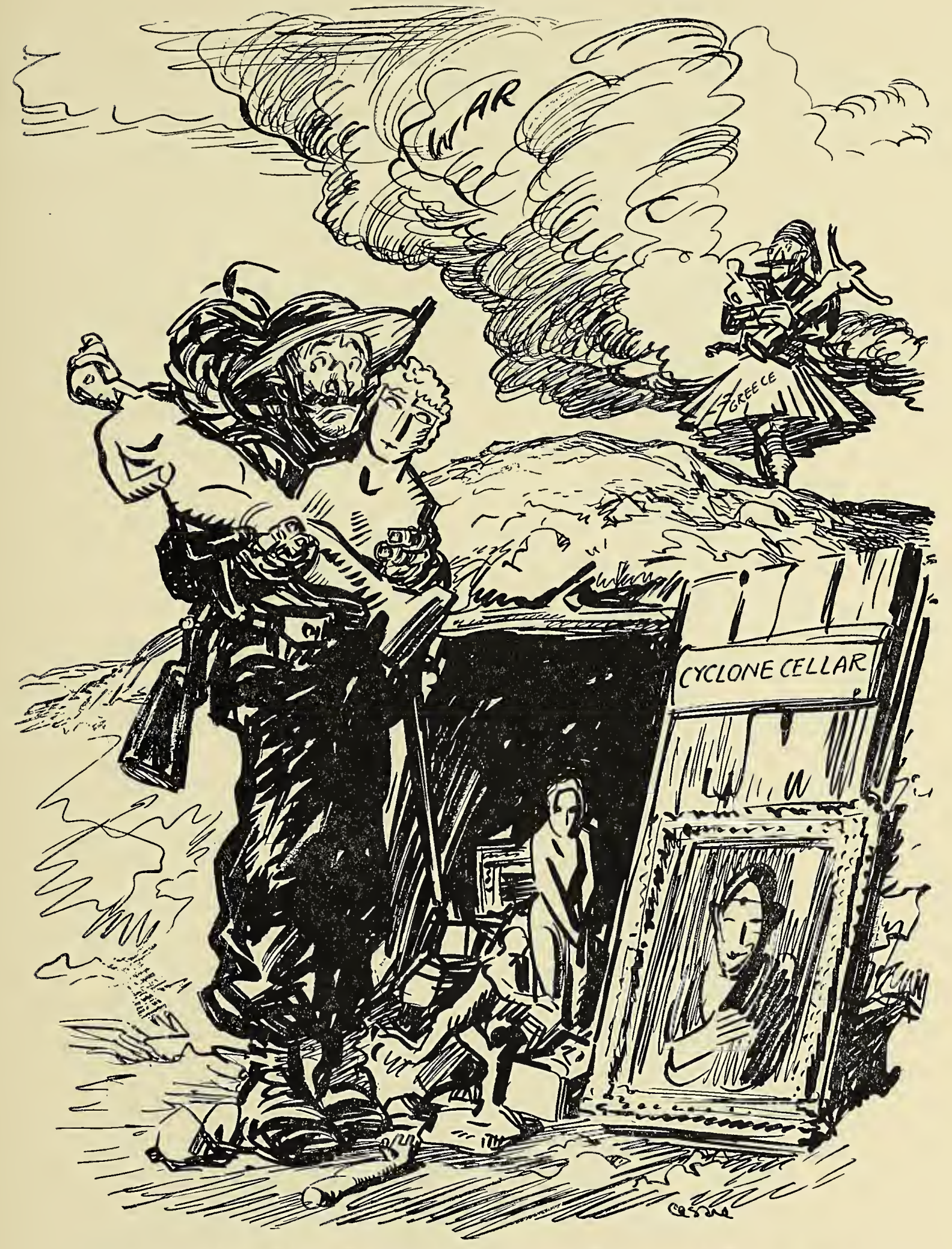

“THE GLORY THAT WAS GREECE AND THE GRANDEUR THAT WAS ROME" 



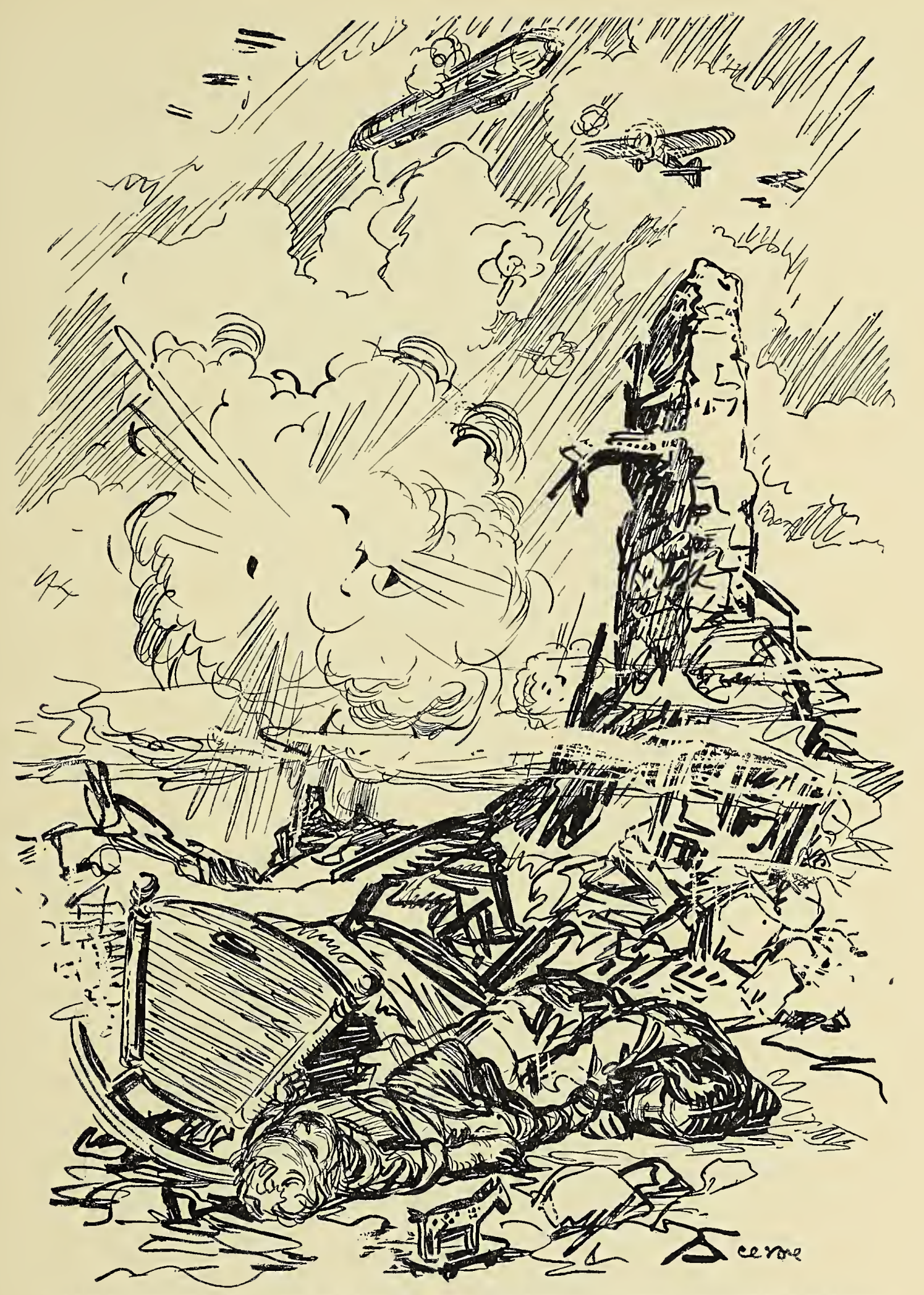

"INASMUCH AS YE HAVE DONE IT UNTO ONE OF THE LEAST OF THESE, YE HAVE DONE IT UNTO ME"

(Karlsruhe bombarded by Allied aviators in retaliation. - Cable dispatch, June, 1915) 



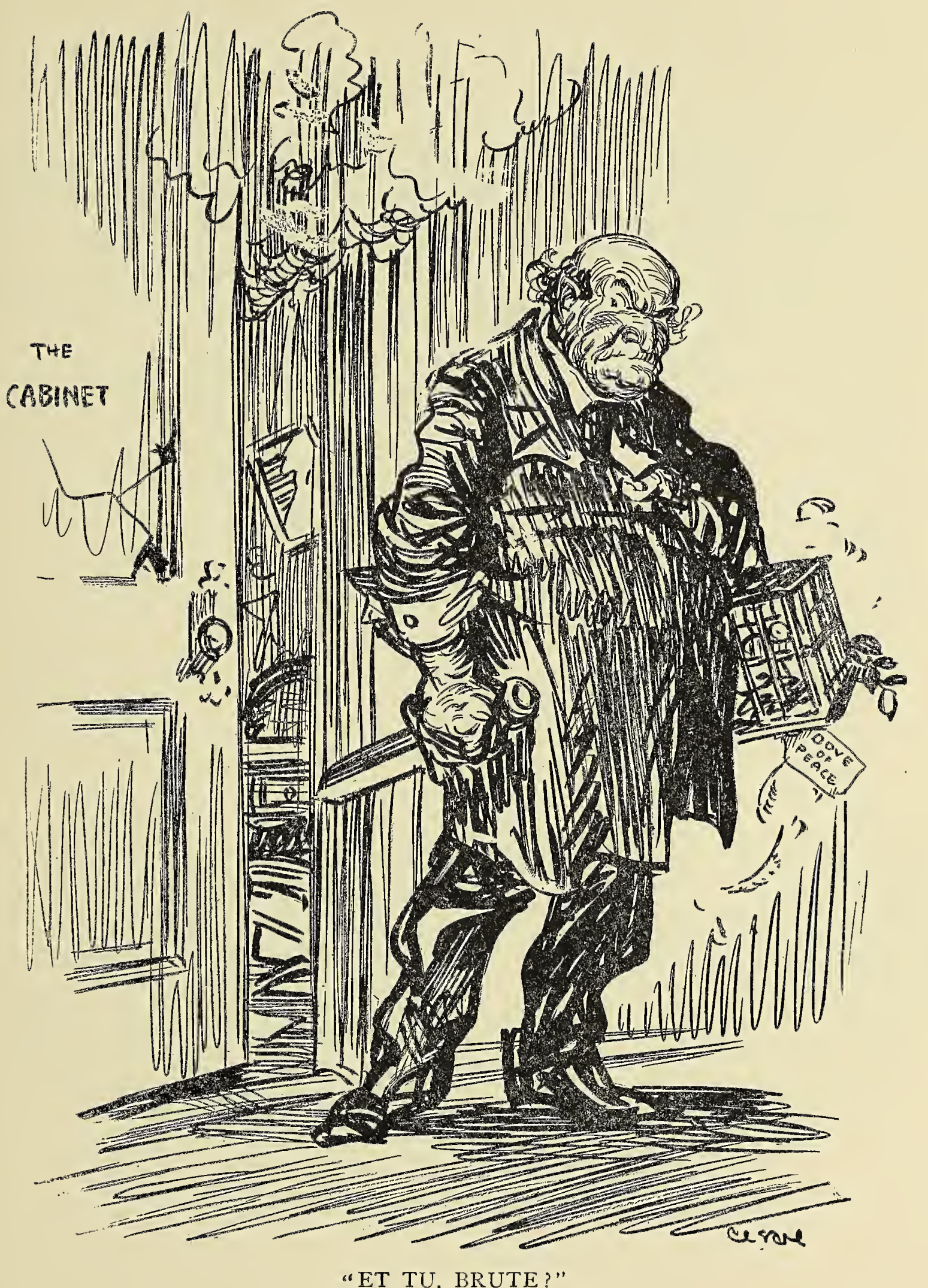





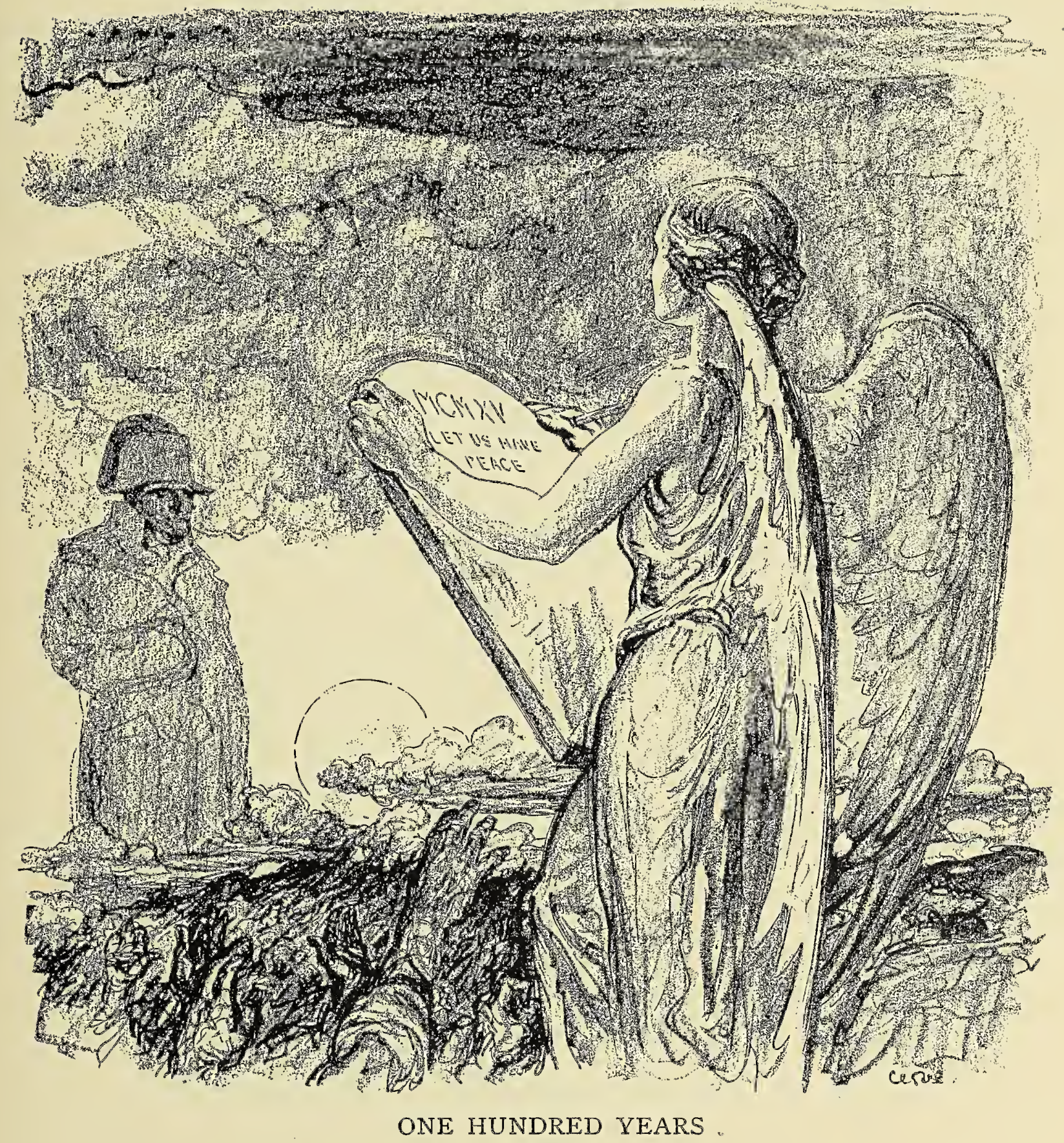

[97] 


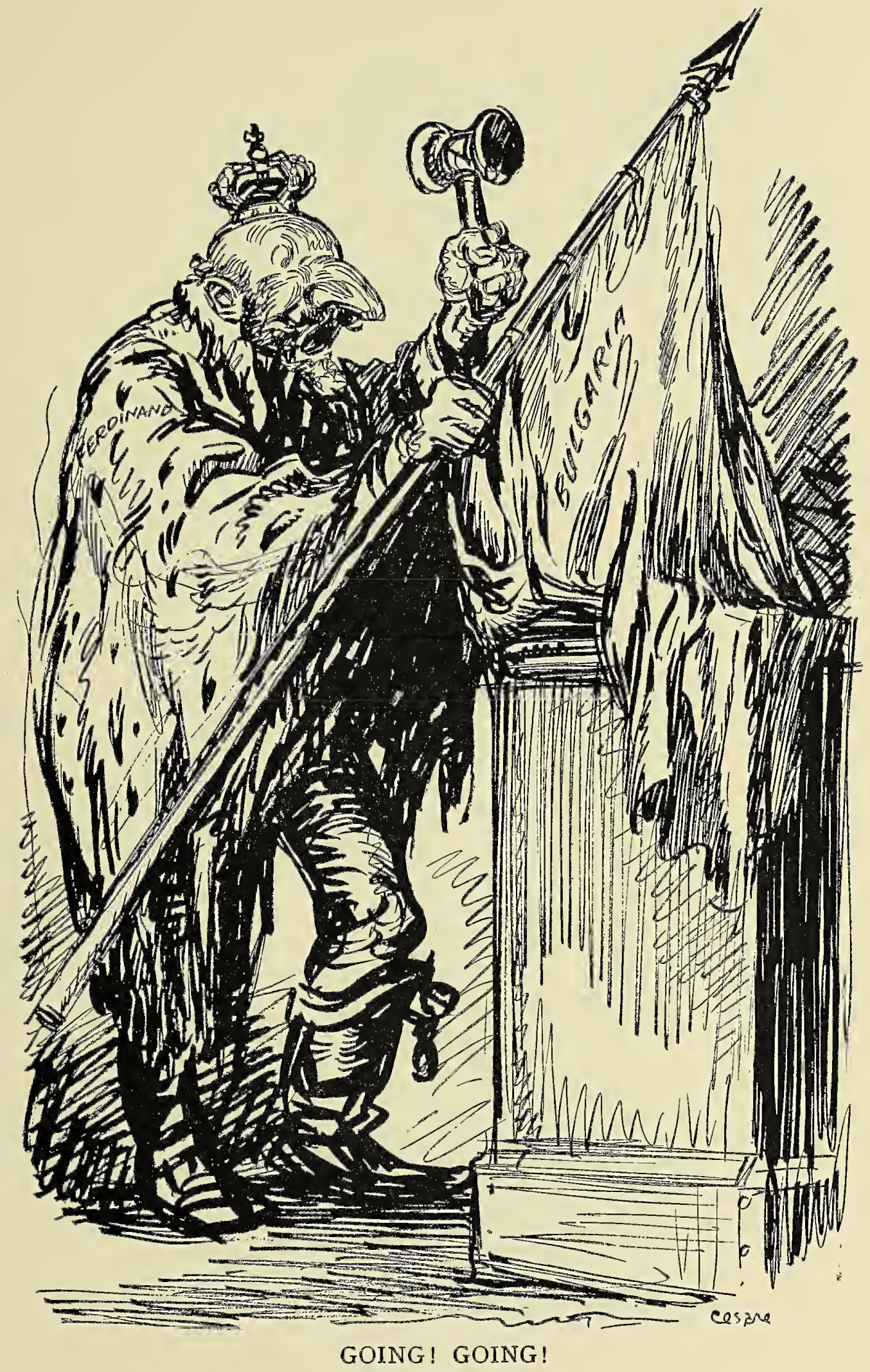

(August, 1915)

[99] 



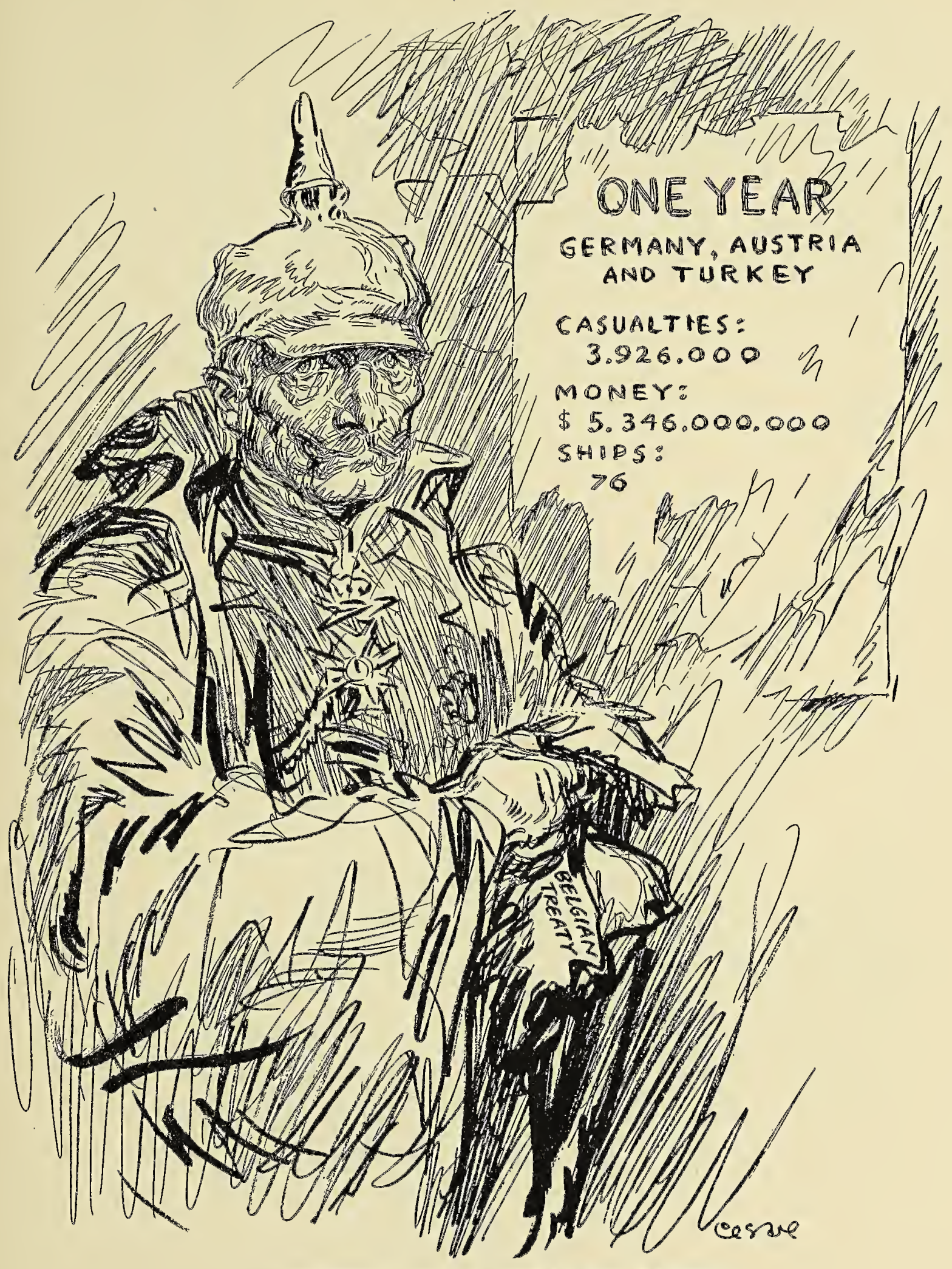

DIVIDENDS ON "A SCRAP OF PAPER" 



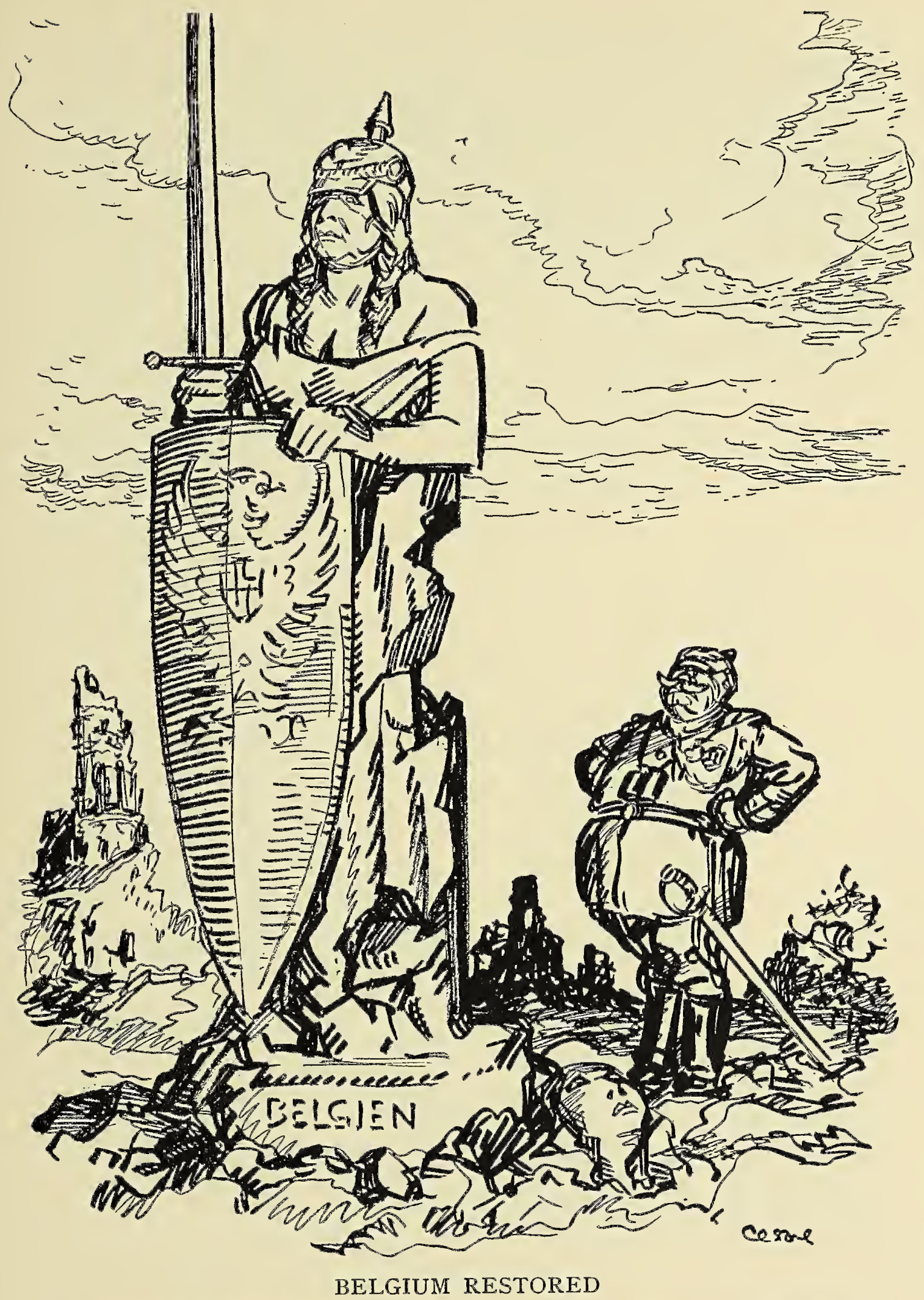

(Germany is to restore monuments and architecture damaged in last summer's invasion. - Wireless dispatch, August, 1915) 



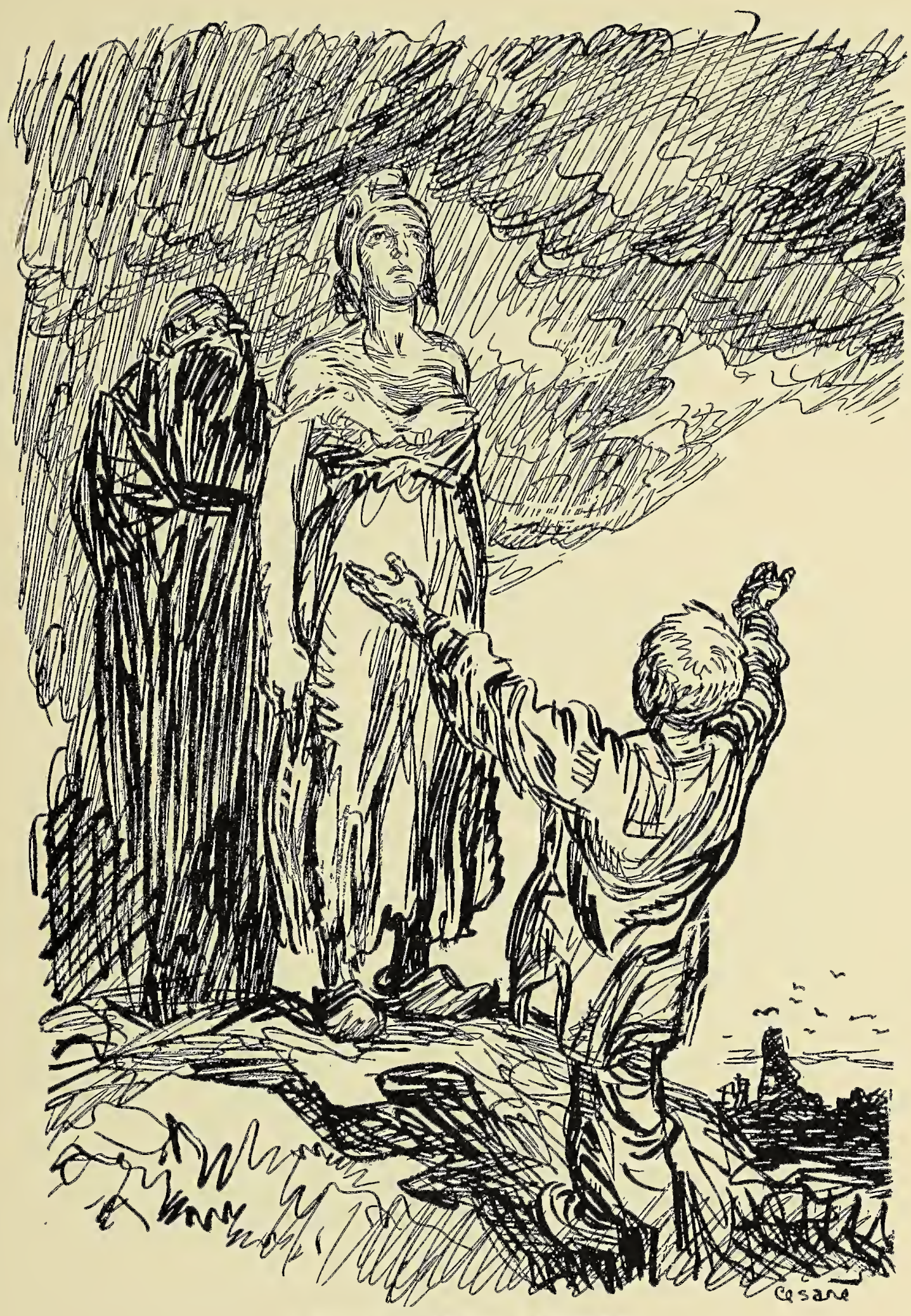

DULCIS AMOR PATRIAE

(President Poincaré, in a bill, will ask for 400,000 recruits between 18 and 19 years old - Cable dispatch, September, 1915)

$\left[\begin{array}{lll}1 & 0 & 5\end{array}\right]$ 


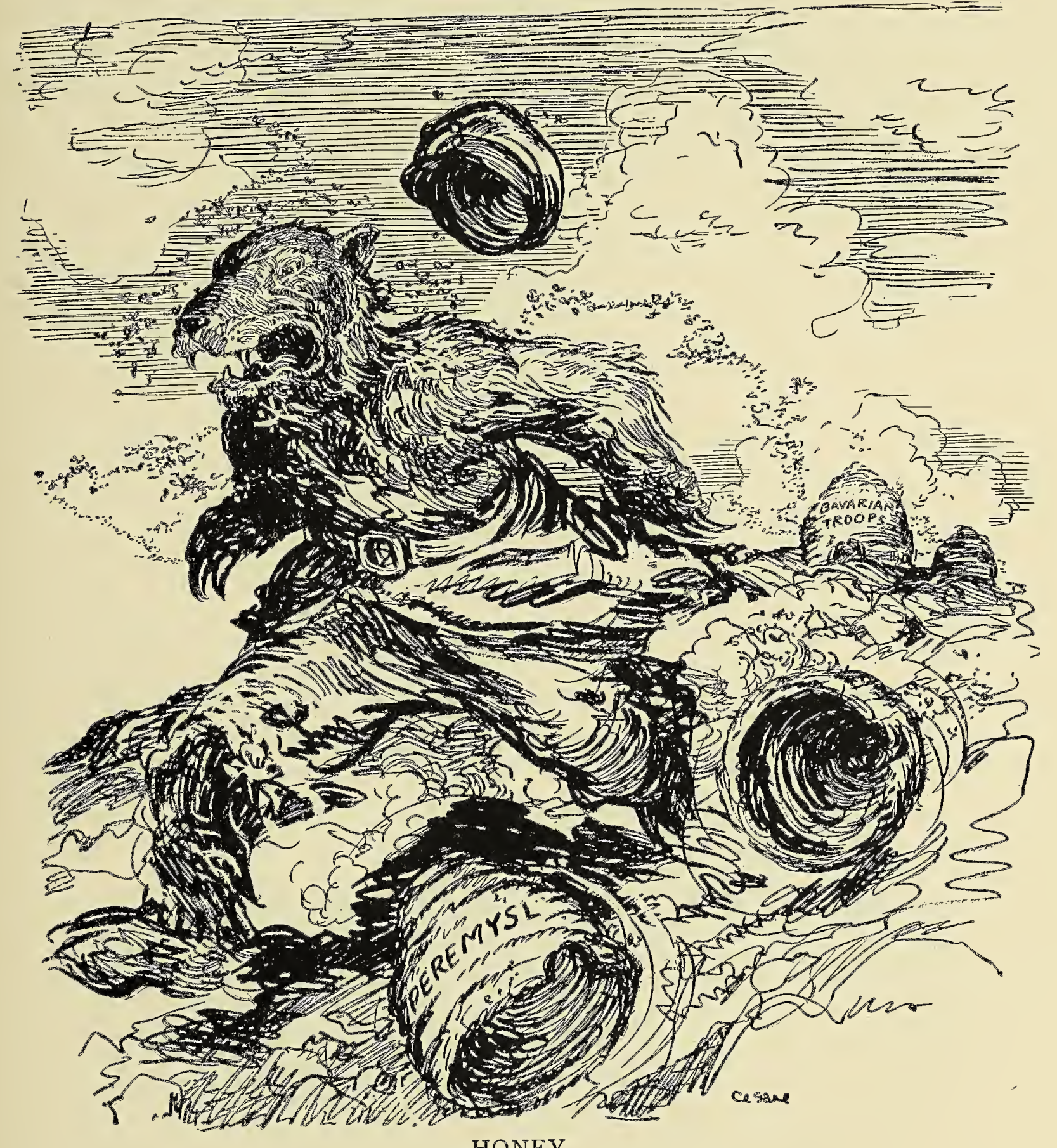

HONEY

(The Germans and Austrians recapture Peremysl, September, 1915)

[ 107$]$ 



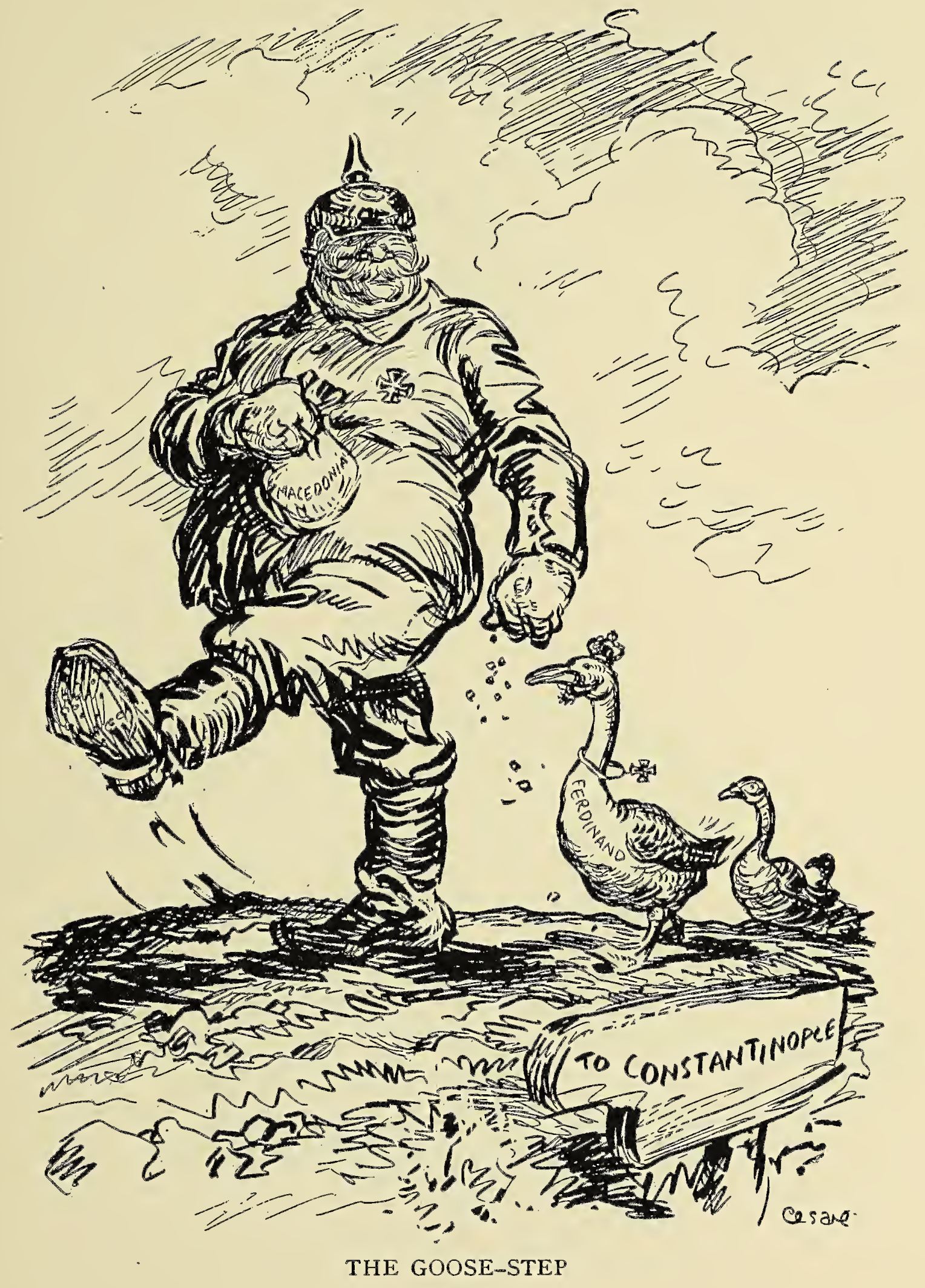

[109] 



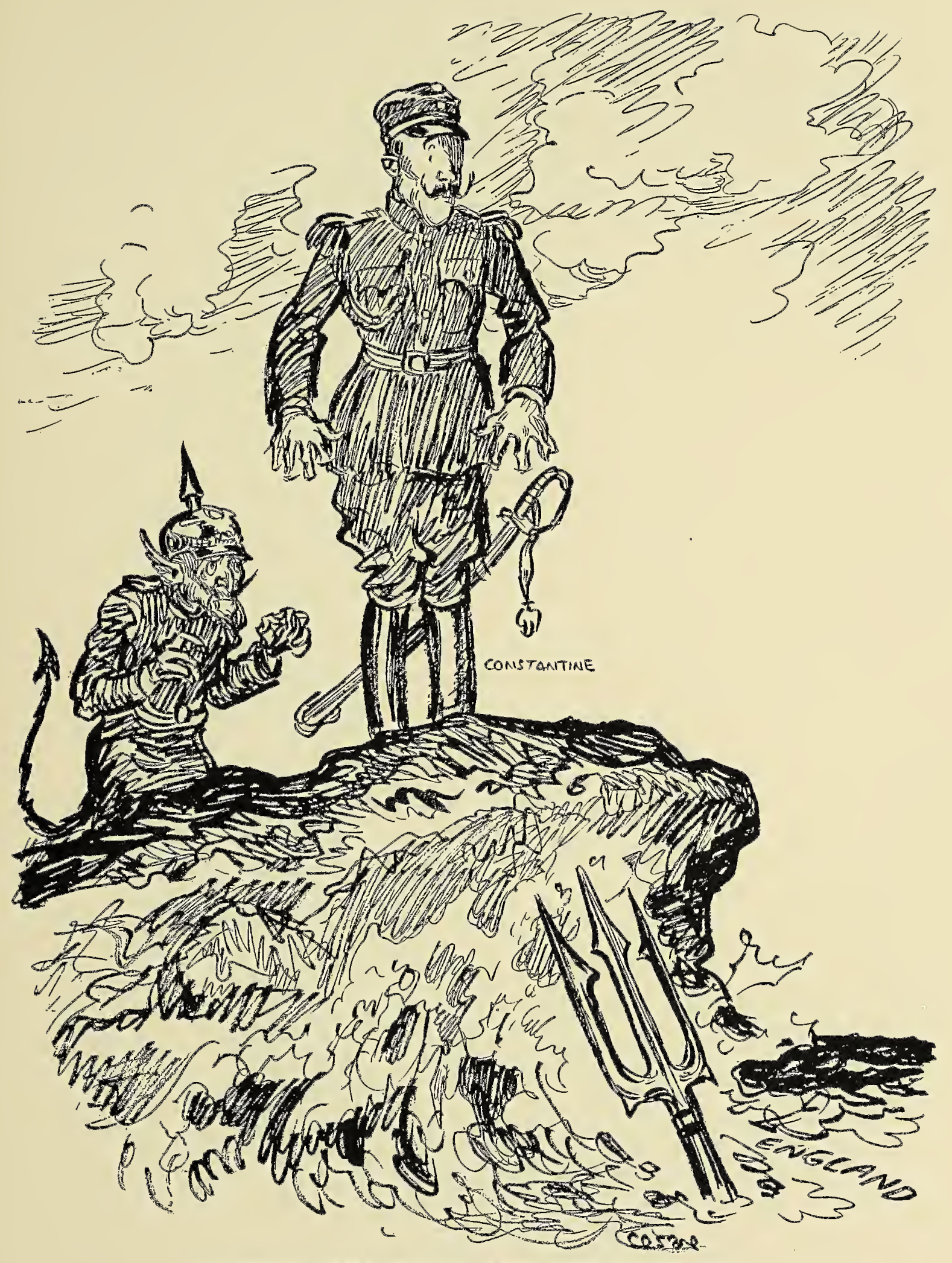

BETWEEN THE DEVIL AND THE DEEP SEA 



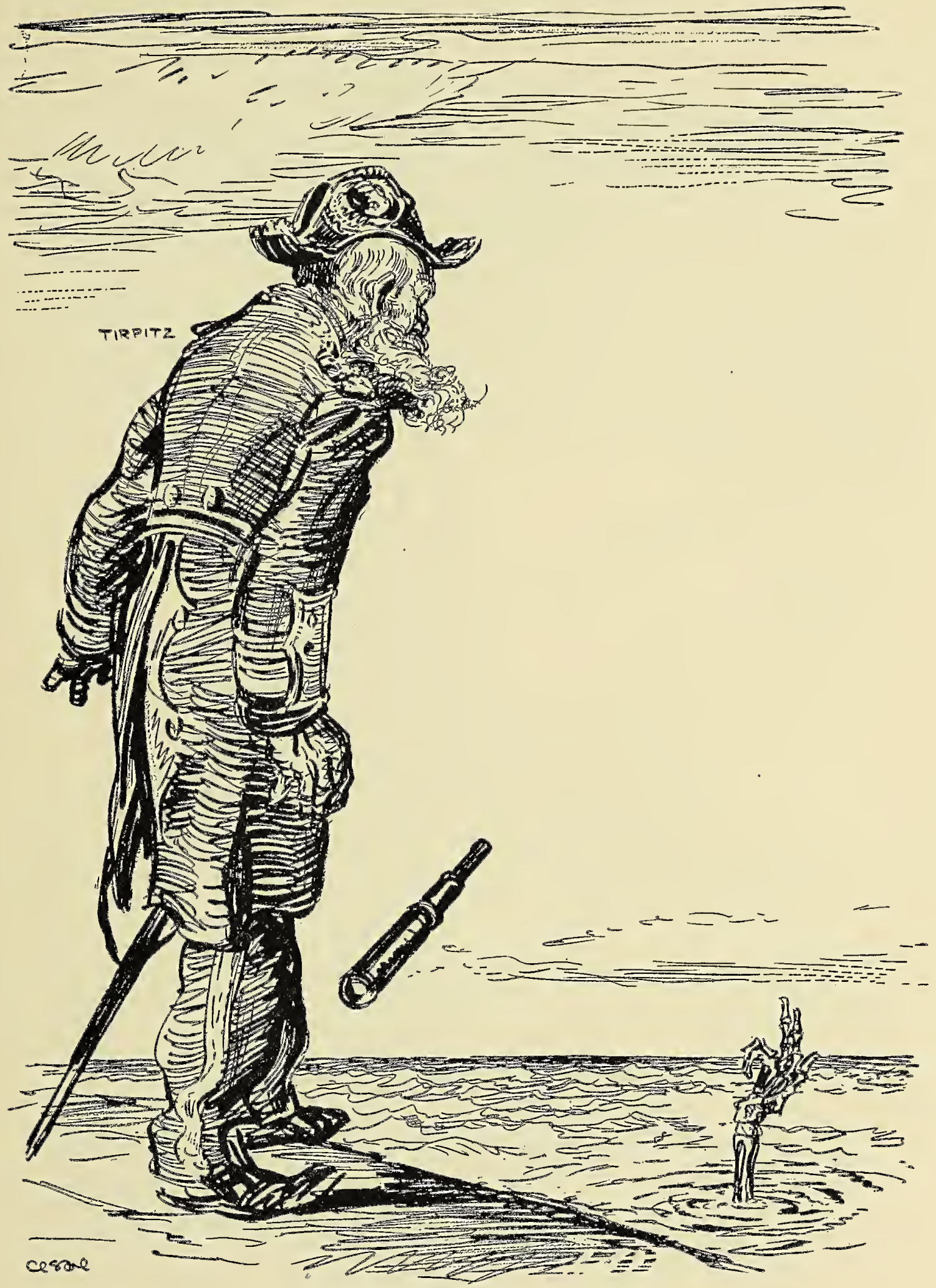

ALWAYS SURE TO REPORT

(German admiralty in doubt as to sinking of ships, as submarines have not yet reported. - Cable dispatch)

[ 1113$]$ 



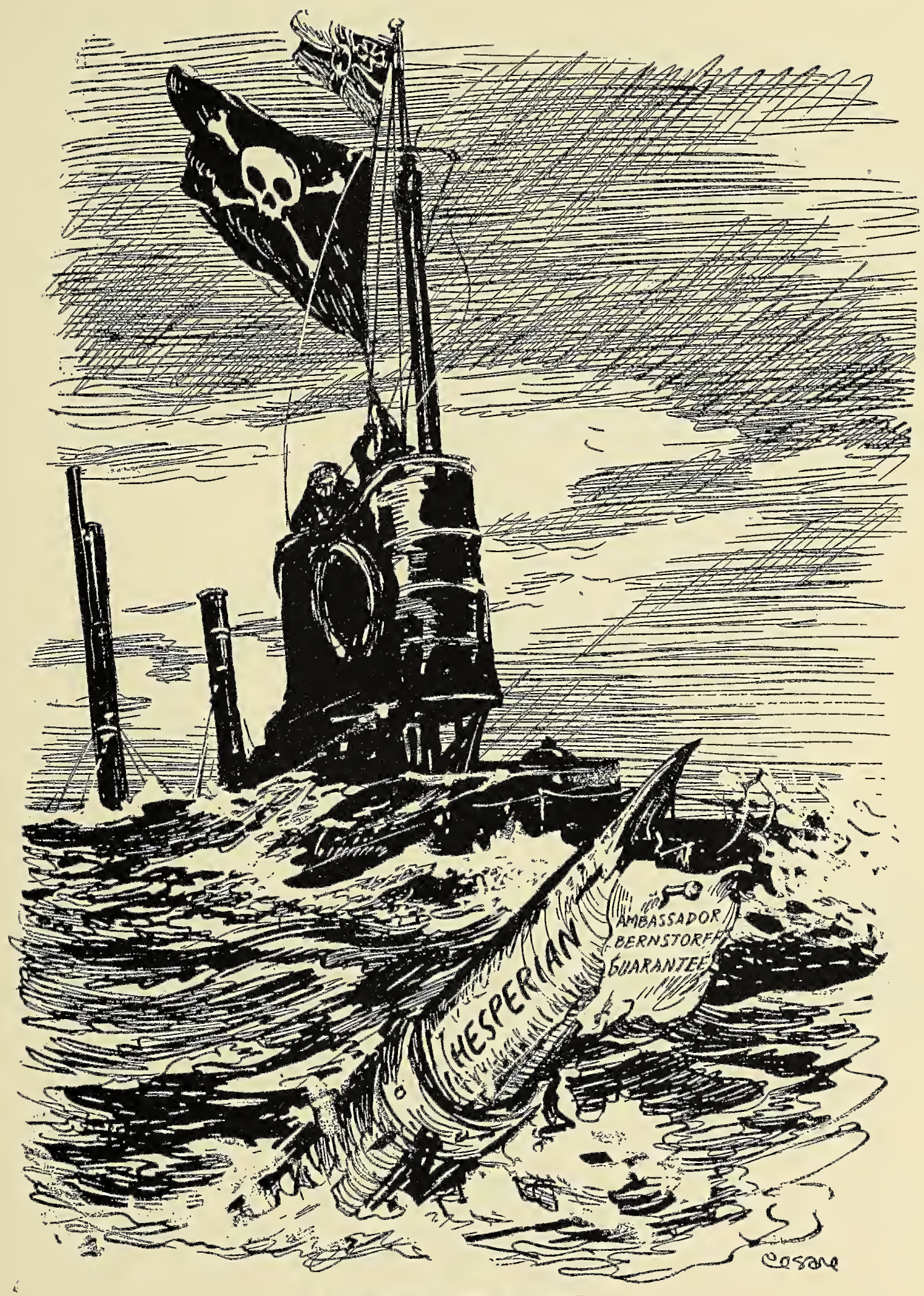

HOISTING IT AGAIN

[ 1115$]$ 



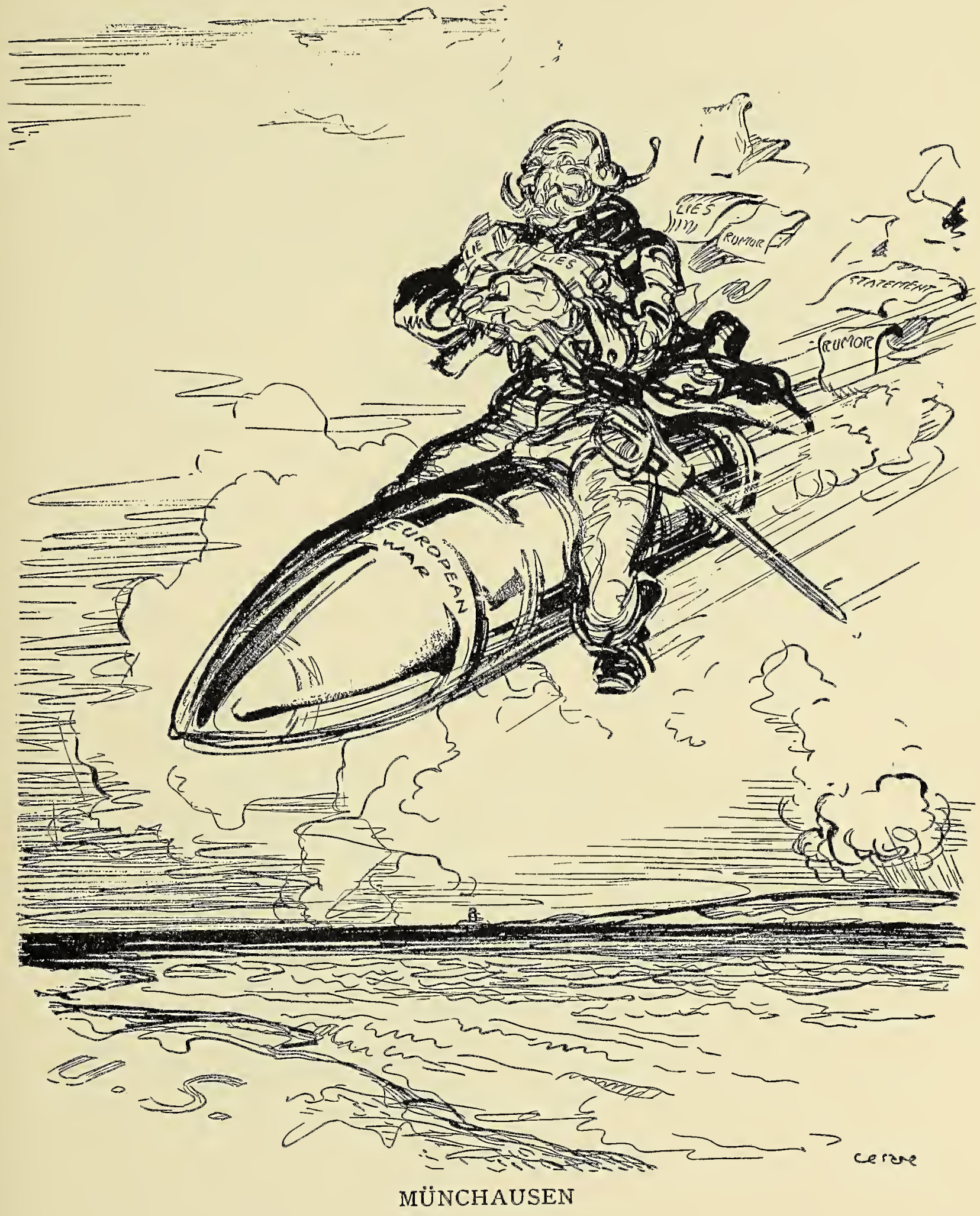

$[117]$ 


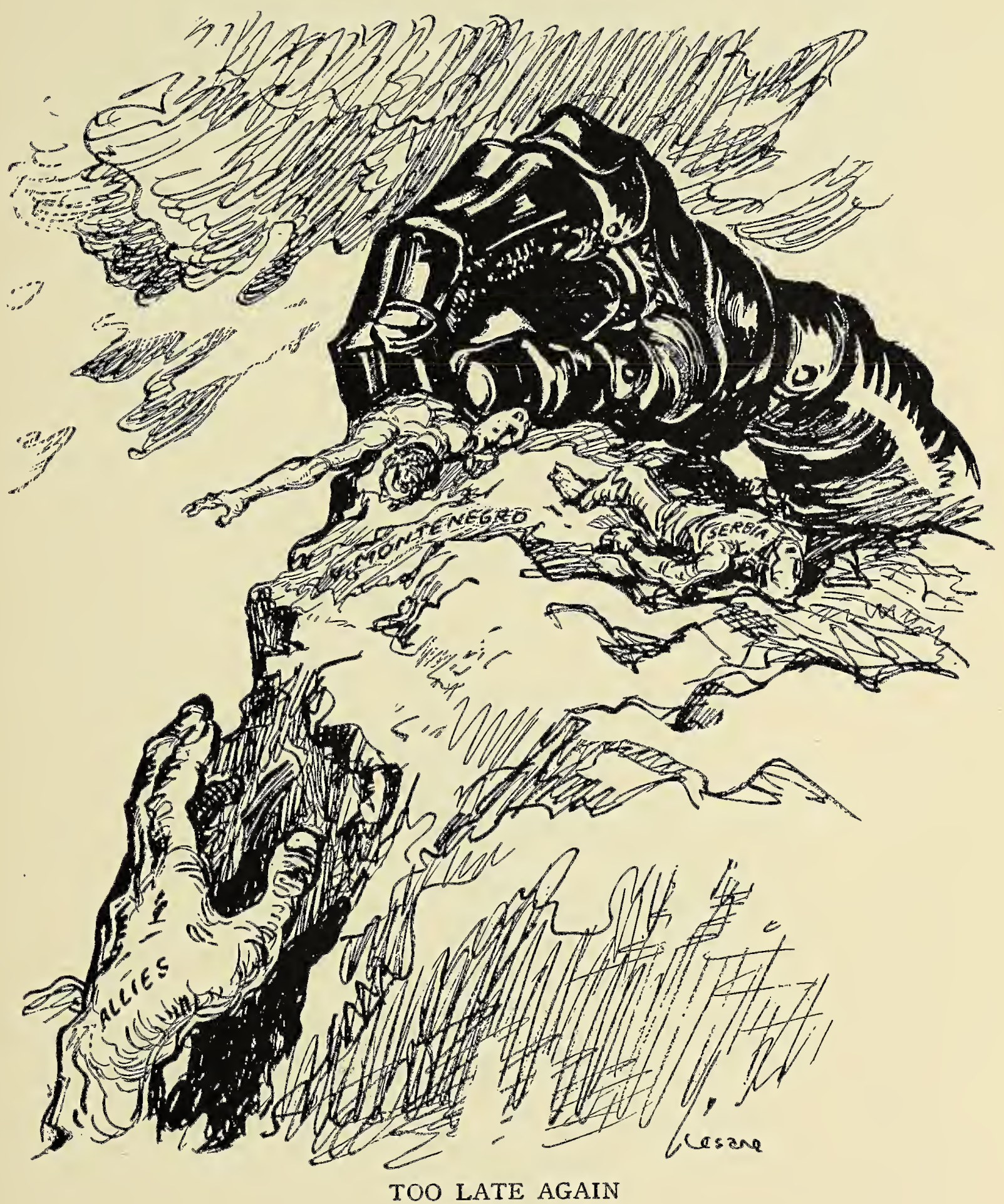

[119] 



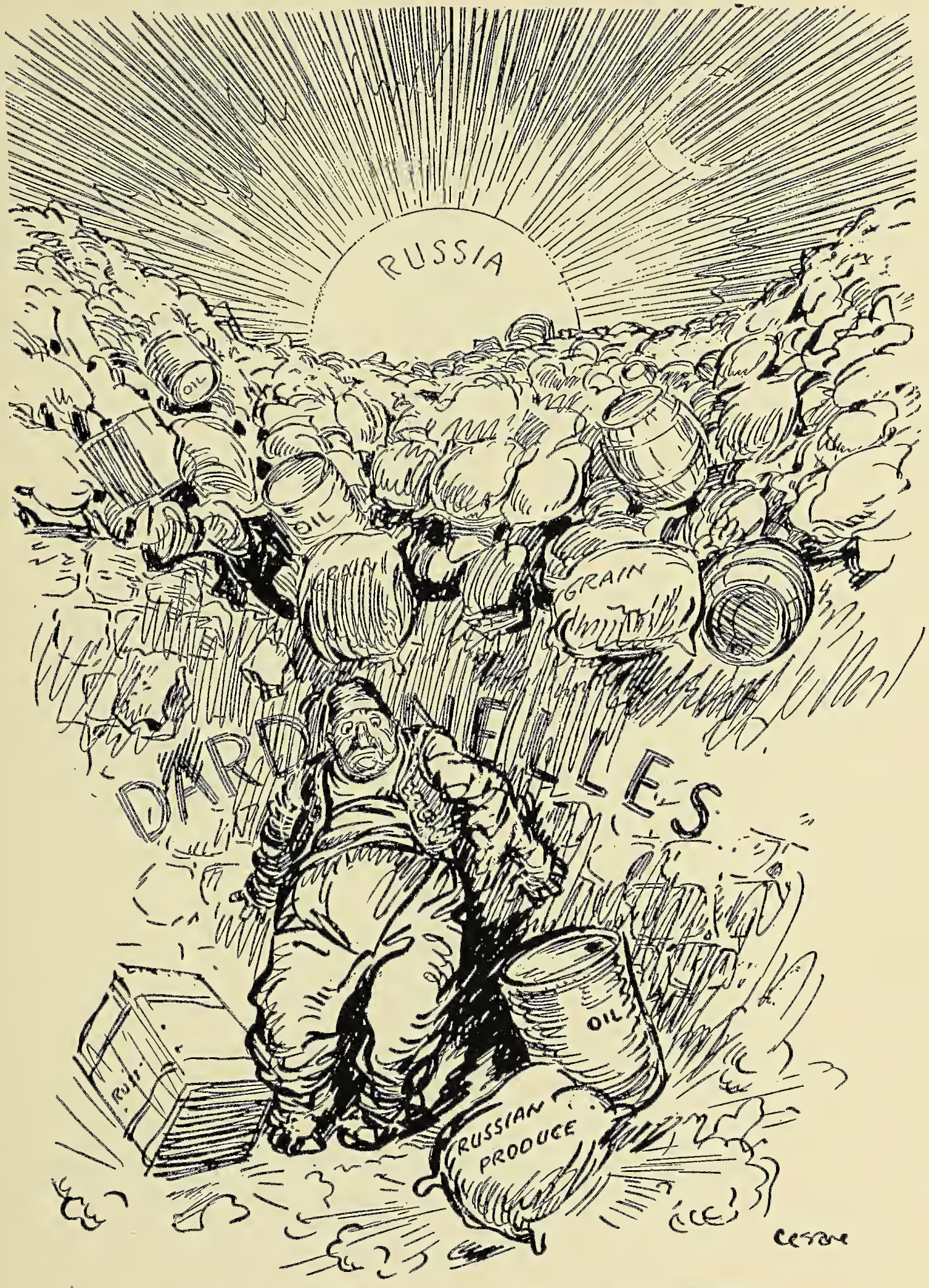

FORCING THE DARDANELLES - A NIGHTMARE 
• 


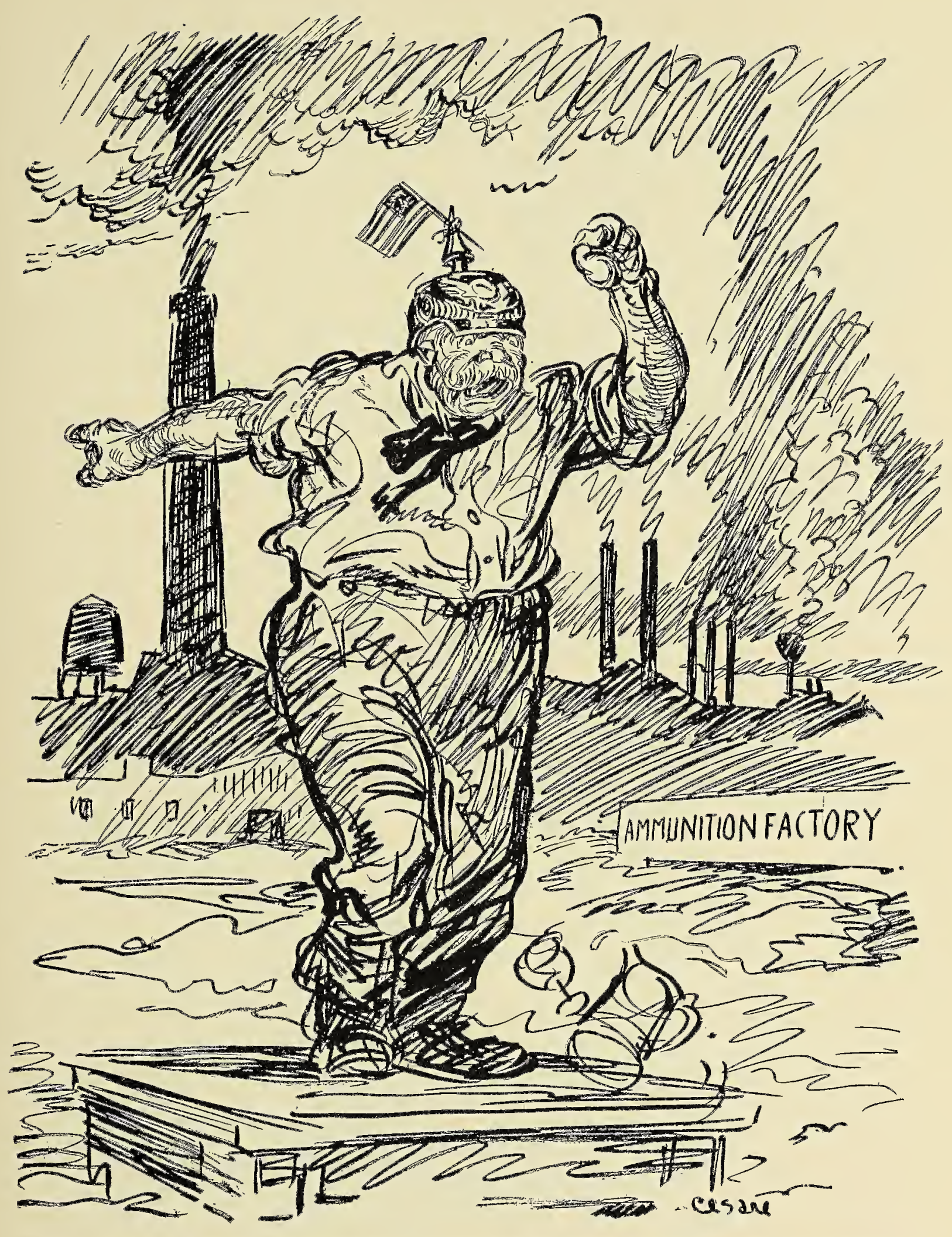

"CLOSE UP THESE FACTORIES! SHERMAN WAS RIGHT. BE NEUTRAL!" 



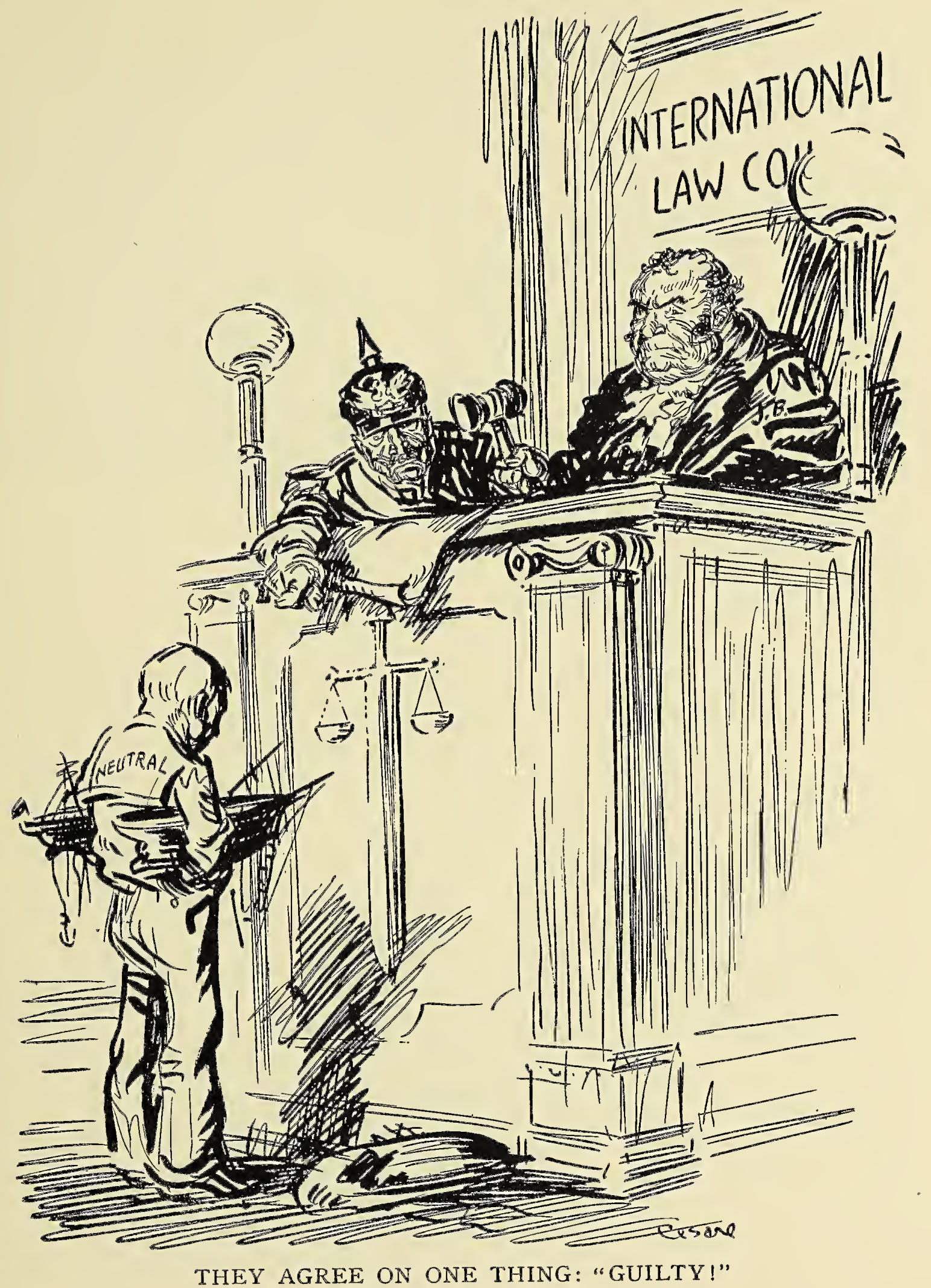





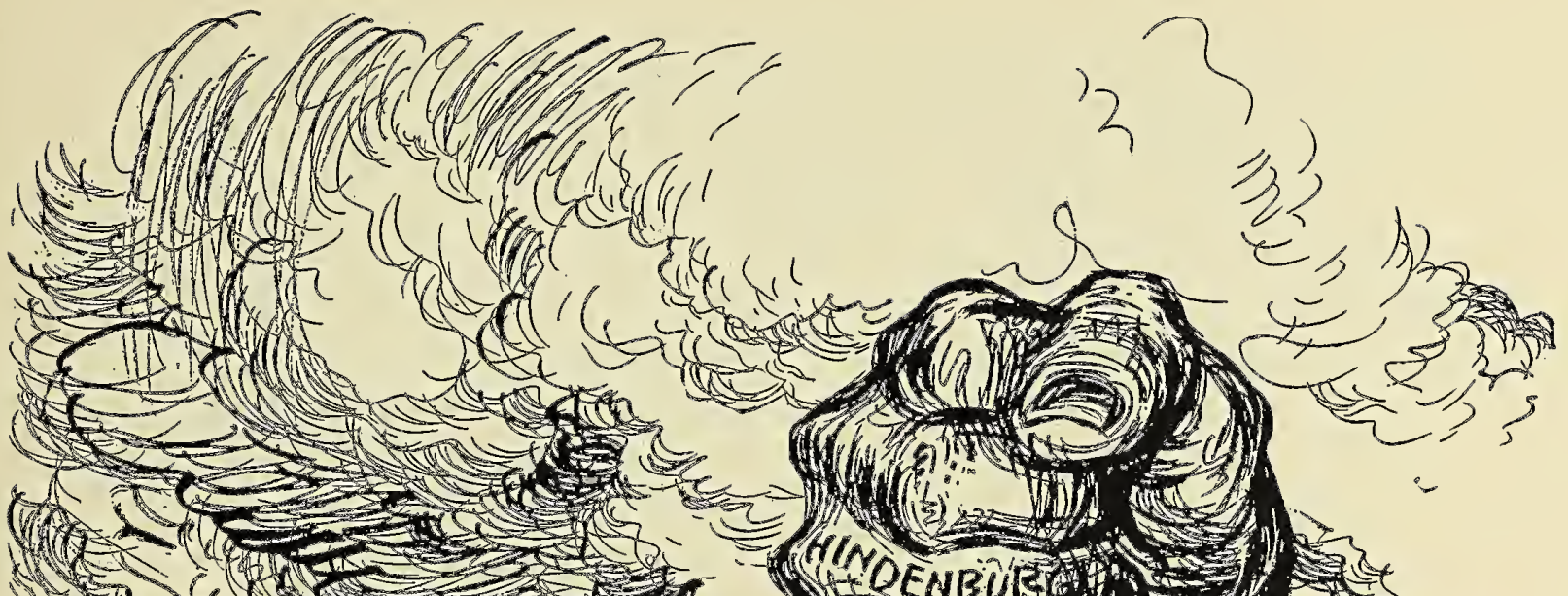

N.

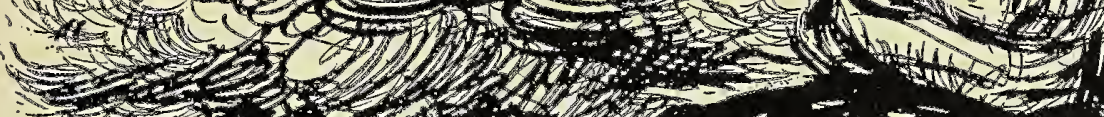
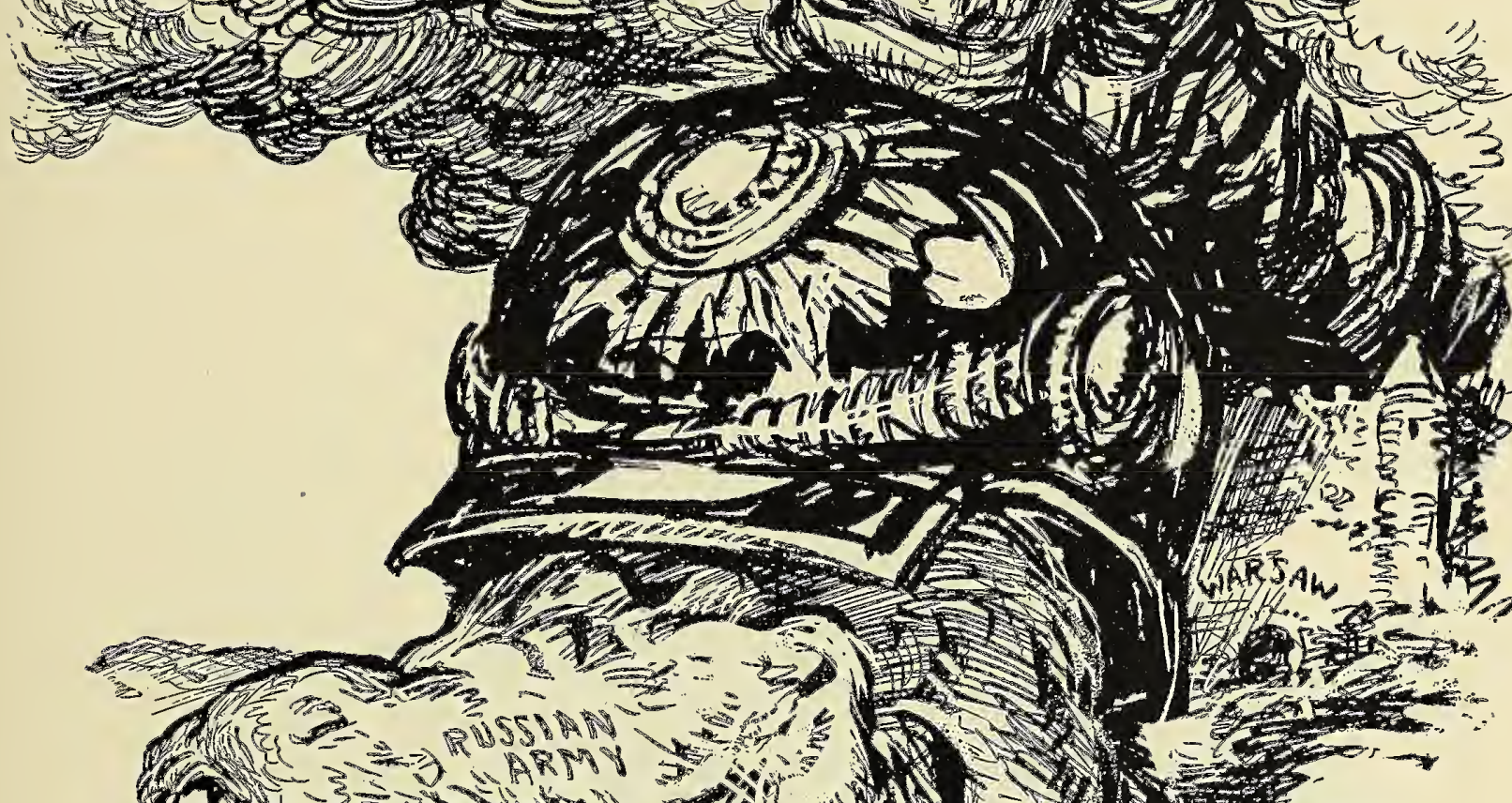

( 1 (1) $-3=3$ -

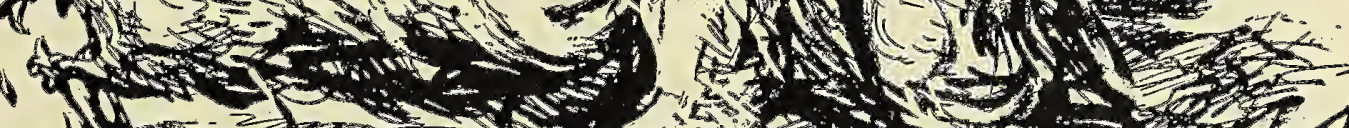
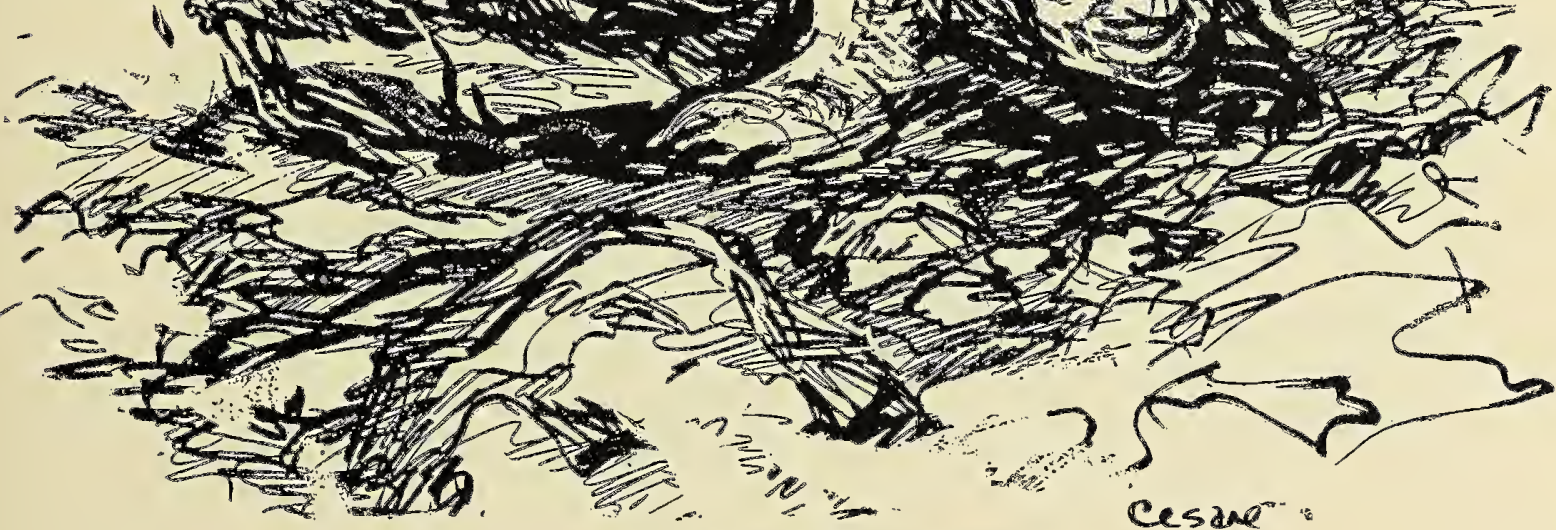

WILL HE GET HIM?

(The Russian army escapes Hindenburg, winter, 1915) 



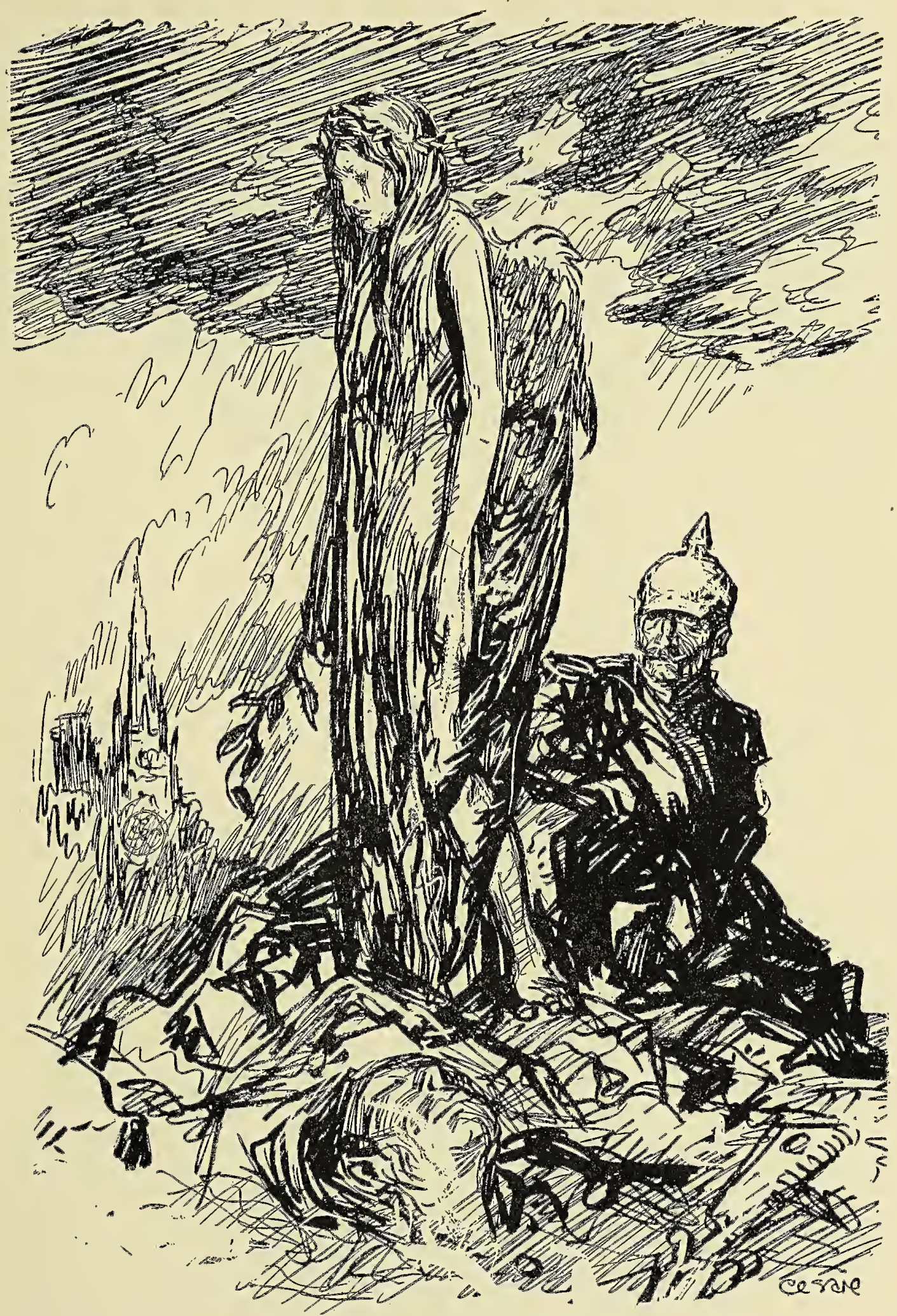

EMPEROR WILLIAM INTRODUCES PEACE

(A German peace rumor, September 3, 1915) 



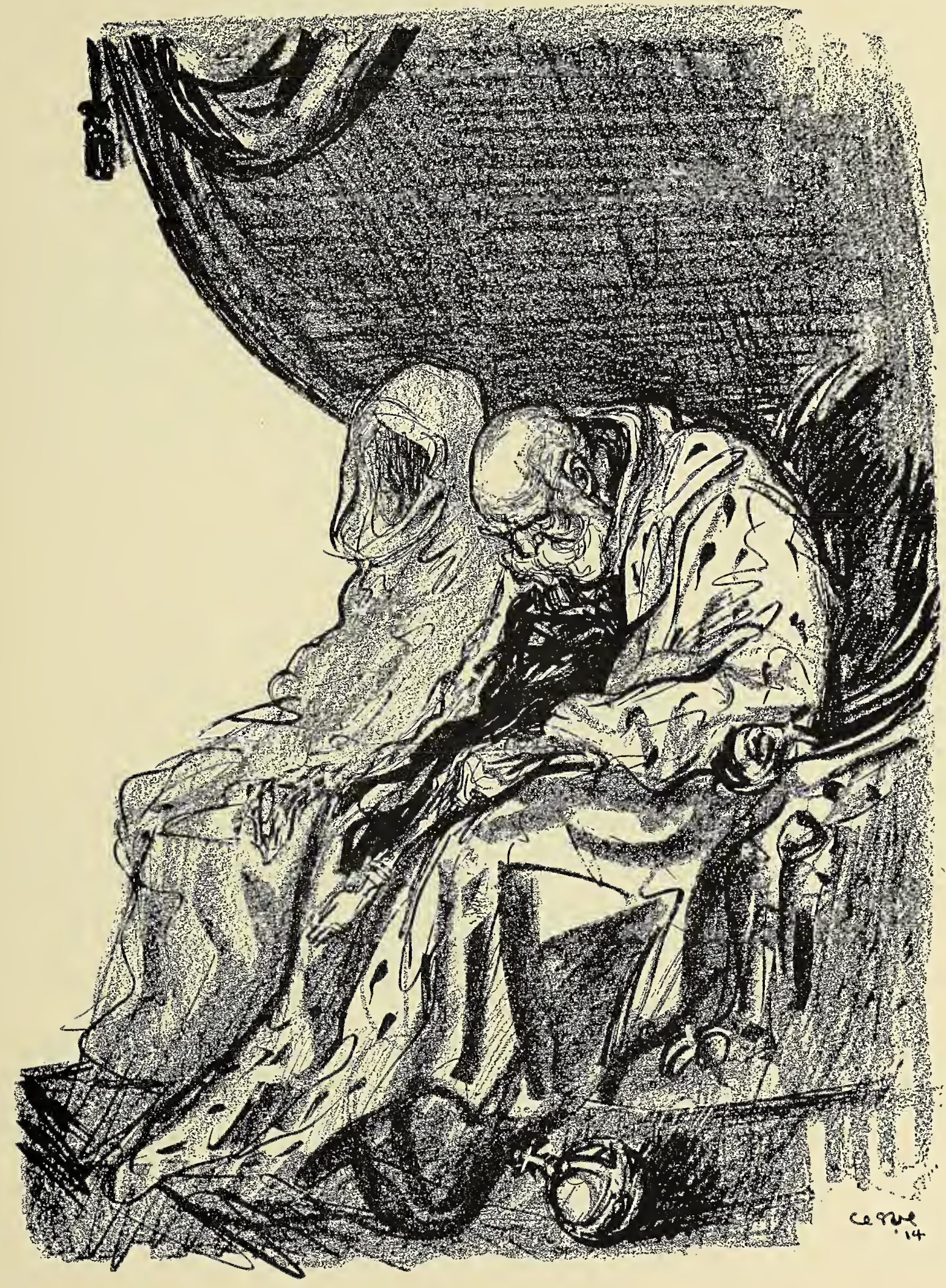

THE DUAL THRONE 



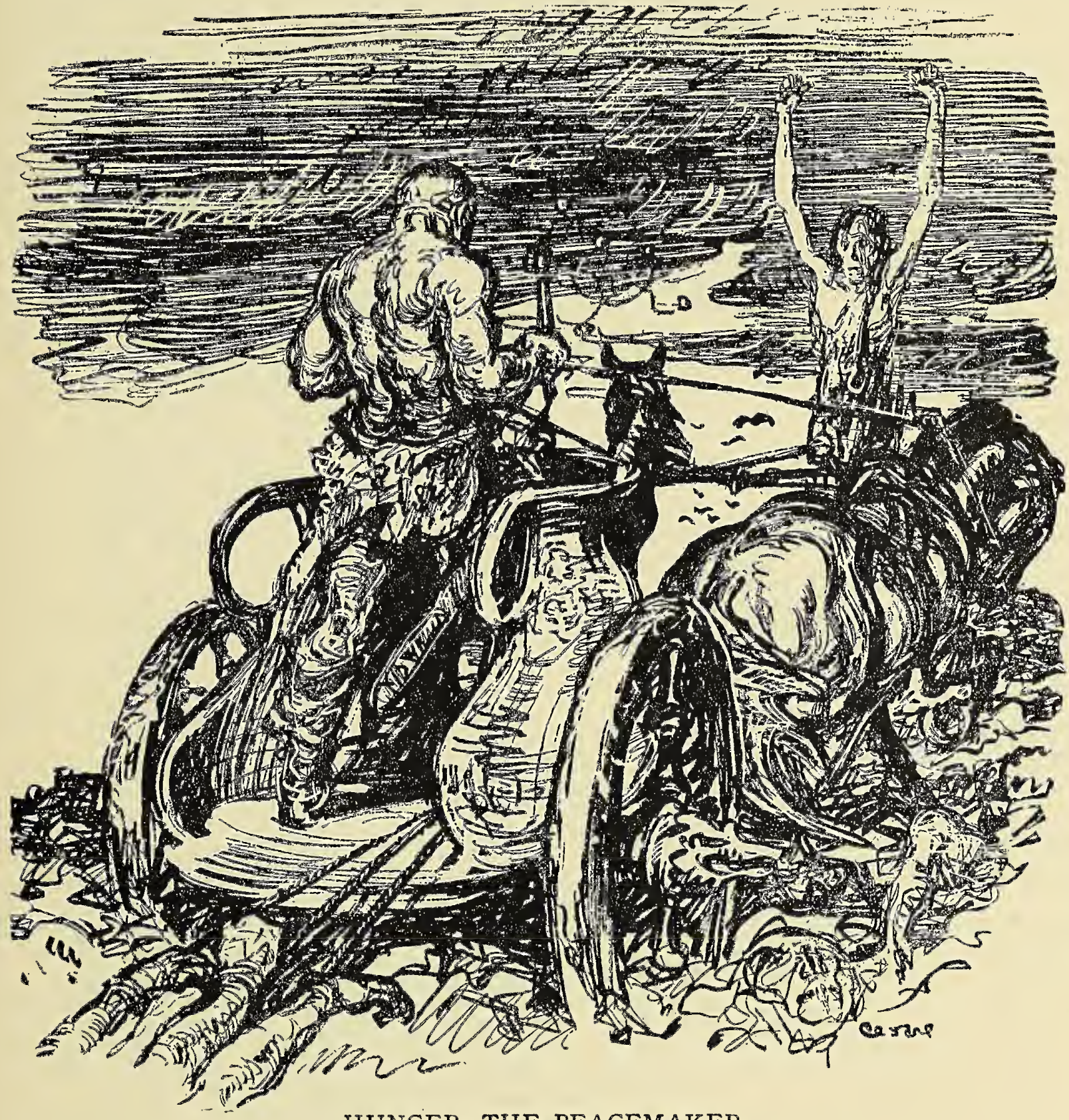

HUNGER, THE PEACEMAKER

[133] 



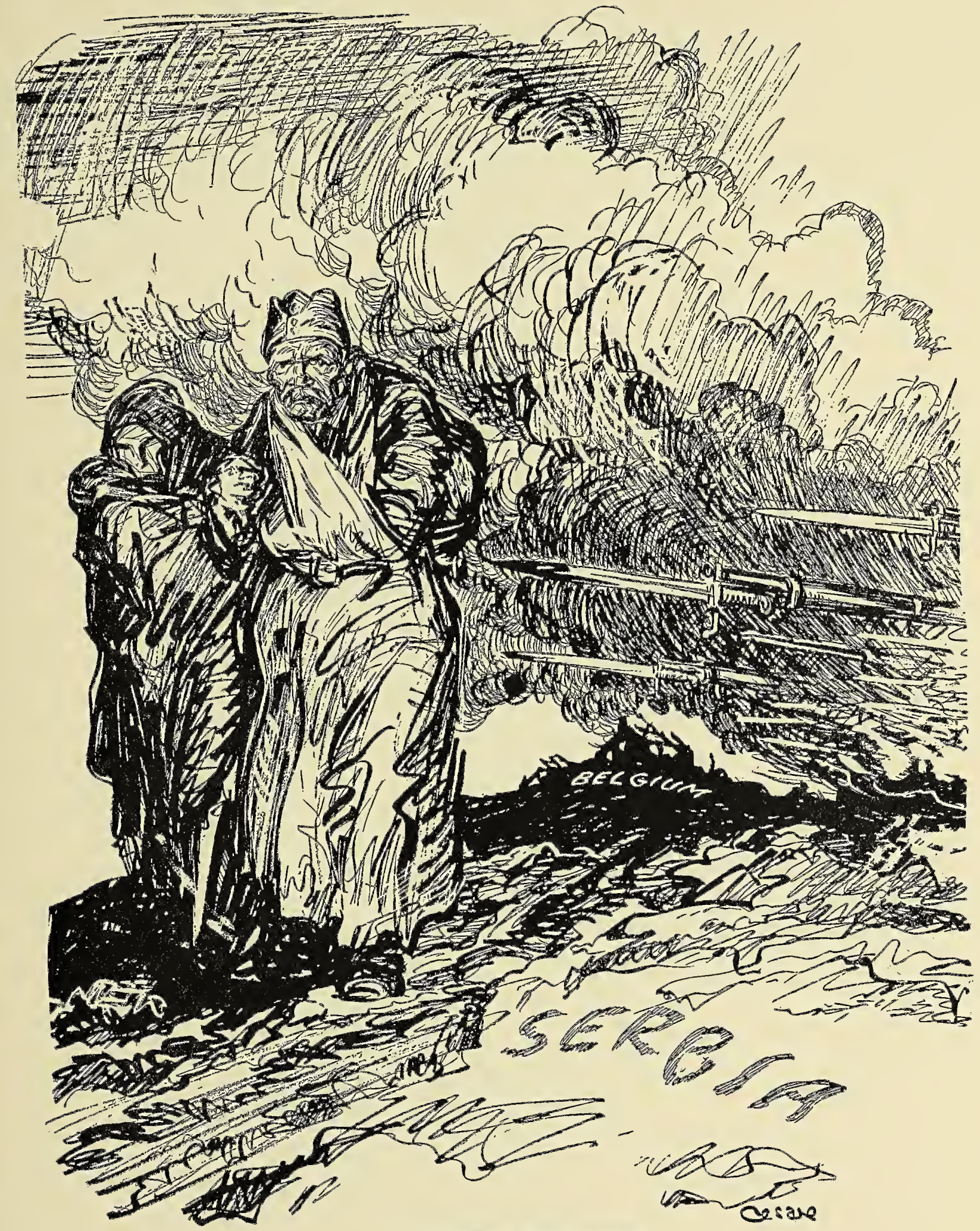

ANOTHER EVICTION

(November, 1915) 



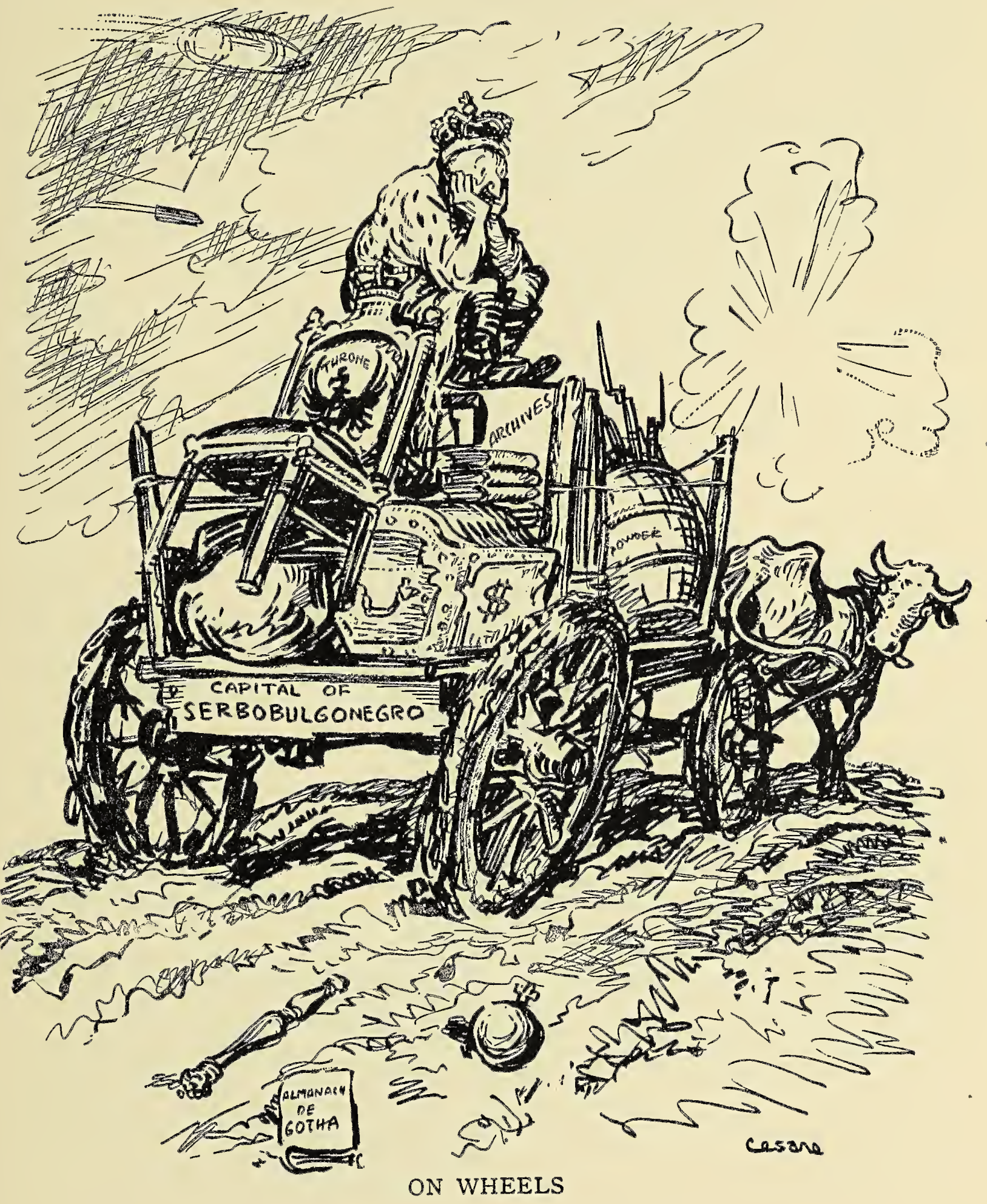

[137] 



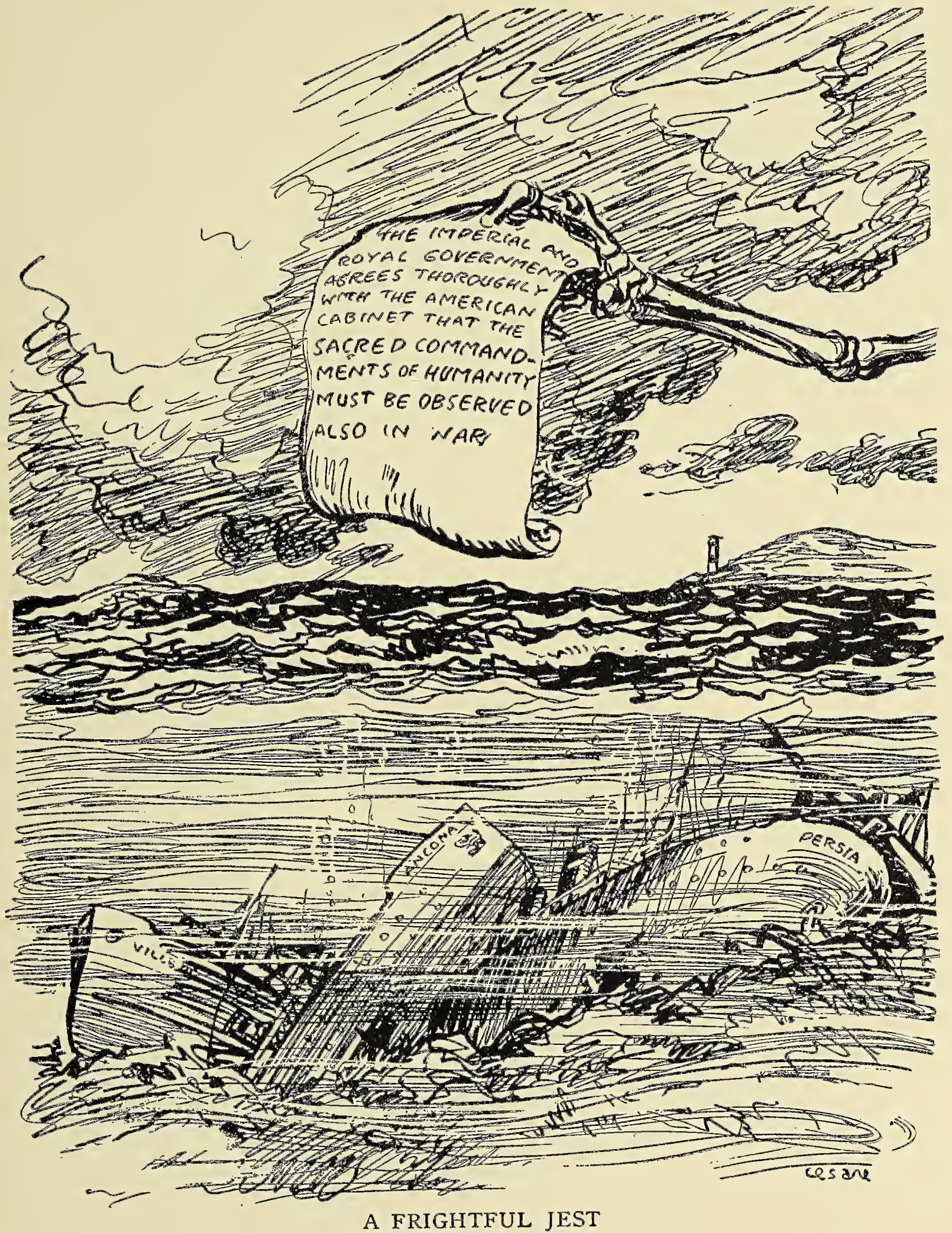

[139] 



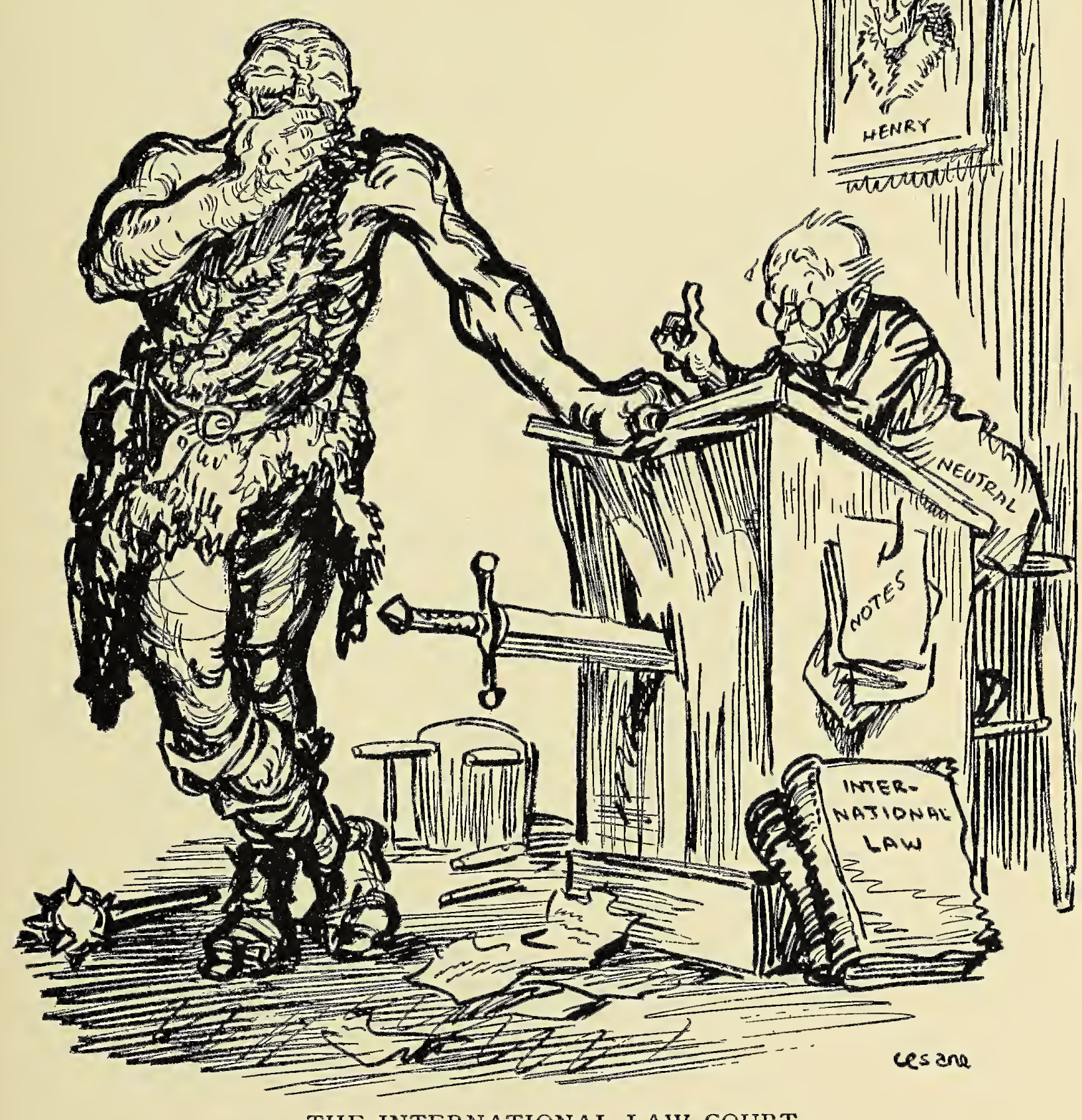

THE INTERNATIONAL LAW COURT

Belligerent: "Don't make me laugh, - it 's inappropriate" 



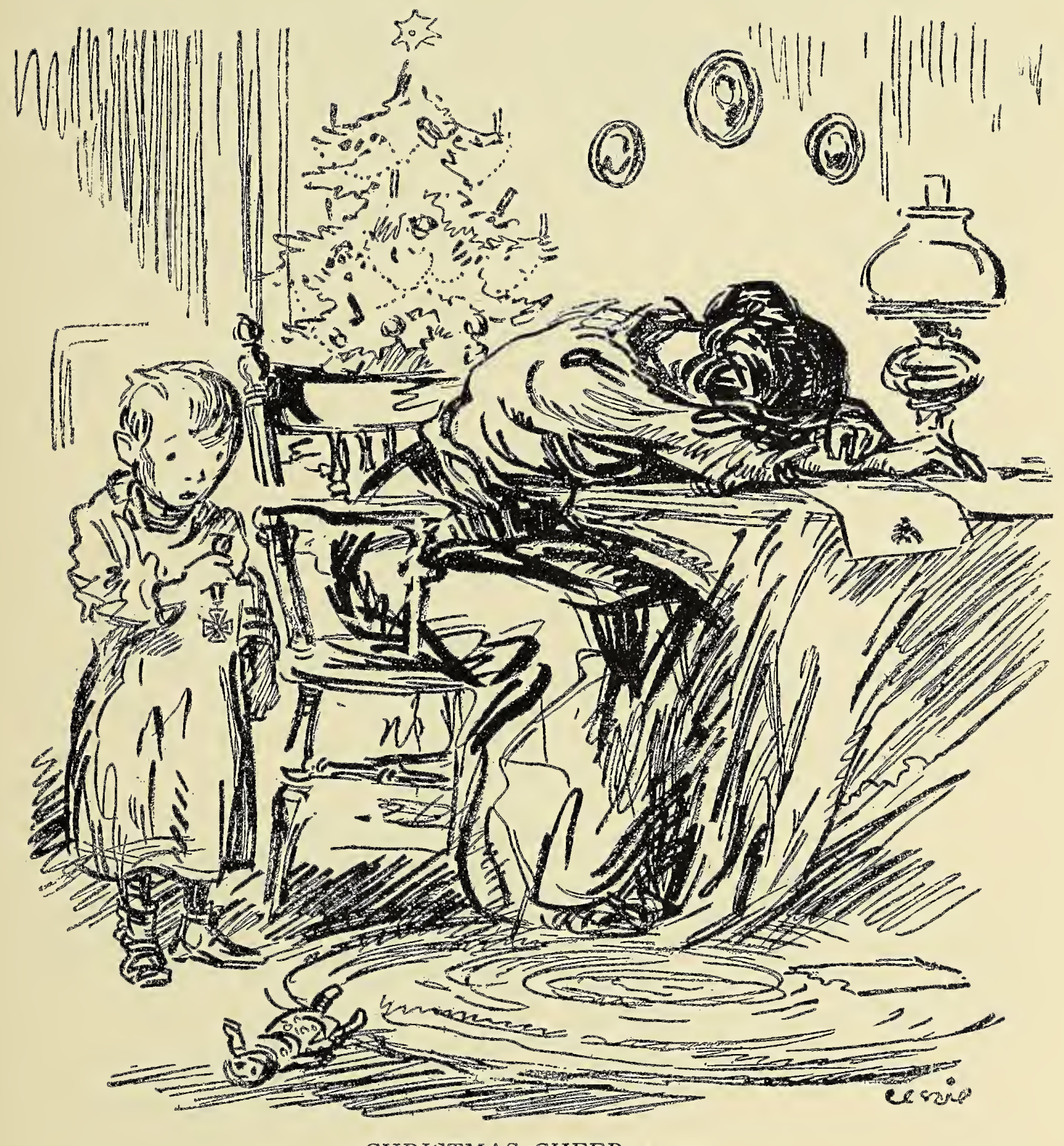

CHRISTMAS CHEER, I9I 5 


$$
\text { • }
$$




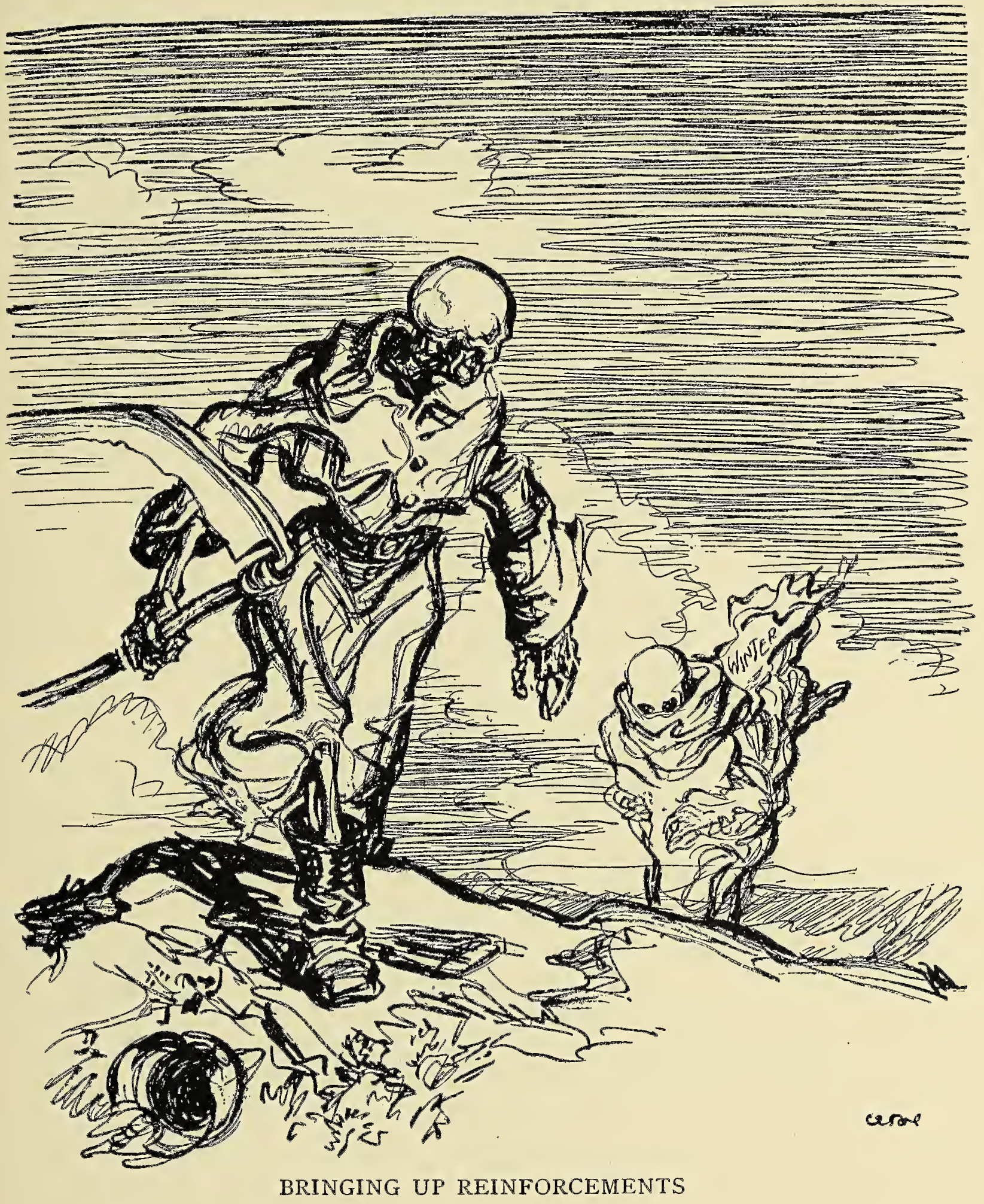

$[145]$ 



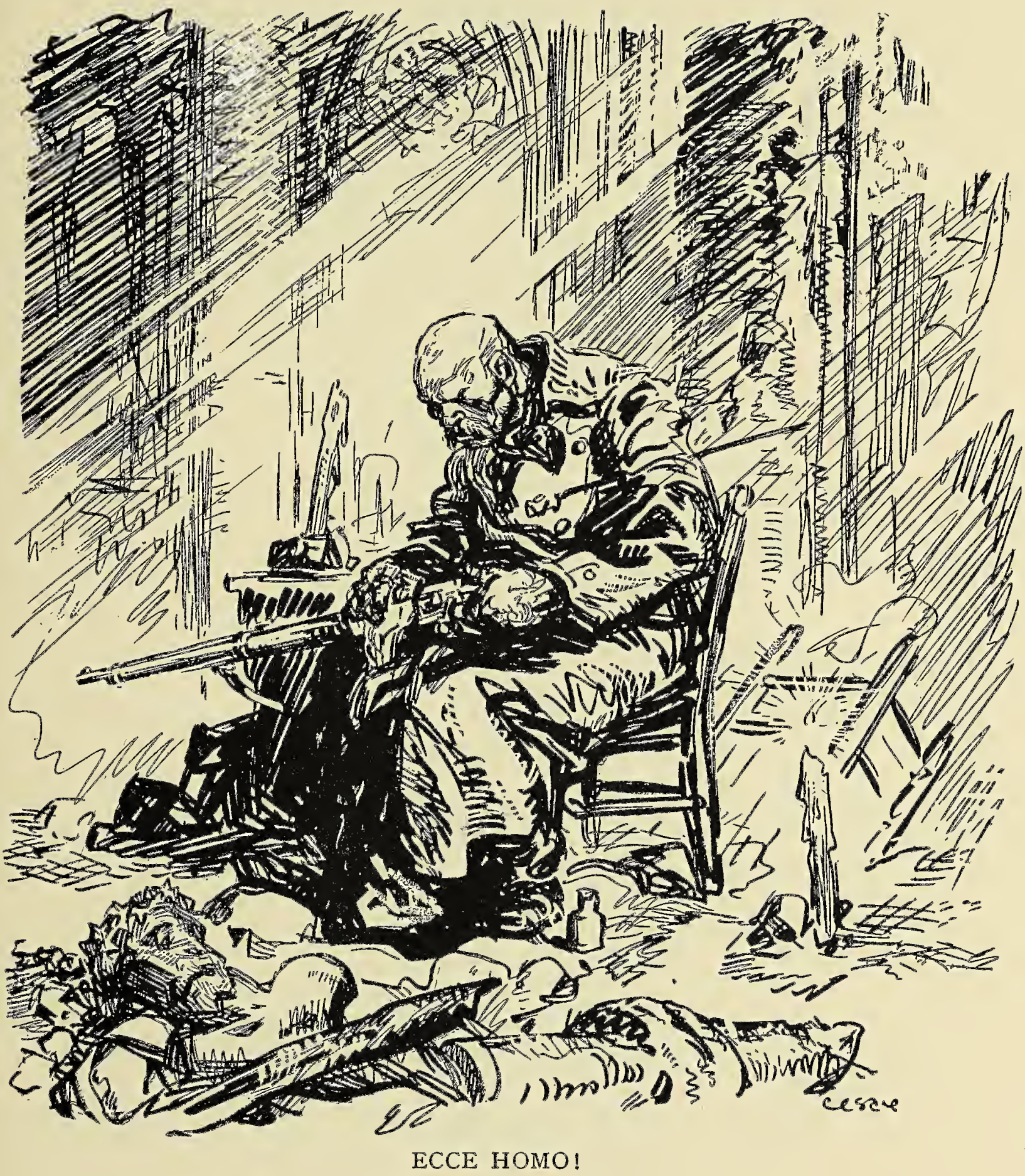

(January 9, 1916) 



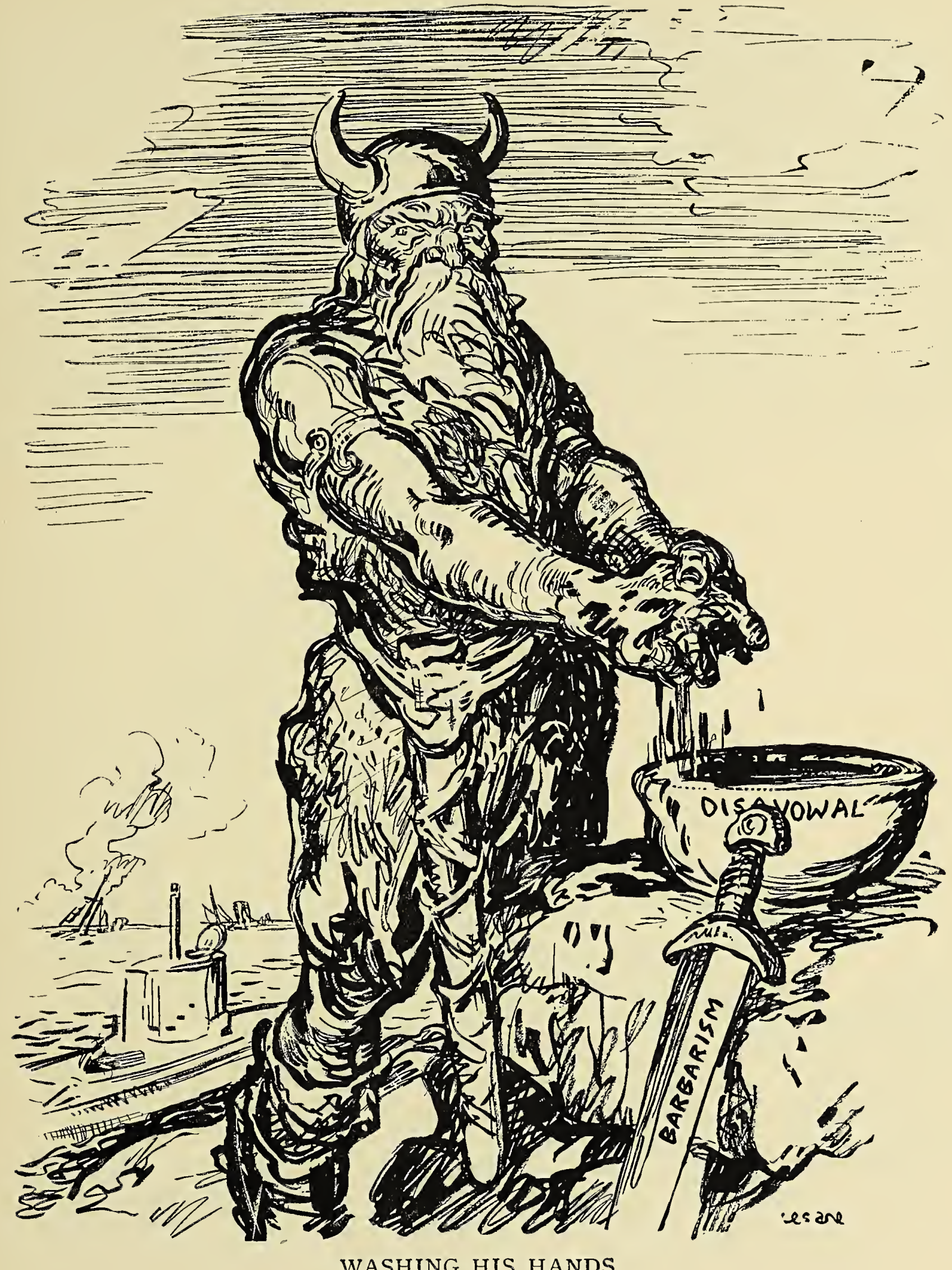

WASHING HIS HANDS

(January 4, 1916) 



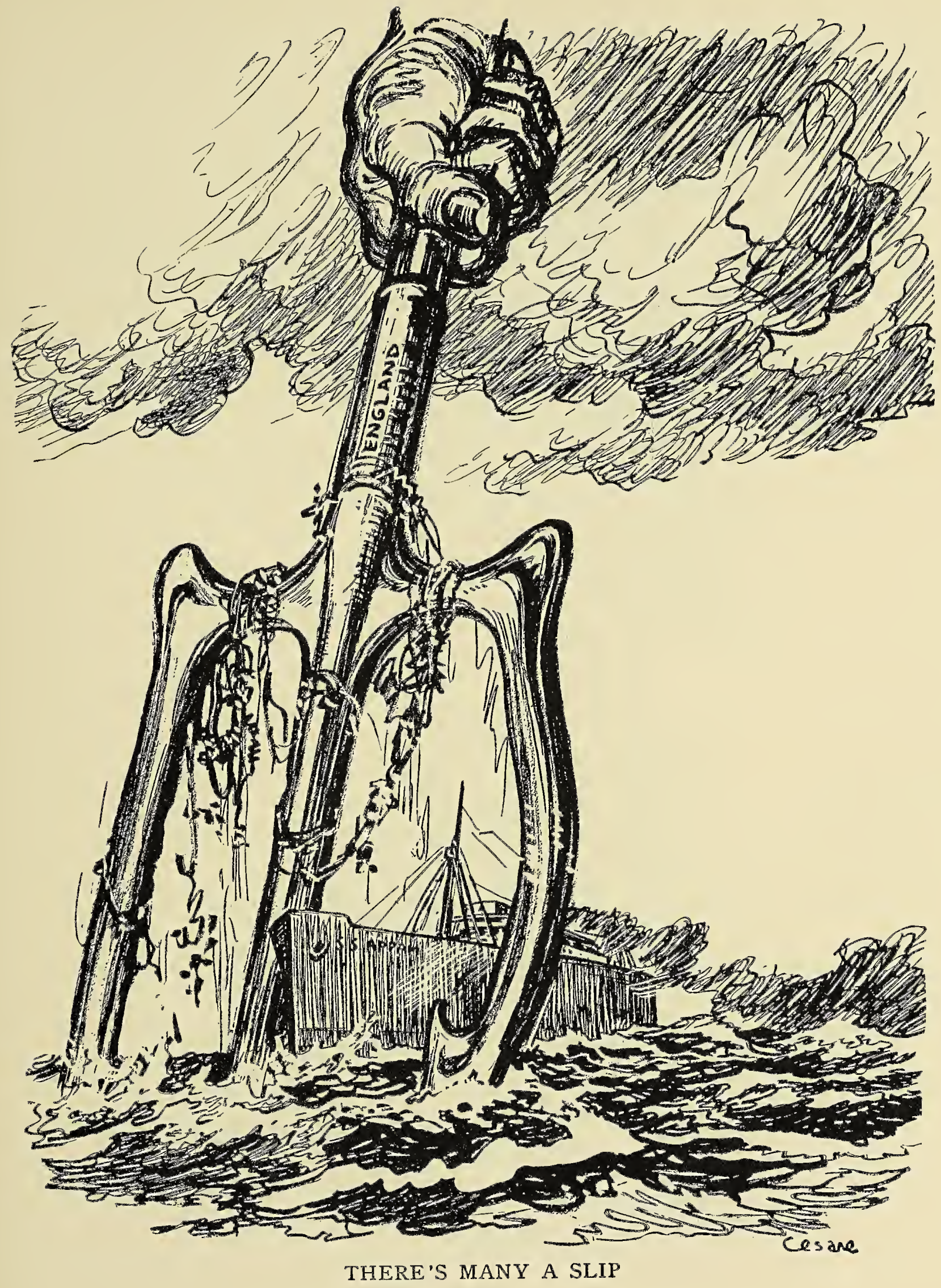

[1 151$]$ 



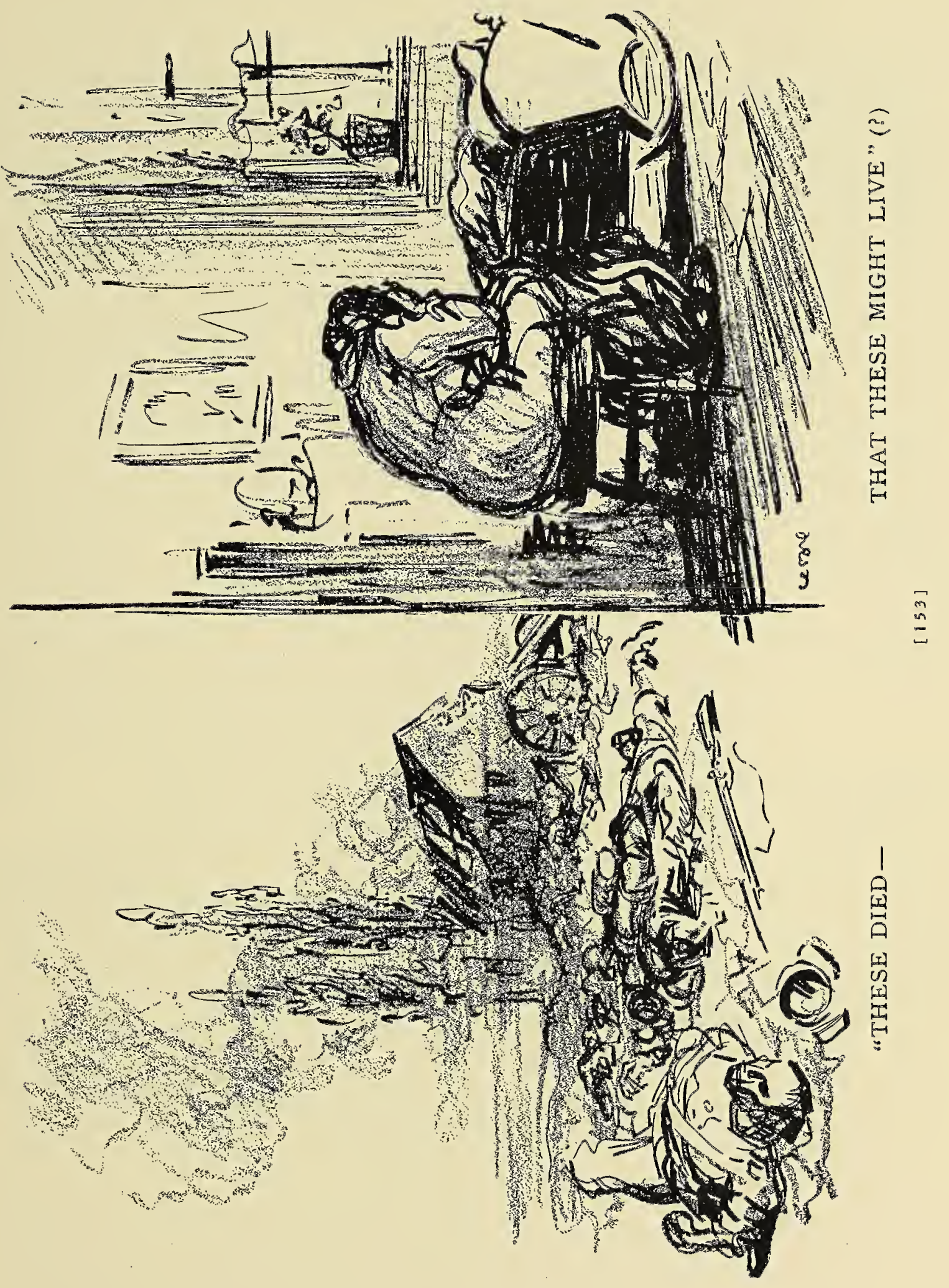





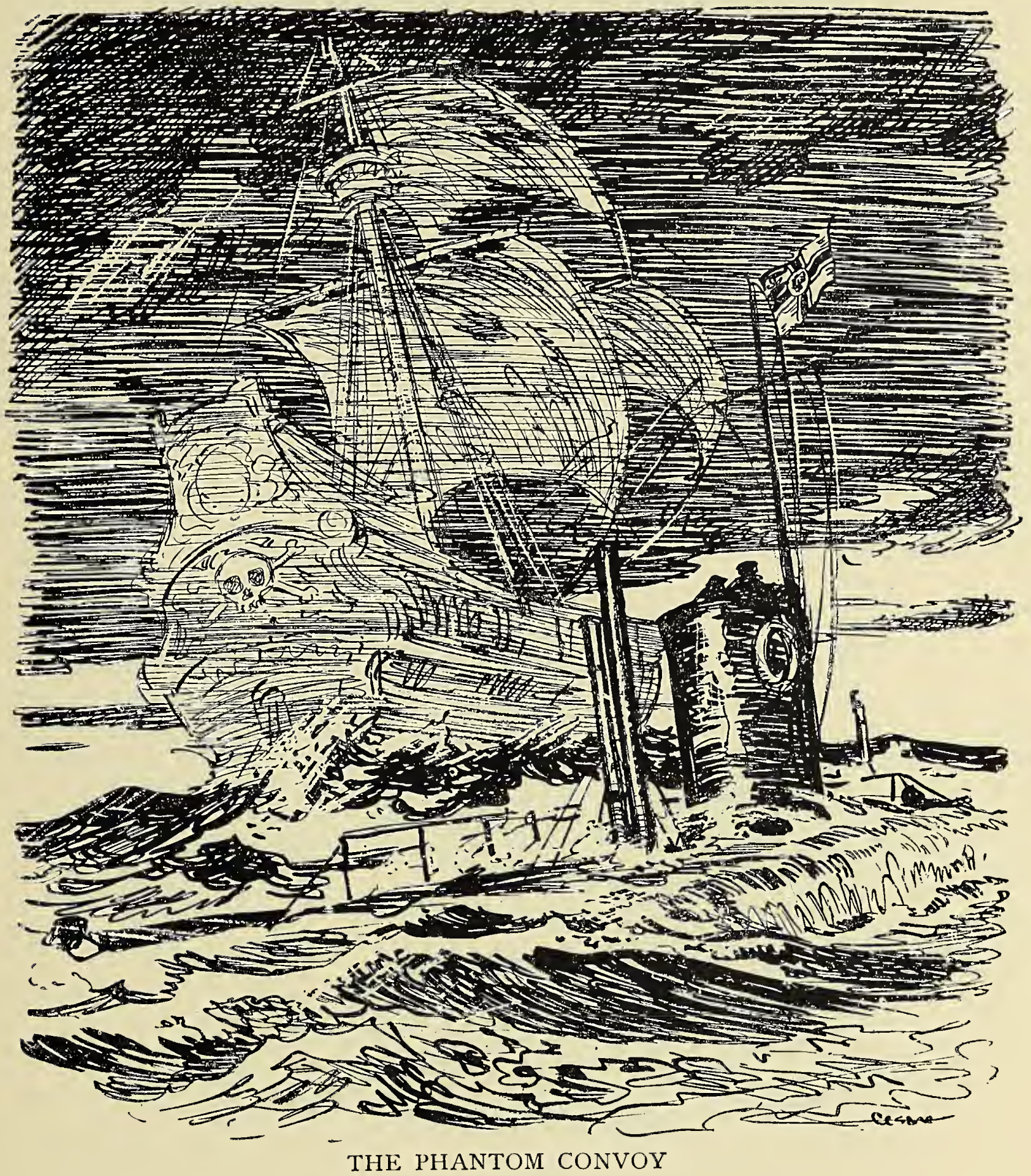

[155] 



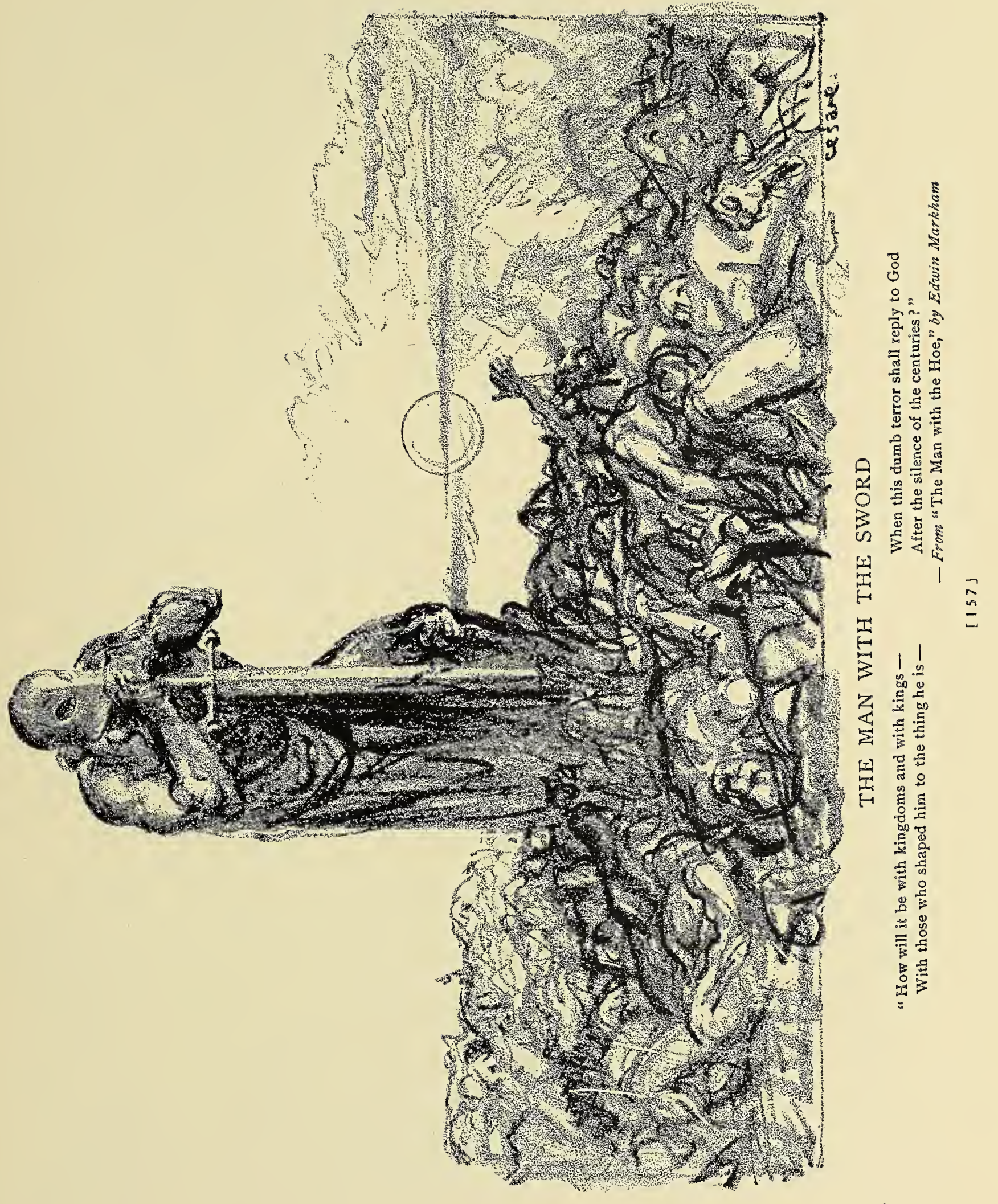





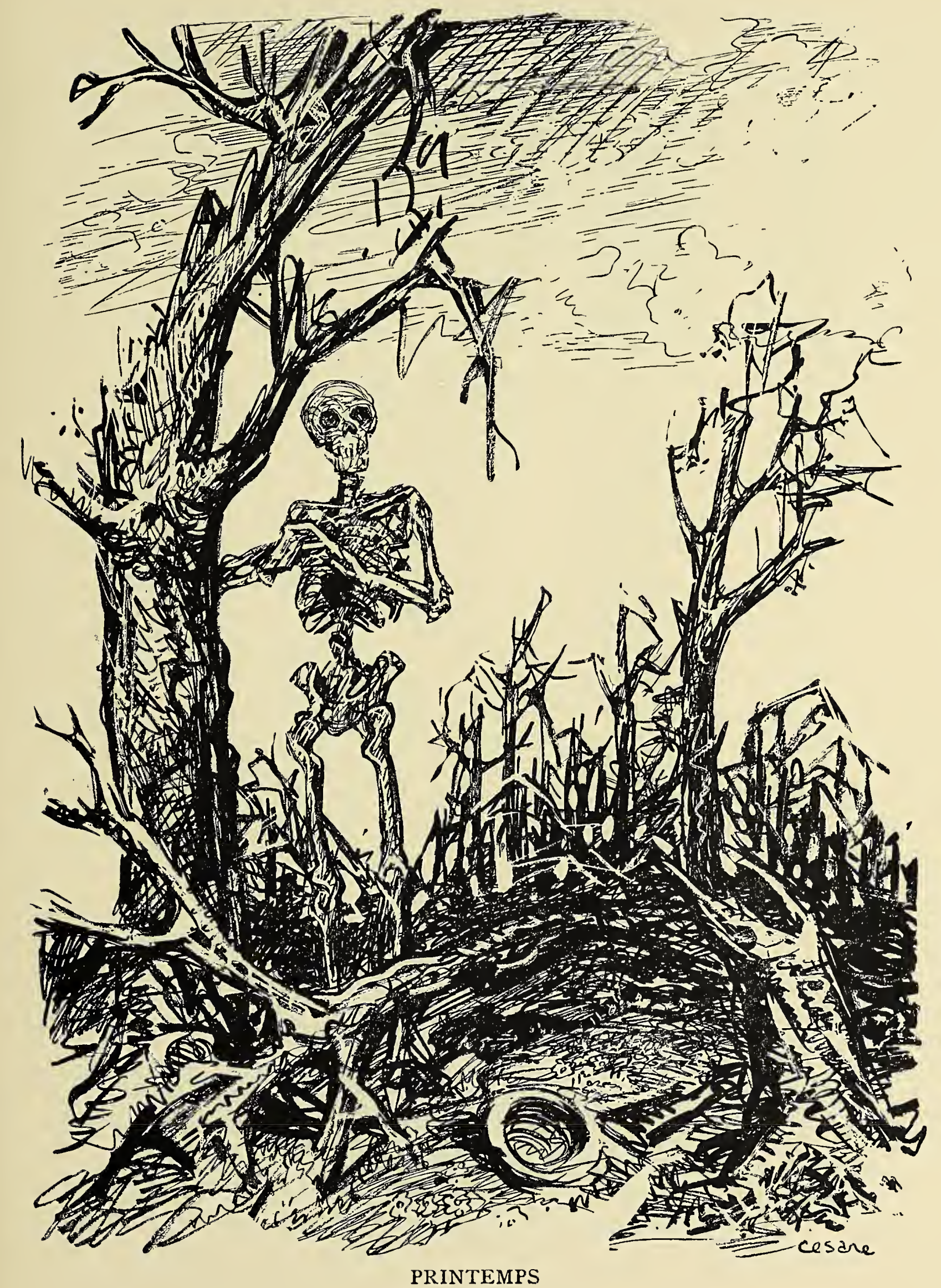

[1 59 ] 


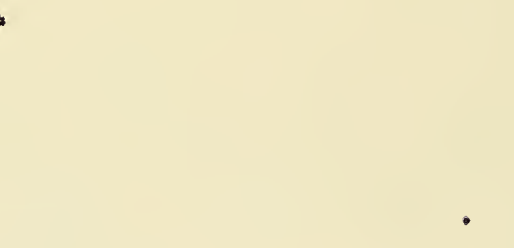



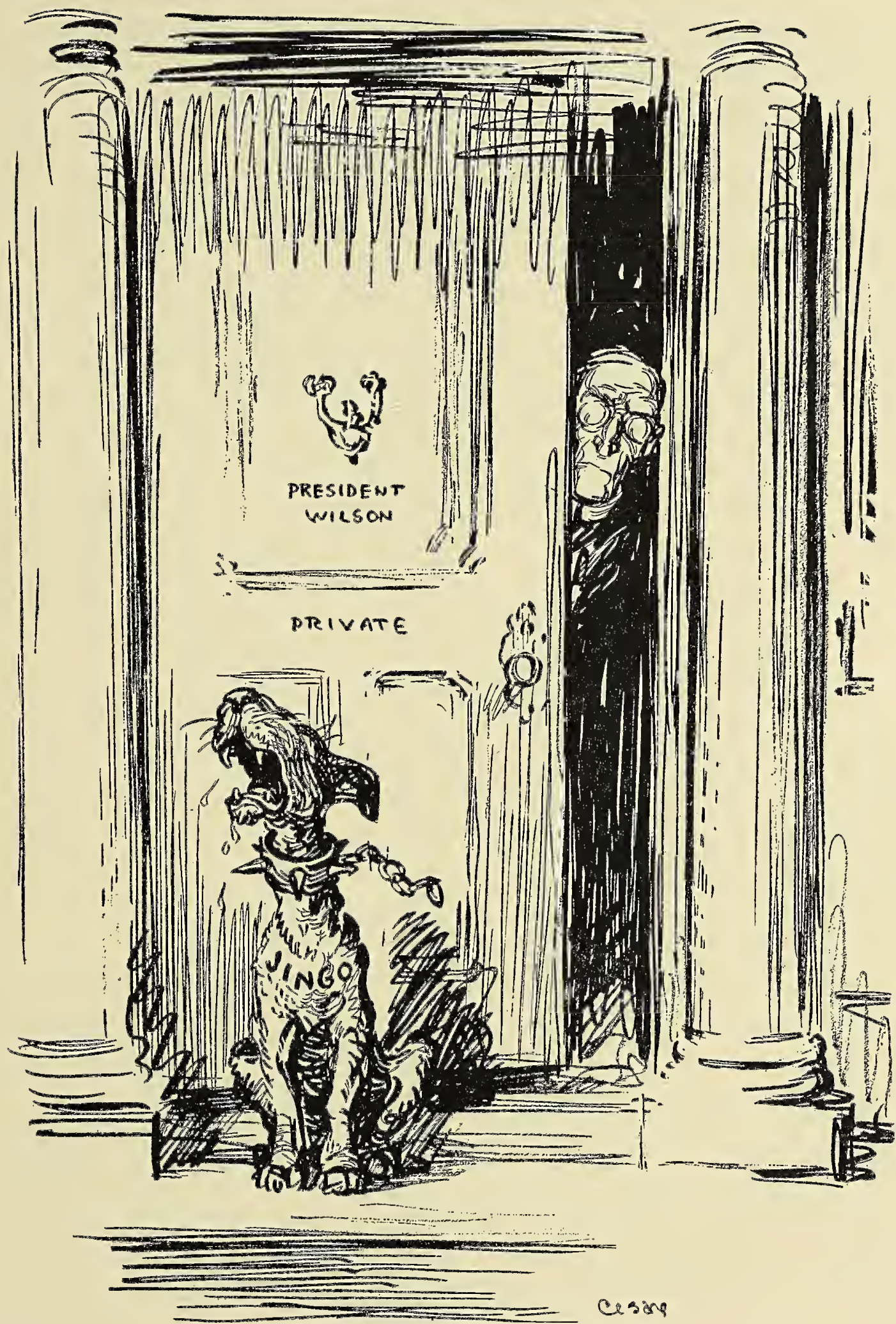

THE AMERICAN WAR-DOG

(The American-German crisis, January-March, 1916)

[161] 



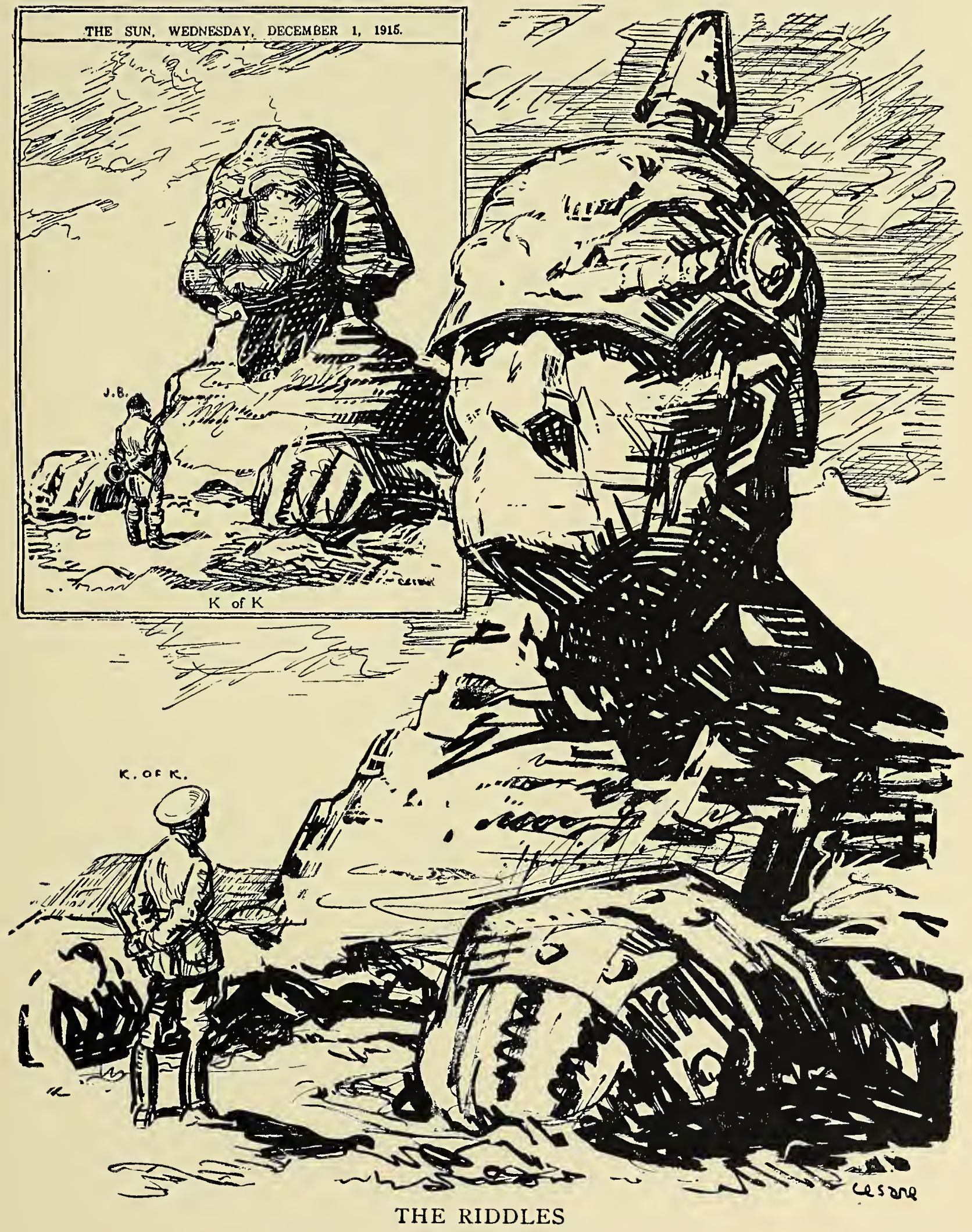

[ 1663 ] 


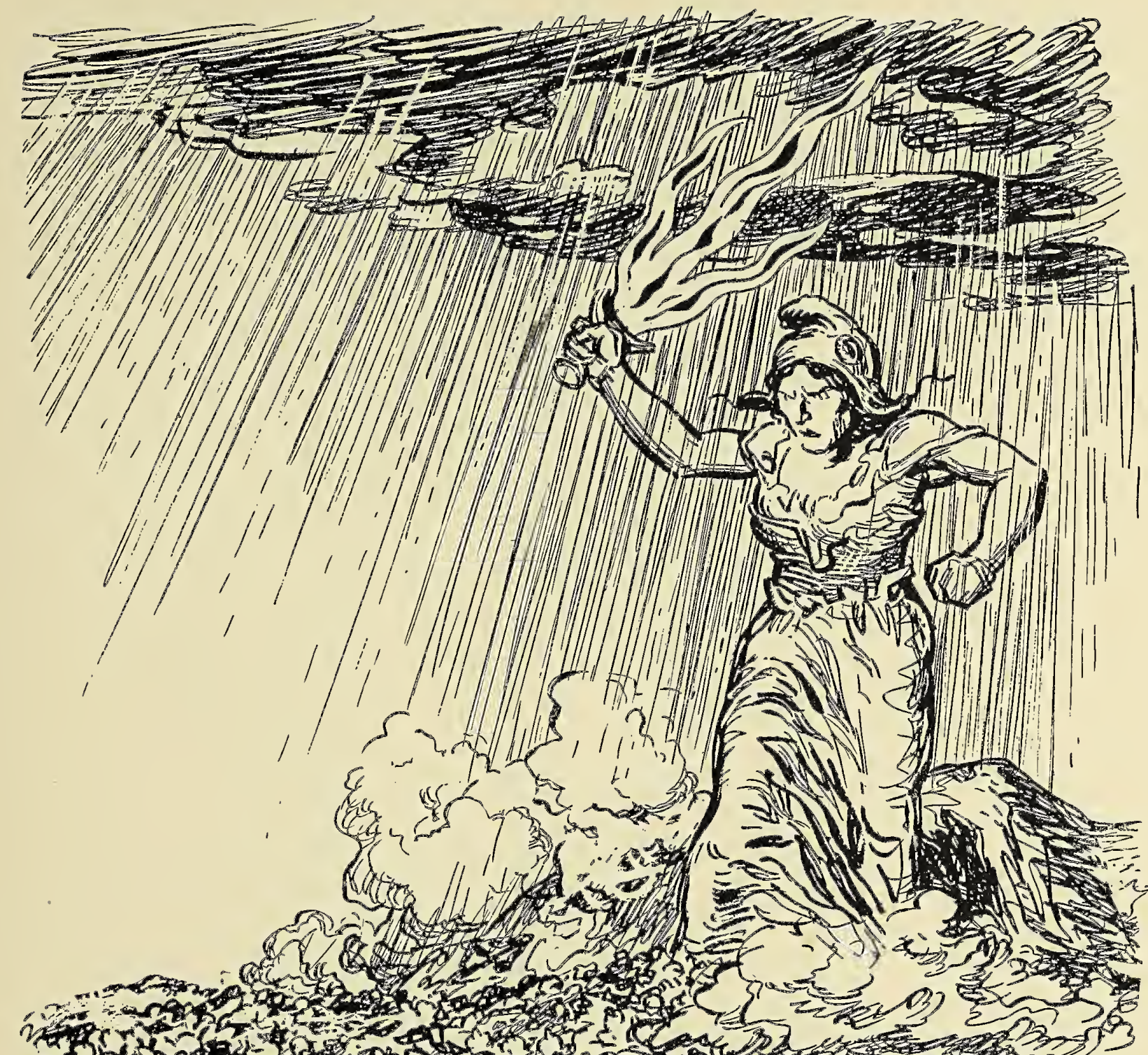

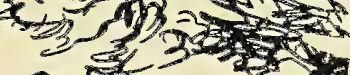

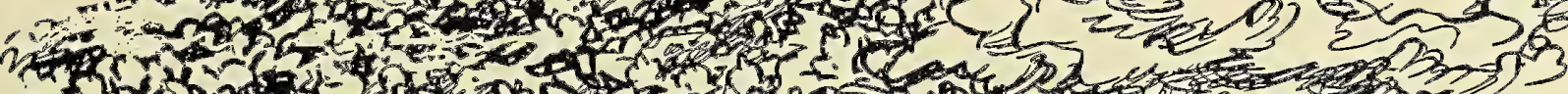
- In

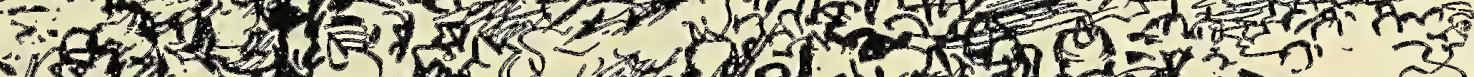

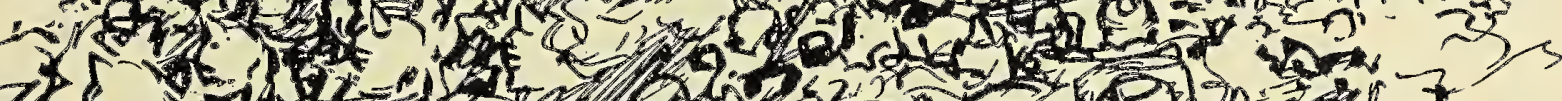

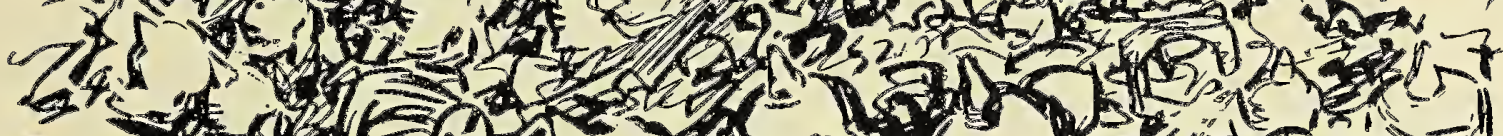
- 4 31

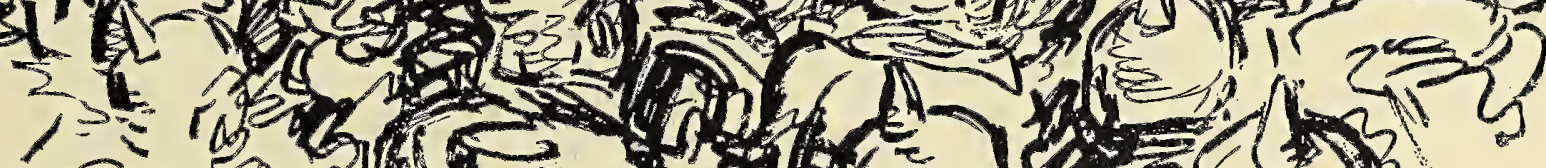
(2)

"LE JOUR DE GLOIRE EST ARRIVË" 



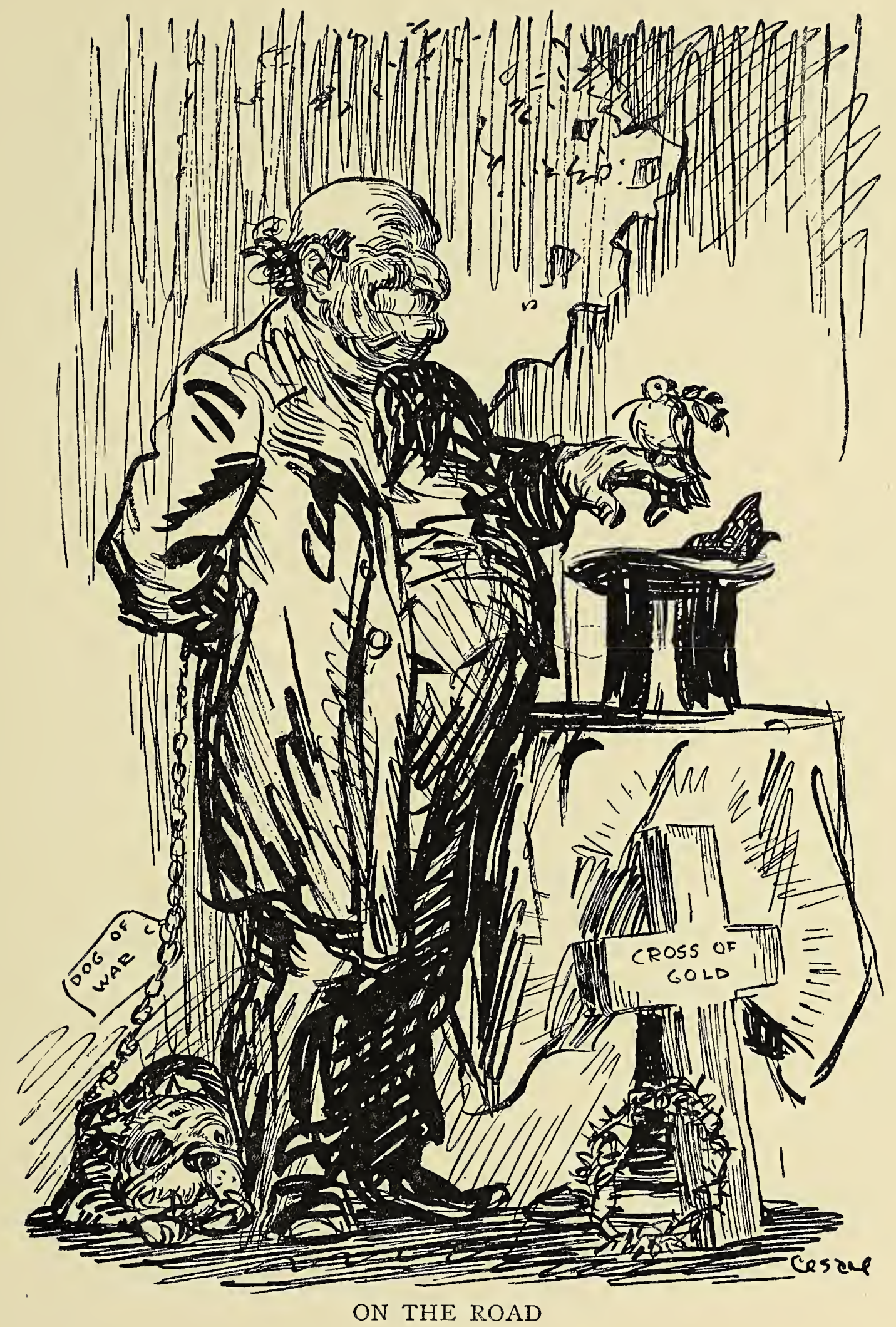

[167] 



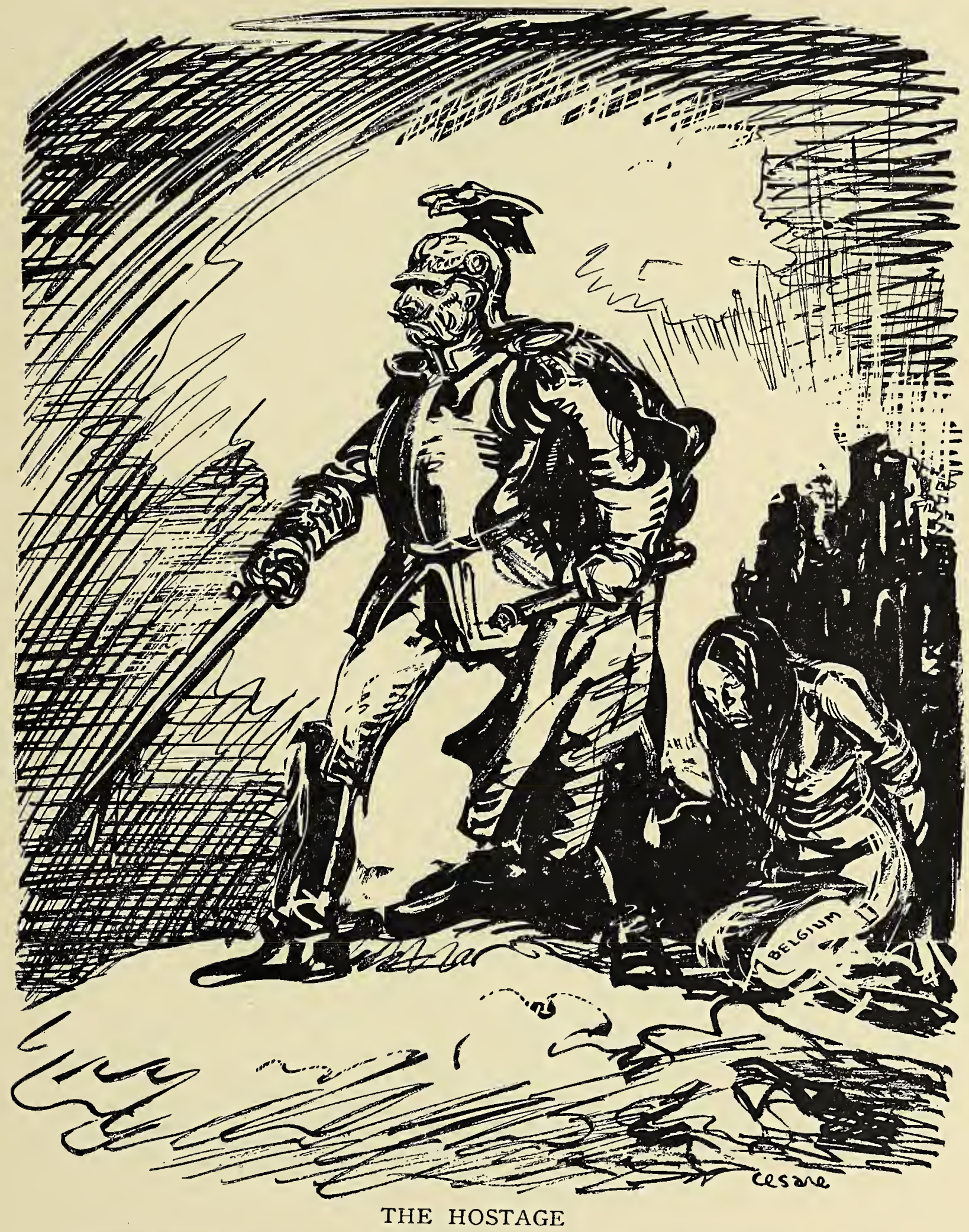

(Germany intends to keep conquered territory until the Allies seek peace. - Cable dispatch, March, 1916)

[169] 



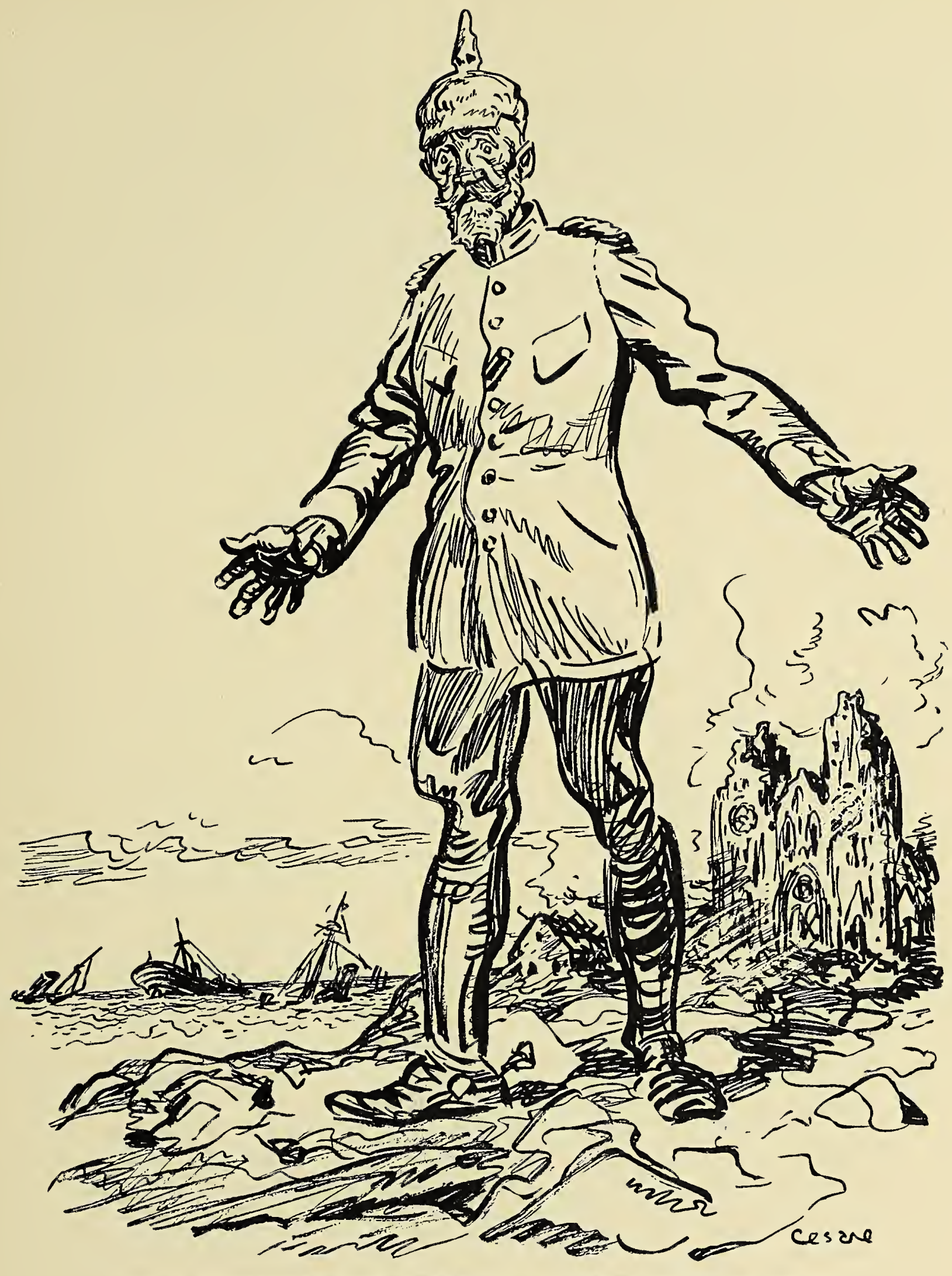

“WHY CONTINUE THE STRUGGLE? CAN'T YOU SEE WE'VE

WON ON SEA AND LAND?"

(Bethmann-Hollweg speaks in the Reichstag, March, 1916) 


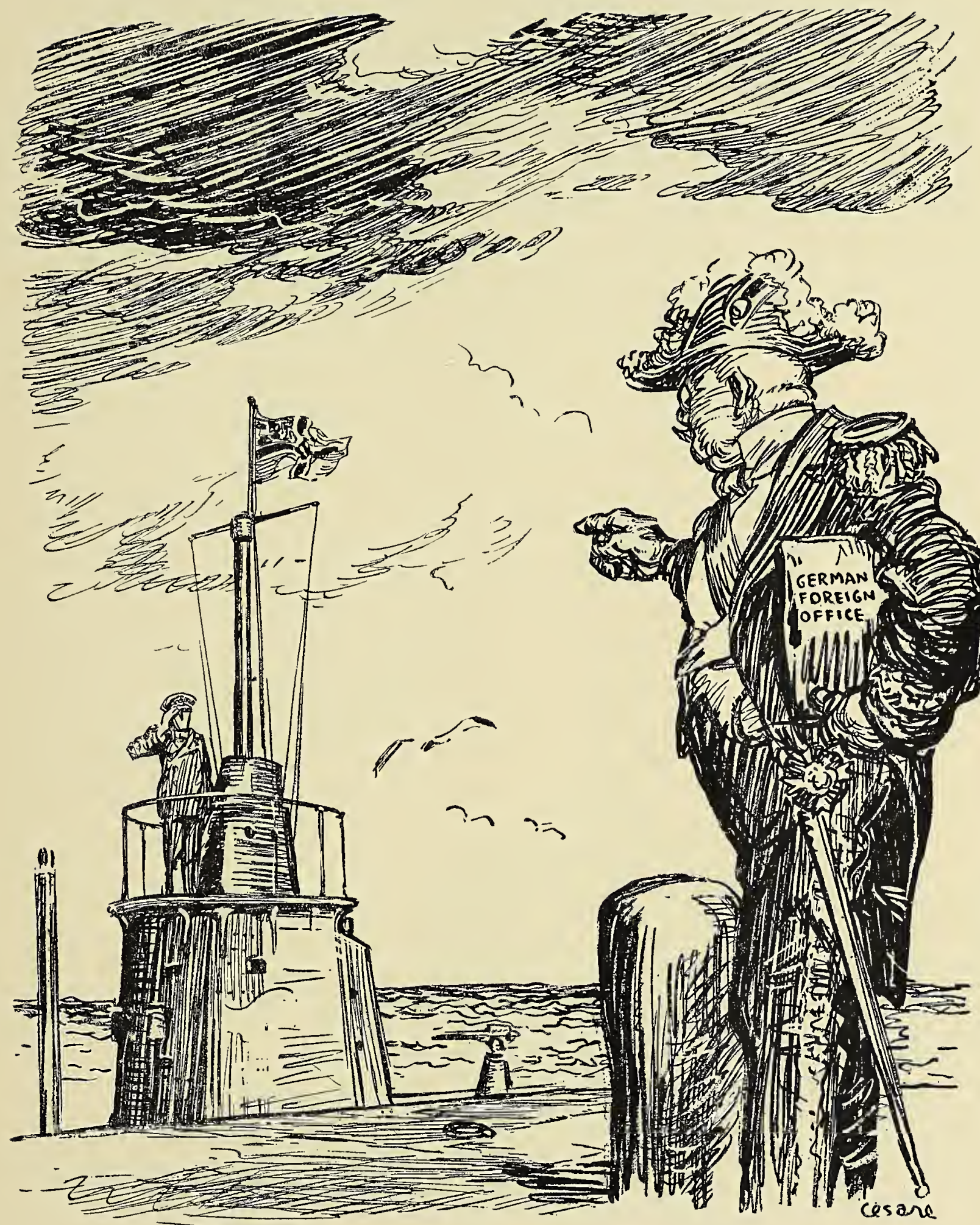

"NOW REMEMBER WHAT I TOLD YOU " 



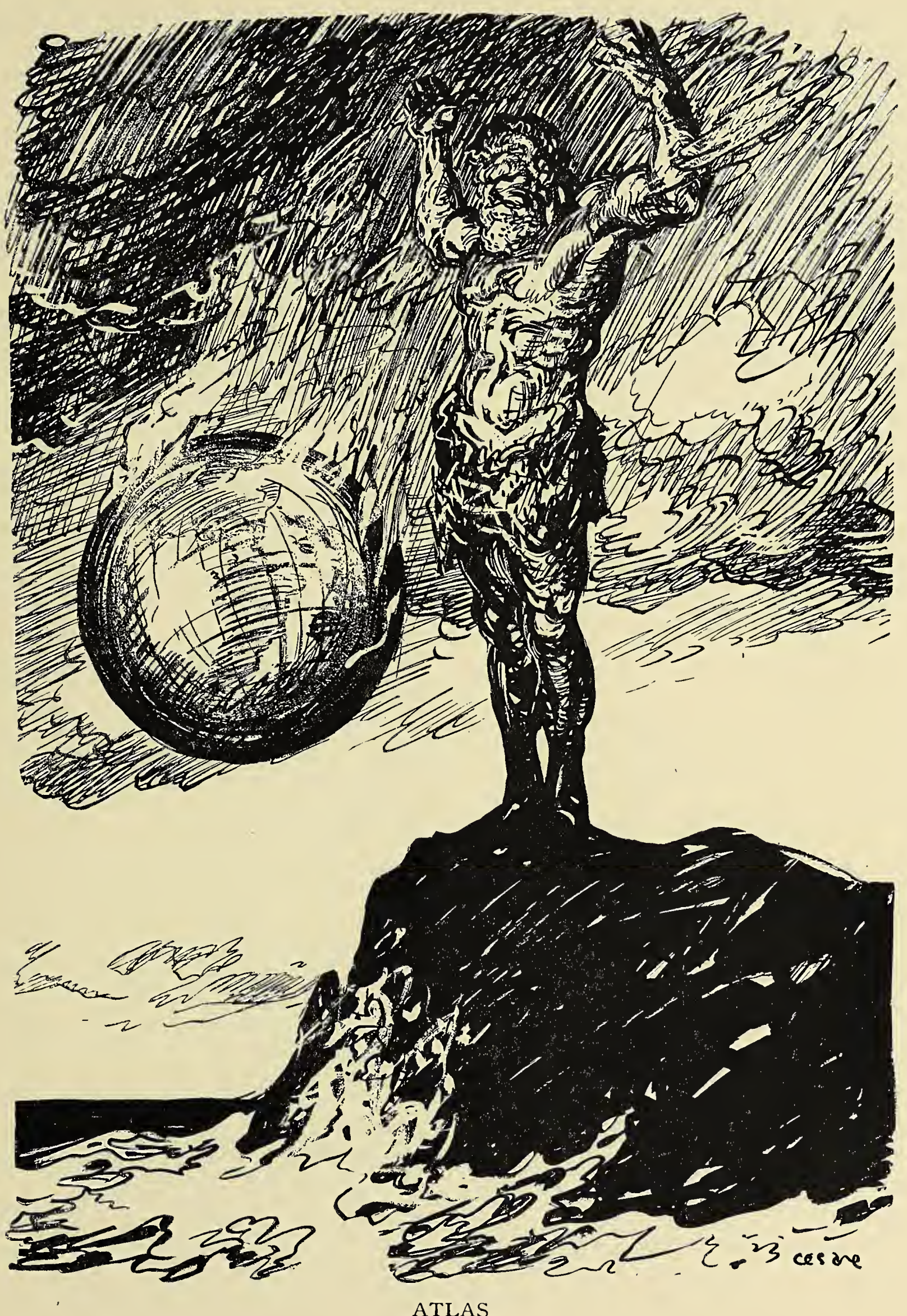

ATLAS

[175] 



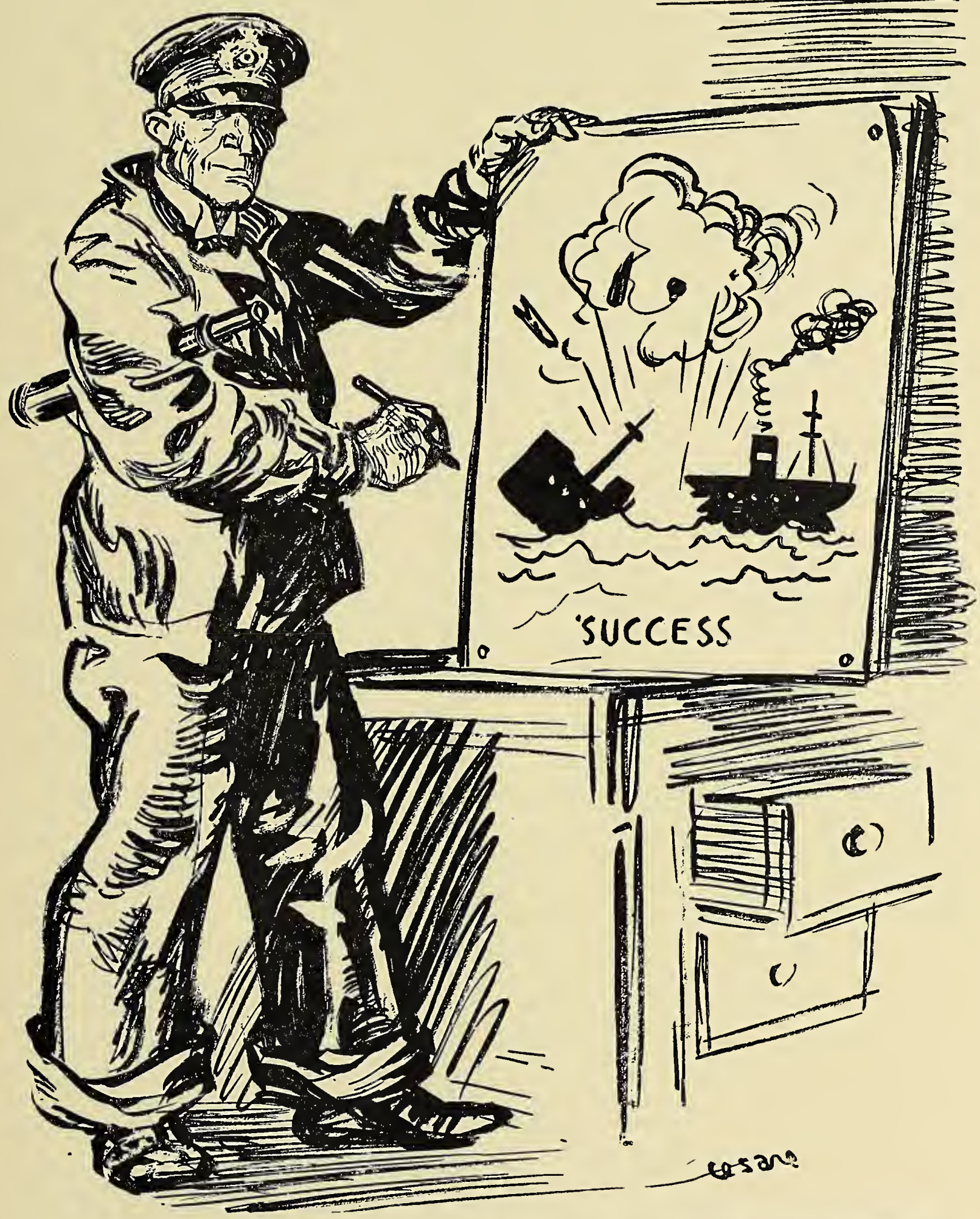

THE GERMAN SUBMARINE COMMANDER'S ACCURATE CONCEPTION OF THE BOAT HE BLEW UP (April 14, 1916) 



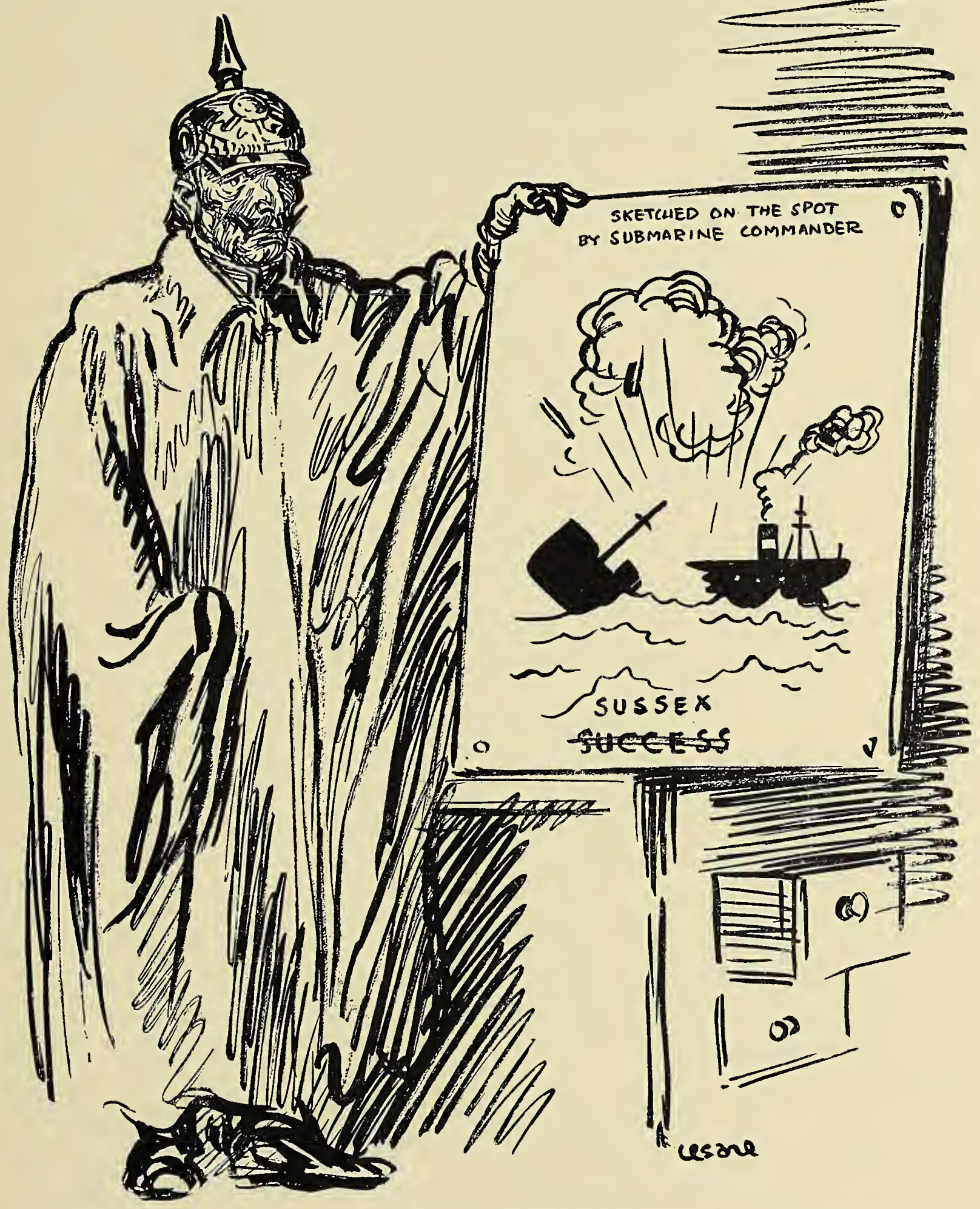

"I CAN NOT TELL A LIE: HE DID IT WITH HIS LITTLE SUBMARINE" 



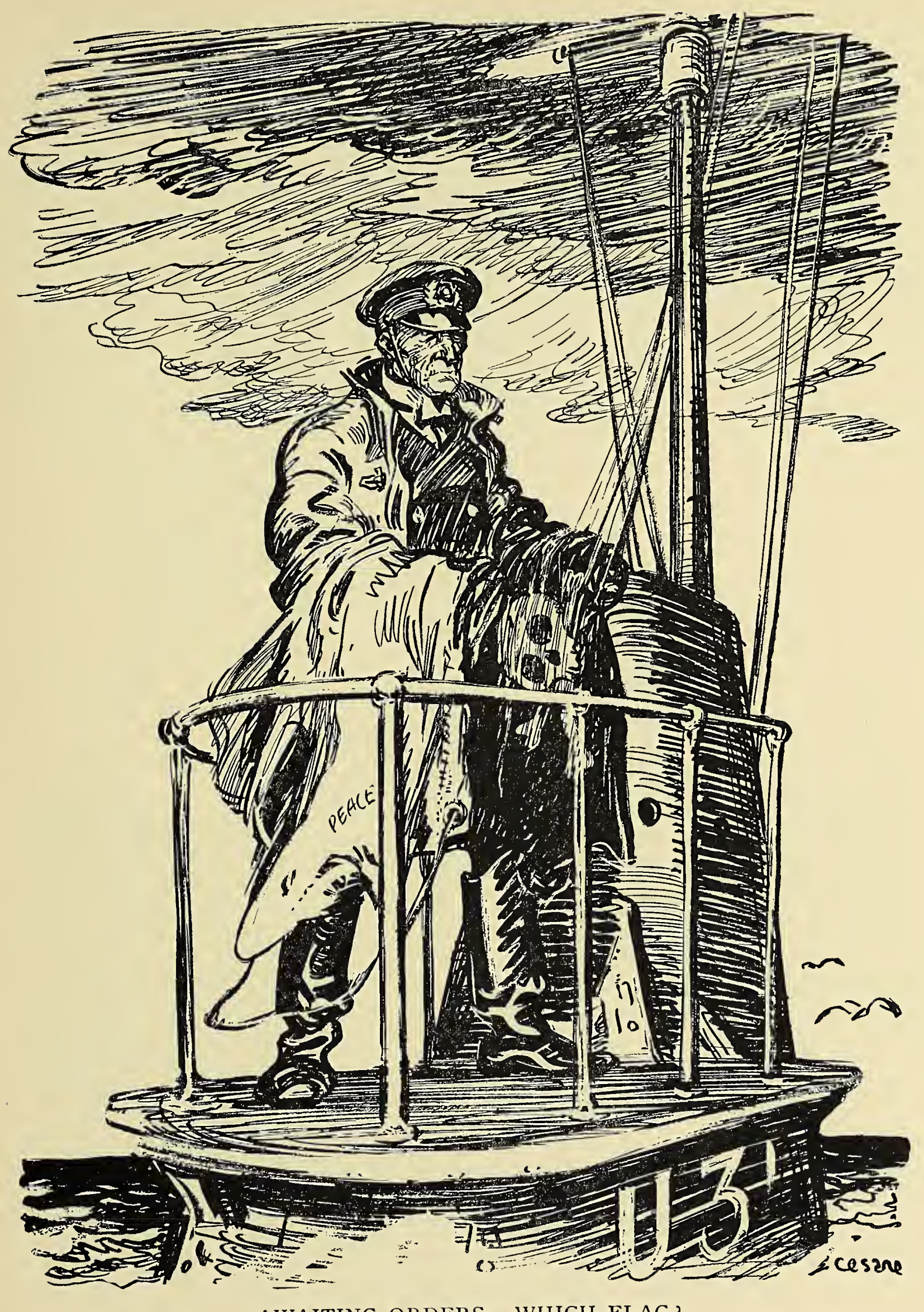

AWAITING ORDERS - WHICH FLAG ?

(April 2I, 1916, before the German reply had been received) 



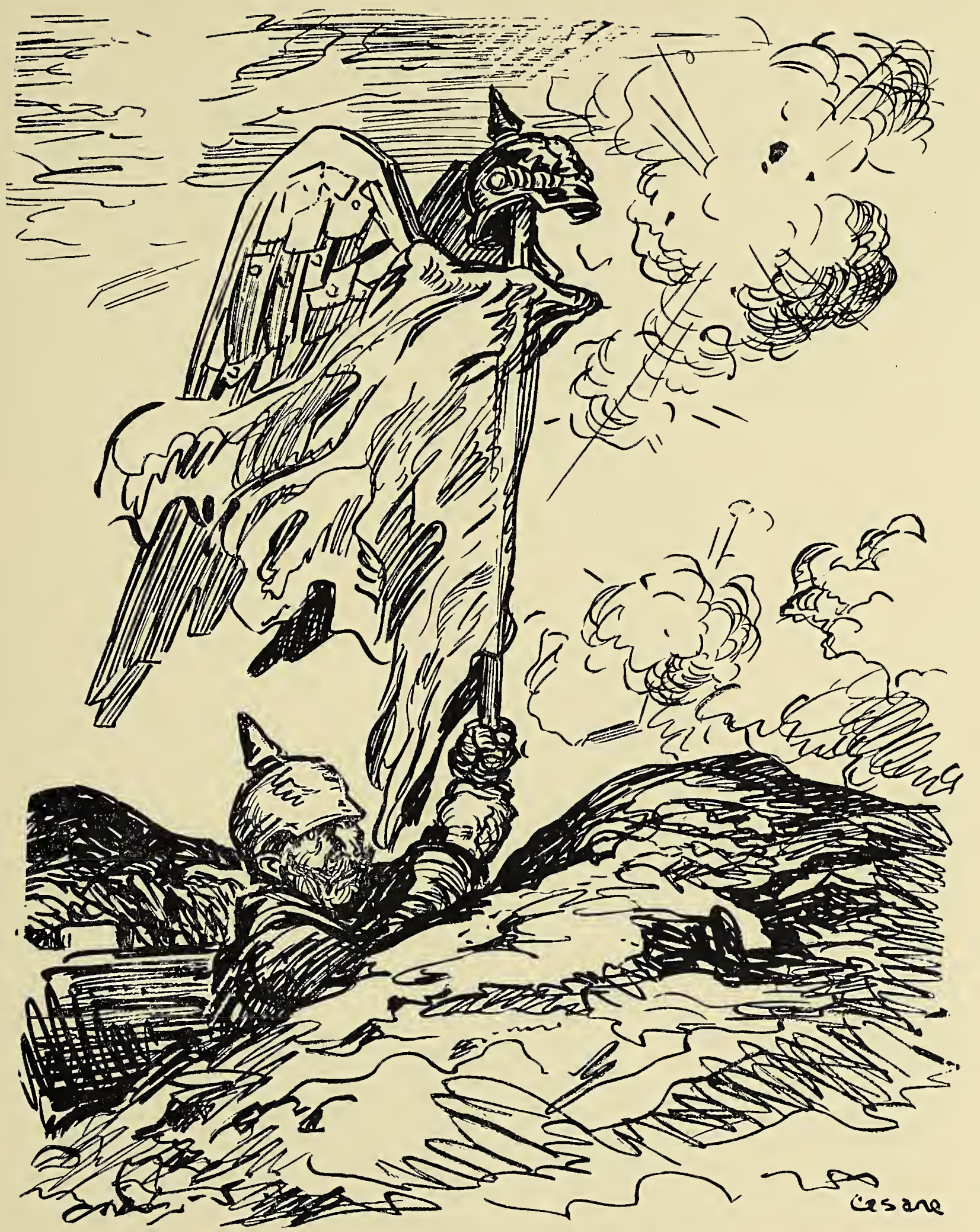

“IT IS NOT GERMANY'S FAULT IF PEACE IS STILL WITHHELD FROM THE NATIONS OF EUROPE"

(From Germany's reply to the American note on the submarine issue, May 8, I9r6) 



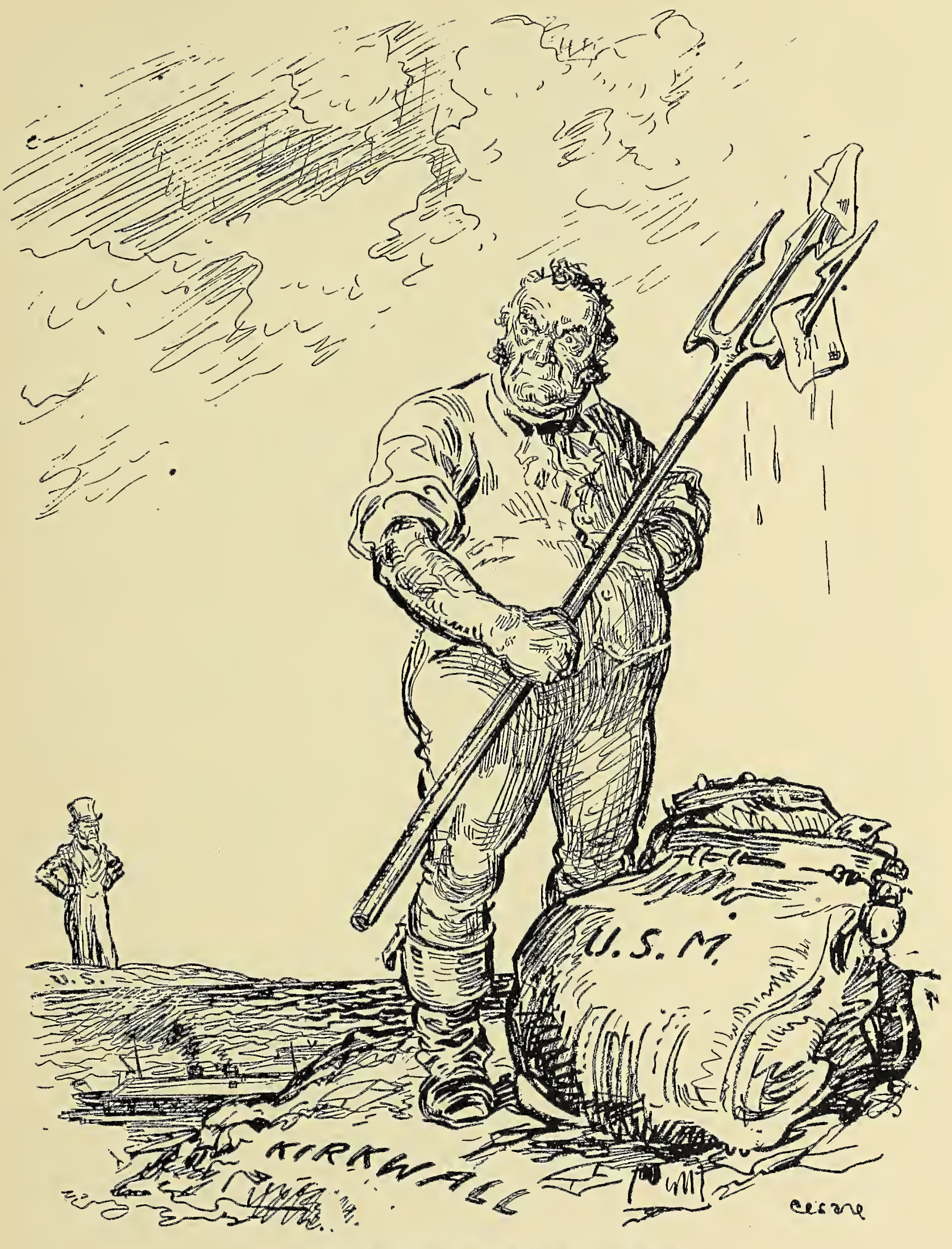

"GO EASY WITH THAT, JOHN!" 



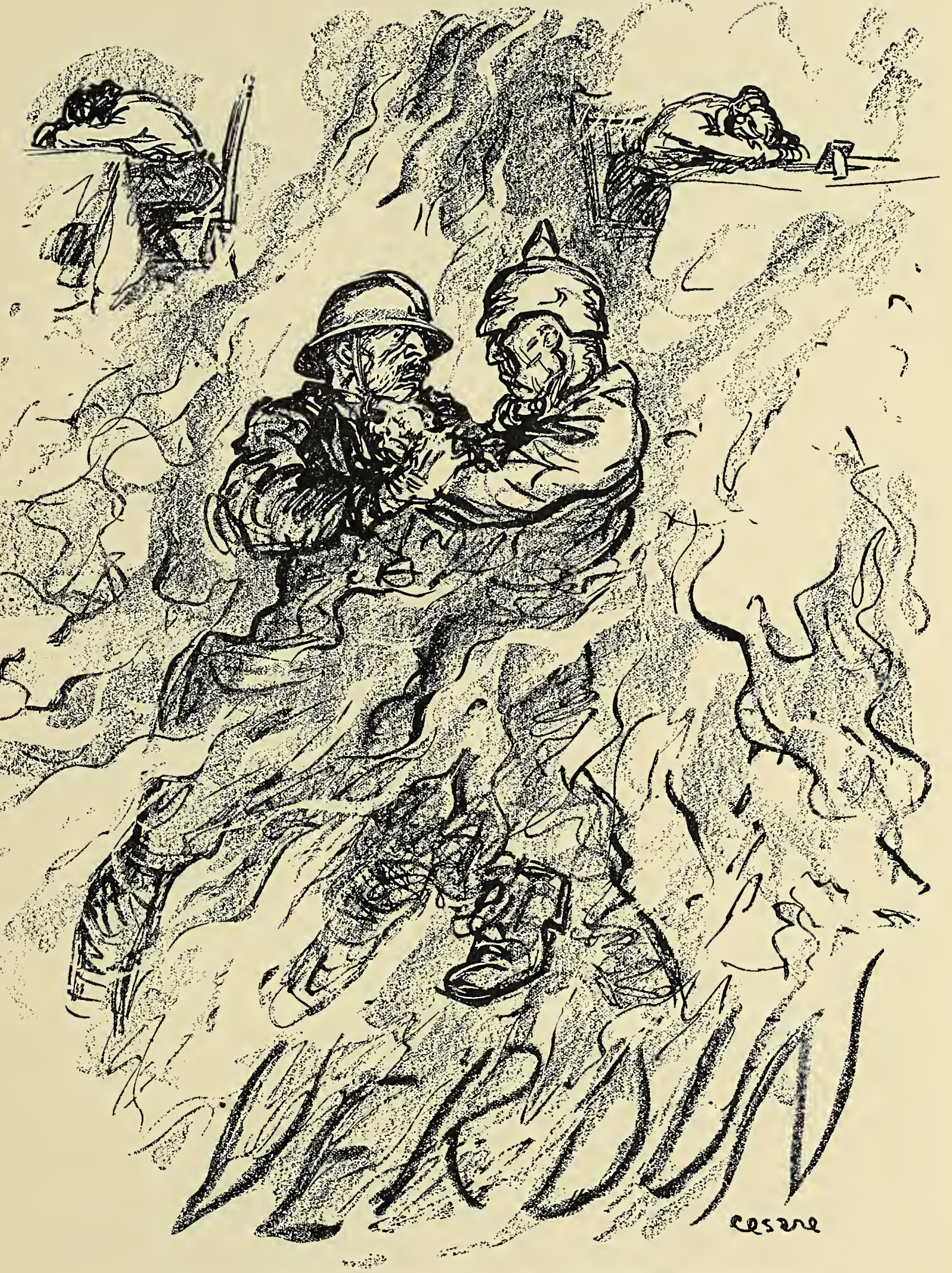

"UNCEASING WAS THE PLAY OF WRETCHED HANDS" 



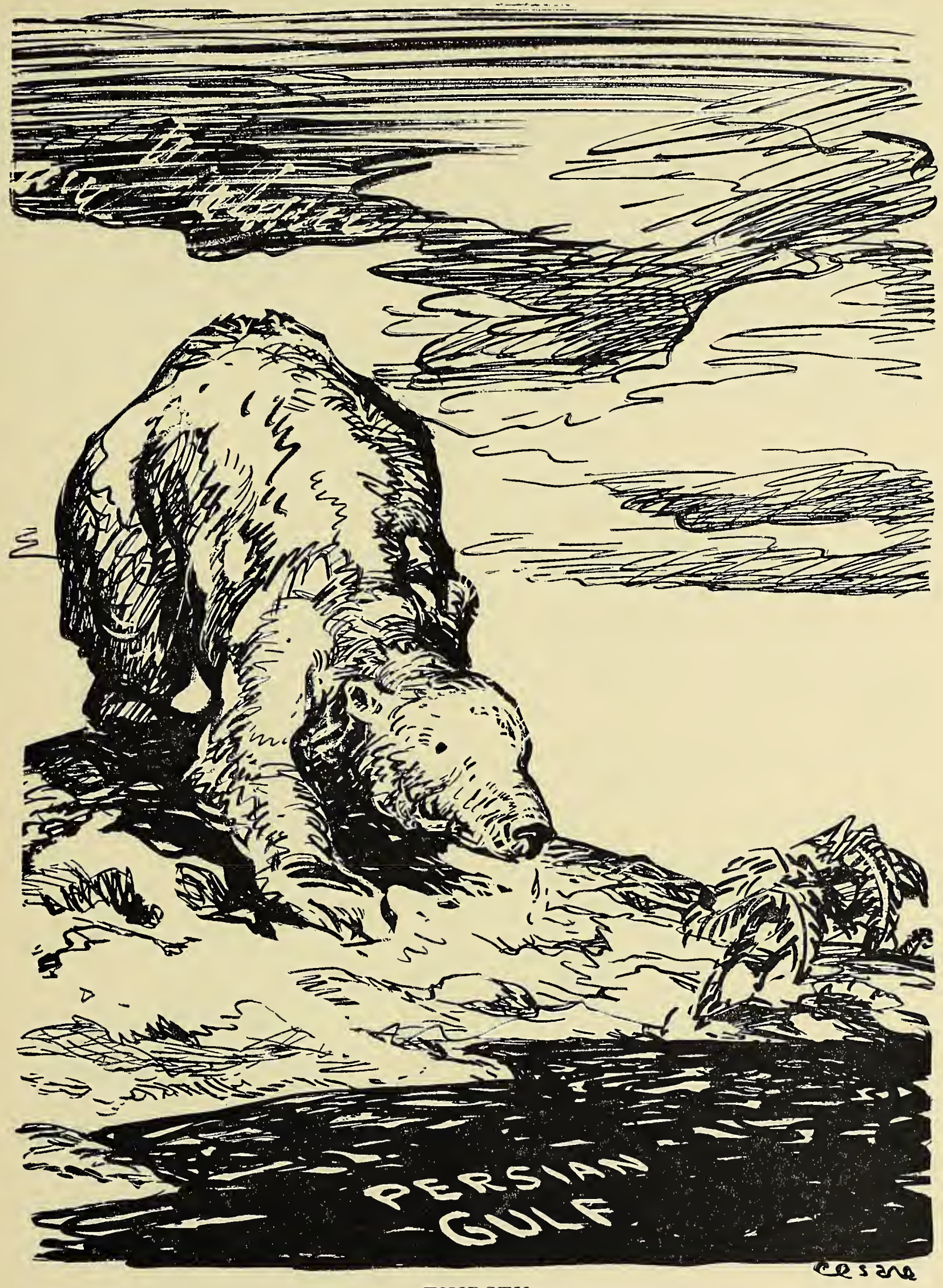

THIRSTY

(May 14, I916. - The British surrender at Kut-el-Amara, while the Russians are moving south) 



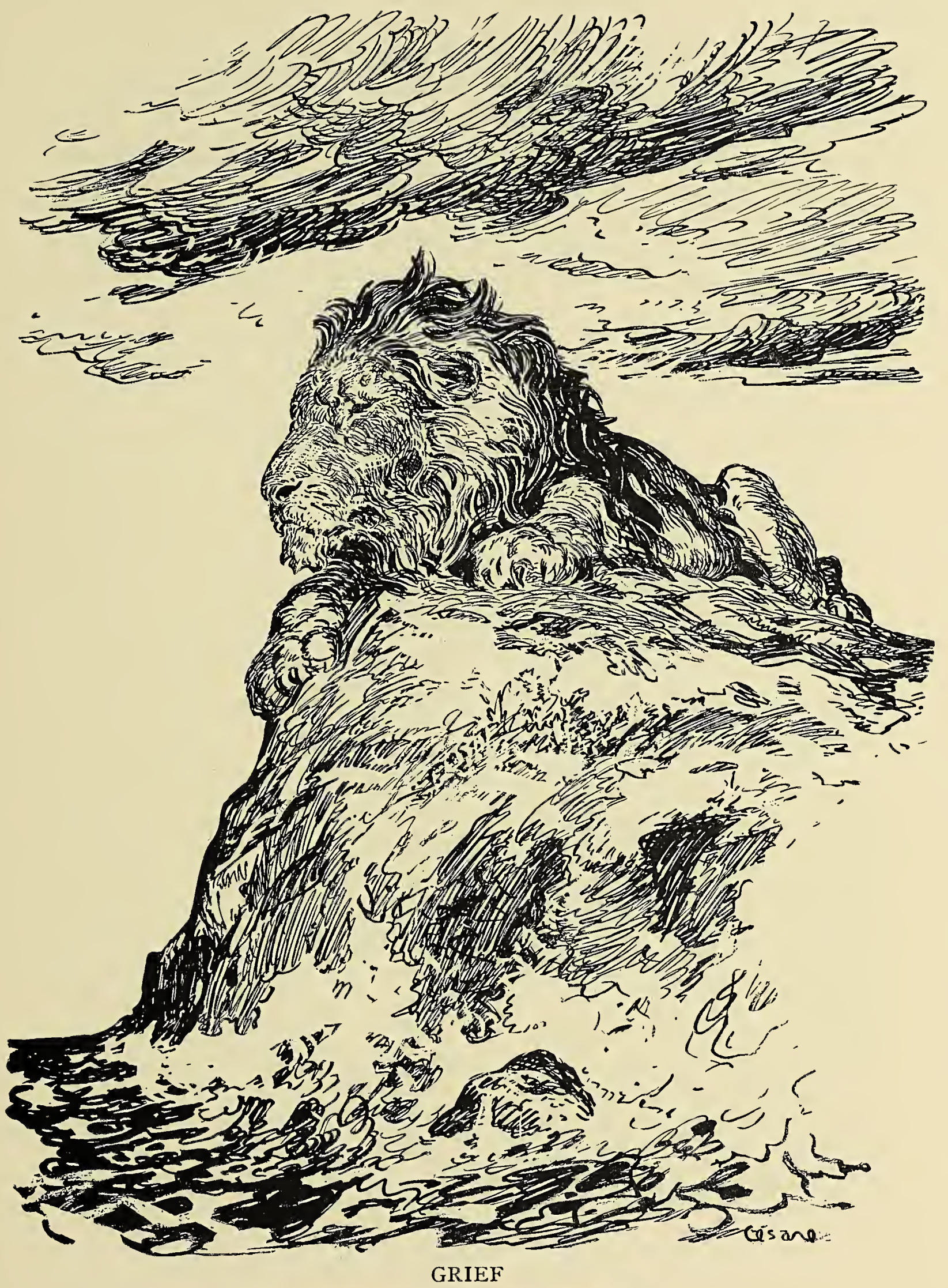

(On the death of Lord Kitchener, June, 1916) 



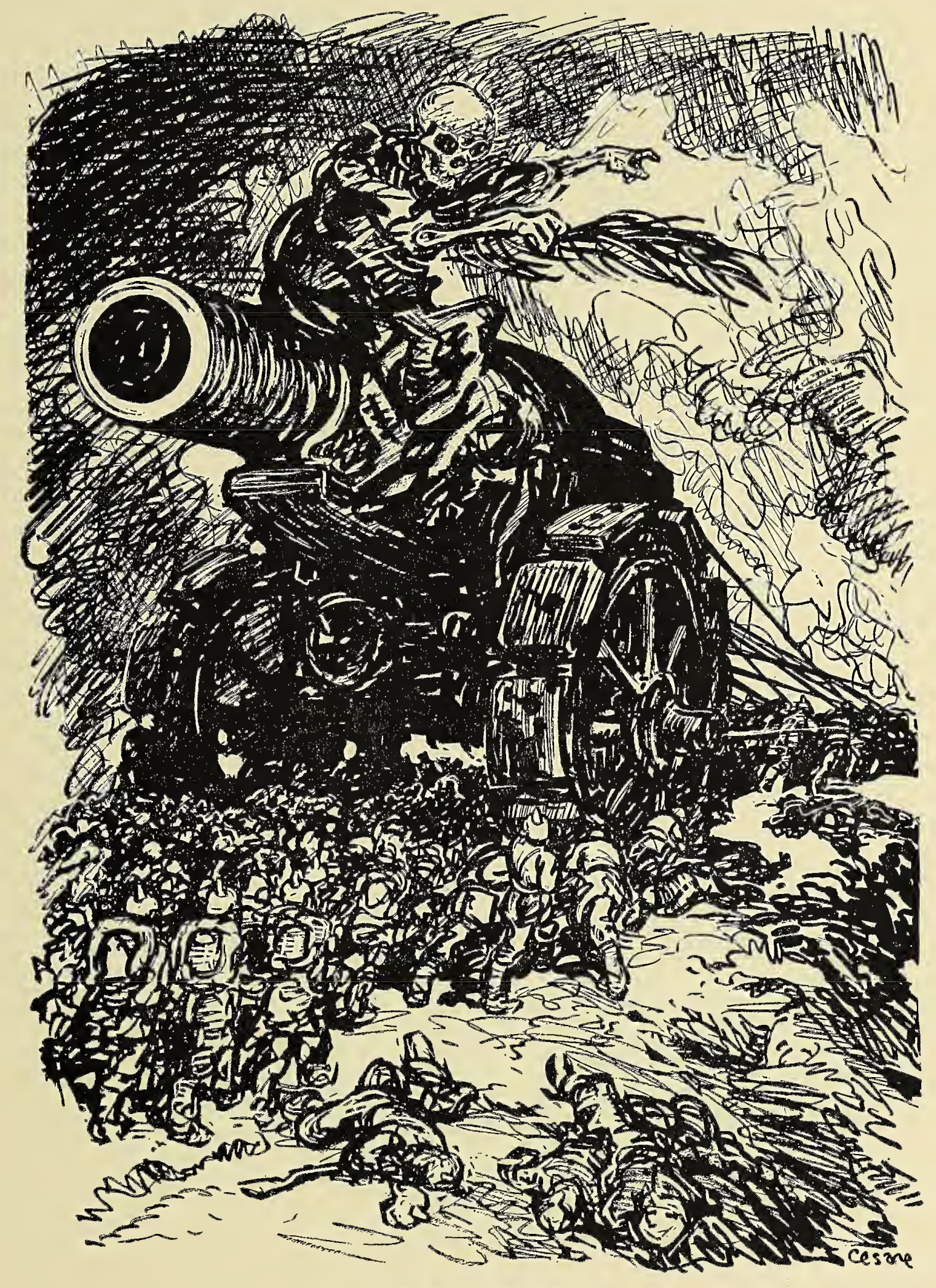

VIA VERDUN 



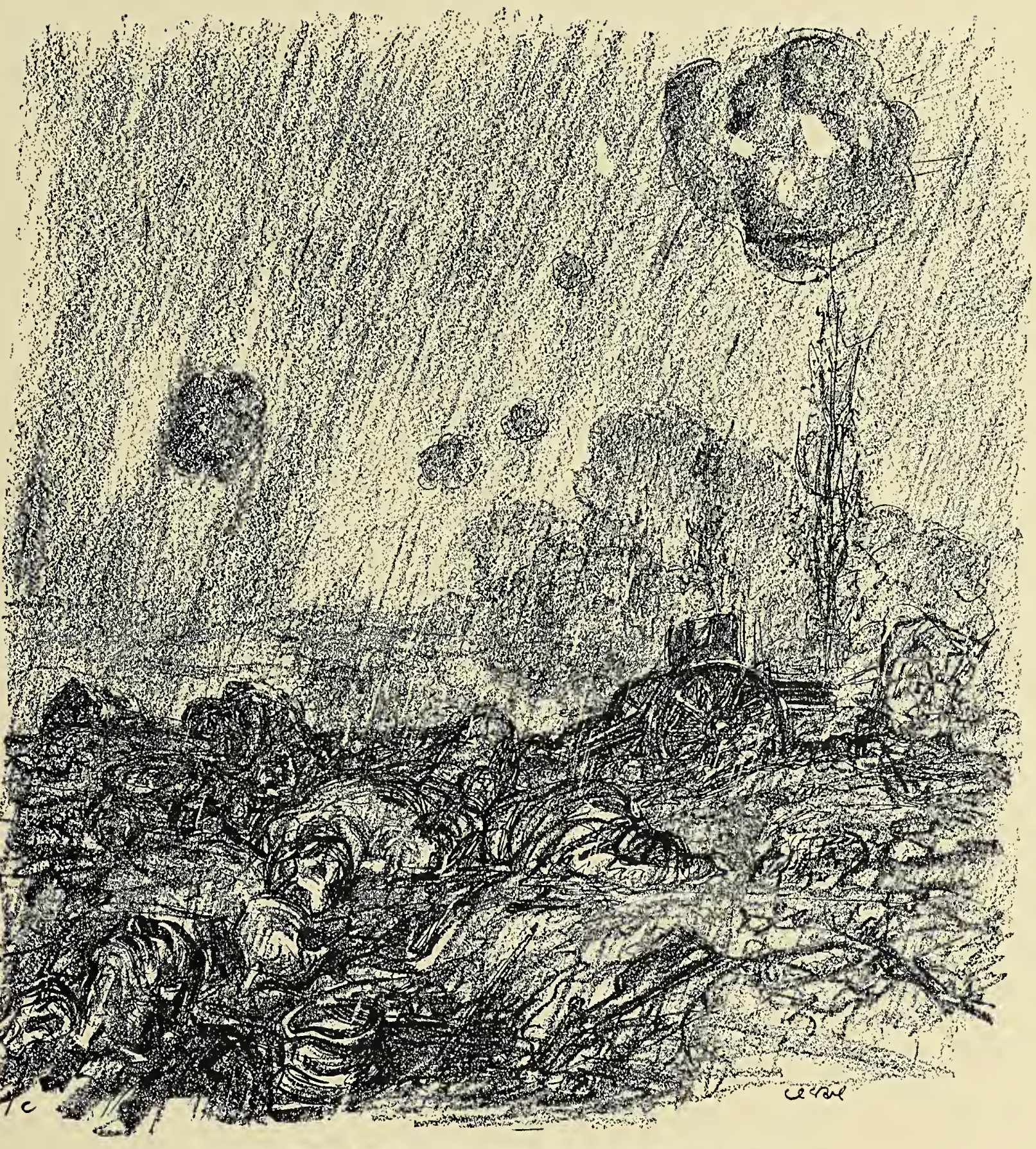

"THE SITUATION CONTINUES SATISFACTORY"

-Official Report

[195] 



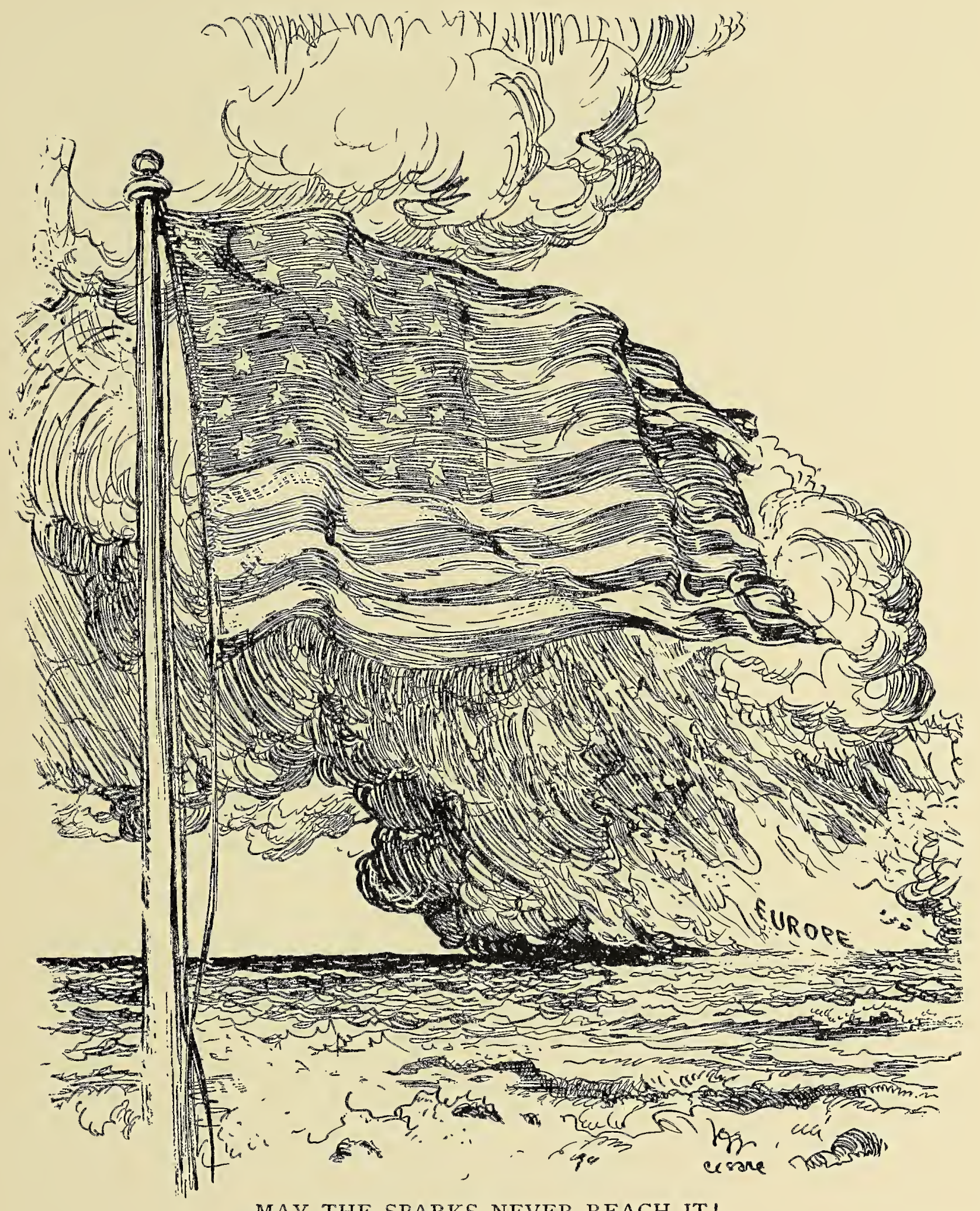

MAY THE SPARKS NEVER REACH IT!

[197] 


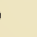




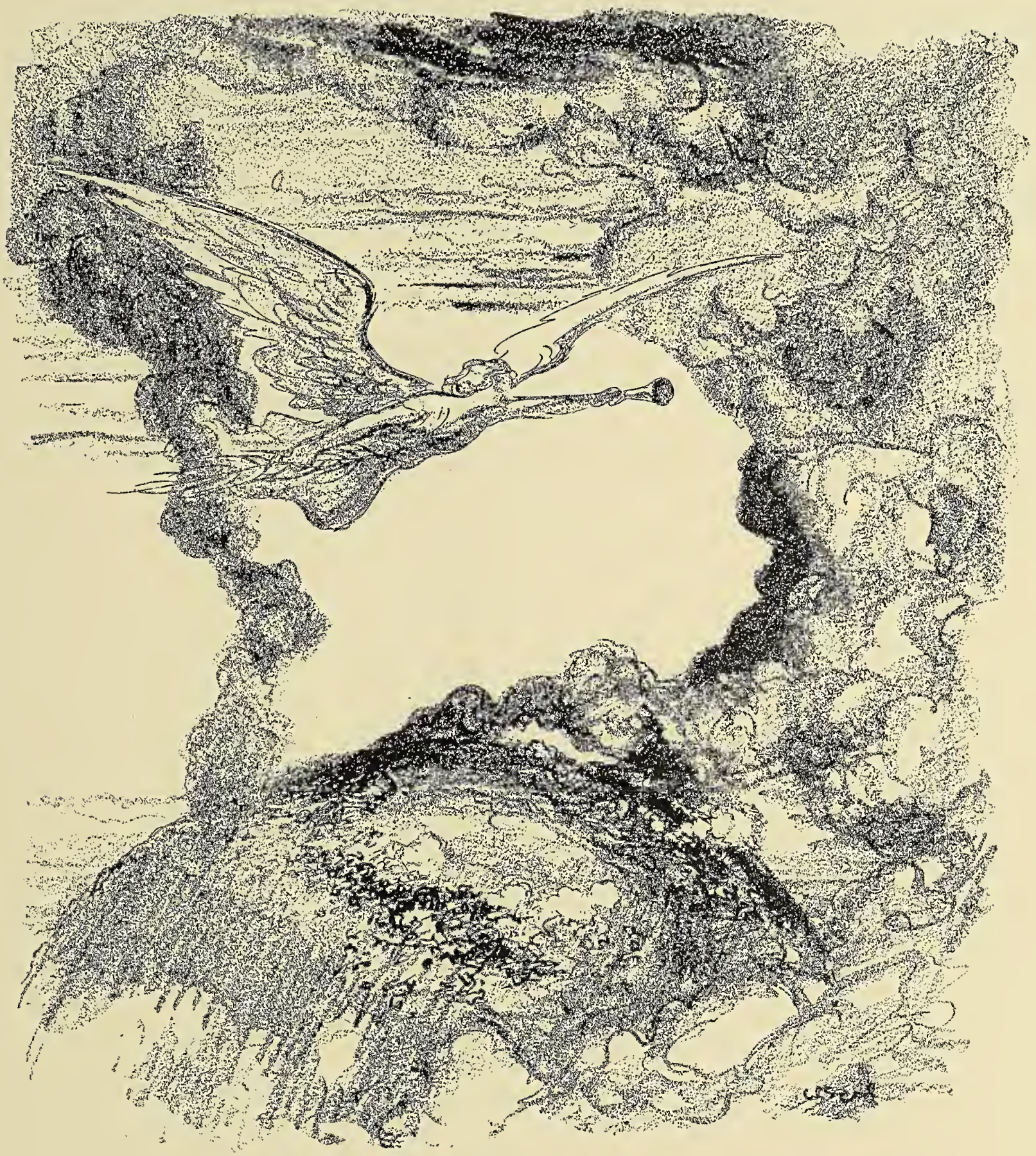

"LET THE BUGLES SOUND THE TRUCE OF GOD TO THE WHOLE WORLD FOREVER!" 




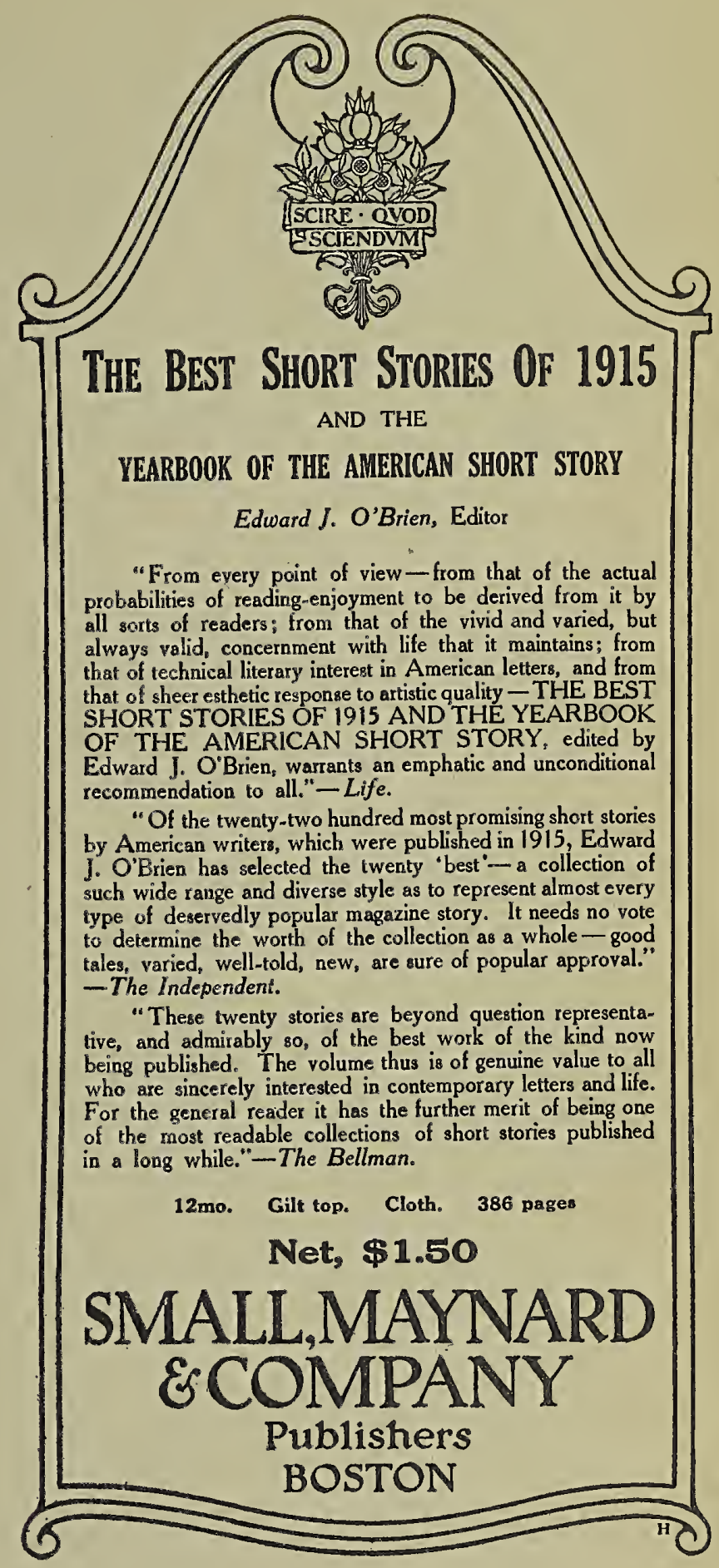




\section{IMPORTANT ART BOOKS \\ Published by SMALL, MAYNARD \& COMPANY ONE HUNDRED CARTOONS BY CESARE \\ Brilliant and powerful interpretations of our times, by the man whose recent change}

from the New York Sun to the New York Evening Post gave the latter newspaper opportunity to congratulate itself on the good fortune which had enabled it, when for the first time in its history it decided to add a cartoonist to its regular staff, to obtain the services of the ablest cartoonist in America. Cesare is more than a cartoonist : he is an artist, and is known as such throughout this country, while his work is reprinted in European periodicals more often than that of any other American cartoonist. His greatness lies in his genius as an artist as well as in the strength of the ideas that his drawings express.

4 to, boards, net, $\$ 3.00$. Also, edition de luxe, printed on Japan vellum, limited to 105 copies, each numbered and signed by the artist, net $\mathbf{\$ 7 . 5 0}$

ART

By Auguste Rodin

Translated from the French of PAdL Gsell by Mrs. RoMrity FedDeN

" A faithful reproduction by Paul Gsell of conversations with Rodin, showing his direct practical attitude towards life and the meaning of art, and repeating his interesting observations and ideas on such special phases as realism, nature, movement, thought and mystery in art. A notable and unique work. Of the 106 beautiful illustrations in halftone and photogravure, 67 reproduce Rodin's work." - AMERICAN Librarx Association Booklist.

8ro. With a frontispiece in photogravure and 105 other illustrations. Buckram net, \$3.50; three-quarter levant, net, $\$ \mathbf{7 . 5 0}$. Also, large-paper edition, with 8 illustrations in photogravure and 98 in half-tone. Buckram, net, $\$ 7.50$; threequarter levant, net, $\$ 15.00$.

JAN VERMEER OF DELFT

By Philip L. Hale

"At last we have a book in English on Vermeer - an extremely valuable, popular account. We get from such a book as this not only an interpretation of a particular artist's art, but also of the art of painting in general. Writing about Vermeer in The Outlook some years ago, Mr. E. V. Lucas called him 'the rarest and most fastidious of masters.' After reading Mr. Hale's book one feels anew the justice of that statement." - Outlook.

"The most elaborate stylistic analysis ever applied to any artist." - Nation.

Large 8vo. With reproductions in color, in photogravure and in half-tone of all of Vermeer's known works, together with examples of the work of some of his contemporaries. Buckram, net, $\$ \mathbf{1 0 . 0 0}$; three-quarter levant, net, $\$ 20.00$.

\section{LEONARDO DA VINCI}

By Jens Thiis

"A beautiful and original book which deserves the extravagant praise that it is worthy of its subject. The most vital of recent contributions to the comprehension of Leonardo. It is a magnificent collection of great pictures and drawings, for not only Leonardo but all his contemporaries are exquisitely represented in it." - Pall Mall Gazette (London).

Large 4to. With 277 illustrations reproduced in tints and in black and white. Edition limited to 250 copies. Buckram, net, $\$ \mathbf{1 2 . 0 0}$; three-quarter levant, net, $\$ 24.00$. CHURCH BUILDING (New and En?arged Edition)

By Ralph Adams Cram

A standard volume by one of the leading American architects, the head of the department of architecture in the Massachusetts Institute of Technology, setting forth the principles of architecture in their relation to the church. 8vo. Cloth. Illustrated. Net, $\$ 3.00$. LELY AND THE STUART PORTRAIT PAINTERS $A$ Study of English Portraiture Before and After Van Dyck.

By C. H. Collins Baker

More than a hundred collections, including the finest private galleries of England, were, by the courtesy of their owners, made available for the study which the author gave to the preparation of this extraordinary work, which covers English portraiture (omitting Van Dyck because he has already been so frequently studied) from 1603 to 1723 , or from Holbein to Hogarth.

Two volumes. Large Crown 4to. With 240 illustrations, of which eight are in color and the others in collotype. Of the edition of 375 numbered copies ( 350 only for sale) printed on special rag paper for the Medici Society, of London, 50 are reborved for the United States. Three quarter levant. Fer set, net, $\$ 60.00$. 